3. From: (Originating Organization) Characterization Support

5. Proj./Prog./Dept./Div.: WM/Characterization

6. Cog. Engr.:

B. C. Simpson

\section{Originator Remarks:}

Tank Characterization Report for Single-Shel1 Tank 241-C110. This report contributes to the fulfillment of TPA Milestone M-44-05

11. Receiver Remarks:

\section{RE@EDED OCT 034994 0.67}

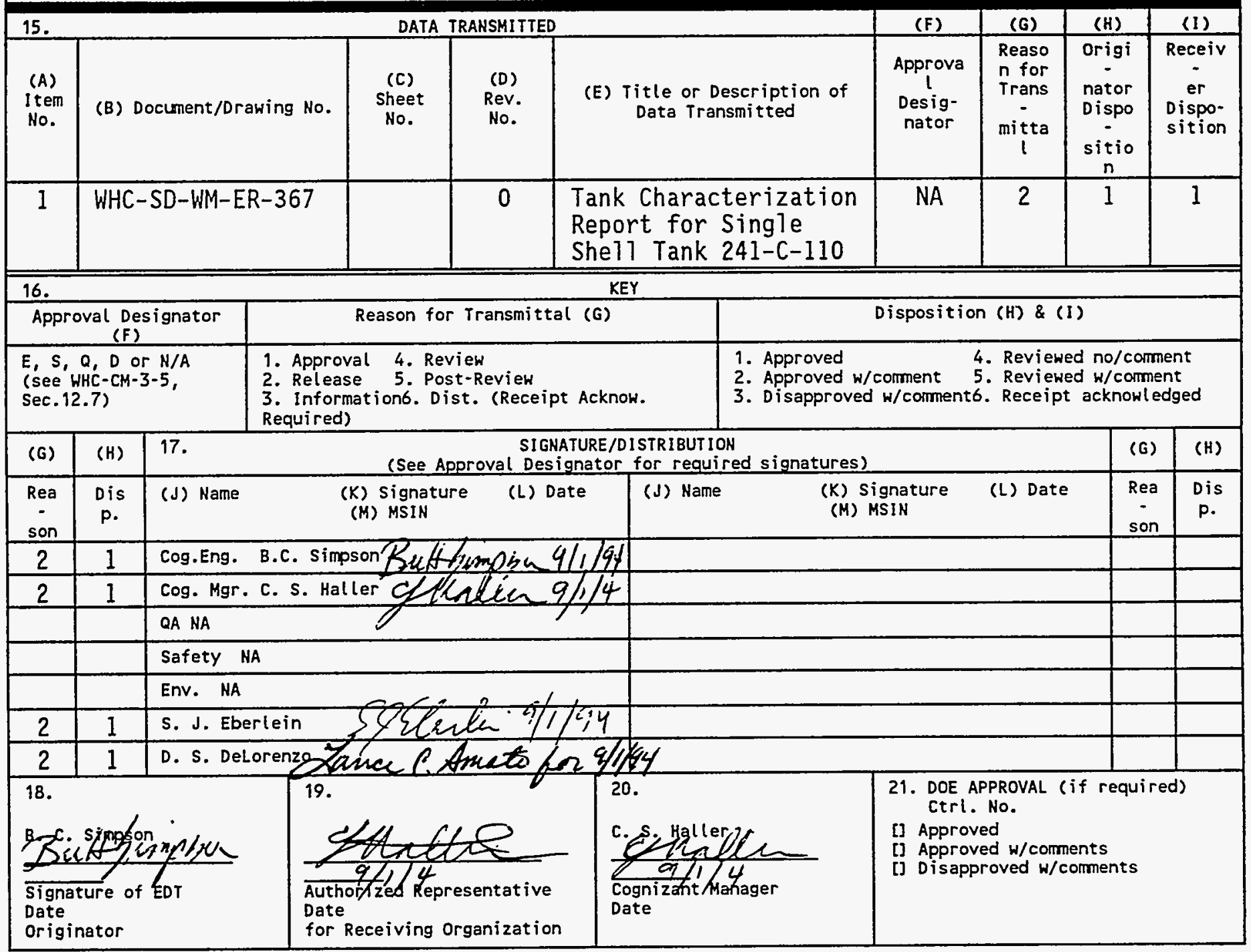

BD-7400-172-2 (04/94) GEF097

4. Related EDT No.:
7. Purchase Order No.:
NA

9. Equip./Component No.: NA

10. System/Bldg./facility: Tank Farms

12. Major Assm. Dwg. No.: NA

13. Permit/Permit Application No.: NA

14. Required Response Date: Sept. 6, 1994 


\section{DISCLAIMER}

Portions of this document may be illegible in electronic image products. Images are produced from the best available original document. 


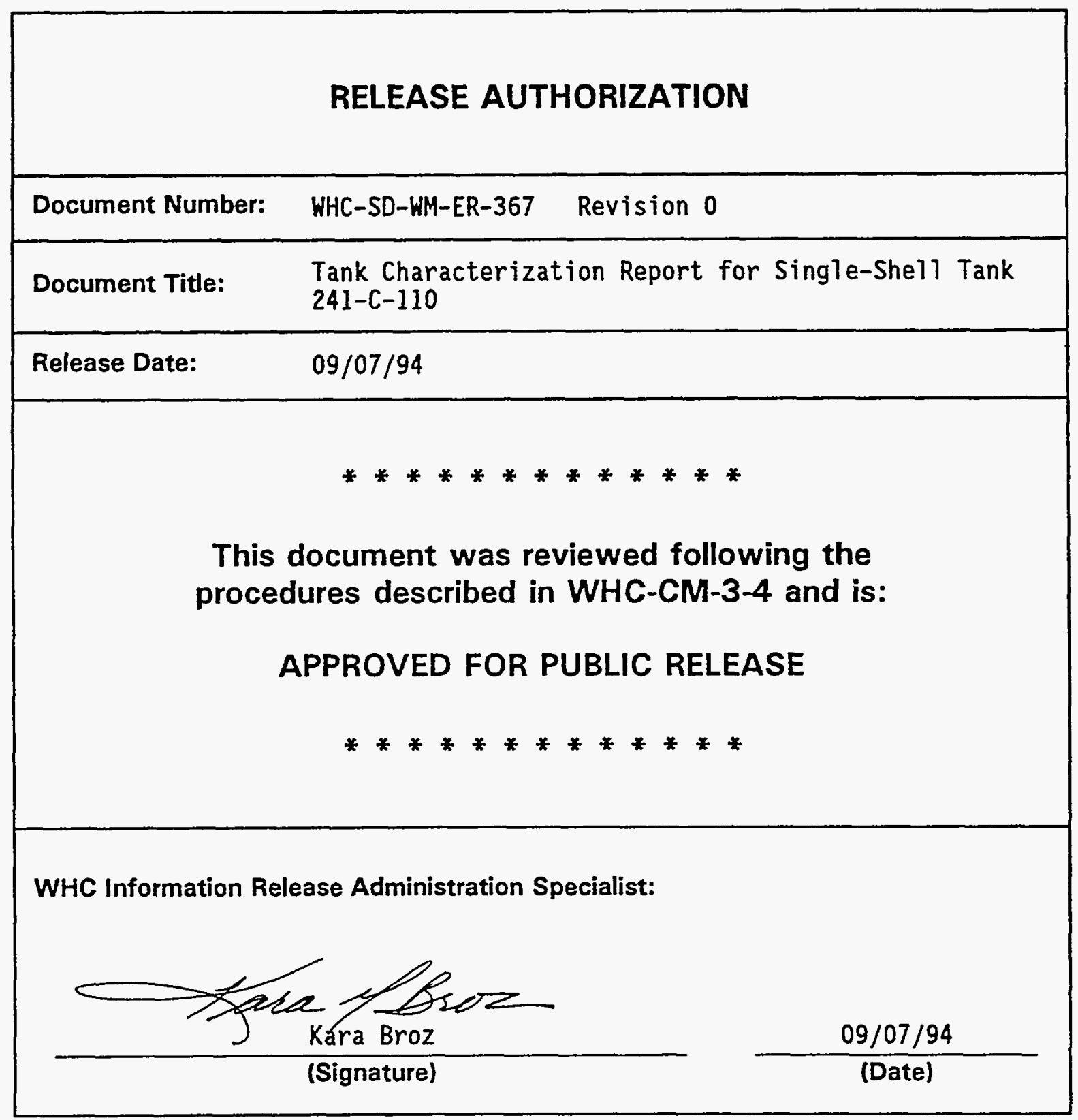


2. Title

Tank Characterization Report for Single-Shell Tank $241-C-110$

5. Key Words

Waste Characterization; Single-She 17 Tank; C-110;

Tank Characterization Report; Waste Inventory; $C$

Farm; TPA Milestone M-10; TPA Milestone M-44

3. Number

4. Rev No.

WHC-SD-WM-ER-367

0

6. Author

Name: D.S. DeLorenzo

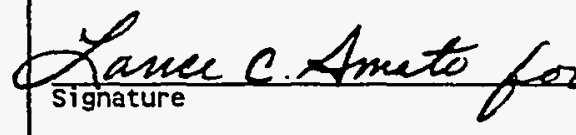

Name: B.C. Simpson

\section{APPROVED FOR}

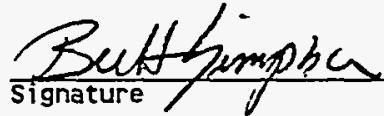

PUBLIC RELEASE

Organization/Charge code 7E720/N4D2F

7. Abstract

This document provides the characterization information and interprets the data for Single-She 17 Tank $\mathrm{C}-110$

8. PUARRese and USE OF DOCUMENT - This document was prepared for use with in the U.S. Department of Energy and its contractors It is to be used onk to perform, direct, or integrato work under U.S. Department ox Energy contracts. This documont is not approved for public release untiv reviewed.

PATENT STATUS - This document oen, since it is transmitted in advance of patent clearance is made axailable in confidence solely for use in performaper of work undex contracts with the U.S. Department of Energy. This document is not te be published nor its contents otherwise disseminated or used for purposes other than specified otbove before patent approval for such release on use has been otcured, upon request, from the Patent Counsel, U.S. Departmont of Energy field office, Richland, HA.

DISCLAIMER - This report was prepared as an account of work sponsored by an agency of the United States Government. Neither the United States Government nor any agency thereof, nor any of their employees, nor any of their contractors, subcontractors or their employees, makes any warranty, express or implied, or assumes any legal liability or responsibility for the accuracy, completeness, or any third party's use or the results of such use of any information, apparatus, product, or process disclosed, or represents that its use would not infringe privately owned rights. Reference herein to any specific commercial product, process, or service by trade name, trademark, manufacturer, or otherwise, does not necessarily constitute or imply its endorsement, recormendation, or favoring by the United States Government or any agency thereof or its contractors or subcontractors. The views and opinions of authors expressed herein do not necessarily state or reflect those of the United States Goverment or any agency thereof.

9. Impact Level NA

10.

RELEASE STAMP

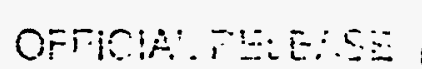

BY' i: dto. 4 


\title{
Tank Characterization Report for Single-Shell Tank 241-C-110
}

\author{
L. C. Amato \\ G. L. Nuttall \\ K. W. Johnson \\ R. W. Lambie \\ A. T. DiCenso \\ Los Alamos Technical Associates, Incorporated
}

R. D. Schreiber

B. C. Simpson

Westinghouse Hanford Company

Date Published

August 1994

Prepared for Westinghouse Hanford Company by

Los Alamos Technical Associates

8633 Gage Blvd.

Kennewick, WA 99336

LATA-TCR-9407, Rev. 0 


\section{EXECUTIVE SUMMARY}

Single-Shell Tank $241-\mathrm{C}-110$ is an underground storage tank containing radioactive waste most recently sampled in April of 1992. Sampling and characterization of the waste in Tank 241-C-110 contributes toward the fulfillment of Milestone M-44-05 of the Hanford Federal Facility Agreement and Consent Order.

Tank 241-C-110, located in the 200 East Area C Tank Farm, was constructed in 1944 and 1945 and went into service in 1946, receiving first cycle decontamination waste from the $B$ and $T$ Plants. Later sources of waste included $U$ Plant, PUREX Plant, Tank 241-BY-104, and Tank 241-BX103. Tank $241-C-110$ is the first tank in a cascade with Tanks 241-C-111 and 241-C-112. The final disposal of the waste in Tank 241-C-110 eventually will be as high-and low-level glass fractions. The tank has an operational capacity of 530,000 gallons, and currently contains 187,000 gallons of dilute complexed waste, existing primarily as sludge. Approximately 7,000

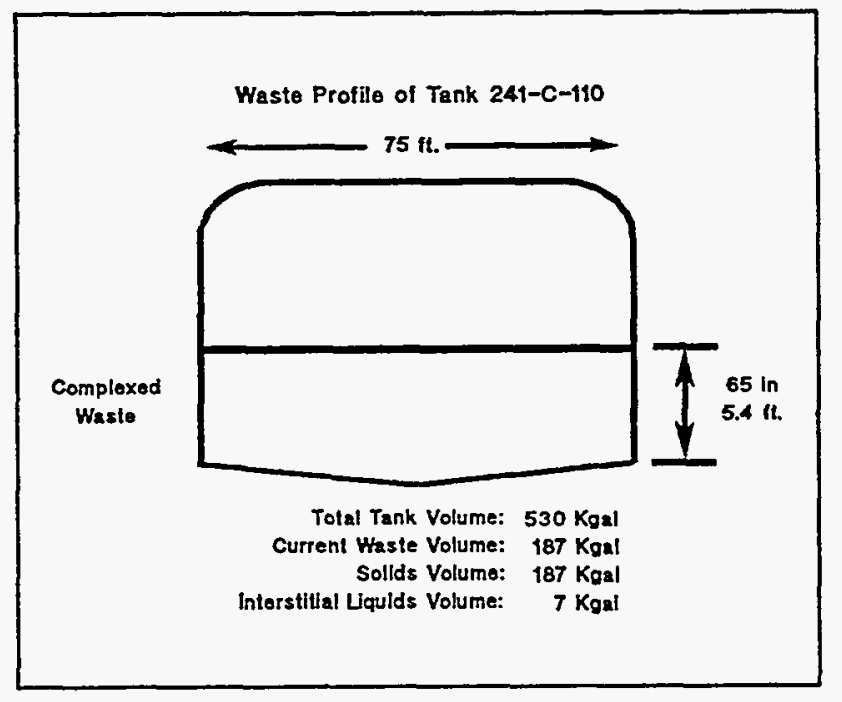
gallons of drainable interstitial liquid remain.

The waste is believed to be heterogeneous, although distinct layers were unable to be discerned. The tank is not classified as a Watch List tank; however, it is an Assumed Leaker, with a leak estimate of 2,000 gallons of waste. The tank was interim stabilized in 1979 and partially interim isolated in 1982. There are no Unreviewed Safety Questions associated with Tank $241-\mathrm{C}-110$ at this time.

The waste in Tank $241-\mathrm{C}-110$ is composed of precipitated salts. The most prevalent analytes include aluminum, bismuth, sodium, iron, nitrate, nitrite, phosphate, and sulfate. The waste has a very low activity level. The major radionuclide constituents are ${ }^{137} \mathrm{Cs}$ and ${ }^{90} \mathrm{Sr}$. Comparisons to established limits of concern for selected analytes can be made by referring to the Tank Characterization Reference Guide (De Lorenzo et al., 1994).

The results of the analyses have been compared to the dangerous waste codes in the Washington Dangerous Waste Regulations (WAC 173-303). This assessment was conducted by comparing tank analyses against dangerous waste characteristics (" $D$ " waste codes) and against state waste codes. It did not include checking tank analyses against " $U$ ", "P", "F", or "K" waste codes since application of these codes is dependent on the source of the waste and not on particular constituent concentrations. The results indicate that the waste in this tank is adequately described in the Dangerous Waste Permit Application for the Single-Shell Tank System; this permit is discussed in the Tank Characterization Reference Guide (De Lorenzo et al., 1994). 


\begin{tabular}{|c|c|c|c|c|}
\hline \multicolumn{5}{|c|}{$\begin{array}{c}\text { Single-Shell Tank 241-C-110 } \\
\text { Concentrations and inventories for Critical List Analytes } \\
\text { (as of April 1992) }\end{array}$} \\
\hline \multicolumn{5}{|c|}{ Physical Properties } \\
\hline Specific Gravity & Solid: 1.45 & \multicolumn{3}{|l|}{ Liquid: 1.09} \\
\hline $\mathrm{H}_{2} \mathrm{O}$ (Sludge) & $59.8 w t \%$ & \multicolumn{3}{|l|}{$616,000 \mathrm{~kg}$} \\
\hline pH & Solid: 11.0 & \multicolumn{3}{|l|}{ Liquid: 10.4} \\
\hline Heat Load & \multicolumn{4}{|l|}{$-136 \mathrm{~kW}$} \\
\hline $\begin{array}{l}\text { Chemical } \\
\text { Constituents }\end{array}$ & $\begin{array}{c}\text { Average } \\
\text { Solfid } \\
\text { Concentration }\end{array}$ & $\begin{array}{c}\text { Solid } \\
\text { Bulk } \\
\text { Inventory }\end{array}$ & $\begin{array}{l}\text { Average } \\
\text { Uquid } \\
\text { Concentration }\end{array}$ & $\begin{array}{c}\text { Liquid } \\
\text { Bulk } \\
\text { Inventory }\end{array}$ \\
\hline Al (Aluminum) & $1.4 w t \%$ & $14,900 \mathrm{~kg}$ & $0.00806 w t \%$ & $2.33 \mathrm{~kg}$ \\
\hline Bi (Bismuth) & 1.7 wt\% & $17,200 \mathrm{~kg}$ & $0.00581 w t \%$ & $1.68 \mathrm{~kg}$ \\
\hline Fe (Iron) & $1.1 \mathrm{wt} \%$ & $11,300 \mathrm{~kg}$ & $0.00433 w t \%$ & $1.25 \mathrm{~kg}$ \\
\hline Si (Silicon) & 0.71 wt\% & $7,350 \mathrm{~kg}$ & $0.00602 w \%$ & $1.74 \mathrm{~kg}$ \\
\hline Na (Sodium) & $8.2 w t \%$ & $84,800 \mathrm{~kg}$ & $4.12 w+\%$ & $1,190 \mathrm{~kg}$ \\
\hline F (Fluoride) & $0.76 w \%$ & $7.830 \mathrm{~kg}$ & 0.00474 wt\% & $13.7 \mathrm{~kg}$ \\
\hline $\mathrm{NO}_{3}^{-}$(Nitrate) & $11.1 \mathrm{wt} \%$ & $114,000 \mathrm{~kg}$ & $8.34 w t \%$ & $2,410 \mathrm{~kg}$ \\
\hline $\mathrm{NO}_{2}^{-}$(Nitrite) & $0.69 w+\%$ & $7.070 \mathrm{~kg}$ & $0.720 w t \%$ & $208 \mathrm{~kg}$ \\
\hline $\begin{array}{l}\mathrm{PO}_{4}{ }^{3-} \\
\text { (Phosphate) }\end{array}$ & $2.8 w t \%$ & $28.800 \mathrm{~kg}$ & $0.509 w t \%$ & $147 \mathrm{~kg}$ \\
\hline $\mathrm{SO}_{4}{ }^{2 \cdot}$ (Sulfate) & $1.5 w t \%$ & $15,200 \mathrm{~kg}$ & $1.02 \mathrm{wt} \%$ & $294 \mathrm{~kg}$ \\
\hline $\begin{array}{l}\text { Total Organic } \\
\text { Carbon }\end{array}$ & $0.080 w t \%$ & $823 \mathrm{~kg}$ & $0.0543 w t \%$ & $15.7 \mathrm{~kg}$ \\
\hline $\begin{array}{l}\text { Total Inorganic } \\
\text { Carbon }\end{array}$ & $0.14 w t \%$ & $1,440 \mathrm{~kg}$ & $0.186 w t \%$ & $<53.8 \mathrm{~kg}$ \\
\hline \multicolumn{5}{|l|}{ Radionuclides } \\
\hline${ }^{239 / 240} \mathrm{Pu}$ & $116 \mu \mathrm{Ci} / \mathrm{L}$ & $82.4 \mathrm{Ci}$ & $1.76 \mu \mathrm{Ci} / \mathrm{L}$ & $0.0466 \mathrm{Ci}$ \\
\hline Total Uranium & $0.15 \mu \mathrm{Ci} / \mathrm{L}$ & $1.520 \mathrm{~kg}$ & 0.0295 wt\% & $8.53 \mathrm{~kg}$ \\
\hline${ }^{13 i} \mathrm{Cs}$ & $28.200 \mu \mathrm{Ci} / \mathrm{L}$ & $20.000 \mathrm{Ci}$ & $7,300 \mu \mathrm{Ci} / \mathrm{L}$ & $211 \mathrm{Ci}$ \\
\hline${ }^{90} \mathrm{Sr}$ & $7.250 \mu \mathrm{Ci} / \mathrm{L}$ & $5,140 \mathrm{Ci}$ & $25.5 \mu \mathrm{Ci} / \mathrm{L}$ & $0.737 \mathrm{Ci}$ \\
\hline${ }^{99} \mathrm{TC}$ & $47.5 \mu \mathrm{Ci} / \mathrm{L}$ & $33.7 \mathrm{Ci}$ & $14.8 \mu \mathrm{Ci} / \mathrm{L}$ & $0.429 \mathrm{Ci}$ \\
\hline Total Alpha & $180 \mu \mathrm{Ci} / \mathrm{L}$ & $128 \mathrm{Ci}$ & $6.44 \mu \mathrm{Ci} / \mathrm{L}$ & $0.186 \mathrm{Ci}$ \\
\hline Total Beta & $61.300 \mu \mathrm{Ci} / \mathrm{L}$ & $43,500 \mathrm{Ci}$ & $3,350 \mu \mathrm{Ci} / \mathrm{L}$ & $99.6 \mathrm{Ci}$ \\
\hline
\end{tabular}

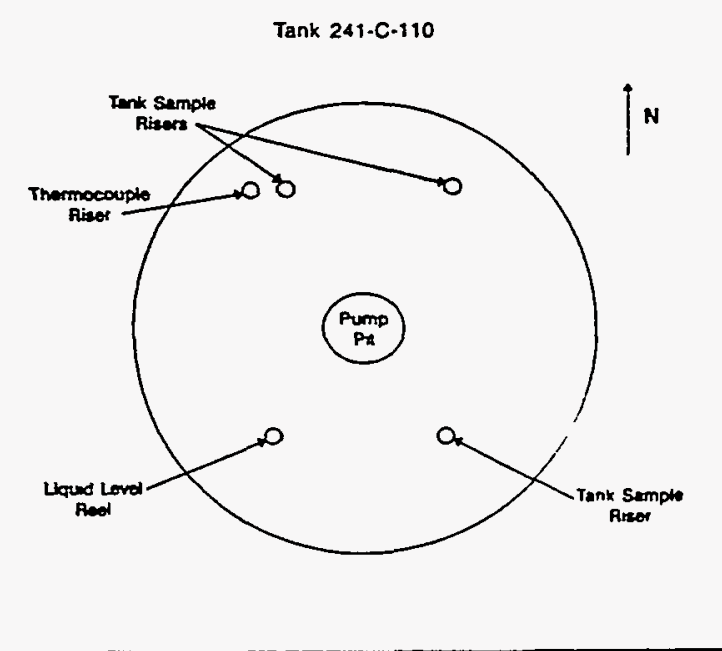

TANK 241-C-110

Tank Description

Type:

Single-Shell

Constructed:

In-Service:

1944 and 1945

Out of Service:

May 1946

1976

Diameter:

75 feet

Usable Depth:

16 Feet

Operating

Capacity:

530.000 gallons $(2,000,000 \mathrm{~L})$

Bottom Shape:

Dish

Hanford

Coordinates:

$42.932^{\circ}$ North $48.540^{\circ}$ West

Total Risers

Usable Risers

Ventilation:

Passive

Tank Status (as of June 1994)

Contents:

Dilute Complexed Waste

Total Waste:

187,000 gallons $(708,000 \mathrm{~L})$

Supernate Volume:

-0. gallons

Drainable Interstitial

7,000 gallons

$(26,500$ L)

Liquid:

Sludge:

187,000 gallons

(708,000 L)

Manual Tape Surface

Level:

Temperature:

65.5 inches $(294)$

Integrity Category:

Date Declared Leaker:

$66^{\circ} \mathrm{F}(05 / 1994)$

Assumed Leaker 1984

Leak Volume Estimate:

2,000 gallons (1989)

$17.570 \mathrm{~L}$

Isolation Status

Interim Stabilized:

0979

Partially Interim Isolated: 


\section{CONTENTS}

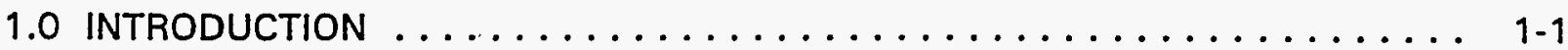

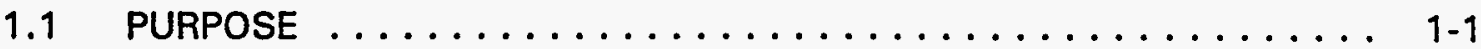

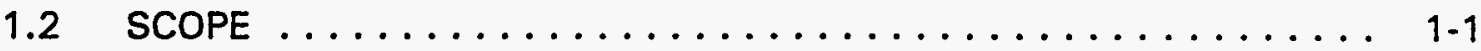

1.3 ASSUMPTIONS ........................ 1-2

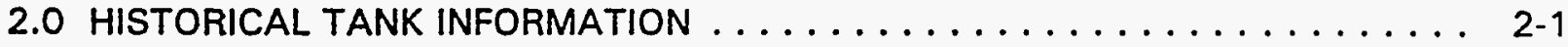

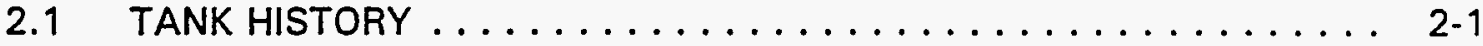

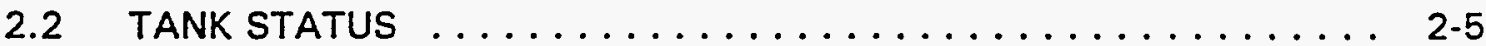

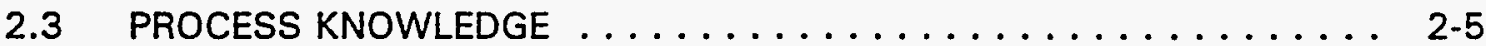

2.4 HISTORICAL ESTIMATION OF THE CONTENTS OF TANK 241-C-110 • 2-8

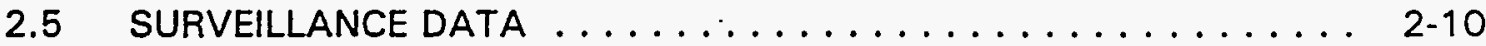

2.5.1 Surface Level Readings . . . . . . . . . . . . . . 2-10

2.5.2 Internal Tank Temperatures ................. 2-10

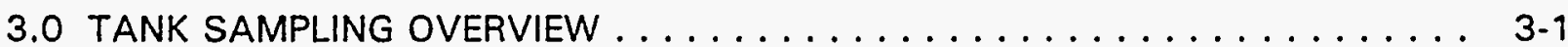

3.1 DESCRIPTION OF SAMPLING EVENT $\ldots \ldots \ldots \ldots \ldots \ldots \ldots$

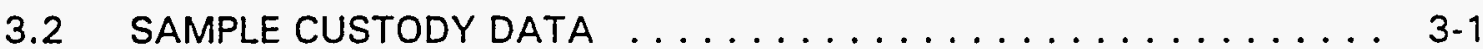

3.3 PROBLEMS WITH THE SAMPLES $\ldots \ldots \ldots \ldots \ldots \ldots \ldots \ldots$

4.0 SAMPLE HANDLING AND ANALYSIS SCHEME $\ldots \ldots \ldots \ldots \ldots \ldots \ldots$

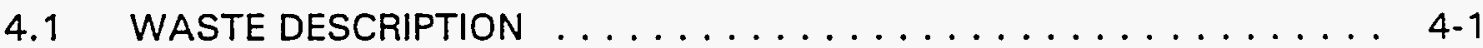

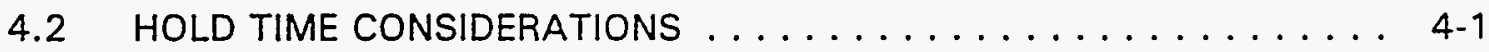

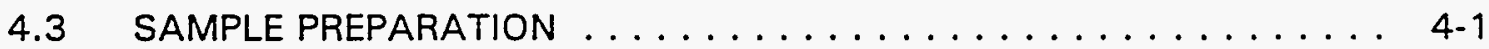

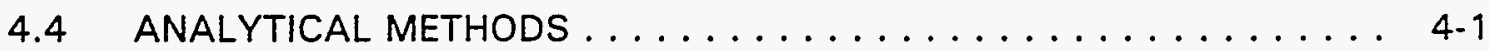

4.4.1 Physical and Rheological Tests . . . . . . . . . . . . . . . 4-2

4.4.2 Chemical and Radionuclide Constituent Analysis ........ . 4-2

4.4 .3 Organic Constituent Analyses ............... 4-2

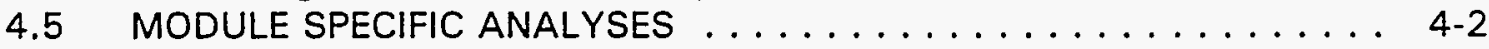

5.0 ANALYTICAL RESULTS AND WASTE INVENTORY $\ldots \ldots \ldots \ldots \ldots \ldots \ldots$

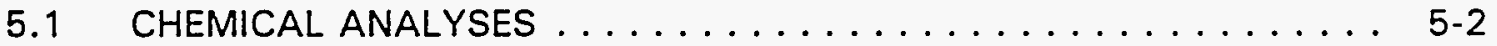

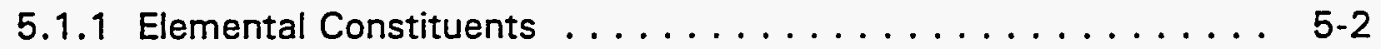

5.1 .2 Anions ...................... 5-3

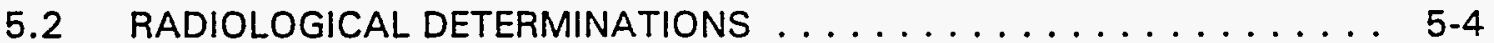

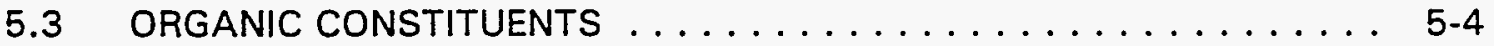

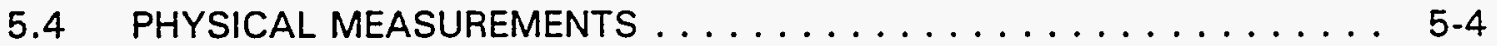

5.4 .1 Specific Gravity . . . . . . . . . . . . . . . . . . 5 5-4

5.4 .2 Percent Water . . . . . . . . . . . . . . . . . 5-5

5.4 .3 Rheology ...................... 5-5

5.4 .4 Energetics ..................... $5-5$

5.5 DATA PRESENTATION ................... 5-6

6.0 ANALYTICAL RESULTS INTERPRETATION $\ldots \ldots \ldots \ldots \ldots \ldots \ldots \ldots \ldots$

6.1 TANK WASTE PROFILE . . . . . . . . . . . . . . . 6 . 1

LATA-TCR-9407, Rev. 0 iii 
CONTENTS (continued)

6.2 WASTE SUMMARY AND CONDITIONS $\ldots \ldots \ldots \ldots \ldots \ldots \ldots \ldots$

6.2 .1 Spatial Variability Description . . . . . . . . . . . . . . . . . 6-2

6.2.2 Comparisons Between Historical Data and Recent Analytical

Data ........................... 6-2

6.2 .3 Leak Inventory Estimate . . . . . . . . . . . . . 6 6-3

6.2 .4 Projected Tank Heat Load .................... 6 6-5

6.3 PROGRAM ELEMENT SPECIFIC ANALYSES . . . . . . . . . . . $6-5$

7.0 STATISTICAL INTERPRETATION $\ldots \ldots \ldots \ldots \ldots \ldots \ldots \ldots \ldots \ldots \ldots$

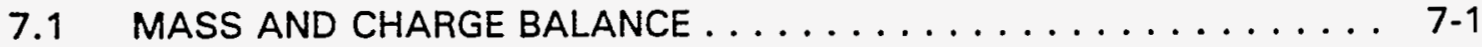

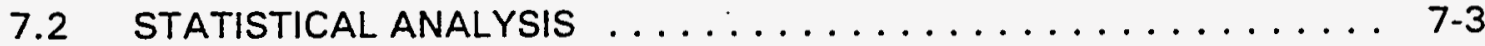

7.2 .1 Introduction ....................... 7-3

7.2 .2 Sample Homogenization Test . . . . . . . . . . . . . 7-4

7.2.3 Comparison of Variance Component Estimates . . . . . . . . 7-4

7.3 ANALYTICAL ERROR ESTIMATION $\ldots \ldots \ldots \ldots \ldots \ldots \ldots \ldots$

7.3.1 Random Analytical Error . . . . . . . . . . . . . 7-7

7.3 .2 Systematic Analytical Error . . . . . . . . . . . 7-8

8.0 CONCLUSION AND RECOMMENDATIONS $\ldots \ldots \ldots \ldots \ldots \ldots \ldots \ldots \ldots$

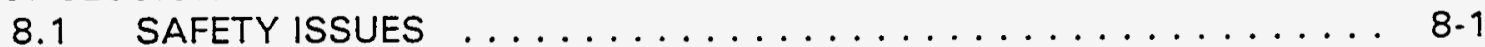

8.2 FURTHER CHARACTERIZATION NEEDS $\ldots \ldots \ldots \ldots \ldots \ldots \ldots \ldots$

8.3 CONCLUSIONS $\ldots \ldots \ldots \ldots \ldots \ldots \ldots \ldots \ldots \ldots \ldots \ldots \ldots \ldots$

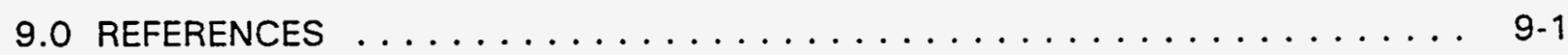

APPENDIX A ANALYTICAL DATA ................... A-i

APPENDIX B HISTORICAL INVENTORY ESTIMATES COMPARISON . . . . . . . . B-i

APPENDIX $C$ THE ANOVA MODEL $\ldots \ldots \ldots \ldots \ldots \ldots \ldots \ldots \ldots \ldots$

\section{LIST OF FIGURES}

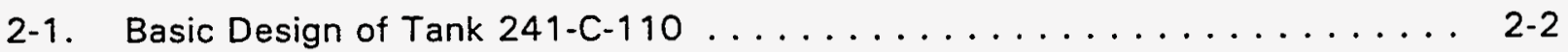

2-2. Riser Configuration for Tank $241-\mathrm{C}-110 \ldots \ldots \ldots \ldots \ldots$

2-3. Location of the 241-C Tank Farm . . . . . . . . . . . . . . . 2-4

2-4. Waste Volume History of Tank $241-C-110 \ldots \ldots \ldots \ldots$

2-5. Tank 241-C-110 Surface Level Readings . . . . . . . . . . . 2-11

2-6. Tank 241-C-110 Temperatures Since $1988 \ldots \ldots \ldots \ldots \ldots$ 2-12 
WHC-SD-WM-ER-367 REV 0

\section{LIST OF TABLES}

2-1. Estimated Total Volume of Each Waste Type Received by Single-Shell Tank

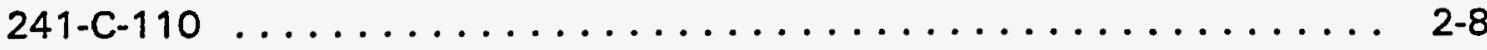

2-2. Historical Tank Inventory Estimate of Tank 241-C-110 . . . . . . . . . 2-9

3-1. WHC 222-S Laboratory Sample Custody Data . . . . . . . . . . . . . . . 3-2

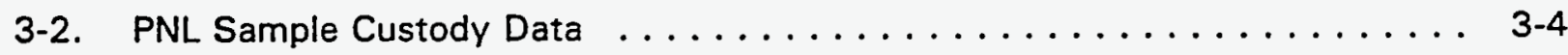

3-3. Samples and Requested Analytes for the 222-S Laboratory . . . . . . . . . 3-5

3-4. Samples and Requested Analyses For PNL .............. 3-5

3-5. Tank 241-C-110 Core Sample \% Recovery and Liquid/Solid Fraction . . . . . 3-6

4-1. Analytical Methods for Physical and Rheological Testing . . . . . . . . . . . 4-2

4-2. Analytical Methods for Chemical and Radionuclide Analyses . . . . . . . . . 4-3

4-3. Analytical Methods For Organic Analyses . . . . . . . . . . . . . . . 4-3

5-1. Analytical Data Presentation Tables ................... 5-1

5-2. Comparison of Drainable Liquid and TCLP Data . . . . . . . . . . . . . 5-2

5-3. Comparison of ICP and IC Phosphate and Sulfate Results . . . . . . . . . 5-3

5-4. Physical Properties Obtained from Core $37 \ldots \ldots \ldots \ldots \ldots$

5-5. Tank Characterization Report Data for Total Solid Material in Single-Shell

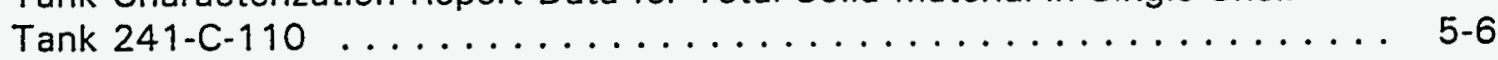

5-6. Tank Characterization Report Data for Liquid in Single-Shell Tank 241-C-110 . 5-9

6-1. Neutralized First Cycle Waste Composition ................ 6-1

6-2. Inventory Assumed Leaked From Tank $241-\mathrm{C}-110 \ldots \ldots \ldots \ldots$

6-3. Tank 241-C-110 Heat Load . . . . . . . . . . . . . . . . 6-5

6-4. Applicability of Characterization Information to the Data Needs of the TWRS Program Elements ........................ 6-6

LATA-TCR-9407, Rev. 0 v 


\section{LIST OF TABLES (continued)}

7-1. Tank 241-C-110 Mass and Charge Balance ................ 7-1

7-2. Special Analyte List. . . . . . . . . . . . . . . . . . . 7-3

7-3. Variance Components Test Results ................... 7-4

7-4. Measurement Error Estimates $\ldots \ldots \ldots \ldots \ldots \ldots \ldots \ldots$ 


\section{LIST OF TERMS}

$\begin{array}{ll}\text { ANOVA } & \text { analysis of variance } \\ \text { CASS } & \text { Computer Automated Surveillance System } \\ \text { CW } & \text { coating waste } \\ \text { DL } & \text { detection limit } \\ \text { DNFSB } & \text { Defense Nuclear Facilities Safety Board } \\ \text { DOE } & \text { United States Department of Energy } \\ \text { DSC } & \text { differential scanning calorimetry } \\ \text { EB } & \text { evaporator bottoms } \\ \text { EOX } & \text { extractable organic halides } \\ \text { EPA } & \text { U. S. Environmental Protection Agency } \\ \text { HTCE } & \text { Historical Tank Content Estimates } \\ \text { IC } & \text { ion chromatography } \\ \text { ICP } & \text { inductively coupled plasma } \\ \text { IX } & \text { ion exchange } \\ \text { MDL } & \text { method detection limit } \\ \text { ND } & \text { not detected } \\ \text { NPH } & \text { normal paraffin hydrocarbons } \\ \text { OWW } & \text { organic solvent wash waste } \\ \text { PNL } & \text { Pacific Northwest Laboratory } \\ \text { PUREX } & \text { Plutonium-Uranium Extraction Plant } \\ \text { RPD } & \text { relative percent difference } \\ \text { RSD } & \text { relative standard deviation } \\ \text { SACS } & \text { Surveillance Analysis Computer System } \\ \text { SVOA } & \text { semivolatile organics analysis } \\ \text { TBP } & \text { tributyl phosphate } \\ \text { TCLP } & \text { toxicity characteristic leach procedure } \\ \text { TGA } & \text { thermogravimetric analysis } \\ \text { TMACS } & \text { Temperature Monitoring and Control System } \\ \text { TOX } & \text { total organic halides } \\ \text { TRAC } & \text { Track Radioactive Components } \\ \text { TWRS } & \text { Tank Waste Remediation System } \\ \text { VOA } & \text { volatile organics analysis } \\ \text { WHC } & \text { Westinghouse Hanford Company } \\ \text { TC } & \text { first-cycle decontamination waste } \\ & \end{array}$




\subsection{INTRODUCTION}

In April of 1992, Single-Shell Tank 241-C-110 was sampled in order to comply with requirements of the Hanford Federal Facility Agreement and Consent Order (Ecology, EPA \& DOE, 1993) and the Washington Administrative Code (Ecology, 1991). The analyses also provided information to the Tank Waste Remediation System in terms of tank safety, waste retrieval, and waste disposal. This Tank Characterization Report presents an overview of that tank sampling and analysis effort, and contains observations regarding waste characteristics. It also addresses expected concentration and inventory data for the waste contents based on this latest sampling data and background tank information.

\subsection{PURPOSE}

The purpose of this report is to describe and characterize the waste in Single-Shell Tank 241-C-110 (hereafter known as Tank 241-C-110) based on information gathered from various sources. This report summarizes the available information regarding the waste in Tank 241-C-110, and arranges it in a useful format for making management and technical decisions concerning this particular waste tank.

Specific objectives reached by the sampling and characterization of the waste in Tank 241-C-110 are:

- Contribute toward the fulfillment of the Hanford Federal Facility Agreement and Consent Order (Tri-Party Agreement) Milestone M-44-05 concerning the characterization of Hanford Site high-level radioactive waste tanks (Ecology, EPA \& DOE, 1993).

- Complete safety screening of the contents of Tank 241-C-110 to meet the characterization requirements of the Defense Nuclear Facilities Safety Board (DNFSB) Recommendation 93-5 (Conway, 1993).

- Provide tank waste characterization to the Tank Waste Remediation System (TWRS) Program Elements in accordance with the TWRS Tank Waste Analysis Plan (Bell, 1994).

\subsection{SCOPE}

This report begins with a broad description and historical background of the tank. This allows a detailed estimation of the contents of Tank 241-C-110 based on historical process information and detailed transaction records. Next, the results of the sampling and analysis effort are summarized and interpreted both qualitatively and statistically. The information obtained from historical sources is then compared with the actual waste measurements to arrive at final waste inventory and concentration estimates. Finally, recommendations are given based on the current waste inventory and tank status. 


\subsection{ASSUMPTIONS}

The concentration and inventory estimates derived for this report are considered by the authors and by the Westinghouse Hanford Company Characterization Program to be the most accurate, defensible, technically valid, and contemporary data concerning Tank 241-C-110. This Tank Characterization Report incorporates all available previous sampling, characterization, and transfer data concerning Tank 241-C-110. In addition, estimates of the current tank contents based on process knowledge, surveillance data, and waste transaction records provide important cross-checks and corroboration to the inventory estimates derived from recent analytical data. Given that the analytical data is valid and defensible, this report is therefore the definitive characterization of the contents of Tank 241-C-110, at this time. Since Tank 241-C-110 was removed from service in 1976 (Anderson, 1990) and partially interim isolated in 1982 (Husa et al., 1993), the contents of the tank will likely remain unchanged.

The term "analytical results" is used in this report to denote sample results from the most recent sampling event. Characterization data from these samples are used as the basis for the analytical section of this report, Section 5.0. The historical assessment of these tank contents presented in Section 2.0 is based on process knowledge and the available "historical results" prior to the 1992 sampling. The characterization of Tank 241-C-110 is considered accurate and representative of the tank contents as of the date of preparation of this report: August, 1994. 


\subsection{HISTORICAL TANK INFORMATION}

The purpose of this section is to describe Tank $241-\mathrm{C}-110$ based on historical information. It is divided into five parts. A brief description and historical background of the tank comprise the first part, followed by the current tank status, a summary of the process sources that contributed to the tank waste, and an estimation of the contents of Tank 241-C110 based on historical information. The final part details the surveillance data taken on the tank.

\subsection{TANK HISTORY}

Single-Shell Tank 241-C-110 consists of a carbon steel tank within a reinforced concrete shell and dome. It has a diameter of $75 \mathrm{ft}$., an operating depth of $16 \mathrm{ft}$., and a capacity of 530,000 gallons (Husa et al., 1993). The basic design of Tank 241-C-110 is shown in Figure 2-1. Instruments access Tank 241-C-110 through risers and monitor the temperature, sludge level, and other bulk tank characteristics (Fulton, 1994). The position of these risers is found in Figure 2-2.

The 241-C Tank Farm, built in 1943 and 1944, is one of the initial four tank farms to be used at the Hanford Site. It is located on the eastern side of the 200 East Area. Figure 2-3 details the Hanford Site's 200 East Area and the location of the 241-C Tank Farm. As shown in Figure 2-2, Tank 241-C-110 is found in the far left corner of the 241-C Tank Farm.

Tank 241-C-110 is the first tank in a "cascade" connecting it to Tanks C-111 and C112. A cascade was a system in which a number of tanks were connected in series by pipes. These pipes were located at the top of the tanks' working depths. Once the first tank in a cascade was full, additional waste would spill over into the next tank, thereby preventing over filling of the first tank. Also, by using a cascade, fewer connections needed to be made during waste handling operations. This method reduced waste handling requirements, personnel exposure, and the chance of a loss of tank integrity from waste overflow. Another advantage of using the cascades was to clarify the waste. Entrained solids would settle and insoluble constituents would precipitate in the first tank (in this case Tank 241-C-110), and the clarified liquids would flow through the cascade on to the other tanks $(241-\mathrm{C}-111$ and 241-C-112). This practice led to rapid filling of the first tank with solids, and allowed the clarified liquid from the other tanks in the cascade to be discharged to cribs. The cascade connections in the 241-C Tank Farm are illustrated in Figure 2-2.

Tank 241-C-110 went into service in 1946, receiving first cycle decontamination (1C) waste (Anderson, 1990). The cascade outlet to Tank 241-C-111 was blocked in 1952. The history of Tank 241-C-110 can be summarized as a series of waste transfers into the tank, settling and precipitation of the tank contents, and then partial pumping of the supernate. 
5
8
0
1
-1
0
00
0
0
0
0
-1
00
0
$<$
0

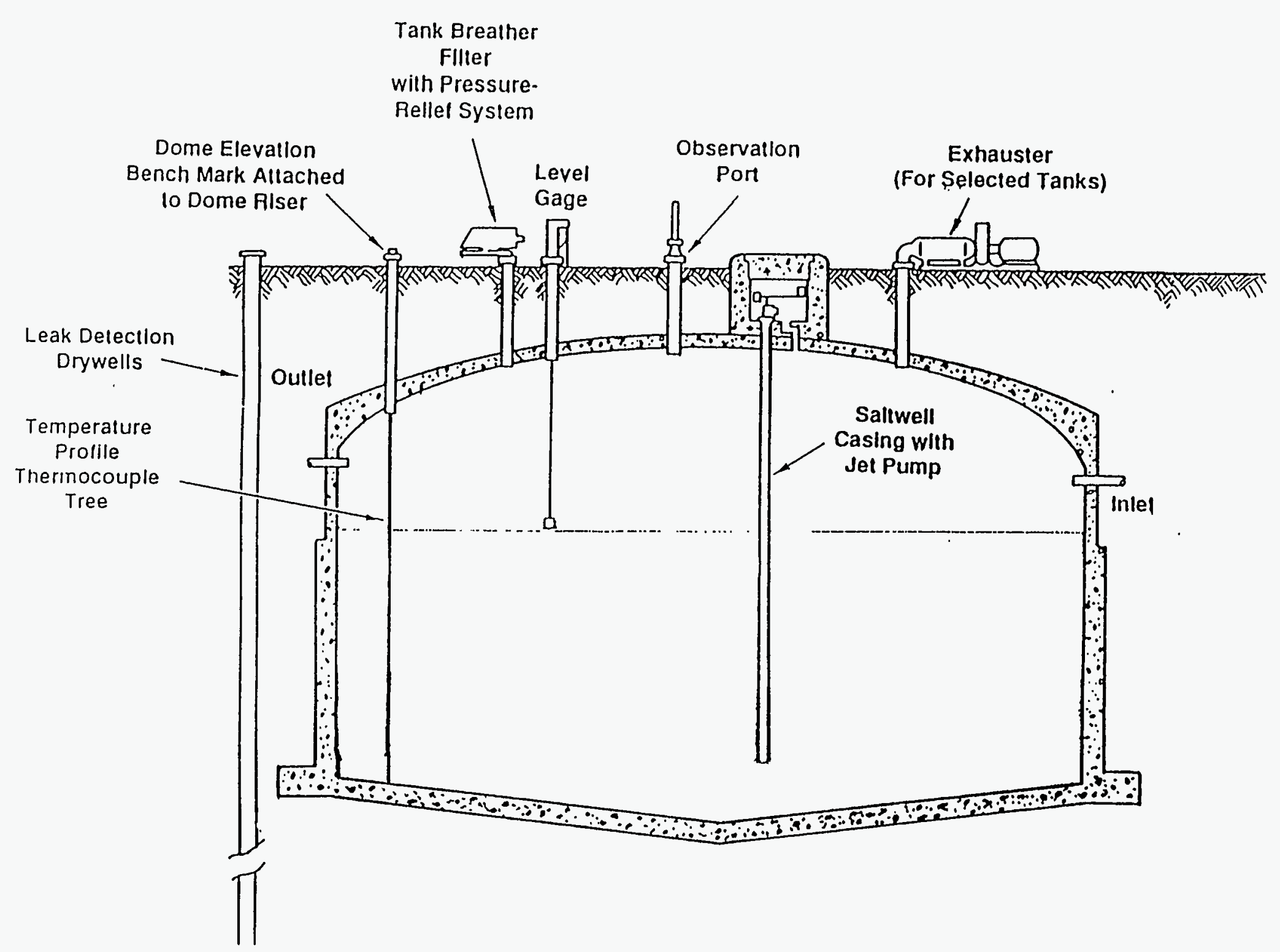




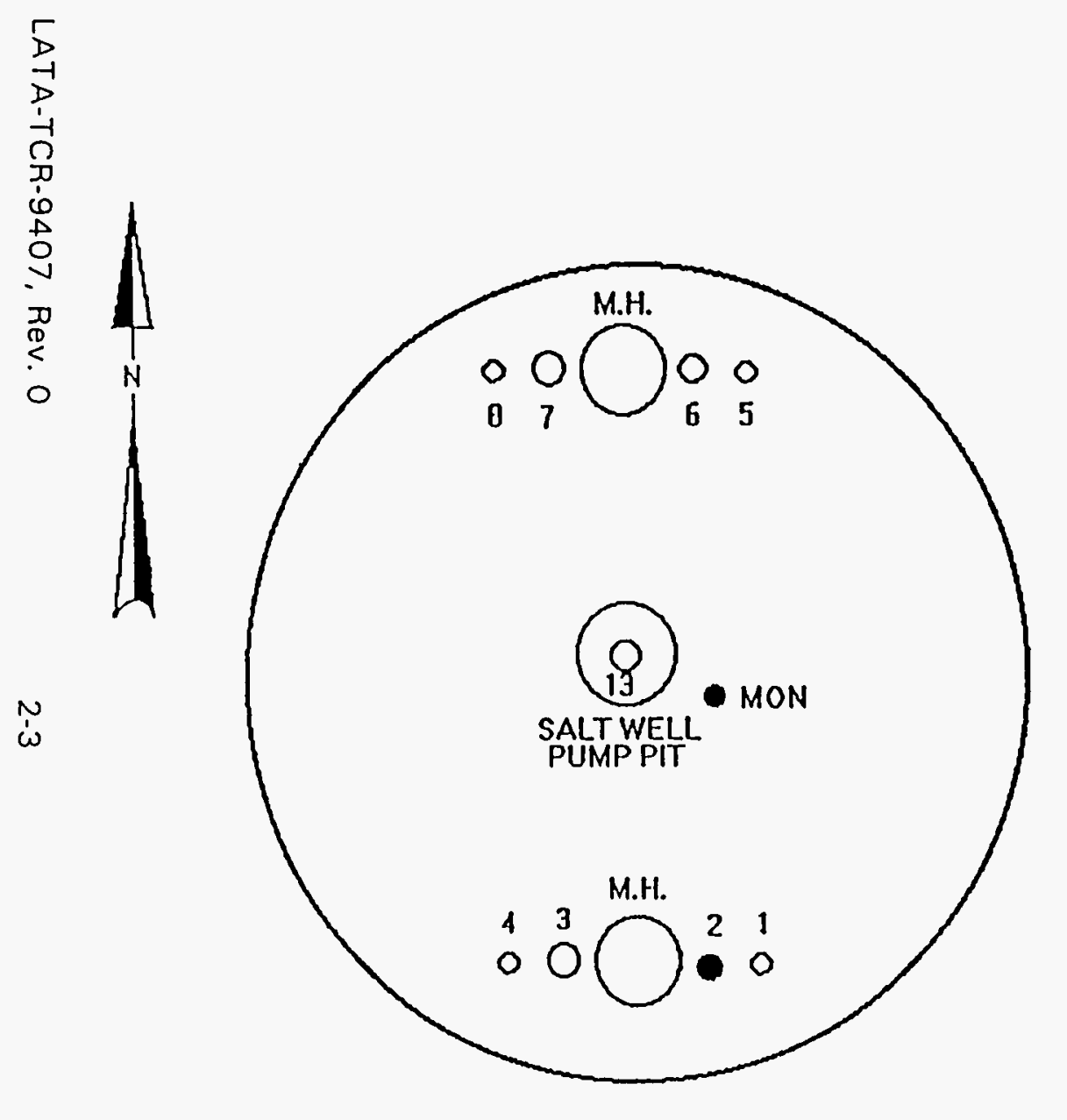

M.H. Manhole In iser dome. no rlser to surface

\begin{tabular}{|c|c|c|c|}
\hline \multicolumn{4}{|r|}{$249-c-110$} \\
\hline Ho. & DiA. & ELEV. & DESCRIPIIOH AND COMMENTS \\
\hline 1 & 6n & 048.17 & SHP \\
\hline 2 & $12^{m}$ & 648.17 & FLANGE, BH \\
\hline 3 & $12^{11}$ & 640.19 & BREATHER FILTER \\
\hline 4 & 4n & 648.21 & LIOUIO LEVEL REEL \\
\hline 5 & 4n & 067.72 & FLANGE \\
\hline 6 & 12" & 647.73 & FLAHGE UITH BALE \\
\hline 7 & $12^{\prime \prime}$ & 647.72 & FLANGE UITH LEAO/B-222 OBSV PORT \\
\hline 8 & L" & 647.70 & IEMPERATURE PROBE \\
\hline 13 & 12" & 644.08 & SALTHELL SCREEN \\
\hline & & & \\
\hline & & & \\
\hline & & & \\
\hline & & & \\
\hline & & & \\
\hline & & & \\
\hline & & & \\
\hline
\end{tabular}

$c_{L}$ IHSIDE TAHK BOTTOH -610.00

REF DUGS DOHE PLAH/AS BLT H-2-37010 RISER ELEV H-2-1744, H-2-37912, H-2-72743 ISOLATION $H-2 \cdot 73350$
$6 / 30 / 88$ 
Figure 2-3. Location of the 241-C Tank Farm.

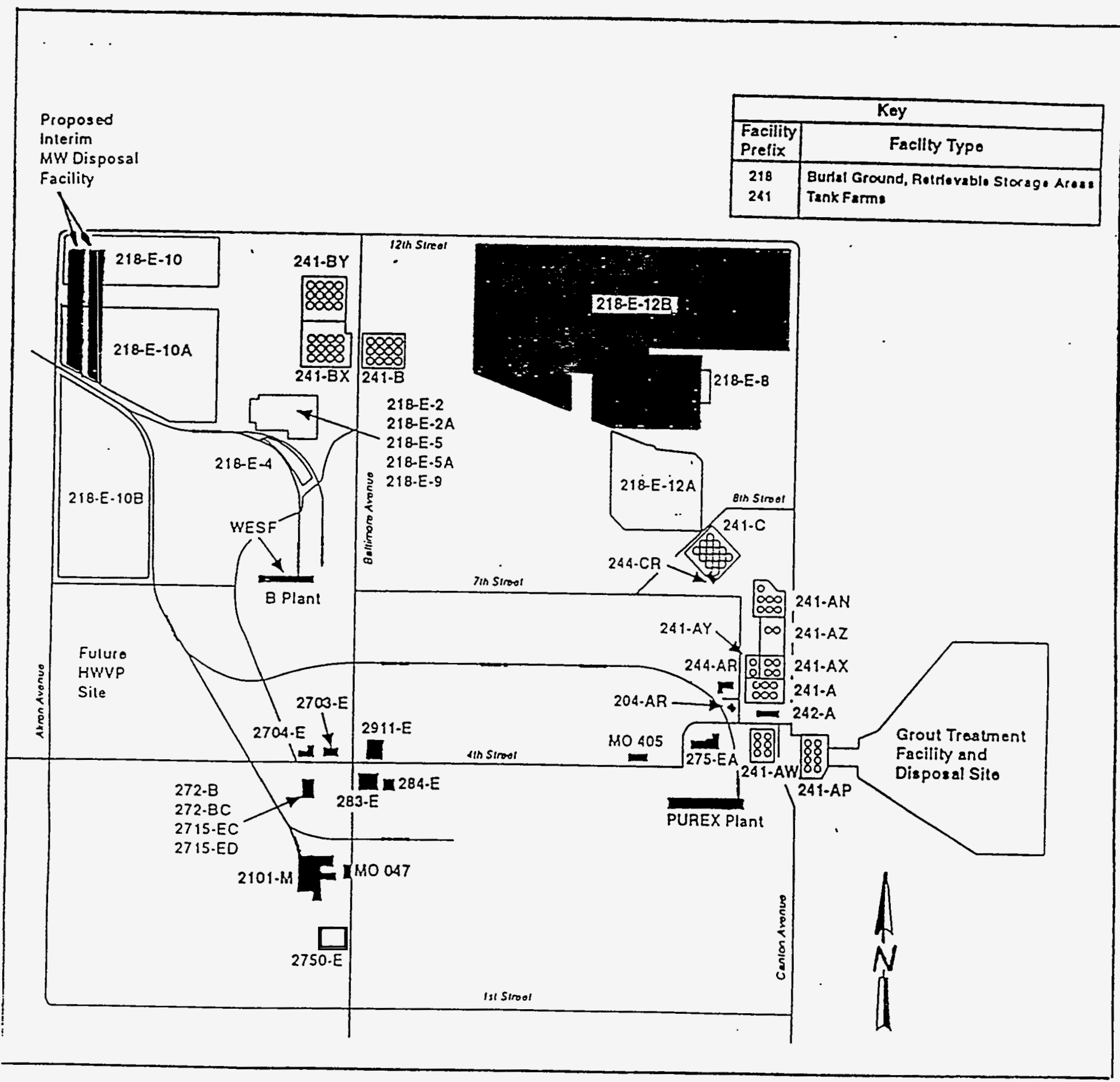


Four dry wells were drilled around Tank 241-C-110 in 1974 and 1975 . Supernate was removed in 1975, and in 1976 the tank was salt well pumped to remove the remaining pumpable liquid. Tank 241-C-110 was officially removed from service in 1976. In 1977, Tank 241-C-110 was categorized as Questionable Integrity. It received this listing because of elevated radiation levels in dry well \#30-10-09. Tanks with this label were suspected of leaking, although surveillance data did not provide conclusive evidence of leakage (Baumhardt, 1989). In fact, according to Welty (1988), intrusions occurred from 1977 to 1986 , as the waste level actually increased without any waste being added. Primary stabilization of the tank took place in 1979.

In 1984, the Questionable Integrity designation was combined with the Confirmed Leaker category to create the current Assumed Leaker classification. Thus, Tank 241-C-110 was declared an Assumed Leaker in 1984. Since no detectable liquid level decrease had occurred, a leak estimate could not be derived from surveillance data. Instead, 2,000 gallons was chosen as the leak estimate, for it was decided that surface levels would have reflected the leak if it had been more that 2,000 gallons (Baumhardt, 1989). This leak estimate was updated in 1989. Finally, from December 1991 to January 1992, Tank 241-C-110 was again salt well pumped, removing any remaining pumpable liquid.

\subsection{TANK STATUS}

Tank 241-C-110 currently contains 187,000 gallons of sludge, with an estimated 7,000 gallons of the waste existing as drainable interstitial liquid (Hanlon, 1994). Current monitoring information indicates that the waste level extends approximately 65 inches from the baseline of the tank. (A baseline level measurement is taken near the side of the tank, and does not take the 12 " dished bottom into consideration). Thermocouple data indicates that the waste temperature is $66^{\circ} \mathrm{F}$ and supports the conclusion that there are no significant heatgeneration processes within the tank wastes. Liquid levels and tank temperatures are further discussed in Section 2.5. Ventilation for Tank 241-C-110 is passive (i.e., there are no forcedair exhausters). All monitoring systems are currently in compliance with established standards (Hanlon, 1994).

The current designation of the tank contents is dilute complexed waste. Tank 241-C110 is not a Watch List tank, nor does it have Unreviewed Safety Questions associated with it. Tank 241-C-110 has been labeled an Assumed Leaker, and has been partially interim isolated. Partial interim isolation is the administrative designation reflecting the completion of physical modifications to tank piping systems to preclude the inadvertent addition of waste, with the exception of isolation of risers and piping necessary for jet pumping or other methods of stabilization.

\subsection{PROCESS KNOWLEDGE}

As mentioned in Section 2.1, the operating history of Tank 241-C-110 can be simplified to consist of 3 processes: a series of waste transfers into the tank (from separation plants or other tanks), settling and precipitation of the tank contents, and then partial pumping of the supernate. Figure $2-4$ summarizes Tank $241-\mathrm{C}-110$ historic waste volume measurements. 
WHC-SD-WM-ER-367 REV O

Figure 2-4. Waste Volume History of Tank 241-C-110.

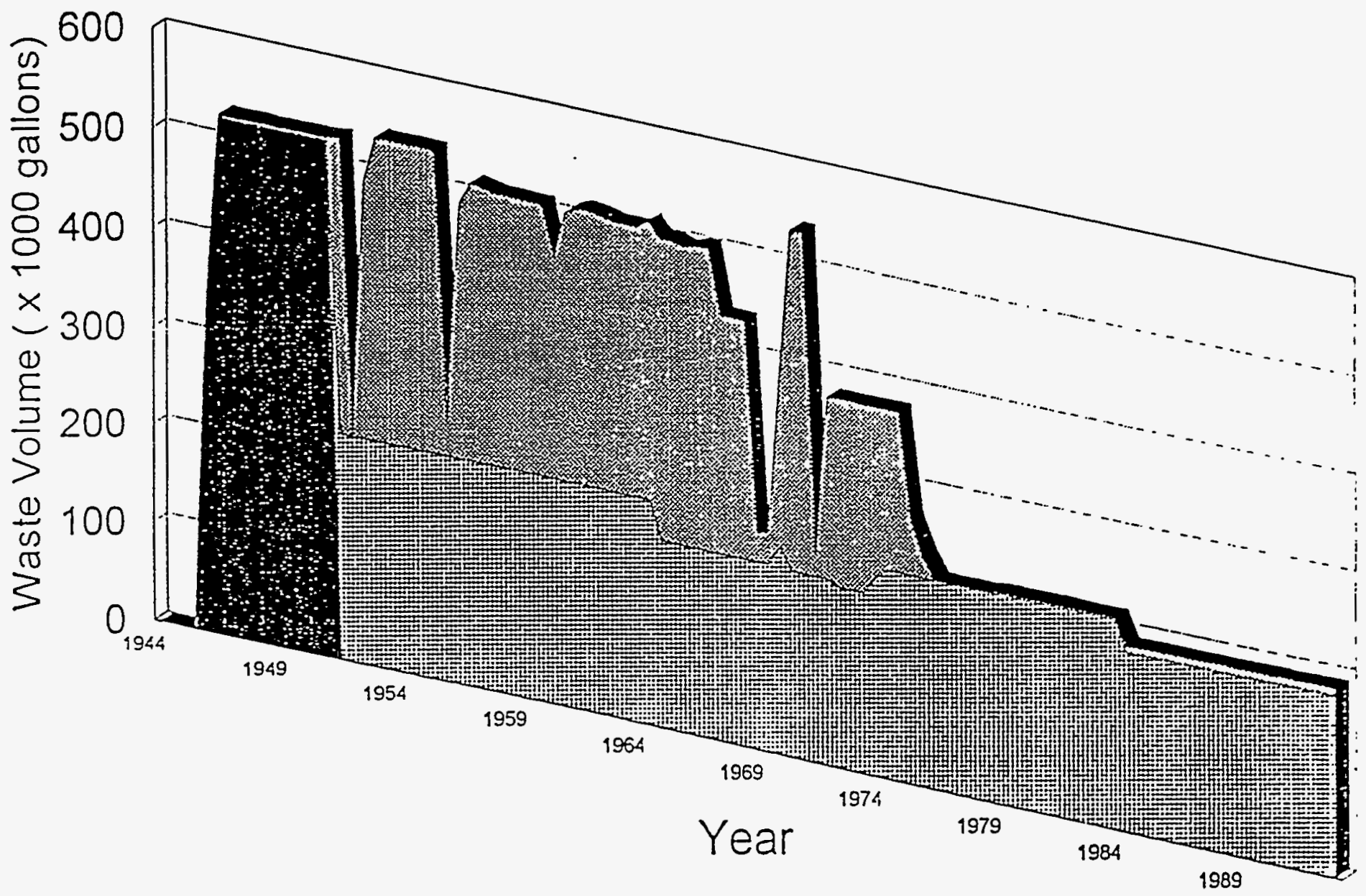


The first waste type to be introduced into Tank 241-C-110 was first cycle decontamination (1C) waste in 1946. Produced in the $\mathrm{BiPO}_{4}$ process at the $\mathrm{B}$ and $\mathrm{T}$ plants, $1 \mathrm{C}$ waste consisted of byproducts co-precipitated from a plutonium-containing solution. Coating waste from the removal of aluminum fuel element cladding was added to the tank, and comprised about $24 \%$ of the total waste stream. The 1C waste completely filled the tank, and then cascaded on to Tanks $\mathrm{C}-111$ and $\mathrm{C}-112$. This waste then settled for a number of years, and the supernate was pumped off to make room for further waste additions (Anderson, 1990).

Tank 241-C-110 began receiving waste from the TBP uranium-extraction process at $U$ Plant in 1952 and was filled by early 1953. The TBP waste was composed of concentrated, neutralized aqueous effluent from the primary extraction column and from the solvent wash. Several years elapsed, during which time settling of the TBP wastes occurred. It is possible that during this time settled $1 \mathrm{C}$ solids were partially re-dissolved by the TBP liquids, since the TBP was used as an extractant for 1C discharges. Tank 241-C-110 supernate was again drawn off, this time to the 001-CR crib. Since the waste was discharged to a crib, it likely contained primarily clarified liquids.

The next addition to the tank in the second quarter of 1956 was organic solvent wash waste (OWW), containing carbonate, permanganate, and nitrate, from the Plutonium-Uranium Extraction (PUREX) Plant. The waste was then allowed to settle for a full 10 years before further tank operations were conducted. During this time, the solids volume as measured by in-tank electrodes (instruments utilizing metal plates which sink until they contact the sludge layer) decreased markedly (Anderson, 1990). The likely causes for this were further settling of the sludges, and the re-dissolution of previously solidified wastes. Following the transfer of the majority of the supernate from Tank 241-C-110 in 1969, the tank received ion exchange (IX) waste supernate from Tank 241-BY-104 in 1970. Subsequent to this, large volumes of evaporator bottoms (EB) and IX waste were transferred into Tank 241-C-110, from Tank 241-BX-104, and then out again to other tanks. This left the tank completely full, primarily with the previously settled solids and the newly transferred liquids. Generated from the cesium recovery process at the B Plant, IX waste included column waste, column wash waste, and cesium purification waste. Evaporator bottoms were a slurry product from the evaporators, and would precipitate as a solid salt cake which was then stored in the singleshell tanks.

Following pumping of most of the supernatant, Tank $241-C-110$ received its last waste when supernate from coating waste (CW) and OWW were transferred from Tank 241-BX-103 in 1972. Coating waste was produced at the PUREX Plant from the dissolution of zircaloy fuel cladding (after 1964) in an ammonium fluoride-ammonium nitrate solution. The tank was allowed to settle for several years, and then further pumping of the supernate began; salt well pumping further reduced the waste volume to approximately 211,000 gallons in the late 1970s: The waste volume has since decreased to the present waste volume of 187,000 gallons. Since the tank is an Assumed Leaker, it is possible that tank leakage accounts for some of the volume change and gravitational settling accounts for the rest. A salt well pumping campaign in 1991 accounts for almost 10,000 gallons of volume change. 


\subsection{HISTORICAL ESTIMATION OF THE CONTENTS OF TANK 241-C-110}

By examining the approximate chemical composition of each waste stream introduced to Tank 241-C-110, and the inflows, outflows and transfers between tanks, estimated concentrations for selected elements, compounds, and isotopes can be developed. It is important to consider, however, that historical records are incomplete and were kept intermittently.

The following waste types have been transferred to Tank 241-C-110 throughout its operational lifetime: 1C, TBP, OWW, IX, EB, and CW (Anderson, 1990). It should be noted that Tank 241-C-110 was the first member of a cascade, which meant that it probably received more solid waste than the other two tanks when the cascade was operable. It is also important to note the quantity and chronology of the waste received. These guiding parameters indicate that Tank 241-C-110 received a large amount of solid $1 \mathrm{C}$ waste before any other waste type was introduced in the tank. For this reason, it is very likely that $1 \mathrm{C}$ waste will be the predominant waste type in Tank 241-C-110, and that it will chiefly occupy the lower portions of the tank. Estimates of the total amount of each waste type received by Tank 241-C-110, including waste volumes that have cascaded through the tank, are summarized in Table 2-1.

Table 2-1. Estimated Total Volume of Each Waste

Type Received by Single-Shell Tank 241-C-110

(Anderson, 1990).

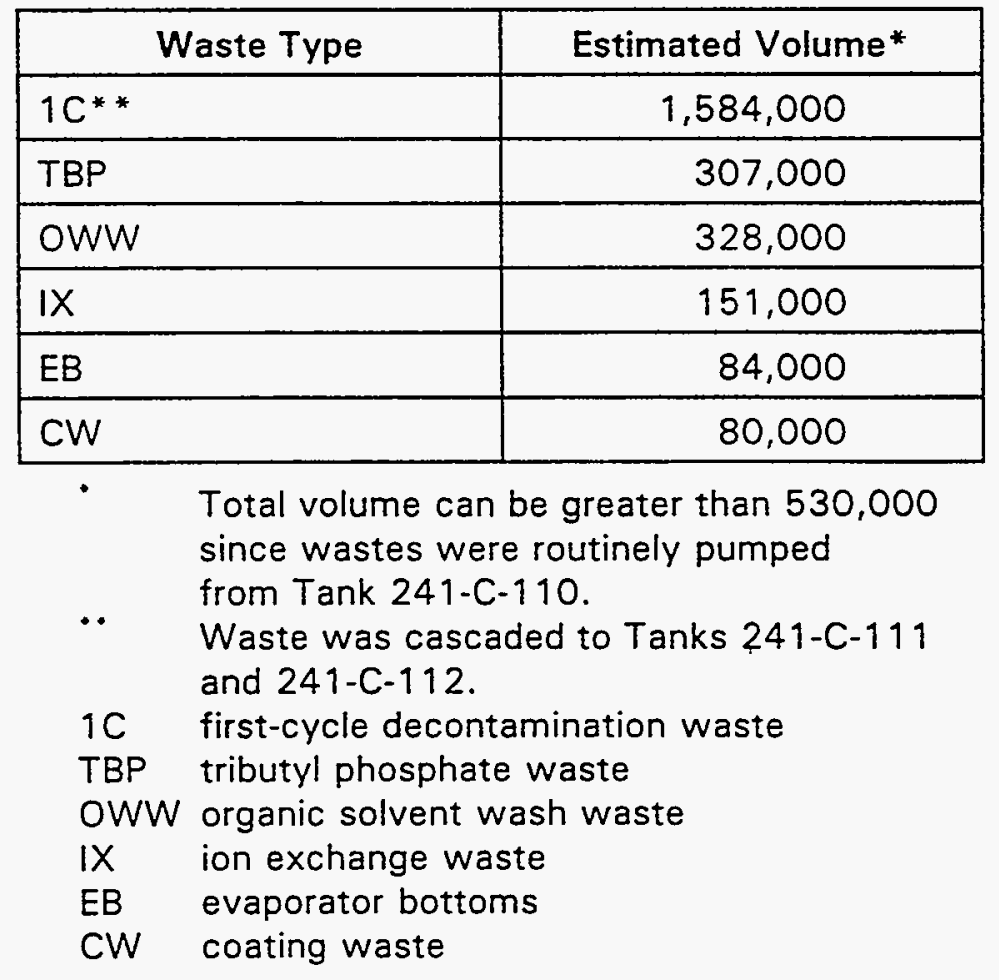

A preliminary estimate of the waste constituents in Tank 241-C-110 can be generated by reviewing the historical characterization data for the tank. This estimate is compared with the most recent analytical data in Section 5.0. The Tank 241-C-110 historical tank inventory 
estimates reported in this Tank Characterization Report were produced using a model developed by Los Alamos National Laboratories, and reported and explained in the Historical Tank Content Estimates (HTCE) (ICF Kaiser Hanford, 1994). These inventory numbers were generated based on the assumption that the waste is $100 \% 1 \mathrm{C}$ sludge. Table $2-2$ contains the estimated inventories from the HTCE. These values also appear in Table $5-5$ as the Historic Tank Content Estimate for the solid material in Tank 241-C-110.

Table 2-2. Historical Tank Inventory Estimate of

Tank 241-C-110 (ICF Kaiser Hanford, 1994).

\begin{tabular}{|c|c|c|}
\hline \multicolumn{3}{|c|}{ Physical Properties } \\
\hline Bulk Density & \multicolumn{2}{|c|}{1.34} \\
\hline Void Fraction & \multicolumn{2}{|c|}{0.58} \\
\hline Water wt\% & \multicolumn{2}{|c|}{68.4} \\
\hline \multicolumn{3}{|c|}{ Chemical Constituents } \\
\hline Analyte & $\mu g / g$ & $\mathrm{Kg}$ \\
\hline $\mathrm{Na}$ & $1.00 E+05$ & $9.47 E+04$ \\
\hline Al & $6.06 E+03$ & $5.73 E+03$ \\
\hline $\mathrm{Fe}$ & $9.15 E+03$ & $8.66 E+03$ \\
\hline $\mathrm{Cr}$ & $5.68 E+02$ & $5.37 E+02$ \\
\hline $\mathrm{Bi}$ & $1.60 E+04$ & $1.51 E+04$ \\
\hline $\mathrm{ZrO}(\mathrm{OH})_{2}$ & $1.99 E+03$ & $1.89 E+03$ \\
\hline $\mathrm{OH}^{-}$ & $1.97 E+04$ & $1.87 E+04$ \\
\hline $\mathrm{NO}_{3}{ }^{-1}$ & $4.86 E+03$ & $4.59 E+03$ \\
\hline $\mathrm{NO}_{2}^{-1}$ & $3.71 E+03$ & $3.51 E+03$ \\
\hline $\mathrm{SO}_{4}^{-2}$ & $2.67 E+03$ & $2.53 E+03$ \\
\hline $\mathrm{PO}_{4}^{-3}$ & $1.26 \mathrm{E}+05$ & $1.19 E+05$ \\
\hline $\mathrm{SiO}_{3}^{-2}$ & $5.83 E+03$ & $5.51 E+03$ \\
\hline$F^{-1}$ & $2.01 E++03$ & $1.90 E+03$ \\
\hline \multicolumn{3}{|c|}{ Radiological Constituents } \\
\hline Radionuclide & $\mu \mathrm{Ci} / \mathrm{g}$ & \\
\hline $239 / 240 \mathrm{Pu}$ & $4.45 \mathrm{E}-02$ & $0.70 \mathrm{Kg}$ \\
\hline${ }^{137} \mathrm{Cs}$ & 0.65 & $6.12 \mathrm{E}+02 \mathrm{Ci}$ \\
\hline${ }^{90} \mathrm{Sr}$ & 7.03 & $6.65 \mathrm{E}+03 \mathrm{Ci}$ \\
\hline
\end{tabular}

Other estimates of historic constituent concentrations exist, and two have been included in Appendix B for comparison. The TRAC Model (Jungfleisch, 1984) and the results of previous sampling efforts comprise these additional historic estimates. The historic inventory numbers reported in this Tank Characterization Report for the liquid in Tank 241-C110 are based on previous sampling results. These values are included in Table 5-6 as the Historic Tank Content Estimate for the liquid material. 


\subsection{SURVEILLANCE DATA}

\subsubsection{Surface Level Readings}

Tank $241-C-110$ is equipped with a manual tape gauge to determine the surface level of the waste. The manual tape uses a conductivity probe which is lowered by a hand crank until electrical contact is made with the waste surface and an electric circuit completed, providing the measurement. The operator records the manual tape's measurement and enters it into the Computer Automated Surveillance System (CASS).

The most recent manual tape reading for Tank 241-C-110 was 65 inches in February 1994 (Rios, 1994). Figure 2-5 illustrates the surface level readings from 1981 to the present. The readings are fairly consistent except for a significant drop in the last quarter of 1991 when Tank 241-C-110 was salt well pumped. Readings before 1981 are not included because the data has been archived and is not readily available on CASS.

\subsubsection{Internal Tank Temperatures}

Temperatures are taken in Tank 241-C-110 by a probe which enters the tank through riser 8 . The probe has 11 thermocouples which are arranged at different heights in the tank. Due to the waste level in the tank, six of the thermocouples are currently being used. The most recent temperature reading available was $66^{\circ} \mathrm{F}$ taken on May 19,1994 . This measurement is consistent with historical measurements of Tank 241-C-110. Plotted temperature readings of Tank 241-C-110 since 1988 can be found in Figure 2-6.

Tank $241-\mathrm{C}-110$ is classified as a semiannual tank, meaning that temperatures are collected in January and July. However, as shown on the temperature plot in Figure 2-6, there was a period between 1988 and 1991 when temperatures were not taken. It is not known why temperatures were not taken during this period. It is possible that temperatures were taken, but the data sheets were misplaced. Also, since being hooked up to the Temperature Monitoring and Control System (TMACS) on April 4, 1994, Tank 241-C-110 has been monitored continually. Temperature data from TMACS is currently downloaded to the Surveillance Analysis Computer System (SACS) once a day, but it is planned to reduce this downloading frequency to once a week.

As can be seen in Figure 2-6, the temperature reading for January 1994 is far below any other temperature readings for Tank 241-C-110. Because the reading is below $50^{\circ} \mathrm{F}$, its accuracy is immediately considered "suspect" by SACS. A re-check of the temperature was done a few days later which resulted in a measurement more consistent with historical data. Considering that the temperature of Tank 241-C-110 has historically been stable and that the re-check yielded a temperature in the expected range, it is reasonable to assume that the low measurement from January 1994 is a bad datum point, and can be discarded. 
Figure 2-5. Tank 241-C-110 Surface Level Readings.

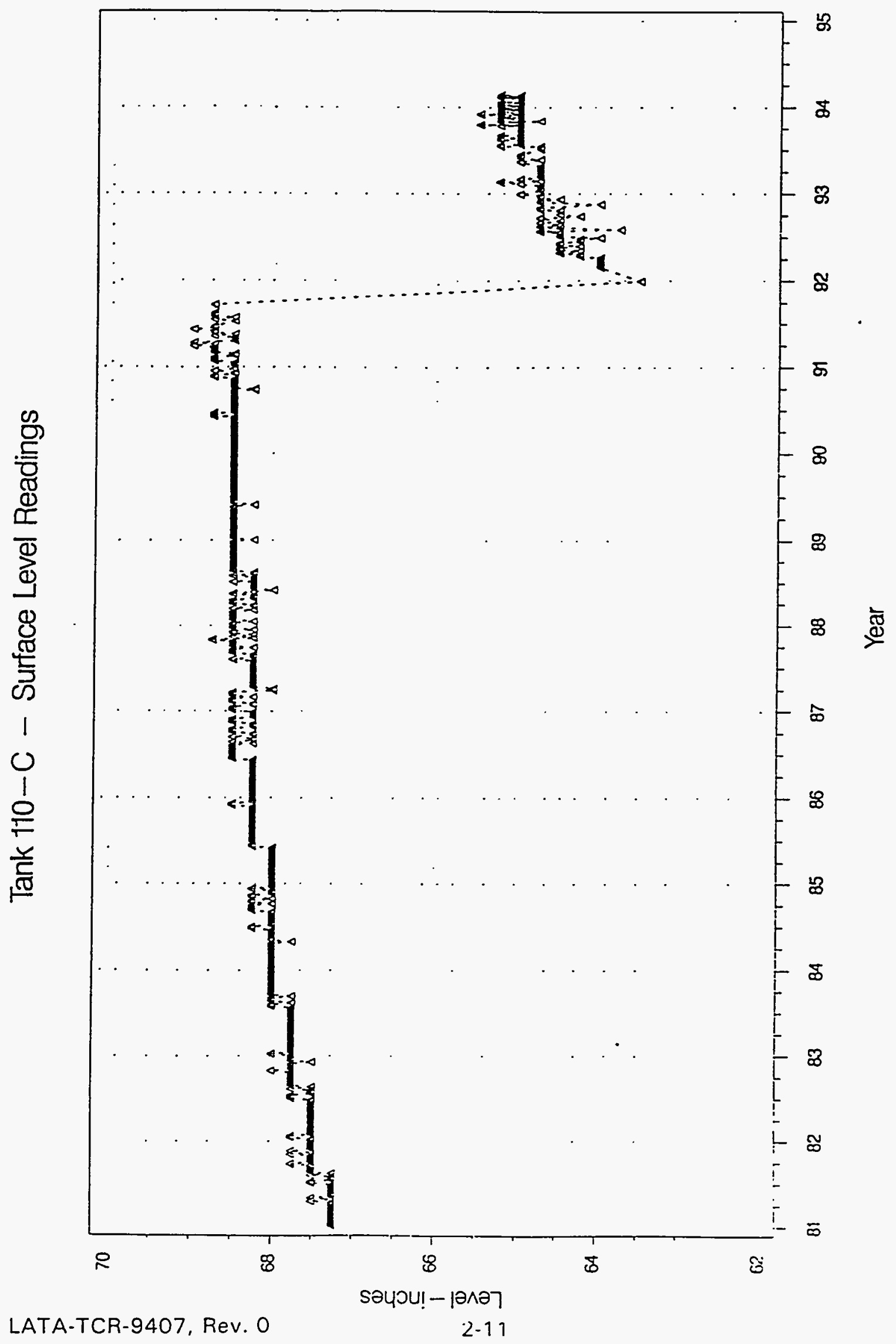


Figure 2-6. Tank 241-C-110 Temperatures Since 1988.

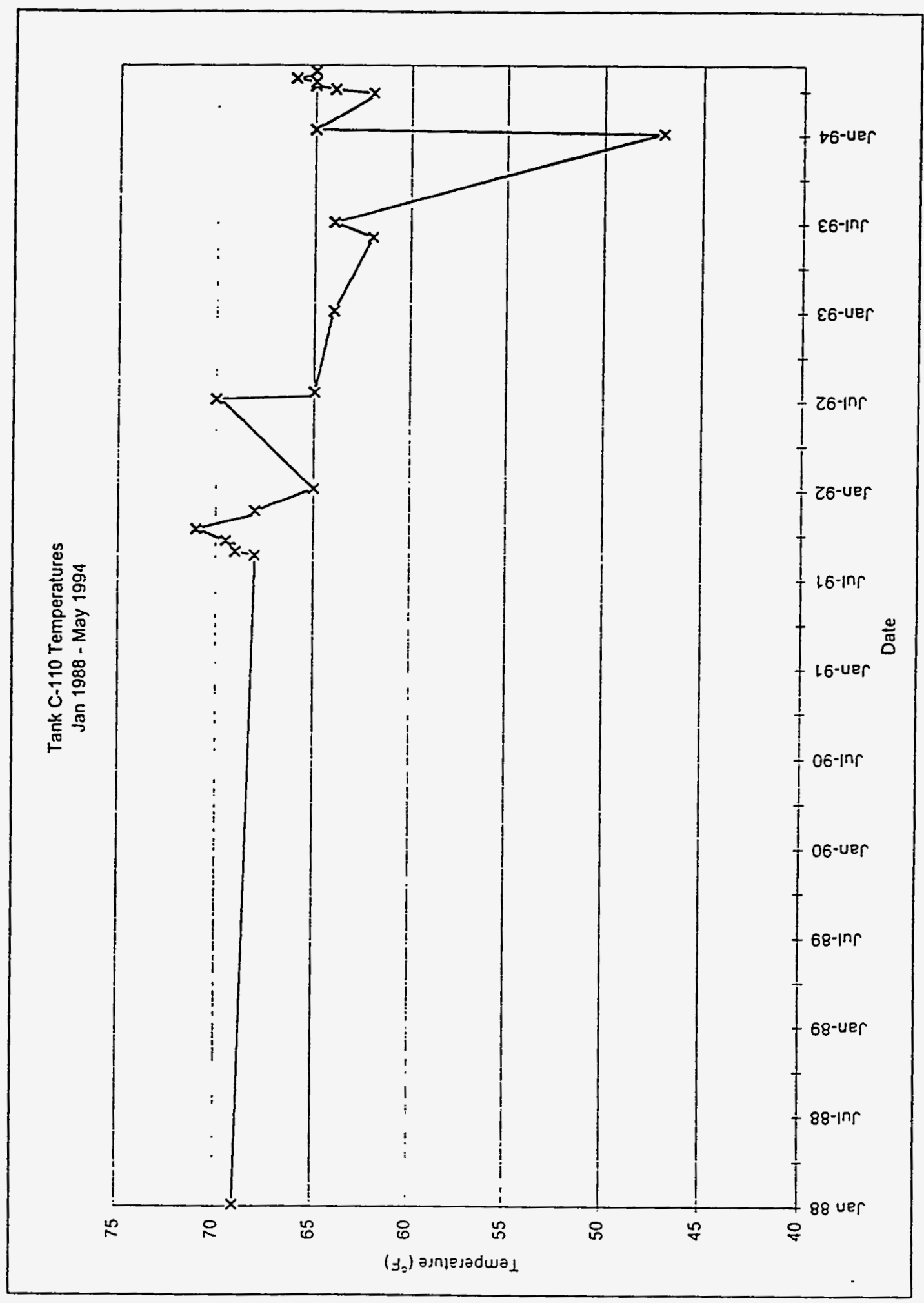




\subsection{TANK SAMPLING OVERVIEW}

The purpose of this section is to discuss the April 1992 sampling effort of Tank 241-C110. The sampling event is described first, followed by a discussion of the distribution of samples among analytical laboratories. The analyses requested from each laboratory and sample are included in detail.

\subsection{DESCRIPTION OF SAMPLING EVENT}

In 1992, Tank 241-C-110 was push mode core sampled from April 14 through April 23. A total of three core samples were taken, each consisting of four segments. Core 37 was taken through riser \#5, core 38 through riser \#7, and core 39 through riser \#2 (WHC, 1992). For a diagram of riser location, refer to Figure $2-2$ in the previous chapter.

The core samples from Tank 241-C-110 were obtained using a specially designed core sampling truck (CST) that has sampling equipment mounted on a rotating platform. The core sampling truck used a drill string to push through the waste. The sampler was located inside this drill string. When the drill string was pushed into the waste, the sampler was filled. Once the sampler had passed 19 in. through the waste, a spring-activated rotary valve trapped the segment of waste within the sampler. Each segment has a length of 19 in., a diameter of $7 / 8$ in., and a maximum volume of 187 milliliters. After the sampler was filled, it was extracted from the drill string and another sampler inserted. During sampler change out, kerosene range normal paraffin hydrocarbons were added to the drill string as a hydrostatic fluid to prevent the waste from backing up into the drill string. Because of the limitations of the core sampling equipment, the bottom three inches of waste in the tank were not sampled (Winters et al., 1990). For additional information concerning core sampling, see the Tank Characterization Reference Guide (De Lorenzo, et al., 1994).

Each segment-containing sampler was remotely removed from the drill string and sealed within a stainless steel liner, which was then placed inside a lead shielded shipping cask. The casks were then transported to the WHC 222-S Process and Analytical Laboratory. All segments were received by the laboratory on May 9, 1992. A chain-of-custody form was filled out for each segment.

\subsection{SAMPLE CUSTODY DATA}

A total of twelve segments from Tank 241-C-110 were received by the 222-S Laboratory. These segments were then divided into sub-samples and composites. Table 3-1 shows the sample distribution and custody data for the 222-S Laboratory. 
Table 3-1. WHC 222-S Laboratory Sample Custody Data. (2 pages)

\begin{tabular}{|c|c|c|c|c|}
\hline Core & Sample & $\begin{array}{l}\text { Tank } \\
\text { Farm } \\
\text { Sample } \\
\text { Number }\end{array}$ & $\begin{array}{c}\text { Date } \\
\text { Received } \\
\text { at } 222-S^{1}\end{array}$ & Laboratory ID Number \\
\hline 37 & Segment 1 & $92-007$ & $5 / 9 / 92$ & No Recovery \\
\hline 37 & Segment 2 & $92-008$ & $5 / 9 / 92$ & $\mathrm{~J} 582, \mathrm{~J} 583, \mathrm{~J} 589, \mathrm{~J} 738^{2}$ \\
\hline 37 & Segment 3 & $92-009$ & $5 / 9 / 92$ & No Recovery \\
\hline 37 & Segment 4 & $92-010$ & $5 / 9 / 92$ & $\mathrm{~J} 586, \mathrm{~J} 587, \mathrm{~J} 591, \mathrm{~J} 739^{2}$ \\
\hline 38 & Segment 1 & $92-011$ & $5 / 9 / 92$ & $\begin{array}{l}\mathrm{J} 592, \mathrm{~J} 593, \mathrm{~J} 612, \\
\mathrm{~J} 613, \mathrm{~J} 614, \mathrm{~J} 742^{2},\end{array}$ \\
\hline 38 & Segment 2 & $92-012$ & $5 / 9 / 92$ & No Recovery \\
\hline 38 & Segment 3 & $92-013$ & $5 / 9 / 92$ & No Recovery \\
\hline 38 & Segment 4 & $92-014$ & $5 / 9 / 92$ & $\mathrm{~J} 596, \mathrm{~J} 619, \mathrm{~J} 620, \mathrm{~J} 745^{2}$ \\
\hline 39 & Segment 1 & $92-015$ & $5 / 9 / 92$ & No Recovery \\
\hline 39 & Segment 2 & $92-016$ & $5 / 9 / 92$ & J599, J624, J625, J747² \\
\hline 39 & Segment 3 & $92-017$ & $5 / 9 / 92$ & $\mathrm{~J} 600, \mathrm{~J} 626, \mathrm{~J} 627, \mathrm{J748^{2 }}$ \\
\hline 39 & Segment 4 & $92-018$ & $5 / 9 / 92$ & $\mathrm{~J} 601, \mathrm{~J} 628, \mathrm{J629}, \mathrm{J} 749^{2}$ \\
\hline 38 & Segment 4 Homog. & & & J644, J645, J647, J649 \\
\hline \multirow[t]{2}{*}{39} & Segment 3 Homog. & & & J650, J652, J656, J658 \\
\hline & Composite Homog. & & & $\mathrm{J} 759, \mathrm{~J} 760, \mathrm{~J} 761, \mathrm{~J} 762$ \\
\hline 37 & Drainable Liquid & & & J779, J781, J782, J783 \\
\hline 38 & Drainable Liquid & & & J777, J778, J802, J803 \\
\hline \multirow[t]{2}{*}{39} & Drainable Liquid & & & $\mathrm{J} 772, \mathrm{~J} 773, \mathrm{~J} 774, \mathrm{~J} 775$ \\
\hline & $\begin{array}{l}\text { Drainable Liquid } \\
\text { Composite }\end{array}$ & & & $\begin{array}{l}\text { J795, J796, J797, J798, } \\
\text { J799, J800 }\end{array}$ \\
\hline 37 & Composite 1 & & & $\begin{array}{l}\text { J633, J634, J646, J651, } \\
\mathrm{J} 664, \mathrm{~J} 665, \mathrm{~J} 666, \mathrm{~J} 670, \\
\mathrm{~J} 671, \mathrm{~J} 674, \mathrm{~J} 689, \mathrm{~J} 690, \\
\mathrm{~J} 691, \mathrm{~J} 692, \mathrm{~J} 693, \mathrm{~J} 694, \\
\mathrm{~J} 713, \mathrm{~J} 714, \mathrm{~J} 715, \mathrm{~J} 726^{2} \\
\mathrm{~J} 732^{2}, \mathrm{~J} 753, \mathrm{~J} 979, \\
\mathrm{~J} 980, \mathrm{~J} 981, \mathrm{~J} 982, \mathrm{~J} 983\end{array}$ \\
\hline 37 & Composite 2 & & & $\begin{array}{l}\mathrm{J} 635, \mathrm{~J} 653, \mathrm{~J} 667, \mathrm{~J} 678, \\
\mathrm{~J} 695, \mathrm{~J} 704, \mathrm{~J} 716, \\
\mathrm{~J} 727^{2}, \mathrm{~J} 733^{2}, \mathrm{~J} 754\end{array}$ \\
\hline 38 & Composite 1 & & & $\begin{array}{l}\text { J636, J654, J655, J657, } \\
\text { J668, J669, J672, J675, } \\
\text { J679, J681, J682, J696, } \\
\text { J697, J698, J705, J706, } \\
J 707, J 717, J 718, J 719, \\
J 7282, J 734^{2}, J 755, \\
J 784, J 785, J 786\end{array}$ \\
\hline
\end{tabular}


Table 3-1. WHC 222-S Laboratory Sample Custody Data. (2 pages)

\begin{tabular}{|c|c|c|c|c|}
\hline Core & $\begin{array}{l}\text { Sample } \\
\quad \because\end{array}$ & $\begin{array}{c}\text { Tank } \\
\text { Farm } \\
\text { Sample } \\
\text { Number }\end{array}$ & $\begin{array}{c}\text { Date } \\
\text { Received } \\
\text { at } 222-S^{1}\end{array}$ & Laboratory ID Number \\
\hline 39 & Composite 1 & & & $\begin{array}{l}\mathrm{J} 639, \mathrm{~J} 660, \mathrm{~J} 661, \mathrm{~J} 662, \\
\mathrm{~J} 676, \mathrm{~J} 677, \mathrm{~J} 680, \mathrm{~J} 685, \\
\mathrm{~J} 686, \mathrm{~J} 687, \mathrm{~J} 700, \mathrm{~J} 701, \\
\mathrm{~J} 702, \mathrm{~J} 708, \mathrm{~J} 710, \mathrm{~J} 711, \\
\mathrm{~J} 721, \mathrm{~J} 722, \mathrm{~J} 723, \\
\mathrm{~J} 730^{2}, \mathrm{~J} 736^{2}, \mathrm{~J} 757, \\
\mathrm{~J} 788, \mathrm{~J} 789, \mathrm{~J} 972, \mathrm{~J} 973, \\
\mathrm{~J} 974, \mathrm{~J} 975, \mathrm{~J} 976, \mathrm{~J} 977\end{array}$ \\
\hline 39 & Composite 2 & & & $\begin{array}{l}J 640, J 663, J 683, J 688, \\
J 703, J 712, J 724, \\
J 731^{2}, J 737^{2}, J 758, \\
J 790, J 791\end{array}$ \\
\hline
\end{tabular}

${ }^{1}$ The only samples taken directly from the tank were the segments. All the other samples were created at 222-S from the original segments. Thus, only the segments have sample numbers and receipt dates.

${ }^{2}$ Indicates that this particular vial was shipped to PNL for analysis.

Some of the samples were sent to Battelle's Pacific Northwest Laboratory (PNL) for organic, isotopic Pu and $U$, rheology, and physical analyses. Table 3-2 presents the custody data concerning the samples transferred from the 222-S Laboratory to PNL.

A list of the analytes requested from the samples at the 222-S Laboratory is found in Table 3-3. Table 3-4 lists the analyses requested for the samples sent to PNL.

\subsection{PROBLEMS WITH THE SAMPLES}

The waste recovery for Tank 241-C-110 was relatively poor. As described in Table 3-5, five of the 12 segments were recovered with $100 \%$ recovery, four segments were empty, one segment had an $80 \%$ recovery, and two segments contained less than $50 \%$ recovery. Each core had at least one empty segment, and core 38 contained only segments 1 and 4. There were very few liquid recoveries in any of the samples. Only one segment from each core contained drainable liquids exceeding $15 \%$. Because of the poor recovery of the sampling effort and the poor mechanical performance of the sampling equipment for Tank 241-C-110, both from incomplete segments as well as unresolved segments, the results given later may be biased. The magnitude of this bias cannot be determined. 
Table 3-2. PNL Sample Custody Data.

\begin{tabular}{|c|c|c|c|c|}
\hline Core & Sample & ID Number & $\begin{array}{c}\text { PNL Sample } \\
\text { Number }\end{array}$ & $\begin{array}{c}\text { Date } \\
\text { Received }\end{array}$ \\
\hline 37 & Segment 2 & J738 & $92-11291$ & $9 / 24 / 92$ \\
\hline 37 & Segment 4 & J739 & $92-11292$ & $9 / 24 / 92$ \\
\hline 37 & Composite 1 & J726 & $92-08302$ & $6 / 24 / 92$ \\
\hline 37 & Composite 1 & J732 & $92-08303$ & $6 / 24 / 92$ \\
\hline 37 & Composite 2 & J727 & $92-08304$ & $6 / 24 / 92$ \\
\hline 37 & Composite 2 & J733 & $92-08305$ & $6 / 24 / 92$ \\
\hline 38 & Segment 1 & J742 & $92-08297$ & $6 / 24 / 92$ \\
\hline 38 & Segment 4 & $J 745$ & $92-08298$ & $6 / 24 / 92$ \\
\hline 38 & Composite 1 & J728 & $92-08306$ & $6 / 24 / 92$ \\
\hline 38 & Composite 1 & J734 & $92-08307$ & $6 / 24 / 92$ \\
\hline 39 & Segment 2 & $J 747$ & $92-08299$ & $6 / 24 / 92$ \\
\hline 39 & Segment 3 & $J 748$ & $92-08300$ & $6 / 24 / 92$ \\
\hline 39 & Segment 4 & J749 & $92-08301$ & $6 / 24 / 92$ \\
\hline 39 & Composite 1 & J730 & $92-08308$ & $6 / 24 / 92$ \\
\hline 39 & Composite 1 & $J 736$ & $92-08309$ & $6 / 24 / 92$ \\
\hline 39 & Composite 2 & $J 731$ & $92-08310$ & $6 / 24 / 92$ \\
\hline 39 & Composite 2 & J737 & $92-08311$ & $6 / 24 / 92$ \\
\hline-- & Hot Cell Blank & $J 762$ & $92-08312$ & $6 / 24 / 92$ \\
\hline 38 & Drainable Liquid & $J 795$ & $92-09437$ & $\cdots$ \\
\hline
\end{tabular}


Table 3-3. Samples and Requested Analytes for the 222-S Laboratory (McKinley, 1992 and Hill et al., 1991).

\begin{tabular}{|c|c|}
\hline Identification Numbers & Requested Analytes \\
\hline $\begin{array}{l}\mathrm{J} 666, \mathrm{~J} 667, \mathrm{~J} 672, \mathrm{~J} 680, \mathrm{~J} 683, \mathrm{~J} 691, \\
\mathrm{~J} 704, \mathrm{~J} 707, \mathrm{~J} 711, \mathrm{~J} 712, \mathrm{~J} 715, \mathrm{~J} 716, \\
\mathrm{~J} 719, \mathrm{~J} 723, \mathrm{~J} 724, \mathrm{~J} 775, \mathrm{~J} 778, \mathrm{~J} 783, \\
\mathrm{~J} 800, \mathrm{~J} 974\end{array}$ & $\begin{array}{l}\mathrm{Ag}, \mathrm{Al}, \mathrm{As}, \mathrm{Ba}, \mathrm{Be}, \mathrm{Bi}, \mathrm{Ca}, \mathrm{Cd}, \mathrm{Co}, \mathrm{Cr}, \mathrm{Cu}, \\
\mathrm{Fe}, \mathrm{K}, \mathrm{Mg}, \mathrm{Mn}, \mathrm{Na}, \mathrm{Ni}, \mathrm{Pb}, \mathrm{Sb}, \mathrm{Se}, \mathrm{Sn}, \mathrm{Tl} \\
\mathrm{V}, \mathrm{Zn}, \mathrm{Si}, \mathrm{The}, \mathrm{U}, \mathrm{Zr}, \mathrm{NH}_{3}\end{array}$ \\
\hline $\begin{array}{l}\mathrm{J} 694, \mathrm{~J} 695, \mathrm{~J} 698, \mathrm{~J} 702, \mathrm{~J} 703, \mathrm{~J} 775, \\
\mathrm{~J} 783, \mathrm{~J} 800, \mathrm{~J} 7778, \mathrm{~J} 635\end{array}$ & $\begin{array}{l}\mathrm{NO}_{3}^{-}, \mathrm{NO}_{2}^{-}, \mathrm{F}^{-}, \mathrm{Cl}^{-}, \mathrm{SO}_{4}^{-2}, \mathrm{PO}_{4}^{-3}, \mathrm{NO}_{2}^{-}, \\
\mathrm{CO}_{3}^{-2}, \mathrm{pH}^{-14} \mathrm{C},{ }^{3} \mathrm{H}, \text { specific gravity }\end{array}$ \\
\hline J674, J678, J682, J687, J688, J799 & $\mathrm{CN}^{-}$ \\
\hline $\begin{array}{l}\mathrm{J} 715, \mathrm{J716}, \mathrm{J719}, \mathrm{J} 723, \mathrm{~J} 724, \mathrm{~J} 775, \\
\mathrm{~J} 778, \mathrm{~J} 783, \mathrm{~J} 800\end{array}$ & $\begin{array}{l}\mathrm{U},{ }^{238.239 .240} \mathrm{Pu},{ }^{241} \mathrm{Am},{ }^{244} \mathrm{Cm},{ }^{237} \mathrm{~Np}, \\
{ }^{90} \mathrm{Sr},{ }^{99} \mathrm{Tc},{ }^{129}{ }_{1},{ }^{137} \mathrm{Cs},{ }^{79} \mathrm{Se} \text {, Total Alpha, } \\
\text { Total Beta }\end{array}$ \\
\hline $\begin{array}{l}\mathrm{J} 583, \mathrm{~J} 587, \mathrm{~J} 614, \mathrm{~J} 620, \mathrm{~J} 625, \mathrm{~J} 627, \\
\mathrm{~J} 629, \mathrm{~J} 786, \mathrm{~J} 789, \mathrm{~J} 791\end{array}$ & $\% \mathrm{H}_{2} \mathrm{O}$ \\
\hline $\begin{array}{l}\text { J589, J591， J593， J596, J599, J600, } \\
\text { J601， J634， J635, J636, J639， J640 }\end{array}$ & DSC, TGA \\
\hline J651, J653, J657, J663, J761 & $\mathrm{Hg}$ \\
\hline
\end{tabular}

Table 3-4. Samples and Requested Analyses For PNL (McKinley 1992).

\begin{tabular}{|c|c|l|}
\hline PNL Sample Number & Identification Number & Analyses Requested \\
\hline $92-11291$ & $\mathrm{~J} 738$ & Rheology and Physical \\
$92-11292$ & $\mathrm{~J} 739$ & \\
\hline $92-08302$ & $\mathrm{~J} 726$ & Pu and U Isotopic \\
$92-08304$ & $\mathrm{~J} 727$ & \\
$92-08306$ & $\mathrm{~J} 728$ & \\
$92-08308$ & $\mathrm{~J} 730$ & \\
$92-08310$ & $\mathrm{~J} 731$ & \\
$92-09437$ & $\mathrm{~J} 795$ & VOA \\
\hline $92-08297$ & $\mathrm{~J} 742$ & \\
$92-08298$ & $\mathrm{~J} 745$ & \\
$92-08299$ & $\mathrm{~J} 747$ & \\
$92-08300$ & $\mathrm{~J} 748$ & \\
$92-08301$ & $\mathrm{~J} 749$ & \\
\hline $92-08303$ & $\mathrm{~J} 732$ & \\
$92-08305$ & $\mathrm{~J} 733$ & \\
$92-08307$ & $\mathrm{~J} 334$ & \\
$92-08309$ & $\mathrm{~J} 336$ & \\
$92-08311$ & $\mathrm{~J} 337$ & \\
$92-09437$ & $\mathrm{~J} 795$ & \\
$92-08312$ & $\mathrm{J762}$ & \\
\hline
\end{tabular}


Table 3-5. Tank 241-C-110 Core Sample \% Recovery and Liquid/Solid Fraction.

\begin{tabular}{|c|c|c|c|}
\hline Core & Segment & $\%$ Recovery & $\begin{array}{l}\text { Liquid/Solid } \\
\text { Fraction }\end{array}$ \\
\hline \multirow[t]{4}{*}{37} & 1 & 0 & NA \\
\hline & 2 & 100 & All Solids \\
\hline & 3 & 100 & Alt Drainable Liquid \\
\hline & 4 & 100 & $85 \%$ Solids, $15 \%$ Liquids \\
\hline \multirow[t]{4}{*}{38} & 1 & 35 & $25 \%$ Solids, $10 \%$ Liquid \\
\hline & 2 & 0 & N/A \\
\hline & 3 & 0 & N/A \\
\hline & 4 & 100 & $50 \%$ Solids, $50 \%$ Liquid \\
\hline \multirow[t]{4}{*}{39} & 1 & 0 & N/A \\
\hline & 2 & 80 & $65 \%$ Solids, $15 \%$ Liquid \\
\hline & 3 & 25 & All Solids \\
\hline & 4 & 100 & All Solids \\
\hline
\end{tabular}

Four segments were recovered with the rotary valve left open: Core 38 , segments 1 , 2 , and 3 , and core 39, segment 1 . None of these segments contained waste sample except for core 38 , segment 1 , which contained $25 \%$ recovery (solid sludge). Mechanical failure of the core sampler is suspected as the cause of the segment recovery problems.

Core 37, segment 1 was also recovered without sample; however, the valve on the sampler was closed. It is possible, although unlikely, that the sampler had not yet reached the top of the waste. It is more probable that the lack of sample recovery was due to obstruction or mechanical failure of the sampler.

In some segments, the consistency of the waste was softer than in many of the other segments. A likely reason for this change in consistency is that the sample was saturated by the NPH. Core 37, segment 3; core 38, segment 4; and core 39, segments 2 and 3 all had excessively soft consistencies and are suspected of being subject to contamination. It is possible that this low recovery was a result of mechanical failure and subsequent NPH contamination. 


\subsection{SAMPLE HANDLING AND ANALYSIS SCHEME}

The object of these waste analyses is primarily to evaluate the waste in meeting requirements of the Hanford Federal Facility Agreement and Consent Order (Ecology, EPA \& $D O E, 1993)$. However, there are other benefits. First, this information will help to evaluate whether constituent concentrations are within safe operating limits. Second, constituent concentrations relevant to functional limits can be determined.

\subsection{WASTE DESCRIPTION}

The solids in the waste collected from Tank 241-C-110 were reddish brown and very homogenous. For the most part, the appearance and consistency of the solids were like "melting chocolate ice cream" (WHC, 1992); however, some of the solids were significantly softer and more fluid. The hot cell chemist hypothesized that the softer solids were caused by NPH saturation (WHC, 1992). The liquids in the samples were also reddish brown and opaque. From an in-tank photograph, other miscellaneous debris such as black tubing and discarded level measurement tapes could be seen on the tank waste surface (ICF Kaiser Hanford, 1994).

\subsection{HOLD TIME CONSIDERATIONS}

For information concerning hold times, see the Tank Characterization Reference Guide (De Lorenzo et al., 1994)

\subsection{SAMPLE PREPARATION}

Sample preparation procedures are conducted in order to optimize the recovery of each analyte of interest from the tank waste. Water, acid, and $\mathrm{KOH}$ Fusion digestions are commonly used to extract metals and several radioisotopes from solid samples, and in some cases digestions are performed on liquid samples to improve analytical matrices. Many separations are specific to a particular analysis and are described within the corresponding analytical method's referenced in Tables 4-2 and 4-3. In order to verify analyte recoveries resulting from separation techniques, laboratory control samples, carriers, tracers, and surrogates are routinely analyzed concurrently with the samples. For further discussion of sample preparation procedures, refer to the Tank Characterization Reference Guide (De Lorenzo et al., 1994).

\subsection{ANALYTICAL METHODS}

This section briefly describes the analyses used to characterize the waste in Tank 241 C-110. The analyses were split between the Westinghouse 222-S Laboratory and Battelle's Pacific Northwest Laboratory (PNL). 


\subsubsection{Physical and Rheological Tests}

Physical tests completed at the 222-Slaboratory included: thermogravimetric analyses (TGA), differential scanning calorimetry (DSC), specific gravity, and \%water analyses. Duplicate assays were performed for the \%water analyses. The physical properties measured at PNL included wt \% solids, settling behavior, and wt \% dissolved solids. Rheological testing was performed at PNL and included shear strength and shear stress as a function of shear rate. Rheological properties were measured in duplicate. Table 4-1 lists the analytical methods used for physical and rheological testing.

Table 4-1. Analytical Methods for Physical and Rheological Testing.

\begin{tabular}{|l|l|}
\hline \multicolumn{1}{|c|}{ Analyte } & \multicolumn{1}{|c|}{ Procedure } \\
\hline TGA & LA-560-112 \\
\hline DSC & LA-514-113 \\
\hline Specific Gravity & LA-510-112 \\
\hline$\%$ Water & LA-564-101 \\
\hline Rheology & PNL-ALO-501, PNL-ALO-502 \\
\hline Physical Properties & N/A \\
\hline
\end{tabular}

\subsubsection{Chemical and Radionuclide Constituent Analysis}

Most of the chemical and radionuclide analyses were performed at the 222-S Laboratory. The uranium and plutonium isotopic analyses, however, were performed at PNL. Duplicate analyses were performed on every tank sample. Table 4-2 lists the analytical methods used (Winters et al., 1993).

\subsubsection{Organic Constituent Analyses}

All organic analyses of the samples from Tank 241-C-110 were performed at PNL. The organic analyses performed were Volatile Organic Analyses (VOA), Semivolatile Organic Analyses (SVOA), Total Organic Halides (TOX), and Extractable Organic Halides (EOX). Duplicates were performed for all of these analyses. Table 4-3 lists the analyses and procedure numbers.

\subsection{MODULE SPECIFIC ANALYSES}

The characterization program for Tank 241-C-110 was intended to satisfy criteria set by the Tank Waste Remediation System (TWRS). The TWRS sample characterization objectives are to provide adequate description of physical, chemical, and radiological properties of Hanford Site tank wastes to support the resolution of Unreviewed Safety Questions, other safety issues surrounding the Watch List tanks, and the design of retrieval, pretreatment, and final disposal systems (Bell, 1994). For this specific tank, analyses to provide sufficient information to confidently determine whether constituent concentrations are within safe operating limits were performed. 
Table 4-2. Analytical Methods for Chemical and Radionuclide Analyses.

\begin{tabular}{|c|c|c|}
\hline Analyte & Method & Procedure Number \\
\hline $\mathrm{Hg}$ & Cold Vapor Atomic Absorption & LA-325-102 \\
\hline $\begin{array}{l}\mathrm{F}, \mathrm{Cl}^{-}, \mathrm{NO}_{3}^{-}, \mathrm{NO}_{2}^{-}, \mathrm{PO}_{4}{ }^{3-}, \\
\mathrm{SO}_{4}{ }^{2-}\end{array}$ & Ion Chromatography & LA-533-105 \\
\hline $\mathrm{CN}^{-}$ & Distillation/Spectrometric Analysis & $\begin{array}{l}\text { LA-695-101 } \\
\text { LA-695-102 }\end{array}$ \\
\hline$U$ & Laser Fluorimetry & LA-925-106 \\
\hline Total Alpha, Total Beta & Proportional Counting & LA-508-101 \\
\hline${ }^{238} \mathrm{Pu},{ }^{239,240} \mathrm{Pu},{ }^{241} \mathrm{Am}$ & Alpha Spectrometry & LA-503-156 \\
\hline${ }^{237} \mathrm{~Np}$ & Alpha Proportional Counting & LA-933-141 \\
\hline Total Metals & Inductively Coupled Plasma & LA-505-151 \\
\hline${ }^{90} \mathrm{Sr}$ & Beta Proportional Counting & LA-220-101 \\
\hline $\begin{array}{l}{ }^{99} \mathrm{Tc} \\
{ }^{79} \mathrm{Se}\end{array}$ & Liquid Scintillation & $\begin{array}{l}\text { LA-438-101 } \\
\text { LA-365-132 }\end{array}$ \\
\hline 129 & Low Energy Gamma Analysis & LA-378-104 \\
\hline${ }^{14} \mathrm{C}$ & Liquid Scintillation & $\begin{array}{l}\text { LA-348-104 } \\
\text { LA-218-114 }\end{array}$ \\
\hline $\begin{array}{l}{ }^{154} \mathrm{Eu},{ }^{155} \mathrm{Eu},{ }^{241} \mathrm{Am},{ }^{137} \mathrm{Cs}, \\
{ }^{60} \mathrm{Co}\end{array}$ & Gamma Energy Analysis & LA-548-121 \\
\hline $\mathrm{NO}_{2-}$ & Spectrophotometry & LA-645-001 \\
\hline $\mathrm{pH}$ & Electrode & LA-212-103 \\
\hline $\begin{array}{l}\text { As } \\
\text { Se }\end{array}$ & Hydride Atomic Absorption & $\begin{array}{l}\text { LA-355-131 } \\
\text { LA-365-131 }\end{array}$ \\
\hline Pu Isotopic & $\begin{array}{l}\text { Fusion } \\
\text { Mass Spectrometry }\end{array}$ & $\begin{array}{l}\text { PNL-ALO-423 } \\
\text { PNL-MA-597 } \\
\end{array}$ \\
\hline $\begin{array}{l}\text { U Isotopic } \\
\text { U Total }\end{array}$ & $\begin{array}{l}\text { Mass Spectrometry } \\
\text { Uranium Laser } \\
\end{array}$ & $\begin{array}{l}\text { PNL-MA-597 } \\
\text { PNL-ALO-445 } \\
\end{array}$ \\
\hline TOC & Total Organic Carbon & LA-344-105 \\
\hline $\mathrm{CO}_{3} / \mathrm{C}$ & Total Inorganic Carbon & LA-622-102 \\
\hline
\end{tabular}

Table 4-3. Analytical Methods For Organic Analyses.

\begin{tabular}{|c|l|l|}
\hline Analysis & \multicolumn{1}{|c|}{ Method } & Procedure Number \\
\hline VOA & Gas Chromatography/Mass Spectrometry & PNL-ALO-335 \\
\hline SVOA & Gas Chromatography/Mass Spectrometry & PNL-ALO-345 \\
\hline EOX & Microcoulometric Titration & PNL-ALO-320.2 \\
\hline TOX & Microcoulometric Titration & PNL-ALO-321 \\
\hline
\end{tabular}




\subsection{ANALYTICAL RESULTS AND WASTE INVENTORY}

The chemical, radiochemical, physical and organic results associated with Tank 241-C110 are presented within this document as indicated in Table 5-1. The samples from which these results were derived were collected between April 14 and April 23, 1992. This sampling event was the most recent regarding Tank 241-C-110 and the results reflected the most accurate characterization of the tank waste available at the present time.

Table 5-1. Analytical Data Presentation Tables.

\begin{tabular}{|l|l|}
\hline \multicolumn{1}{|c|}{ Analysis } & Tabulated Results \\
\hline $\begin{array}{l}\text { Tank Characterization Report Results for Total Solid } \\
\text { Material in Tank 241-C-110 }\end{array}$ & Table 5-5 \\
\hline $\begin{array}{l}\text { Tank Characterization Report Results for Liquid in } \\
\text { Tank 241-C-110 }\end{array}$ & Table 5-6 \\
\hline Metals & Table A-1 \\
\hline lons & Table A-2 \\
\hline Radionuclides & Table A-3 \\
\hline Physical Properties and Misc. Chemical Data & Table A-4 \\
\hline Volatile Organics & Table A-5 \\
\hline Semivolatile Organics & Table A-6 \\
\hline
\end{tabular}

The sample data presented in the Appendix A tables were obtained by calculating an average concentration value from the initial and duplicate analyses associated with each sample. If an analyte was detected during the original analysis but not the duplicate, or viceversa, only the detected result was recorded. When both sample runs failed to detect an analyte, the detection limit preceded by a less than $(<)$ sign was recorded as the sample result. Results which were determined to be estimated with respect to the data validation report were enclosed in parentheses, and a line was drawn through rejected results.

The Appendix A tables divide the laboratory data according to matrix, method of preparation, and method of analysis. The range of sample results is listed for each category. Statistically weighted means were either obtained from Remund and Jensen (1994), or calculated accordingly for all detected analytes obtained from core composite samples; these values were reported under the corresponding heading in the Appendix A tables. The weighted means were derived from a statistical model which allowed the results from each core to be weighted equally even though the analysis scheme involved the evaluation of two composite samples from cores 37 and 39 but only one composite sample from core 38 . A complete discussion regarding the methodology is presented in Remund and Jensen (1994). Non-weighted averages pertaining to the liquid sample data are reported in the "Evaluated Data Result" columns. When a set of samples failed to detect an analyte, the highest reported detection limit was recorded as the "Evaluated Data Result". 
The projected tank inventory value for drainable liquid in Tank 241-C-110 was calculated by multiplying the "Evaluated Data Result" by the volume of liquid in the tank at the time of sampling, 26,500 liters. With respect to the solid phase, the projected tank inventory was conservatively determined from the preferred analysis; that is, the digestion or analytical technique yielding the highest analyte concentration. The weighted mean of the preferred analysis was multiplied by $1,030,000$ kilograms, the mass of solid waste in the tank. The appropriate conversion factors were included in the calculations to obtain the reported units.

\subsection{CHEMICAL ANALYSES}

\subsubsection{Elemental Constituents}

According to the validation report, the results associated with $\mathrm{Bi}, \mathrm{Ce}, \mathrm{La}, \mathrm{P}, \mathrm{Sr}, \mathrm{S}, \mathrm{Sn}$, and $\mathrm{Zr}$ were rejected since the calibration verification standard solution utilized during the Inductively Coupled Plasma (ICP) runs did not include these analytes. However, sufficient spike and Laboratory Measurement Control System standard data were provided; therefore, the data was considered to be estimated as opposed to rejected for the purposes of this document.

The ICP analyses demonstrated that only phosphorous, sodium, and sulfur were present in the drainable liquid samples at concentrations above $1000 \mu \mathrm{g} / \mathrm{ml}$; sodium exhibited a value of $44,700 \mu \mathrm{g} / \mathrm{ml}$ and was, by far, the most abundant. As shown in Table 5-2, the levels of chromium, lead, and selenium found in the drainable liquid samples were considered to be high since their reported concentrations exceeded regulatory limits as defined by the Code of Federal Regulations (EPA, 1990). Furthermore, the results acquired from the analysis of solid samples by the Toxicity Characteristics Leaching Procedure (TCLP) were consistent with those obtained from drainable liquid samples as indicated in Table 5-2.

Table 5-2. Comparison of Drainable Liquid and TCLP Data.

\begin{tabular}{|l|c|c|c|}
\hline Analyte & $\begin{array}{c}\text { Drainable Liquid } \\
\text { Resuit } \\
(\mu \mathrm{g} / \mathrm{ml})\end{array}$ & $\begin{array}{c}\text { TCLP Result from } \\
\text { ICP } \\
(\mu \mathrm{g} / \mathrm{ml})\end{array}$ & $\begin{array}{c}\text { Regulatory Level } \\
(\mu \mathrm{g} / \mathrm{ml})\end{array}$ \\
\hline Chromium & 173 & 13.3 & 5.0 \\
\hline Selenium & 32.4 & 5.35 & 1.0 \\
\hline Lead & 5.37 & 1.23 & 5.0 \\
\hline
\end{tabular}

Inspection of Table 5-2 demonstrates that the ratios among chromium, selenium, and lead derived from the drainable liquid and TCLP analyses are somewhat similar.

The major constituents identified by ICP analysis with respect to the solid phase of the waste in Tank 241-C-110 were $\mathrm{Al}, \mathrm{Bi}, \mathrm{Ca}, \mathrm{Fe}, \mathrm{P}, \mathrm{Si}, \mathrm{Na}, \mathrm{S}$, and $\mathrm{U}$; all were present in concentrations exceeding $100 \mu \mathrm{g} / \mathrm{g}$. The historical estimates for $\mathrm{Al}, \mathrm{Bi}, \mathrm{Cr}, \mathrm{Fe}, \mathrm{Si}, \mathrm{Na}$, and $\mathrm{Zr}$ (ICF Kaiser Hanford, 1994) were available for comparison with the analytical data derived from core composite samples. The relative percent differences between the historical and 
analytical data associated with $\mathrm{Bi}, \mathrm{Cr}, \mathrm{Fe}$, and $\mathrm{Na}$ were less than $20 \% \mathrm{RPD}$; aluminum, zirconium, and silicon displayed relative percent differences of $82 \%, 153 \%$, and $160 \%$, respectively. Historical comparisons regarding phosphorus and sulfur are discussed in the following sections.

\subsubsection{Anions}

The most abundant anion in both the liquid and solid phases of the waste in Tank 241 C-110 was nitrate. Fluoride and phosphate were detected in greater concentrations in the solid samples as opposed to the liquid samples. On the other hand, the solid and liquid concentrations of chloride, nitrate, nitrite, and sulfate agreed to within $\pm 25 \%$. Cyanide was not detected in the solid portion of the waste, and its reported concentration from liquid samples was only $2.62 \mu \mathrm{g} / \mathrm{ml}$.

After converting the phosphorous and sulfur values derived from the ICP analyses into corresponding phosphate and sulfate data, the results were compared, as displayed in Table 5-3, to the phosphate and sulfate data obtained by ion chromatography (IC). Inspection of the table reveals a large difference between the solid phase phosphate data; therefore, it is surmised that precipitated phosphate salts account for the majority (approximately $92 \%$ ) of phosphorus in Tank 241-C-110. Furthermore, the concentration of phosphate contained within the solid phase of Tank 241-C-110 appears to be most accurately represented by the value calculated from the ICP data, and the historical data supports this claim.

Table 5-3. Comparison of ICP and IC Phosphate and Sulfate Results.

\begin{tabular}{|c|c|c|c|c|}
\hline \multirow{2}{*}{ Analyte } & \multicolumn{2}{|c|}{ Liquid Phase } & \multicolumn{2}{c|}{ Solid Phase } \\
\cline { 2 - 5 } & $\begin{array}{c}\text { IC Result } \\
(\mu \mathrm{g} / \mathrm{g})\end{array}$ & $\begin{array}{c}\text { ICP Result } \\
(\mu \mathrm{g} / \mathrm{g})\end{array}$ & $\begin{array}{c}\text { IC Result } \\
(\mu \mathrm{g} / \mathrm{g})\end{array}$ & $\begin{array}{c}\text { ICP Result } \\
(\mu \mathrm{g} / \mathrm{g})\end{array}$ \\
\hline Phosphate & 5070 & 5760 & 28100 & 62200 \\
\hline Sulfate & 11100 & 8120 & 14800 & 12200 \\
\hline
\end{tabular}

The historical estimates for nitrate, nitrite, phosphate, sulfate, and fluoride (ICF Kaiser Hanford, 1994) were available for comparison with the analytical data derived from core composite samples. The relative percent differences between the historical and analytical data associated with nitrate, sulfate, and fluoride ranged between 117 and $182 \%$; nitrite and phosphate displayed relative percent differences of approximately 60 and $68 \%$, respectively. The ICP derived phosphate value of $62200 \mu \mathrm{g} / \mathrm{g}$ was utilized for comparison since it offered the best correlation. The variations between analytical and historical data, although notable are not unexpected. The mobility and solubility properties of the ions in the waste, possible chemical changes in the waste over time, and incomplete and inconsistent recordkeeping contribute to the observed differences between analytical and historical data. 


\subsection{RADIOLOGICAL DETERMINATIONS}

The following radionuclides demonstrated activities above their corresponding detection limits when the drainable liquid samples from Tank $241-\mathrm{C}-110$ were analyzed: ${ }^{14} \mathrm{C},{ }^{137} \mathrm{Cs}$, ${ }^{239 / 240} \mathrm{Pu},{ }^{79} \mathrm{Se},{ }^{90} \mathrm{Sr},{ }^{99} \mathrm{TC},{ }^{3} \mathrm{H}$, and ${ }^{238} \mathrm{U}$. With the exception of ${ }^{79} \mathrm{Se}$, the previously cited isotopes demonstrated detectable activities in the core composite samples as well. As a note, ${ }^{238} \mathrm{U}$ activity was calculated from the laser fluorimetry data, as opposed the isotopic analysis.

The major radioactive constituents in both matrices were ${ }^{137} \mathrm{Cs}$ and ${ }^{90} \mathrm{Sr}$. The solid phase of the waste was predicted to yield a ${ }^{90} \mathrm{Sr}$ activity of $7.03 \mu \mathrm{Ci} / \mathrm{g}$ according to historical records, and the analytically determined value was $5.00 \mu \mathrm{Ci} / \mathrm{g}$. The historical estimate of ${ }^{137} \mathrm{Cs}$ activity, however, was not nearly as accurate; $0.65 \mu \mathrm{Ci} / \mathrm{g}$ compared to the laboratory value of $19.5 \mu \mathrm{Ci} / \mathrm{g}$.

\subsection{ORGANIC CONSTITUENTS}

None of the target analytes associated with the volatile and semivolatile organic analyses were detected, as indicated by Tables A-5 and A-6, during the evaluation of samples from Tank 241-C-110. Because of their volatile nature and relatively small contribution to the waste as indicated by the historical records, the appearance of these compounds was not expected. However, tributylphosphate was detected as a tentatively identified compound in the waste samples, and its presence is consistent with the fill history of the tank. Contamination resulting from the sampling process caused several normal paraffin hydrocarbons to appear as tentatively identified compounds during the sample analyses, and a reaction between the waste matrix and the organic surrogate compounds lead to the detection of nitration reaction products. These compounds, however, were not indigenous to the tank, and do not contribute substantially to the overall inventory of the tank. The reported concentration of tributyl phosphate cannot account for the total organic carbon in Tank 241-C-110; therefore, the bulk of organic carbon is assumed to be due to the presence of complexants.

Since inorganic carbon was detected in the core composite samples but not the drainable liquid, the data indicates that the carbonate in Tank 241-C-110 exists in the form of precipitated salt. The average amount of total inorganic carbon in the tank, $2030 \mu \mathrm{g} / \mathrm{g}$, translates into an average carbonate concentration of $10200 \mu \mathrm{g} / \mathrm{g}$.

\subsection{PHYSICAL MEASUREMENTS}

The physical properties of segments 2 and 4 of core 37 were extensively analyzed by PNL, and a summary of the results are presented in Table 5-4 (McKinley et al., 1992). Physical property data resulting from analyses conducted by the 222-S Laboratory are listed in Appendix A.

\subsubsection{Specific Gravity}

The specific gravity of the drainable liquid in Tank 241-C-110 was determined to be 1.09 as revealed by the data in Table A-4, and this value compares reasonably well with the density of centrifuged supernate data in Table 5-4. Density of the solid phase of the waste is also presented in Table 5-4.

LATA-TCR-9407, Rev. O $5-4$ 
Table 5-4. Physical Properties Obtained from Core 37.

\begin{tabular}{|c|c|c|}
\hline Property & Segment 2 & Segment 4 \\
\hline $\begin{array}{l}\text { Centrifuged Solids } \\
\text { (vol\%) } \\
\text { (wt \%) }\end{array}$ & $\begin{array}{l}75.5 \\
80.0\end{array}$ & $\begin{array}{l}76.2 \\
81.6\end{array}$ \\
\hline $\begin{array}{l}\text { Density }(\mathrm{g} / \mathrm{ml}) \\
\text { Sample } \\
\text { Cent. Supernate } \\
\text { Cent. Solid }\end{array}$ & $\begin{array}{l}1.41 \\
1.15 \\
1.49\end{array}$ & $\begin{array}{l}1.48 \\
1.13 \\
1.59 \\
\end{array}$ \\
\hline Wt\% Solids & 40.3 & 28.4 \\
\hline Wt\% Undissolved Solids & 35.3 & 20.3 \\
\hline Viscosity & $\leq 5 \mathrm{cP}$ & $\leq 5 \mathrm{cP}$ \\
\hline Shear Strength & $5,000 \pm 2,000$ dynes $/ \mathrm{cm}^{2}$ & $5,000 \pm 2,000$ dynes $/ \mathrm{cm}^{2}$ \\
\hline
\end{tabular}

\subsubsection{Percent Water}

All core and segment data pertaining to Tank 241-C-110 show that the waste is approximately $60 \%$ water. The only discrepancy with this claim arises from the weight percent solids result derived by the PNL laboratory for segment 4 of core $37,81.6 \%$ (Table 5-41; the 222-S Laboratory found this segment to be $58.6 \%$ water.

\subsubsection{Rheology}

The Pacific Northwest Laboratory reported the shear strength of the segment samples from core 37 to be $5000 \pm 2200$ dynes $/ \mathrm{cm}^{2}$. The analyses of shear stress as a function of shear rate conducted on non-diluted segment samples did not yield valid data due to drying of samples. At ambient temperature, shear stress peaks were observed at low shear rates, but shear stress decreased as shear rates continued to increase. At $95^{\circ} \mathrm{C}$ the samples dried before the measurement could be completed, and the shear stress increased as sample moisture was lost.

Rheological properties were evaluated in duplicate on $1: 1$ and $3: 1$ water/segment dilutions of segment samples 2 and 4 of core 37 at both ambient temperature and at $95^{\circ} \mathrm{C}$. At shear rates ranging between 200 and $500 \mathrm{hz}$, all of the diluted samples exhibited viscosities of 5 centipoise or less; the detection limit was 2 centipoise. The viscosity of the samples decreased as a function of rising temperatures.

\subsubsection{Energetics}

Exotherms were not observed in any of the tank waste samples during the differential scanning calorimetry analyses. 


\subsection{DATA PRESENTATION}

The Tank Characterization Report Results recorded in Tables 5-5 and 5-6 are the final constituent inventory estimates for this document. The values are equal to either the "Weighted Mean" or "Evaluated Data Result" values presented in the Appendix A tables, whichever is greater. Exceptions have either been previously or are subsequently discussed in this text. If laboratory results were not available for an analyte, the Tank Characterization Result was, if possible, derived from historical data.

Table 5-5. Tank Characterization Report Data for Total Solid Material in Single-Shell Tank 241-C-110. (3 pages)

\begin{tabular}{|c|c|c|c|}
\hline Analyte & $\begin{array}{c}\text { Historic Tank } \\
\text { Content } \\
\text { Estimate }\end{array}$ & $\begin{array}{c}\text { Tank } \\
\text { Characterization } \\
\text { Report Result }\end{array}$ & $\begin{array}{c}\text { Total } \\
\text { Tank } \\
\text { Inventory }\end{array}$ \\
\hline Metals & $(\mu g / g)$ & $(\mu g / g)$ & $(\mathrm{kg})$ \\
\hline Aluminum (Al) & 6,060 & 14,500 & 14,900 \\
\hline Antimony (Sb) & -- & 301 & 309 \\
\hline Arsenic (As) & -- & 4.11 & 4.22 \\
\hline Barium (Ba) & -- & 8.52 & 8.75 \\
\hline Beryllium (Be) & $\cdots$ & 0.287 & 0.295 \\
\hline Bismuth (Bi) & 16,000 & 16,800 & 17,200 \\
\hline Boron $(B)$ & $-\cdots$ & 25.0 & 25.7 \\
\hline Cadmium $(\mathrm{Cd})$ & $\cdots$ & 5.36 & 5.50 \\
\hline Calcium (Ca) & $-\cdots$ & 1,150 & 1,180 \\
\hline Cerium $(\mathrm{Ce})$ & $\cdots$ & 210 & 216 \\
\hline Chromium $(\mathrm{Cr})$ & 568 & 470 & 483 \\
\hline Cobalt (Co) & -- & 6.59 & 6.77 \\
\hline Copper (Cu) & -- & 98.9 & 102 \\
\hline Iron (Fe) & 9,150 & 11,000 & 11,300 \\
\hline Lanthanum (La) & $\cdots$ & 2.00 & 2.05 \\
\hline Lead $(\mathrm{Pb})$ & $\cdots$ & 258 & 265 \\
\hline Magnesium (Mg) & -- & 153 & 157 \\
\hline Manganese (Mn) & -- & 56.3 & 57.8 \\
\hline Mercury $(\mathrm{Hg})$ & -- & 0.450 & 0.462 \\
\hline Molybdenum (Mo) & -- & $\cdots$ & $\cdots$ \\
\hline Neptunium (Np) & $\cdots$ &.-- & $\cdots$ \\
\hline Nickel (Ni) & -- & 23.9 & 24.5 \\
\hline
\end{tabular}


Table 5-5. Tank Characterization Report Data for Total Solid Material in Single-Shell Tank 241-C-110. (3 pages)

\begin{tabular}{|c|c|c|c|}
\hline Analyte & $\begin{array}{c}\text { Historic Tank } \\
\text { Content } \\
\text { Estimate }\end{array}$ & $\begin{array}{c}\text { Tank } \\
\text { Characterization } \\
\text { Report Result }\end{array}$ & $\begin{array}{c}\text { Total } \\
\text { Tank } \\
\text { Inventory }\end{array}$ \\
\hline Metals (continued) & $(\mu g / g)$ & $(\mu \mathrm{g} / \mathrm{g})$ & $(\mathrm{kg})$ \\
\hline Phosphorus (P) &.-- & 20,300 & 20,800 \\
\hline Plutonium (Pu) & --- & - & --- \\
\hline Potassium (K) & $\cdots$ & 557 & 572 \\
\hline Selenium (Se) & $\ldots$ & 107 & 110 \\
\hline Silicon (Si) & 804 & 7,160 & 7,350 \\
\hline Silver (Ag) & $\ldots$ & 1.05 & 1.08 \\
\hline Sodium ( $\mathrm{Na}$ ) & 100,000 & 82,600 & 84,800 \\
\hline Strontium (Sr) & $\cdots$ & 131 & 134 \\
\hline Sulfur (S) & $\cdots$ & 4,080 & 4,190 \\
\hline $\operatorname{Tin}(S n)$ & --- & 12.8 & 13.1 \\
\hline Titanium (Ti) & -- & 10.5 & 10.8 \\
\hline Uranium (U) & -- & 1,480 & 1,520 \\
\hline Vanadium (V) & --- & 6.17 & 6.33 \\
\hline Zinc $(Z n)$ & --- & 224 & 230 \\
\hline Zirconium $(Z r)$ & 1,290 & 172 & 177 \\
\hline lons & $(\mu \mathrm{g} / \mathrm{g})$ & $(\mu g / g)$ & $(\mathrm{kg})$ \\
\hline Ammonia $\left(\mathrm{NH}_{3}\right)$ & --- & $<4,500$ & $<4,620$ \\
\hline Chloride $\left(\mathrm{Cl}^{-}\right)$ & $\cdots$ & 1,060 & 1,090 \\
\hline Cyanide $\left(\mathrm{CN}^{-}\right)$ & $\cdots$ & $<5.00$ & $<5.13$ \\
\hline Fluoride $\left(F^{*}\right)$ & 2,010 & 7,630 & 7,830 \\
\hline Hydroxide $\left(\mathrm{OH}^{-}\right)$ & 19,700 & $\cdots$ & -- \\
\hline Nitrate $\left(\mathrm{NO}_{3}{ }^{-}\right)$ & 4,860 & 110,000 & 114,000 \\
\hline Nitrite $\left(\mathrm{NO}_{2}^{-}\right)$ & 3,710 & 6,890 & 7.070 \\
\hline Phosphate $\left(\mathrm{PO}_{4}{ }^{3-}\right)$ & 126,000 & 28.100 & 28,800 \\
\hline Sulfate $\left(\mathrm{SO}_{4}{ }^{2-}\right)$ & 2,670 & 14,800 & 15,200 \\
\hline Radionuclides & $(\mu \mathrm{Ci} / \mathrm{g})$ & $(\mu \mathrm{Ci} / \mathrm{g})$ & (Ci) \\
\hline${ }^{241} \mathrm{Am}$ & -- & $<0.280$ & $<287$ \\
\hline${ }^{14} \mathrm{C}$ & $\cdots$ & 4.59E-04 & 0.471 \\
\hline${ }^{137} \mathrm{Cs}$ & 0.65 & 19.5 & 20,000 \\
\hline
\end{tabular}


Table 5-5. Tank Characterization Report Data for Total Solid Material in Single-Shell Tank 241-C-110. (3 pages)

\begin{tabular}{|c|c|c|c|}
\hline Analyte & $\begin{array}{c}\text { Historic Tank } \\
\text { Content } \\
\text { Estimate }\end{array}$ & $\begin{array}{c}\text { Tank } \\
\text { Characterization } \\
\text { Report Result }\end{array}$ & $\begin{array}{c}\text { Total } \\
\text { Tank } \\
\text { Inventory }\end{array}$ \\
\hline Radionuclides (continued) & $(\mu \mathrm{Ci} / \mathrm{g})$ & $(\mu \mathrm{Ci} / \mathrm{g})$ & $(\mathrm{Ci})$ \\
\hline${ }^{60} \mathrm{Co}$ & -- & $<0.0433$ & $<44.5$ \\
\hline${ }^{154} \mathrm{Eu}$ & -- & $<0.120$ & $<123$ \\
\hline${ }^{155} \mathrm{Eu}$ & -- & $<0.122$ & $<125$ \\
\hline 129 & -- & $<0.0250$ & $<25.7$ \\
\hline${ }^{237} \mathrm{~Np}$ & -- & $<0.0541$ & $<55.6$ \\
\hline${ }^{238} \mathrm{Pu}$ & --- & $<0.0498$ & $<51.1$ \\
\hline $239 / 240 \mathrm{Pu}$ & 0.0445 & 0.0802 & 82.4 \\
\hline${ }^{79} \mathrm{Se}$ & -- & 0.00130 & 1.34 \\
\hline${ }^{90} \mathrm{Sr}$ & 7.03 & 5.00 & 5,140 \\
\hline${ }^{99} \mathrm{Tc}$ & $\ldots$ & 0.0328 & 33.7 \\
\hline${ }^{3} \mathrm{H}$ & $\cdots$ & 0.00118 & 1.21 \\
\hline${ }^{238} \mathrm{U}$ & -- & 4.95E-04 & 0.508 \\
\hline Total Alpha & --- & 0.125 & 128 \\
\hline Total Beta & -- & 42.4 & 43,500 \\
\hline Physical Properties & & & $\mathrm{kg}$ \\
\hline Water & 68.4 & $59.8 \%$ & -- \\
\hline $\mathrm{pH}$ & --- & 11.0 & -- \\
\hline Specific Gravity & 1.34 & 1.45 & --- \\
\hline Thermogravimetric Analysis & -- & $57.5 \%$ & --- \\
\hline TIC & $\cdots$ & $2,030 \mu \mathrm{g} / \mathrm{mL}$ & 1,440 \\
\hline TOC & $\cdots$ & $802 \mu \mathrm{g} / \mathrm{g}$ & 823 \\
\hline
\end{tabular}


Table 5-6. Tank Characterization Report Data for Liquid in Single-Shell Tank 241-C-110. (3 pages)

\begin{tabular}{|c|c|c|}
\hline$\therefore \quad$ Analyte & $\begin{array}{c}\text { Tank Characterization } \\
\text { Report Result }\end{array}$ & $\begin{array}{l}\text { Total Tank } \\
\text { Inventory }\end{array}$ \\
\hline Metals & $\dot{\psi} \mathrm{g} / \mathrm{ml})$ & (kg) \\
\hline Aluminum (Al) & 87.9 & 2.33 \\
\hline Antimony (Sb) & 23.2 & 0.615 \\
\hline Arsenic (As) & 1.94 & 0.0514 \\
\hline Barium (Ba) & $<0.303$ & $<0.00803$ \\
\hline Beryllium (Be) & 0.190 & 0.00504 \\
\hline Bismuth (Bi) & 63.5 & 1.68 \\
\hline Boron (B) & 15.7 & 0.416 \\
\hline Cadmium $(\mathrm{Cd}\rangle$ & 0.443 & 0.0117 \\
\hline Calcium (Ca) & 17.2 & 0.456 \\
\hline Cerium (Ce) & 6.20 & 0.164 \\
\hline Chromium (Cr) & 173 & 4.58 \\
\hline Cobalt (Co) & 0.649 & 0.0172 \\
\hline Copper (Cu) & 1.76 & 0.0466 \\
\hline Iron $(\mathrm{Fe})$ & 47.3 & 1.25 \\
\hline Lanthanum (La) & 1.01 & 0.0268 \\
\hline Lead $(\mathrm{Pb})$ & 5.37 & 0.142 \\
\hline Magnesium (Mg) & 1.39 & 0.0368 \\
\hline Manganese (Mn) & 0.287 & 0.00761 \\
\hline Mercury $(\mathrm{Hg})$ & 0.111 & 0.00281 \\
\hline Molybdenum (Mo) & $\cdots$ & $\cdots$ \\
\hline Neptunium & $\cdots$ & $\cdots$ \\
\hline Nickel (Ni) & 1.16 & 0.0307 \\
\hline Phosphorus (P) & 2,050 & 54.3 \\
\hline Plutonium (Pu) & -- & $\cdots$ \\
\hline Potassium (K) & 436 & 11.6 \\
\hline Selenium (Se) & 32.4 & 0.859 \\
\hline Silicon (Si) & 65.5 & 1.74 \\
\hline Silver $(\mathrm{Ag})$ & 0.798 & 0.0211 \\
\hline Sodium (Na) & 44,700 & 1,190 \\
\hline Strontium $(\mathrm{S} r)$ & 0.807 & 0.0214 \\
\hline
\end{tabular}


Table 5-6. Tank Characterization Report Data for Liquid in Single-Shell Tank 241-C-110. (3 pages)

\begin{tabular}{|c|c|c|}
\hline Analyte & $\begin{array}{c}\text { Tank Characterization } \\
\text { Report Result }\end{array}$ & $\begin{array}{l}\text { Total Tank } \\
\text { Inventory }\end{array}$ \\
\hline Metals (cont.) & $(\mu \mathrm{g} / \mathrm{ml})$ & (kg) \\
\hline Sulfur (S) & 2,950 & 78.2 \\
\hline $\operatorname{Tin}(S n)$ & 1.45 & 0.0384 \\
\hline Titanium (Ti) & 0.253 & 0.00670 \\
\hline Uranium $\langle U\rangle$ & 322 & 8.53 \\
\hline Vanadium (V) & 1.61 & 0.0427 \\
\hline Zinc $(Z n)$ & 1.58 & 0.0419 \\
\hline Zirconium $(\mathrm{Zr})$ & 0.575 & 0.0152 \\
\hline lons & $(\mu \mathrm{g} / \mathrm{ml})$ & $(\mathrm{kg})$ \\
\hline Ammonia $\left(\mathrm{NH}_{3}\right)$ & 86.4 & 2.29 \\
\hline Chloride $\left(\mathrm{Cl}^{-}\right)$ & 996 & 26.4 \\
\hline Cyanide $\left(\mathrm{CN}^{-}\right)$ & 2.62 & 0.0694 \\
\hline Fluoride $\left(\mathrm{F}^{-}\right)$ & 516 & 13.7 \\
\hline Nitrate $\left(\mathrm{NO}_{3}{ }^{-}\right)$ & 90,800 & 2,410 \\
\hline Nitrite $\left(\mathrm{NO}_{2}^{-}\right)$ & 7,850 & 208 \\
\hline Phosphate $\left(\mathrm{PO}_{4}{ }^{3-}\right)$ & 5,530 & 147 \\
\hline Sulfate $\left(\mathrm{SO}_{4}{ }^{2-}\right)$ & 11,100 & 294 \\
\hline Radionuclides & $(\mu \mathrm{Ci} / \mathrm{ml})$ & (Ci) \\
\hline${ }^{241} \mathrm{Am}$ & $<0.0516$ & $<1.37$ \\
\hline${ }^{14} \mathrm{C}$ & $1.99 E-04$ & 0.00527 \\
\hline${ }^{137} \mathrm{Cs}$ & 7.98 & 211 \\
\hline${ }^{60} \mathrm{Co}$ & $<0.00720$ & $<0.191$ \\
\hline${ }^{154} \mathrm{Eu}$ & $<0.0192$ & $<0.509$ \\
\hline${ }^{155} \mathrm{Eu}$ & $<0.0216$ & $<0.572$ \\
\hline $129 \mid$ & $<2.38 \mathrm{E}-05$ & $<0.0211$ \\
\hline${ }^{237} \mathrm{~Np}$ & $<6.49 \mathrm{E}-05$ & $<0.0574$ \\
\hline${ }^{238} \mathrm{Pu}$ & $<9.00 \mathrm{E}-06$ & $<1.59 \mathrm{E}-04$ \\
\hline${ }^{239 / 240} \mathrm{Pu}$ & 0.00176 & 0.0466 \\
\hline${ }^{79} \mathrm{Se}$ & 6.17E-05 & 0.00163 \\
\hline${ }^{90} \mathrm{Sr}$ & 0.0278 & 0.737 \\
\hline${ }^{99} \mathrm{Tc}$ & 0.0162 & 0.429 \\
\hline
\end{tabular}


Table 5-6. Tank Characterization Report Data for Liquid in Single-Shell Tank 241-C-110. (3 pages)

\begin{tabular}{|c|c|c|}
\hline Analyte & $\begin{array}{c}\text { Tank Characterization } \\
\text { Report Result }\end{array}$ & $\begin{array}{l}\text { Total Tank } \\
\text { Inventory }\end{array}$ \\
\hline Radionuclides (continued) & $(\mu \mathrm{Ci} / \mathrm{ml})$ & (Ci) \\
\hline${ }^{3} \mathrm{H}$ & 7.18E-04 & 0.0190 \\
\hline${ }^{238} U$ & 2.59E-06 & $6.86 \mathrm{E}-05$ \\
\hline Total Alpha & 7.02E-04 & 0.186 \\
\hline Total Beta & 3.76 & 99.6 \\
\hline Physical Properties & & kg \\
\hline Water & -- & --- \\
\hline $\mathrm{pH}$ & 10.4 & $-\cdots$ \\
\hline Specific Gravity & 1.09 & $\cdots$ \\
\hline Thermogravimetric Analysis & $-\cdots$ & $\cdots$ \\
\hline TIC & $<543 \mu \mathrm{g} / \mathrm{mL}$ & $<53.8$ \\
\hline TOC & $592 \mu \mathrm{g} / \mathrm{ml}$ & 15.7 \\
\hline
\end{tabular}




\subsection{ANALYTICAL RESULTS INTERPRETATION}

\subsection{TANK WASTE PROFILE}

Examination of the analytical results reveals that the waste in Tank $241-C-110$ is $96 \%$ solids and $4 \%$ drainable liquids by mass. The sludge is composed of approximately $40 \%$ solids and $60 \%$ water. Sodium and nitrate ions were the major constituents present in the liquid phase of the tank. With respect to the solid phase of the waste, water was the single most significant compound with the following elements and anions demonstrating abundance: $\mathrm{Al}, \mathrm{Bi}, \mathrm{Ca}, \mathrm{Fe}, \mathrm{Na}, \mathrm{U}, \mathrm{NO}_{3}{ }^{\circ}$, and $\mathrm{PO}_{4}^{-3}$. The major radioactive constituents in both matrices were ${ }^{137} \mathrm{Cs}$ and ${ }^{90} \mathrm{Sr}$. The only organic constituent found in the tank was tributylphosphate.

An inventory of the composition of neutralized first cycle waste is presented in Table 6-1. Upon evaluation of the analytical data and inspection of Table 6-1, precipitated phosphate salts, such as bismuth phosphate, are expected to contribute to the solid phase of the waste in 241-C-110. Furthermore, the high ionic contents of the liquid in Tank 241-C110 would also allow the precipitation of sulfate, hexafluorosilicate, and nitrate salts originating from first cycle waste as well.

Table 6-1. Neutralized First Cycle Waste Composition (Schneider, 1951 ).

\begin{tabular}{|l|c|}
\hline \multicolumn{1}{|c|}{ Chemical } & Percent (wt) \\
\hline $\mathrm{Bi}^{+3}$ & 0.24 \\
\hline $\mathrm{Ce}^{+4}$ & 0.003 \\
\hline $\mathrm{Zr}^{+4}$ & 0.003 \\
\hline $\mathrm{Fe}^{+3}$ & 0.13 \\
\hline $\mathrm{Cr}^{+3}$ & 0.02 \\
\hline$\left(\mathrm{NH}_{4}\right)^{+}$ & 0.18 \\
\hline $\mathrm{Na}^{+}$ & 4.3 \\
\hline $\mathrm{SiF}_{6}^{-2}$ & 0.40 \\
\hline $\mathrm{PO}_{4}{ }^{-3}$ & 2.4 \\
\hline $\mathrm{NO}_{3}^{-}$ & 8.5 \\
\hline $\mathrm{SO}_{4}{ }^{-2}$ & 0.44 \\
\hline $\mathrm{H}_{2} \mathrm{O}$ & 83.4 \\
\hline
\end{tabular}




\subsection{WASTE SUMMARY AND CONDITIONS}

\subsubsection{Spatial Variability Description}

Two mechanisms are proposed to account for the spatial variability present in the waste in Tank 241-C-110. One is the relation between the flow of liquid waste in the tank to the settling and precipitation rates of solids. The other relates to the varying types of waste added to Tank 241-C-110 over its fill history.

It is possible that the spatial variability of the waste in Tank $241-\mathrm{C}-110$ is caused by the relation between the fill lines for incoming waste and the cascade overflow line to Tank 241-C-111. Fill lines are located approximately $150^{\circ}$ counterclockwise from the location of the cascade outlet (refer to Figure 2-2). As wastes were introduced into Tank 241-C-110, solids settled and precipitated from the liquid, which would finally overflow into Tank 241-C111. Based upon the rates at which the different waste solids formed and/or settled, constituent concentrations could be expected to vary between the inlet location and the waste outlet. A larger number of core samples, analyzed along very narrow horizons would be required to quantitatively determine this variability. However, some of the observed heterogeneity could possibly be attributed to the manner in which the tank was filled, and the restricted access and proximity of sampling locations to tank inlets and outlets.

Another potential mechanism to account for the variation between core samples is related to the fill history of Tank 241-C-110. The majority of solids in the tank resulted from $1 \mathrm{C}$ waste additions prior to 1950 (see Section 2.0). However, later additions of waste, including tributyl phosphate, organic wash waste, and coating waste, may have either left solids behind, or re-dissolved portions of the existing $1 \mathrm{C}$ solids. In either case, this would alter the constituent concentrations in the upper portions of the solids in Tank 241-C-110. The thickness of the effected region, or the amount of new deposits, could possibly vary over the surface of the waste (based on the first proposed mechanism). During core sampling, the uppermost segment from each core would contain this more recent or altered waste. Since core composites are made from all segment samples, this upper sample could bias the core sample analyte concentrations. This heterogeneity of the upper segments, however, is not supported by the Hot Cell Chemist's observations. If more rigorous analyses were performed of this portion of the waste, this mechanism could be possibly be verified or refuted.

\subsubsection{Comparisons Between Historical Data and Recent Analytical Data}

Comparisons have been made in this report between the most recent core sample results, the Historic Tank Content Estimate (ICF Kaiser Hanford, 1994), the TRAC model results (Jungfleisch, 1984), and past waste sampling activities (Sections 2.0 and 5.0 and Appendices $A$ and $B$ ). Based on these comparisons, several preliminary conclusions regarding the non-core sampling data can be made.

- The TRAC model estimates (Jungfleisch, 1984) seem to bear little correspondence to the estimates derived from the analytical data, with the exception of $\mathrm{Bi}, \mathrm{Cr}, \mathrm{Fe}$, and some of the radionuclides (Section 5.0 and Appendix B). For all other waste constituents modeled by TRAC, the TRAC estimate and the analytically derived Tank Characterization Report result differ 
by at least an order of magnitude. For example, Tank 241-C-110 has a tank inventory for Cs-137 of $17,300 \mathrm{Ci}$. Because of the manner in which the TRAC model accounts for cesium in solution, this radionuclide is not predicted to be part of the tank inventory. Similar model limitations exist for other waste constituents and properties (refer to Jungfleisch, 1984). Therefore, for the purposes of Tank 241-C-110, the TRAC model is generally inadequate as a predictive tool on an individual tank basis. It does seem likely, based on its initial inventory assumptions and the decay model used, that the TRAC model may be able to predict total Hanford Site radionuclide inventories, although not specific locations. As more Tank Characterization Reports are prepared for Hanford Site single-shell tanks, the ability of the TRAC model to predict waste inventories can be more fully assessed.

- Sample results from previous sampling and analysis activities show poor correlation to the current core sample analytical data (Section 5.0 and Appendices $A$ and B). Prior to the mid-1980's, when characterization became a central mission at the Hanford Site (Winters et al., 1990), the on-site laboratories analyzed samples primarily for process control purposes. Rapid turnaround times, critical analyte screening, and high laboratory throughput were the dominant analytical needs. Analytes considered at the time to be ancillary to the critical analyses were still frequently quantitated, but then reported for informational purposes only. For these reasons, sample data generated prior to the current core sampling should be viewed in context, and then used accordingly.

Estimates derived for the Historical Tank Content Estimate report (ICF Kaiser Hanford, 1994 ) show reasonably good agreement to the estimates obtained from the analytical data for the major metallic constituents of Tank 241-C-110 waste (Sections 2.0 and 5.0). However, the HTCE estimate misrepresents some major metals ( $\mathrm{Al}$ and $\mathrm{Zr}$ ) and all of the anions, neglects many of the trace constituents of the waste, and provides inconsistent agreement with the major radionuclides (good for ${ }^{90} \mathrm{Sr}$, poor for ${ }^{137} \mathrm{Cs}$ and uranium). This comparison is only valid for Tank 241-C-110; more tanks will require characterization before more definitive conclusions can be reached. It is possible that the HTCE estimate will prove to be an adequate predictive model for the major metallic waste constituents. As more comparisons between the HTCE results and Tank Characterization Report estimates are made, further conclusions about the utility and defensibility of the characterization information contained in the HTCE can be made.

\subsubsection{Leak Inventory Estimate}

As discussed in detail in Section 2.1, in 1984, Tank 241-C-110 was designated an Assumed Leaker with a leak estimate of 2,000 gallons of waste. An estimated inventory for this lost waste has been generated based on the 2,000 gallon leak volume, and is presented in Table 6-2. This inventory is useful to estimate possible contamination to the surrounding environment. 
Table 6-2. Inventory Assumed Leaked From Tank 241-C-110.

\begin{tabular}{|c|c|c|c|}
\hline Analyte & $\begin{array}{l}\text { Amount } \\
\text { Assumed } \\
\text { Leaked }\end{array}$ & Analyte & $\begin{array}{l}\text { Amount } \\
\text { Assumed } \\
\text { Leaked }\end{array}$ \\
\hline Metal & $(\mathrm{kg})$ & Metal & $(\mathrm{kg})$ \\
\hline Aluminum (Al) & 0.665 & Manganese (Mn) & 0.00217 \\
\hline Antimony (Sb) & 0.176 & Mercury (Hg) & 8.40E-04 \\
\hline Arsenic (As) & 0.0147 & Nickel (Ni) & 0.00878 \\
\hline Barium (Ba) & $<0.00229$ & Phosphorus (P) & 15.5 \\
\hline Beryllium (Be) & 0.00144 & Potassium (K) & 3.30 \\
\hline Bismuth (Bi) & 0.481 & Selenium (Se) & 0.245 \\
\hline Boron (B) & 0.119 & Silicon (Si) & 0.496 \\
\hline Cadmium (Cd) & 0.00335 & Silver $(\mathrm{Ag})$ & 0.00604 \\
\hline Calcium (Ca) & 0.130 & Sodium ( $\mathrm{Na})$ & 338 \\
\hline Cerium (Ce) & 0.0469 & Strontium (Sr) & 0.00611 \\
\hline Chromium (Cr) & 1.31 & Sulfur (S) & 22.3 \\
\hline Cobalt (Co) & 0.00491 & $\operatorname{Tin}(S n)$ & 0.0110 \\
\hline Copper (Cu) & 0.0133 & Titanium (Ti) & 0.00192 \\
\hline Iron (Fe) & 0.358 & Uranium (U) & 2.44 \\
\hline Lanthanum (La) & 0.00765 & Vanadium (V) & 0.0122 \\
\hline Lead $(P b)$ & 0.0407 & Zinc $(Z n)$ & 0.0120 \\
\hline Magnesium (Mg) & 0.0105 & Zirconium $(\mathrm{Zr})$ & 0.00435 \\
\hline Ion & $(\mathrm{kg})$ & Ion & $(\mathrm{kg})$ \\
\hline Ammonia $\left(\mathrm{NH}_{3}\right)$ & 0.654 & Nitrate $\left(\mathrm{NO}_{3}{ }^{-}\right)$ & 687 \\
\hline Chloride $(\mathrm{Cl})$ & 7.54 & Nitrite $\mathrm{NO}_{2}^{-}$) & 59.4 \\
\hline Cyanide $\left(\mathrm{CN}^{-}\right)$ & 0.0198 & Phosphate $\left(\mathrm{PO}_{4}{ }^{3 \cdot}\right)$ & 41.9 \\
\hline Fluoride $\left(F^{-}\right)$ & 3.91 & Sulfate $\left(\mathrm{SO}_{4}{ }^{2-}\right)$ & 84.0 \\
\hline Radionuclide & (Ci) & Radionuclide & (Ci) \\
\hline Americium-241 $\left({ }^{241} \mathrm{Am}\right)$ & $<3.91$ & Plutonium-239/240 (239/240 $\mathrm{Pu})$ & 0.0133 \\
\hline Carbon-14 $\left({ }^{14} \mathrm{C}\right)$ & 0.00151 & Selenium-79 $\left({ }^{79} \mathrm{Se}\right)$ & 4.67E-04 \\
\hline Cesium-137 $\left({ }^{137} \mathrm{Cs}\right)$ & 60.4 & Strontium-90 $\left({ }^{90} \mathrm{Sr}\right)$ & 0.210 \\
\hline Cobalt $-60\left({ }^{60} \mathrm{Co}\right)$ & $<0.0545$ & Technetium-99 $\left({ }^{99} \mathrm{Tc}\right)$ & 0.123 \\
\hline Europium-154 ( $\left.{ }^{154} \mathrm{Eu}\right)$ & $<0.145$ & Tritium $\left({ }^{3} \mathrm{H}\right)$ & 0.00544 \\
\hline Europium-155 $\left({ }^{155} \mathrm{Eu}\right)$ & $<0.164$ & Uranium-238 $\left({ }^{238} \mathrm{U}\right)$ & 1.96E-05 \\
\hline lodine-129 $\left({ }^{129}\right)$ & $<1.80 E-04$ & Total Alpha & 0.00531 \\
\hline Neptunium-237 $\left.1^{237} \mathrm{~Np}\right)$ & $<4.91 \mathrm{E}-04$ & Total Beta & 28.5 \\
\hline Plutonium-238 $\left({ }^{238} \mathrm{Pu}\right)$ & $<6.81$ E-05 & & \\
\hline
\end{tabular}




\subsubsection{Projected Tank Heat Load}

The low relative level of radionuclides in Tank $241-C-110$ is reflected in the low heat load (Table 6-3). Only five of the elements tested for were detected by the analytical methods used.

Table 6-3. Tank 241-C-110 Heat Load.

\begin{tabular}{|l|c|c|}
\hline \multicolumn{1}{|c|}{ Radionuclide } & Ci & Watts \\
\hline${ }^{241} \mathrm{Am}$ & $<287$ & $<0.220$ \\
\hline${ }^{137} \mathrm{Cs}$ & 20,000 & 95.8 \\
\hline${ }^{60} \mathrm{Co}$ & $<44.5$ & $<0.688$ \\
\hline${ }^{154} \mathrm{Eu}$ & $<123$ & $<1.12$ \\
\hline${ }^{155} \mathrm{Eu}$ & $<125$ & $<0.0919$ \\
\hline${ }^{129} \mathrm{I}$ & $<25.7$ & $<0.0119$ \\
\hline${ }^{237} \mathrm{~Np}$ & $<55.6$ & $<1.01$ \\
\hline${ }^{238} \mathrm{Pu}$ & $<51.1$ & $<0.167$ \\
\hline${ }^{239 / 240} \mathrm{Pu}$ & 82.4 & 2.52 \\
\hline${ }^{90} \mathrm{Sr}$ & 5.140 & 34.5 \\
\hline${ }^{99} \mathrm{Tc}$ & 33.7 & 0.0171 \\
\hline${ }^{238} \mathrm{U}$ & 0.508 & 0.0126 \\
\hline \multicolumn{2}{|c|}{ Total Watts } & $\sim 136$ \\
\hline
\end{tabular}

\subsection{PROGRAM ELEMENT SPECIFIC ANALYSES}

The sampling and analysis of Hanford Site waste tanks is driven by the need to satisfy the characterization requirements of the various Tank Waste Remediation System (TWRS) program elements. These characterization needs are implemented and documented through the Data Quality Objective process, and expressed in a series of program specific Data Quality Objective documents. The data needs are summarized in the TWRS Tank Waste Analysis Plan (Bell, 1994).

This Tank Characterization Report is the final step in the characterization of Tank 241C-110. According to the process and issue based data requirements, the inventory estimates and waste properties contained in this report can be applied to the data requirements of the various program elements. Contained in Table 6-4 is a summary of which program data needs are fulfilled through this characterization of the waste in Tank 241-C-110, based on a review of the stated sampling and analysis requirements. In the future, the applicability of Tank Characterization Report results to each TWRS program element will be documented in tank specific Tank Characterization Plans, prior to the tank sampling. 
Table 6-4. Applicability of Characterization Information to the Data Needs of the TWRS Program Elements.

\begin{tabular}{|l|c|}
\hline \multicolumn{1}{|c|}{ Data Quality Objective } & $\begin{array}{c}\text { Applicability to Characterization } \\
\text { of Tank 241-C-110 }\end{array}$ \\
\hline Tank Safety Screening & does not apply \\
\hline Ferrocyanide Safety Issues & does not apply \\
\hline Flammable Gas Tanks Crust Burn Issue & not addressed \\
\hline Generic Tank Vapor Issue Resolution & not completed \\
\hline Flammable Gas Tank & does not apply \\
\hline Waste Compatibility & does not apply \\
\hline Organic Fuel Rich Tank & does not apply \\
\hline Rotary Core Vapor Sampling & not completed \\
\hline Evaporator Operations & not completed \\
\hline Process Control & not completed \\
\hline Waste Tank Retrieval & not completed \\
\hline Waste Tank Pretreatment & not completed \\
\hline High-Level Immobilization & not completed \\
\hline Low-Level Immobilization & not completed \\
\hline Solid, Low-Level Waste Disposal & not completed \\
\hline RCRA Part B Permit Application & does not apply \\
\hline Tank C-106 High-Heat Safety Issue & does not apply \\
\hline Organic Layer Sampling of Tank C-103 & does not apply \\
\hline Tank C-103 Vapor and Gas Sampling & Sopning \\
\hline
\end{tabular}

${ }^{1}$ The sampling requirement for the Safety Screening Data Quality Objective (Babad, 1994) calls for both vertical waste samples and a vapor space sample. The sampling and analysis of Tank 241-C-110 supports full characterization of the waste in the tank; vapor space sampling or characterization was not conducted as part of this activity.

applies - The data needs expressed in this Data Quality Objectives document are fulfilled through this characterization report.

does not apply - The data needs expressed in this Data Quality Objectives document do not apply to the waste in Tank 241-C110.

not addressed - The data needs expressed in this Data Quality Objectives document were not addressed by this characterization report.

not complete - At the date of preparation of this report, this Data Quality Objectives document has not yet been completed. 


\subsection{STATISTICAL INTERPRETATION}

\subsection{MASS AND CHARGE BALANCE}

The principle objective in performing a mass and charge balance is to determine if the measurements are self-consistent. The mass and charge balance calculations also provide a method for estimating the weight percent of water. In calculating the balances, only analytes detected at a concentration of $1 \mathrm{ppm}$ or greater were considered.

Mass and charge balance results are reported in Table 7-1. This represents data for the solid portion of the tank contents only $(96 \%)$. The charge balance agrees, assuming that hydroxide ions account for part of the missing negative charge. The mass concentration, $\mu \mathrm{g} / \mathrm{g}$, resulting from the sum of the cations and anions, was subtracted from a million in order to obtain an estimated value for the weight percent of water. In other words, mass not accountable to the analyte concentrations is attributed to water. Inspection of the table indicates that the predicted weight percent of water is $62.7 \%$. This agrees fairly closely with the evaluated data result of $59.8 \%$.

Table 7-1. Tank 241-C-110 Mass and Charge Balance

(2 pages).

\begin{tabular}{|c|c|c|}
\hline \\
\hline & Mass $\mu \mathrm{g} / \mathrm{g}$ & Charge $\mu \mathrm{mol} / \mathrm{g}$ \\
\hline \multicolumn{3}{|c|}{ Cations } \\
\hline${ }^{1} \mathrm{ICP} \cdot \mathrm{a} \cdot \mathrm{Al}^{+3}$ & 14,500 & 1,611 \\
\hline${ }^{1} \mathrm{ICP}$. f.Sb ${ }^{+5}$ & 301 & 12.3 \\
\hline${ }^{2} \mathrm{ICP} \cdot$ a.As ${ }^{+5}$ & 4.1 & 0.27 \\
\hline ICP.a.Ba $\div 2$ & 7.68 & 0.11 \\
\hline ICP.a.Bi+3 & 16,800 & 241 \\
\hline ICP.f.Cd+2 & 5.36 & 0.10 \\
\hline ICP.f.Ca ${ }^{+2}$ & 1,150 & 57.4 \\
\hline ICP.a. $\mathrm{Ce}^{+3}$ & 210 & 4.50 \\
\hline ICP.f.Co+2 & 6.59 & 0.22 \\
\hline ICP.a.Cr ${ }^{+6}$ & 470 & 54.2 \\
\hline ICP.f.Cu+2 & 98.9 & 3.11 \\
\hline ICP.a.Fe ${ }^{+3}$ & 11,000 & 591 \\
\hline${ }^{3} \mathrm{ICP} \cdot \mathrm{W} \cdot \mathrm{La}^{+3}$ & 2.00 & 0.04 \\
\hline ICP.f.Pb +2 & 258 & 2.49 \\
\hline ICP.f.Mg ${ }^{+2}$ & 153 & 12.6 \\
\hline ICP.f. $\mathrm{Mn}^{+2}$ & 56.3 & 2.05 \\
\hline ICP.a. $\mathrm{Ni}^{+2}$ & 23.9 & 0.81 \\
\hline ICP.a.K ${ }^{+}$ & 557 & 14.2 \\
\hline
\end{tabular}


Table 7-1. Tank 241-C-110 Mass and Charge Balance (2 pages).

\begin{tabular}{|c|c|c|}
\hline & \\
\hline & Mass $\mu \mathrm{g} / \mathrm{g}$ & Charge $\mu \mathrm{mol} / \mathrm{g}$ \\
\hline \multicolumn{3}{|c|}{ Cations (continued) } \\
\hline ICP.w. $\mathrm{Ag}^{+}$ & 1.05 & 0.01 \\
\hline ICP.f. $\mathrm{Na}^{+}$ & 82,600 & 3,590 \\
\hline ICP.f.Sr+2 & 131 & 3.00 \\
\hline ICP.f.Sn+2 & 12.8 & 0.22 \\
\hline ICP.a. $\mathrm{Ti}^{+2}$ & 5.09 & 0.21 \\
\hline${ }^{4} L F . U^{+6}$ & 1,480 & 37.3 \\
\hline ICP.a. $V^{+5}$ & 6.17 & 0.60 \\
\hline 1CP.f. $2 n^{+2}$ & 224 & 6.85 \\
\hline ICP.f. $\mathrm{Zr}^{+4}$ & 172 & 7.56 \\
\hline \multicolumn{3}{|c|}{ Anions } \\
\hline Metasilicate ICP.f. $\mathrm{SiO}_{3}{ }^{-2}$ & 19,400 & 510 \\
\hline Selenite ICP.a. $\mathrm{SeO}_{3}{ }^{-2}$ & 113 & 1.77 \\
\hline Tetraborate ICP.W. $\mathrm{B}_{4} \mathrm{O}_{7}^{-2}$ & 89.8 & 1.16 \\
\hline${ }^{5}$ IC.W.F & 7,520 & 396 \\
\hline IC.w.Cl- & 1,100 & 31.0 \\
\hline IC.W. $\mathrm{NO}_{3}{ }^{-}$ & 110,000 & 1,770 \\
\hline IC.W.PO ${ }_{4}^{-3}$ & 62,200 & 1,904 \\
\hline IC.W. $\mathrm{SO}_{4}^{-2}$ & 15,200 & 317 \\
\hline Spec.W.NO ${ }_{2}^{-}$ & 7,260 & 158 \\
\hline \multicolumn{3}{|c|}{ Totals } \\
\hline Cations & 131,000 & 6,226 \\
\hline Anions & 223,000 & 5,150 \\
\hline Hydroxide & 18,800 & 1,103 \\
\hline Water (est.) & 627,000 & \\
\hline \multicolumn{3}{|c|}{ Tank Characterization Report Results } \\
\hline Water (TCR) & 598,000 & \\
\hline
\end{tabular}

1: ICP.a $=$ Inductively Coupled Plasma, acid digestion

2: ICP.f = Inductively Coupled Plasma, KOH/Nickel fusion dissolution

3: ICP.w = Inductively Coupled Plasma, water digestion

4: $\mathrm{LF}=$ Laser Fluorimetry

5: IC = Ion Chromatography, water digestion 


\subsection{STATISTICAL ANALYSIS}

\subsubsection{Introduction}

This section contains the results of a statistical analysis of data from the three core samples obtained from Tank 241-C-110 (Remund and Jensen, 1994). This statistical analysis was conducted on the solid segment material only $(180,000$ gallons, or $96 \%)$. No statistics were run on the drainable liquid portion of the tank $(7,000$ gallons, or $4 \%)$. Two topics are addressed here: the ability of the WHC 222-S Process and Analytical Laboratory to homogenize solid core segments, and estimates of the tank spatial and compositing variability.

Three core samples (cores 37, 38 and 39) were taken from Tank 241-C-110. The segment recoveries for each core are given in Table 3-5. Core 37 contained solid core sample material from segments 2,3 , and 4 . Core 38 contained solid core sample material from segments 1 and 4 . Core 39 contained solid core sample material from segments 2, 3, and 4. As mentioned in Chapter 3.3, the statistical results are biased due to the overall marginal core recoveries. The magnitude of this bias cannot be assessed with this data set.

Two core composite samples were made for each core (excluding core 38 ) from homogenized solid segment waste. Core 38 had only one core composite sample due to lack of solid segment material. Two samples were taken from each core composite. For the homogenization test, additional samples and duplicate samples were taken from two different locations.

In general, statistics were calculated for analytes with concentrations greater than 10 times their detection limits (DL). Analytical Evaluation and Reporting personnel, within the TWRS Information Management Systems, identified a list of critical analytes that have exception to this rule. Table 7-2 contains this critical list of analytes. Statistics were calculated for the analytes from this special list if the concentrations were greater than 3 times their DL. Analyte sample results with concentrations less than the DL were not used in any case. For a number of analytes, the concentrations of some samples were greater than a particular limit ( 3 or 10 times the $D L$ ) and the other samples were less than the limit. In these cases, the statistics were calculated using all of the data whether it was above or below the particular limit (3 or $10 \mathrm{DL}$ ).

Table 7-2. Special Analyte List.

\begin{tabular}{|ll|}
\hline Aluminum & Nitrate \\
Bismuth & Nitrite \\
Calcium & Phosphate \\
Chromium & Carbonate \\
Iron & Fluoride \\
Silicon & Chloride \\
Sodium & Total Organic Carbon \\
Zirconium & Cyanide \\
\hline
\end{tabular}




\subsubsection{Sample Homogenization Test}

A statistical test was conducted to determine the ability of the 222-S Laboratory to homogenize solid core segments. Segment 4 from core 38 and segment 3 from core 39 were homogenized and arbitrarily divided into two parts. One subsample was obtained from each part and two aliquots were taken from each subsample and prepared for chemical analysis. An ANOVA (Analysis of Variance) was then computed for 25 major analytes. For 21 out of 25 analytes, the variability between subsamples taken from different locations could not be distinguished from zero, indicating they were equivalent. Based on the results of this statistical test, it is generally concluded that the 222-S Laboratory can satisfactorily homogenize core segments (Remund and Jensen, 1994).

\subsubsection{Comparison of Variance Component Estimates}

The between core spatial variability, the compositing variability, and the analytical measurement variability can be separated from each other using the hierarchical structure of the core composite data. The spatial variance $\sigma^{2}(S)$ is a measure of the variability between cores. The compositing variance $\hat{\sigma}^{2}(C)$ measures the variability between composite samples within the same core. The analytical measurement variance includes, among other things, the segment homogenization error, the sample handling error, and the chemical analysis error. This variance is an estimate of the analytical error between the sample and duplicate samples, and a discussion of it is included in Section 7.3.

An ANOVA was computed for a hierarchical statistical model (Remund and Jensen, 1994). Appendix C contains a description of the model. An F-test, from the ANOVA, was used to test the hypothesis that $\sigma^{2}(S)$ is equal to zero (i.e., the tank is homogeneous). Another F-test, from the ANOVA, was used to test the hypothesis that there is not a significant difference between composite samples within the same core $\left(\hat{\sigma}^{2}(C)=0\right)$. The $p$ values (the attained level of significance) from the F-tests and the estimates of each components of variability are given in Table 7-3. If the p-value is smaller than 0.05 , then $\sigma^{2}(S)$ or $\sigma^{2}(C)$ are significantly different from zero.

Only those analytes with concentrations greater than $1 \mathrm{ppm}$ or $1 \mathrm{uCi} / \mathrm{g}$ were included. The analytical method that gave the highest concentration for a given analyte was the one listed in Table 7-4. Column 1 of Table 7-4 gives the analysis method used, digestion, and analyte.

Table 7-3. Variance Components Test Results. (2 pages)

\begin{tabular}{|l|c|c|c|c|c|}
\hline \multicolumn{1}{|c|}{ Analyte } & $\sigma^{2}(\mathrm{~S})$ & $\begin{array}{c}\text { Spatial } \\
\text { Variability } \\
\sigma^{2}(\mathrm{~S}) \\
\mathrm{p} \text {-value }\end{array}$ & $\sigma_{2}(\mathrm{C})$ & $\begin{array}{c}\text { Compositing } \\
\text { Variability } \\
\sigma^{2}(\mathrm{C}) \text { p-value }\end{array}$ & $\sigma_{2}(\mathrm{~A})$ \\
\hline${ }^{1} \mathrm{ICP} . \mathrm{a} . \mathrm{Al}$ & $4.45 \mathrm{E}+05$ & 0.003 & $6.94 \mathrm{E}-29$ & 0.811 & $1.15 \mathrm{E}+05$ \\
\hline ICP.a.Ba & $3.02 \mathrm{E}+00$ & 0.000 & $1.40 \mathrm{E}-30$ & 0.609 & $5.91 \mathrm{E}-02$ \\
\hline${ }^{2} \mathrm{ICP} . \mathrm{f} . \mathrm{Ca}{ }^{*} \#$ & $6.38 \mathrm{E}-31$ & 0.843 & $1.35 \mathrm{E}-14$ & 0.329 & $1.71 \mathrm{E}+06$ \\
\hline ICP.a.Cr & $1.16 \mathrm{E}+03$ & 0.000 & $1.48 \mathrm{E}-36$ & 0.983 & $1.25 \mathrm{E}+02$ \\
\hline ICP.f.Cu & $4.12 \mathrm{E}+03$ & 0.035 & $1.38 \mathrm{E}-12$ & 0.941 & $2.28 \mathrm{E}+03$ \\
\hline
\end{tabular}


Table 7-3. Variance Components Test Results. (2 pages)

\begin{tabular}{|c|c|c|c|c|c|}
\hline Analyte & $\sigma^{2}(S)$ & $\begin{array}{c}\text { Spatial } \\
\text { Variability } \\
\sigma^{2}(S) \\
\text { p-value }\end{array}$ & $\sigma_{2}(C)$ & $\begin{array}{l}\text { Compositing } \\
\text { Variability } \\
\sigma^{2}(C) \text { p-value }\end{array}$ & $\sigma_{2}(A)$ \\
\hline ICP.a.Fe & $1.84 E+06$ & 0.000 & $6.53 E-25$ & 0.622 & $1.05 E+05$ \\
\hline ICP.f.Pb \# \# & $2.72 E+04$ & 0.000 & $4.45 E+01$ & 0.250 & $1.05 E+02$ \\
\hline ICP.f.Mg & $6.65 \mathrm{E}-26$ & 0.831 & $3.54 \mathrm{E}-19$ & 0.447 & $1.28 E+03$ \\
\hline ICP.f.Mn & $3.84 E-13$ & 0.350 & $1.51 E+01$ & 0.451 & $4.23 E+02$ \\
\hline ICP.a.Ni\# & $2.29 E-23$ & 0.977 & $1.36 \mathrm{E}-13$ & 0.328 & $2.21 E+02$ \\
\hline ICP.a.K & $2.11 E+03$ & 0.001 & $4.38 E+02$ & 0.011 & $7.33 E+01$ \\
\hline ICP.a.Se \# & $3.60 E+03$ & 0.000 & $5.04 E-25$ & 0.710 & 2.37E + 01 \\
\hline ICP.f. Na & $2.13 E+07$ & 0.008 & $4.02 E+06$ & 0.172 & $4.95 E+06$ \\
\hline ICP.a.V\# & $4.68 E+00$ & 0.000 & $6.72 E-36$ & 0.621 & 2.99E-01 \\
\hline ICP.f.Zn & $1.36 E+06$ & 0.160 & 9.91E-06 & 0.422 & $3.10 E+03$ \\
\hline ICP.a.Bi & $4.14 E+06$ & 0.000 & $2.09 E-36$ & 0.849 & $6.65 E+04$ \\
\hline${ }^{3}$ ICP.W.B & $8.48 E-20$ & 0.675 & $3.54 E+01$ & 0.000 & 4.09E-01 \\
\hline ICP.a.Ce & $5.19 E+02$ & 0.000 & $5.35 E-11$ & 0.451 & $5.12 E+01$ \\
\hline ICP.f.P & $2.33 E+06$ & 0.026 & $1.36 E+06$ & 0.098 & $9.58 E+05$ \\
\hline ICP.f.Si & $5.31 E+05$ & 0.000 & $1.66 \mathrm{E}-09$ & 0.458 & $1.80 E+04$ \\
\hline ICP.a.S & $3.45 E+05$ & 0.000 & $8.89 E+02$ & 0.318 & $3.92 E+03$ \\
\hline ICP.a.Ti\# & $2.15 \mathrm{E}-01$ & 0.051 & $1.00 \mathrm{E}-01$ & 0.202 & $1.70 \mathrm{E}-01$ \\
\hline ICP.f.Zr & $6.67 E+02$ & 0.087 & $9.88 E+01$ & 0.003 & $8.89 E+00$ \\
\hline${ }^{4}$ IC.W.F & $2.26 E+06$ & 0.208 & $1.29 E+06$ & 0.002 & $1.11 E+05$ \\
\hline IC.w.Cl & $1.08 E+05$ & 0.369 & $1.92 E+05$ & 0.000 & $9.74 \mathrm{E}+02$ \\
\hline IC.W.NO3 & $1.65 E+08$ & 0.000 & $1.70 \mathrm{E}-32$ & 0.682 & $1.51 E+07$ \\
\hline IC.w.PO4 & $1.44 E+08$ & 0.001 & $5.86 E+06$ & 0.306 & $2.39 E+07$ \\
\hline IC.w.SO4 & $2.52 E+07$ & 0.000 & $1.54 E+06$ & 0.170 & $1.99 E+06$ \\
\hline Spec.w.NO2 & $1.97 E+07$ & 0.000 & $5.52 E+04$ & 0.142 & $5.65 E+04$ \\
\hline $\mathrm{pH}$ & 8.32E-03 & 0.384 & $3.45 \mathrm{E}-02$ & 0.004 & 3.38E-03 \\
\hline${ }^{5} \mathrm{GEA} .{ }^{137} \mathrm{Cs}$ & $1.90 E+01$ & 0.000 & $6.65 \mathrm{E}-02$ & 0.342 & 3.97E-01 \\
\hline${ }^{90} \mathrm{Sr}$ & $3.33 E+00$ & 0.000 & $1.65 \mathrm{E}-02$ & 0.380 & $1.87 \mathrm{E}-01$ \\
\hline
\end{tabular}

1: ICP.a = Inductively Coupled Plasma, acid digestion

2: $\mathrm{ICP} . \mathrm{f}=$ Inductively Coupled Plasma, $\mathrm{KOH} /$ Nickel fusion dissolution

3: ICP.w = Inductively Coupled Plasma, water digestion

4: IC = Ion Chromatography, water digestion

5: GEA = Gamma Energy Analysis

- Analytes with a portion of the data below 3 times the DL.

\#: Analytes with all or a portion of the data below 10 times the DL. 
WHC-SD-WM-ER-367 REV O

Table 7-4. Measurement Error Estimates. (2 pages)

\begin{tabular}{|c|c|c|c|c|}
\hline \multirow{2}{*}{ Analyte } & \multicolumn{2}{|c|}{$\begin{array}{c}\text { Analytical Error Estimate - } \\
1 \mathrm{RSD}(\%) \\
\end{array}$} & \multicolumn{2}{|c|}{$\begin{array}{c}\text { Systematic Error Estimate - } \\
1 \text { RSD }(\%)\end{array}$} \\
\hline & $\begin{array}{l}\text { From Sample } \\
\text { Results }\end{array}$ & $\begin{array}{c}\text { From Standard } \\
\text { Results }\end{array}$ & $\begin{array}{l}\text { From Standard } \\
\text { Results }\end{array}$ & $\begin{array}{c}\text { From Spike } \\
\text { Analyses }\end{array}$ \\
\hline${ }^{i}$ ICP.a.Al & 3.7 & 2.7 & 17 & 1176 \\
\hline ICP.a.Ba & 4.9 & 2.7 & 4.7 & 7.9 \\
\hline${ }^{2}$ ICP.f.Ca*\# & 53 & 3.2 & 2.4 & 1.4 \\
\hline ICP.a.Cr & 4.0 & 2.9 & 2.7 & 58 \\
\hline ICP.f.Cu & 95 & 2.0 & 2.5 & 0.7 \\
\hline ICP.a.Fe & 4.5 & 2.5 & 39 & 1289 \\
\hline ICP.f.Pb* \# & 5.5 & 3.5 & 3.5 & 1.9 \\
\hline ICP.f.Mg & 37 & 3.0 & 3.4 & 2.8 \\
\hline ICP.f.Mn & 55 & 2.4 & 5.2 & 4.3 \\
\hline ICP.a.Ni\# & 93 & 2.6 & 1.4 & 9.6 \\
\hline ICP.a.K & 2.1 & 3.8 & 21 & 26 \\
\hline ICP.a.Se \# \# & 16 & 4.5 & 16 & 7.3 \\
\hline ICP.f.Na & 3.7 & 2.9 & 5.2 & 12 \\
\hline ICP.a.V\# & 13 & 2.5 & 3.6 & 7.1 \\
\hline ICP.f.Zn & 36 & 2.5 & 1.1 & 1.2 \\
\hline ICP.a.Bi & 2.5 & 2.6 & 24 & 2014 \\
\hline${ }^{3}$ ICP.W.B & 3.4 & 4.4 & 6.0 & 5.4 \\
\hline ICP.a.Ce & 4.8 & 2.8 & 17.6 & 28 \\
\hline ICP.f.P & 6.8 & 5.0 & 2.9 & 7.9 \\
\hline ICP.f.Si & 2.7 & 2.6 & 4.0 & 4.6 \\
\hline ICP.a.S & 2.2 & 3.9 & 246 & 286 \\
\hline ICP.a.Ti\# & 12 & 3.6 & 3.4 & 8.4 \\
\hline ICP.f.Zr & 2.6 & 4.6 & 3.2 & 2.8 \\
\hline${ }^{4}$ IC.W.F & 6.3 & 4.7 & 2.0 & 13 \\
\hline IC.w.Cl & 4.0 & 3.3 & 4.2 & 6.2 \\
\hline IC.w.NO3 & 5.5 & 4.3 & 2.9 & 7.3 \\
\hline IC.W.PO4 & 24 & 3.9 & 2.0 & 8.0 \\
\hline IC.w.SO4 & 13 & 2.7 & 1.3 & 12 \\
\hline
\end{tabular}


Table 7-4. Measurement Error Estimates. (2 pages)

\begin{tabular}{|l|c|c|c|c|}
\hline \multirow{2}{*}{\begin{tabular}{l} 
Analyte \\
\hdashline
\end{tabular}} & $\begin{array}{c}\text { Analytical Error Estimate - } \\
\text { I RSD (\%) }\end{array}$ & \multicolumn{2}{|c|}{$\begin{array}{r}\text { Systematic Error Estimate - } \\
\text { 1 RSD (\%) }\end{array}$} \\
\cline { 2 - 5 } & $\begin{array}{c}\text { Fom Sample } \\
\text { Results }\end{array}$ & $\begin{array}{c}\text { From Standard } \\
\text { Results }\end{array}$ & $\begin{array}{c}\text { From Standard } \\
\text { Results }\end{array}$ & $\begin{array}{c}\text { From Spike } \\
\text { Analyses }\end{array}$ \\
\hline Spec.w.NO2 & 3.3 & 3.1 & 2.7 & 4.7 \\
\hline pH & 0.7 & 0.2 & 0.6 & NA \\
\hline${ }^{5} \mathrm{GEA} .{ }^{137} \mathrm{Cs}$ & 4.6 & 2.2 & 0.2 & 32 \\
\hline${ }^{90} \mathrm{Sr}$ & 12 & 5.4 & 7.1 & 4.2 \\
\hline
\end{tabular}

1: ICP.a = Inductively Coupled Plasma, acid digestion

2: ICP.f = Inductively Coupled Plasma, KOH/Nickel fusion dissolution

3: ICP. $w=$ Inductively Coupled Plasma, water digestion

4: IC = lon Chromatography, water digestion

5: GEA = Gamma Energy Analysis

* Analytes with a portion of the data below 3 times the DL.

\#: Analytes with all or a portion of the data below 10 times the DL.

\&: Calculated from the Laboratory Measurement Control System standards analyzed in conjunction with the samples.

In 21 out of 32 cases tested, the p-values from the tests on $\sigma^{2}(S)$ are less than 0.05 . For these 21 cases, the spatial variability is significantly greater than zero, a strong indication that the solid portion (96\%) of the tank is heterogeneous. This is in addition to the heterogeneity created by the drainable liquid portion of the tank $(4 \%)$.

In 26 out of 32 cases tested, the p-values from the tests on $\sigma^{2}(C)$ are greater than 0.05 . For these 26 cases, there is no significant difference between the composite samples from core 37. Based on the core composite data from Tank 241-C-110, the 222-S Laboratories can adequately create reproducible core composites.

\subsection{ANALYTICAL ERROR ESTIMATION}

Analytical error is composed of two parts, random and systematic. Table 7-4 gives both the analytical and systematic error estimates, organized by analyte.

\subsubsection{Random Analytical Error}

The random analytical error is determined from the analytical results of the duplicate samples. It can also be estimated from the analysis of standards. The estimates for all analytes are taken from actual data only (no estimated data).

Although the value for $V$ appeared low, it had one duplicate sample with an RPD or RSD over the criterion of 3 times the random analytical error from sample results. Despite high RSD values for $\mathrm{Ca}, \mathrm{Cu}, \mathrm{Mg}, \mathrm{Mn}, \mathrm{Ni}$, and $\mathrm{PO}_{4}^{-3}$, none of the sample duplicates for these analytes had any RPD's over the criterion. The high values for $\mathrm{Ca}$ and $\mathrm{Ni}$ can be explained in part by some of their sample results being close to the detection limit, and the presence of a few outliers. In general, standard deviations for all analytes were not unusually high. 


\subsubsection{Systematic Analytical Error}

The systematic error estimate was determined from the analysis of standards or spike recoveries. For most of the analytes the differences between the two estimates are not large (Table 7-4). For a number of the metals, $\mathrm{S}$, and ${ }^{37} \mathrm{Cs}$, the estimates for spikes were outside the $100 \pm 25 \%$ limits. The high Fe value was partially due to contamination of the blank and sample during preparation. Spike failures for major elements in general are frequently caused by a high element concentration in the sample. When the added spike concentration is insignificant compared to the concentration present in the sample, a failure usually occurs. 


\subsection{CONCLUSION AND RECOMMENDATIONS}

\subsection{SAFETY ISSUES}

Characterization of Tank 241-C-110 supports the classification of the tank as nonWatch List. Given the current tank inventory of fissionable radionuclides and organic or exothermic waste constituents, no credible potential exists for further loss of tank integrity or release of radioactivity due to in-tank processes. Tank 241-C-110 is an Assumed Leaker; however, the liquid volume and waste level in the tank have remained relatively constant since 1984 (Anderson, 1990; Hanlon, 1994). Tank 241-C-110 is within established operating safety requirements, as defined by applicable Data Quality Objectives.

Thermocouple data support the conclusion that there are no significant heat-generating processes within the tank waste; there is no credible risk of self-boiling or excessive heating of the current tank contents. Given the generally stable waste properties, and taking into account the still questionable tank integrity, continued storage of the waste in Tank 241-C110 poses no unreasonable risk to personnel, the public, or the environment.

\subsection{FURTHER CHARACTERIZATION NEEDS}

Characterization of the solid and liquid contents of Tank 241-C-110 has been performed in this report. While the current characterization is quite extensive, further sampling and analysis of the contents of Tank $241-\mathrm{C}-110$ is suggested for the following waste properties:

- If determination of vertical layering in the wastes and variations in analyte concentrations with waste depth are important for safety, retrieval, or other program elements, then additional analyses of segment and sub-segment samples are required.

- An analysis of the tank vapor space would allow final resolution of any safety concerns regarding the presence of flammable or noxious gases.

\subsection{CONCLUSIONS}

This Tank Characterization Report contains comparisons made between core sampling analytical data and on-going efforts to historically predict the waste contents of Tank 241-C110 (Section 6.2.2). A more detailed and systematic review of these data sources will be possible as additional Hanford Site waste tanks are characterized. Hypotheses to be tested during this comparison include whether it will be possible to perform a preliminary Safety Screening of a waste tank prior to core sampling, and whether process design decisions can be made based on extremes in expected tank contents. One function of this report is to initiate this effort. 


\subsection{REFERENCES}

Anderson, J. D., 1990. A History of the 200 Area Tank Farms, WHC-MR-0132, Westinghouse Hanford Company, Richland, WA.

Babad, H., 1994. Tank Safety Screening Data Quality Objective, WHC-SD-WM-004, Westinghouse Hanford Company, Richland, WA.

Bell, K.E., 1994. Tank Waste Remediation System Tank Waste Analysis Plan, WHC-SD-WMPLN-077, Rev. 1, Westinghouse Hanford Company, Richland, WA.

Conway, J.T., 1993. DNFSB Recommendation 93-5 to the Secretary of Energy, (letter 9400070 to H.R. O'Leary, DOE, July 19) Defense Nuclear Facilities Safety Board, Washington, D.C.

De Lorenzo, D.S., J.H. Rutherford, D.J. Smith, D.B. Hiller, and K.W. Johnson, 1994. Tank Characterization Reference Guide, WHC-SD-WM-TI-648, Los Alamos Technical Associates, Inc., Richland, WA.

Ecology, 1991. Dangerous Waste Regulations, 170-303, Washington Department of Ecology, Olympia, WA.

EPA, 1990. "Identification and Listing of Hazardous Wastes," 40 CFR 261, U.S. Environmental Protection Agency, Washington D.C.

Edrington, R. S. BY and C Tank Farm Supernate Sample Analysis (Revision of 16220-PCL90117) - Sample R8087, 28110-PCL91-048, Westinghouse Hanford Company Internal Memo to R. K. Tranbarger, dated June 3, 1991.

Ecology, EPA, \& DOE, 1993. Hanford Federal Facility Agreement and Consent Order, Washington State Department of Ecology, United States Department of Energy, Richland, WA.

Fulton, J.C., 1992. Riser Configuration Survey for SSTS, WHC-SD-RE-TI-053, Rev. 8, Westinghouse Hanford Company, Richland, WA.

Hanford Engineer Works, 1994. Storage Tanks T-U-B \& C Arrangement, Drawing No. H-W72743, Hanford Engineer Works, Richland, WA.

Hanlon, B.M., 1993. Tank Farm Surveillance and Waste Status Summary Report for November 1993, WHC-EP-0182-68, Westinghouse Hanford Company, Richland, WA.

Husa, E.I., R.E. Raymond, R.K. Welty, S.M. Griffith, B.M. Hanlon, R.R. Rios, and N.J. Vermueulen, 1993. Hanford Site Waste Storage Tank Information Notebook, WHC-EP0625, Westinghouse Hanford Company, Richland, WA.

ICF Kaiser Hanford, 1994. Historical Tank Content Estimate for the Northeast Quadrant of the 200 East Areas, WHC-EP-0759, Rev. O, Westinghouse Hanford Company, Richland, WA. 
Jungfleisch, F. M., 1984. TRAC: Preliminary Estimation of the Waste Inventories in Hanford Tanks Through 1980, SD-WM-TI-057, Rockwell Hanford Operations, Richland, WA.

McKinley, S.G., L.R. Greenwood, E.W. Hoppe, and J.M. Tingey. 222-S Analytical Laboratory Single-Shell Tank Waste Characterization, Tank C-110, WHC-SD-WM-DP-027, Addendum 4, Rev. O., Westinghouse Hanford Company, Richland, WA.

Remund, K.M., and L. Jensen, 1994. Statistical Characterization Report for Single-Shell Tank 241-C-110, WHC-SD-WM-TI-585, Rev. 0, Westinghouse Hanford Company, Richland, WA.

Rios, R.R., 1994. Computer Automated Surveillance System, Westinghouse Hanford Company, Richland, WA.

Schneider, K.J., 1951. Flow Sheets and Flow Diagrams of Precipitation Separations Process, HW-23043. Battelle Pacific Northwest Laboratory, Richland, WA.

Starr, J. L. Analysis of Tank 110-C Sludge - Sample \#9501, Rockwell International Internal Letter to J. W. Bailey, dated November 10, 1977.

Vitro Engineering Corporation, 1980. Piping Waste Tank /solation Tk 241-C-110, Drawing No. H-2-73061, Vitro Engineering Corporation, Richland, WA.

WHC, 1992. 222-S Analytical Laboratory Single-Shell Tank Waste Characterization, Tank C110, WHC-SD-WM-DP-027, Rev. O, Westinghouse Hanford Company, Richland, WA.

Wheeler, R. E., Analysis of Tank Farm Samples - Sample: T-5491, Tank 110-C, Atlantic Richfield Hanford Company letter to R. L. Walser, dated September 19, 1975,

Winters, W. I., L. Jensen, L. M. Sasaki, R. L. Weiss, J. F. Keller, A. J. Schmidt, and M. G. Woodruff, 1990. Waste Characterization Plan for Hanford Site Single-Shell Tanks, WHC-EP-0210, Westinghouse Hanford Company, Richland, WA. 
WHC-SD-WM-ER-367 REV O

APPENDIX A

ANALYTICAL DATA 


\section{A.1 INTRODUCTION}

A.1.1 Appendix A presents the chemical and radiological characteristics of Tank 241-C-110 in a tabular form, in terms of the specific concentrations of anions, metals, physical properties, and radionuclides.

The data table for each analyte lists laboratory sample identification, an analytical data result for each sample, weighted (statistical) mean, standard deviation, an evaluated data result, and a projected tank inventory for the particular analyte. The projected tank inventory column is not applicable for the specific gravity, ph, or percent water data. The data are listed in standard notation for values $>.001$ and $<100,000$. Values outside these limits are listed in scientific notation.

\section{A.2 TABLE DESCRIPTION}

\section{A.2.1 Abbreviations}

Standard abbreviations are used to describe analytical methods.

\begin{tabular}{|c|c|}
\hline \multirow[t]{5}{*}{ Metals: } & $\begin{array}{l}\text { ICP - Inductively Coupled Plasma (generic for all metals unless } \\
\text { otherwise known) }\end{array}$ \\
\hline & GFAA - Graphite Furnace Atomic Absorption \\
\hline & GHAA - Gaseous Hydride Atomic Absorption \\
\hline & CVAA - Cold Vapor Atomic Absorption \\
\hline & FAA - Flame Atomic Absorption \\
\hline Anions: & IC - Ion Chromatography \\
\hline \multirow[t]{5}{*}{ Radionuclides: } & GEA - Gamma Energy Analysis \\
\hline & AEA - Alpha Energy Analysis \\
\hline & APC - Alpha Proportional Counting \\
\hline & BPC - Beta Proportional Counting \\
\hline & LSC - Liquid Scintillation Counting \\
\hline \multirow[t]{4}{*}{ Physical Properties: } & PT - Physical Testing \\
\hline & DM - Direct Measurement \\
\hline & DSC - Differential Scanning Calorimetry \\
\hline & TGA - Thermogravimetric Analysis \\
\hline
\end{tabular}




\section{A.3 Column Headings}

A.3.1 The "Analyte" column contains, in addition to the name of the analyte or physical characteristic, information about the method of measurement, and in the case of the metals, information about the method of digestion. The method of digestion is listed for the metals, because unlike the other analytes, different digestion procedures are typically used for the same metal.

Possible digestion methods are: $d$ - direct; a - acid digestion; $w$ - water leach; and $f$ potassium hydroxide fusion.

The analyte and method are presented as follows: "method.analyte," or, (in the case of a metal) "method.digestion.analyte." For example, the specific concentration of ${ }^{90} \mathrm{Sr}$ was measured with a beta proportional counter and is listed "BPC. ${ }^{90} \mathrm{Sr} . "$ A specific concentration of $\mathrm{Pb}$ was determined by the inductively coupled plasma method which was preceded by acid digestion, and is listed as "ICP.a.Pb."

A.3.2 The "Laboratory Sample Identification" column lists the samples for which the analyte was measured; this identification number is different from the number assigned to the samples at the tank farm. Sampling rationale, locations, and descriptions of sampling events are contained in Section 3.0.

A.3.3 "Analytical Data Result" is the specific concentration of the analyte determined at different sampling points. No quality control data such as matrix spikes, serial dilutions, or duplicate analyses are listed. This information may be obtained from the 241-C-110 data package (WHC-SD-WM-DP-027). Data which was qualified as estimated (denoted by "J" or "UJ" in the data package) will be enclosed in parentheses, i.e., (395) $\mu \mathrm{g} / \mathrm{ml}$. Unusable data (denoted by " $R$ " in the data package) will be entered with a strikeout, i.e., $395 \mu \mathrm{g} / \mathrm{ml}$. Unqualified data will be entered in standard form.

A.3.4 The "Range of Values" column lists the highest and the lowest values for a particular analyte. If a measurement method has a constant method detection limit (MDL), and all results are less than the MDL, no range is given. However, if the MDL changes, (i.e., due to radiation background variations in radiochemistry) a range of detection limit values is given.

A.3.5 "Weighted Mean/Standard Error" is computed statistically for those solid sample results greater than the detection limit, with the exception of the results obtained from segment analysis.

A.3.6 Column 6 "Evaluated Data Result" is the average of all the listed sample results.

A.3.7 Column 7, "Projected Inventory," is the product of the concentration of the analyte (See Section 5 for description of selection process) and the volume of the waste in the tank. (187,000 gallons or $708,000 \mathrm{~L})$. 


\section{LIST OF TABLES FOR APPENDIX A}

Table A-1. Tank 241-C-110 Analytical Data:

Aluminum .......................... A

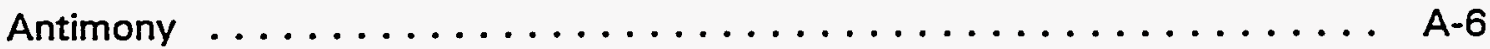

Arsenic ........................... A

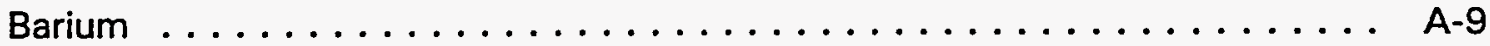

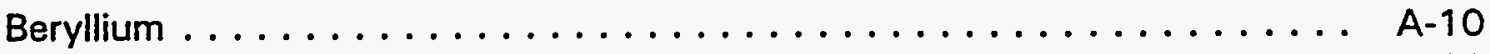

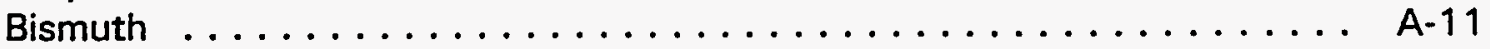

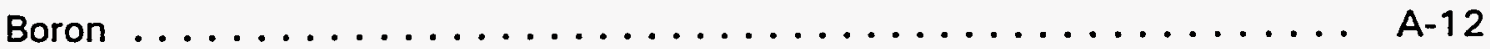

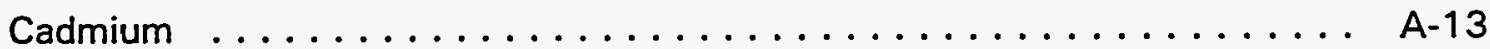

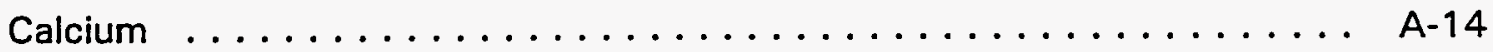

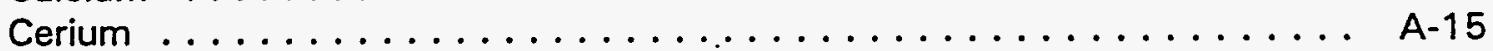

Chromium ......................... A-16

Cobalt ............................ A $\ldots \ldots \ldots$

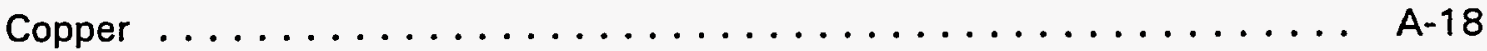

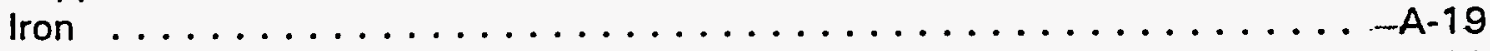

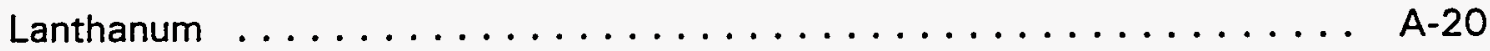

Lead .............................. A-21

Magnesium ............................ A-22

Manganese ........................... A-23

Mercury ............................ A-24

Nickel ................................ A-25

Phosphorus .......................... A-26

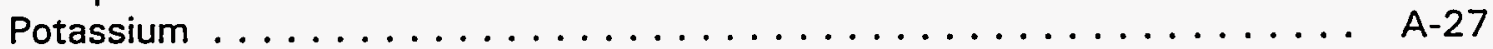

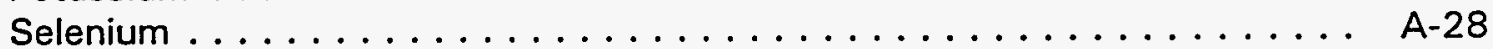

Silicon .............................. A-29

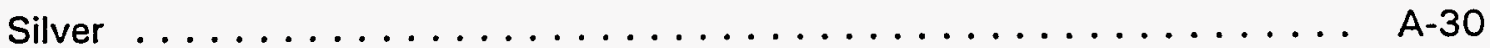

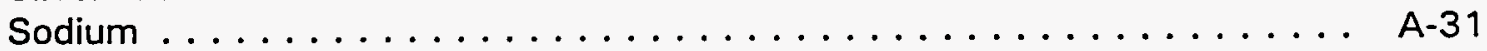

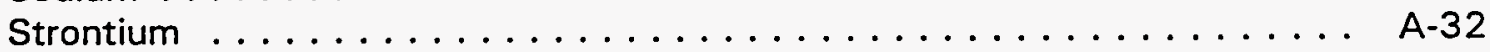

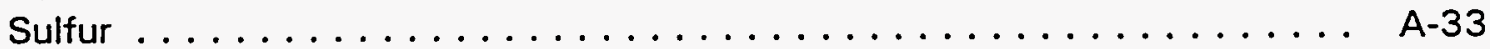

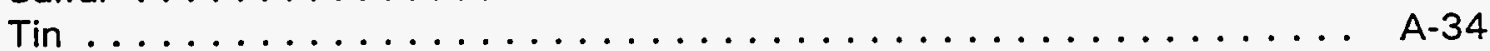

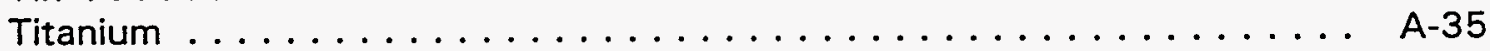

Uranium .......................... A-36

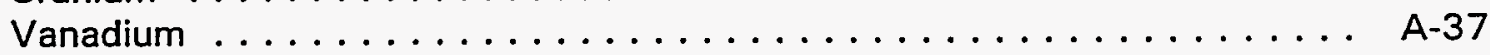

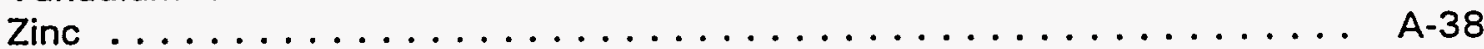

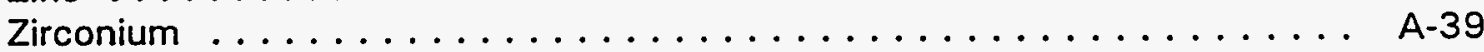

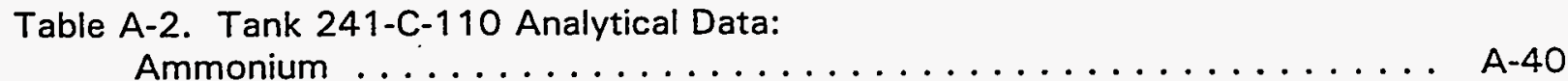

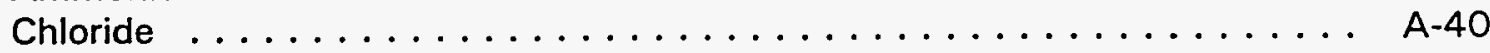

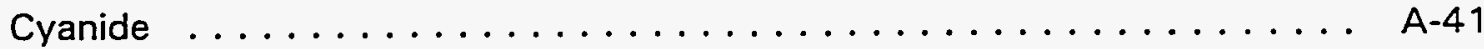

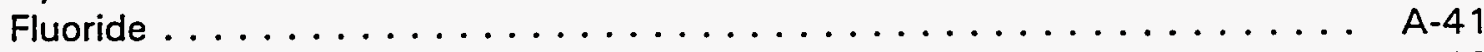

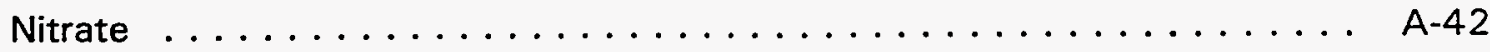

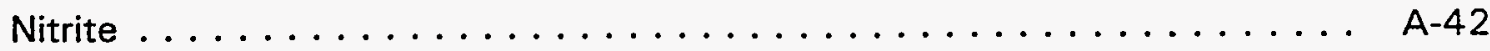

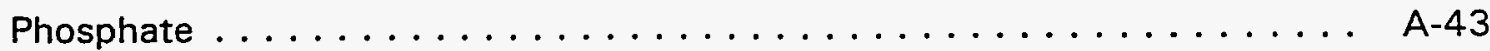

Sulfate ........................... A-43 


\section{LIST OF TABLES FOR APPENDIX A (continued)}

Table A-3. Tank 241-C-110 Analytical Data:

Americium-241 ............................ A A-44

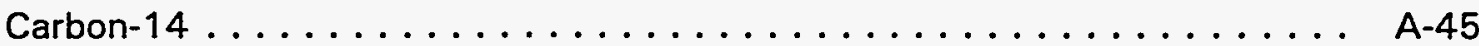

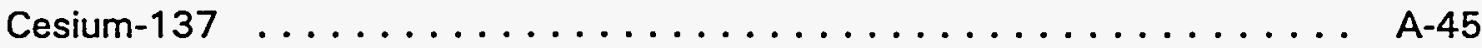

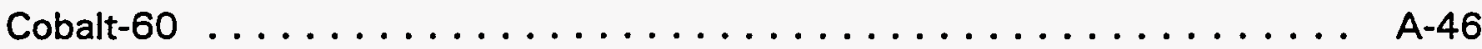

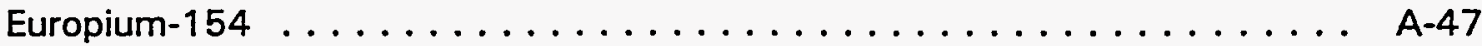

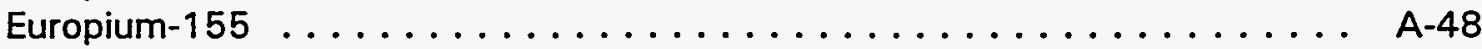

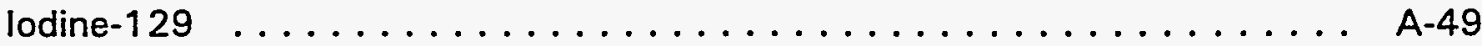

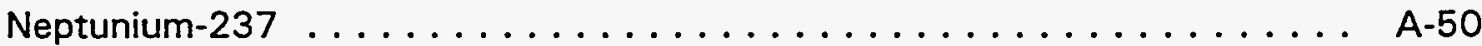

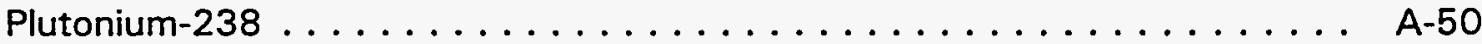

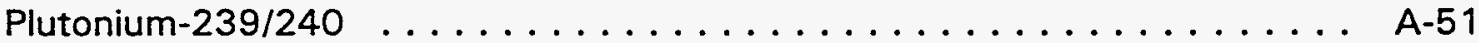

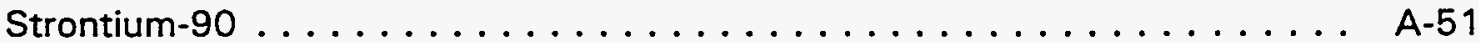

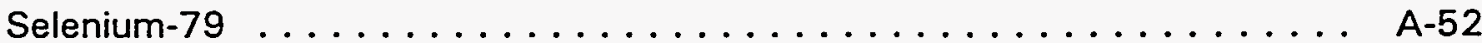

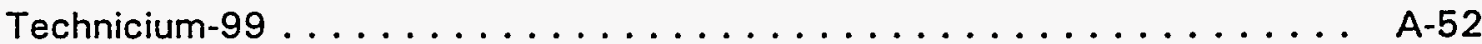

Tritium ......................... A-53

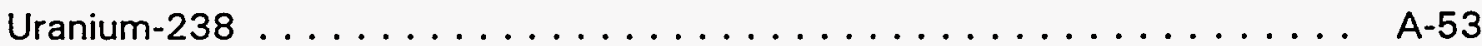

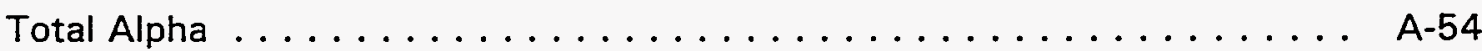

Total Beta . . . . . . . . . . . . . . . . . . . . . . A A-55

Table A-4. Tank 241-C-110 Analytical Data:

Percent Water . . . . . . . . . . . . . . . . . . . . . . . A A-56

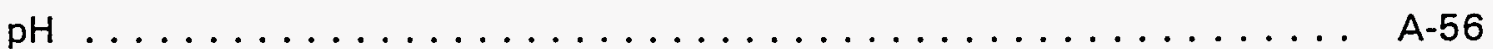

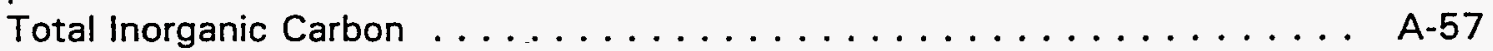

Total Organic Carbon . . . . . . . . . . . . . . . A A-57

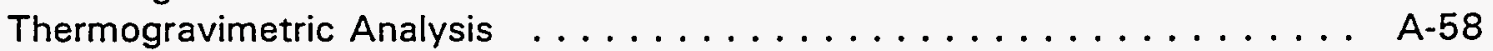

Specific Gravity . . . . . . . . . . . . . . . . . . . A 4 .58

Table A-5. Tank 241-C-110 Analytical Data:

Volatile Organics ........................ A-59

Decane ............................... A-60

Undecane ............................ A-60

Dodecane ............................. A-61

Tridecane ........................... A-61

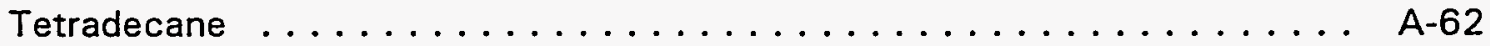

Table A-6. Tank 241-C-110 Analytical Data:

Semivolatile Organic ......................... A-63

Decane ............................... A-64

Undecane ............................. A

Dodecane ............................. A $\ldots \ldots 4$

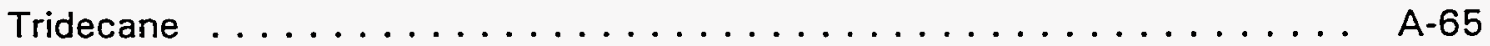

Tetradecane .......................... A-65

Pentadecane ........................... A-66

Phosphoric acid tributyl ester . . . . . . . . . . . . . . . . . A-66 
Table A-1. Tank 241-C-110 Analytical Data: Aluminum

\begin{tabular}{|c|c|c|c|c|c|c|}
\hline Analyte & $\begin{array}{c}\text { Laboratory } \\
\text { Sample } \\
\text { Identification }\end{array}$ & $\begin{array}{l}\text { Analytical } \\
\text { Data } \\
\text { Result }\end{array}$ & $\begin{array}{c}\text { Range } \\
\text { of } \\
\text { Values }\end{array}$ & $\begin{array}{c}\text { Weighted } \\
\text { Mean/ } \\
\text { Standard } \\
\text { Error }\end{array}$ & $\begin{array}{c}\text { Evaluated } \\
\text { Data } \\
\text { Result }\end{array}$ & $\begin{array}{l}\text { Projected } \\
\text { Inventory }\end{array}$ \\
\hline Metal (Liquid) & & $\mu \mathrm{g} / \mathrm{mL}$ & $\mu \mathrm{g} / \mathrm{mL}$ & $\mu \mathrm{g} / \mathrm{mL}$ & $\mu \mathrm{g} / \mathrm{mL}$ & $\mathrm{kg}$ \\
\hline \multirow[t]{4}{*}{ ICP.d.AI } & Sample J783 & $(51.6)$ & \multirow{4}{*}{$\begin{array}{l}14.5 \\
\text { to } \\
208\end{array}$} & \multirow[t]{4}{*}{--} & \multirow[t]{4}{*}{87.9} & \multirow[t]{4}{*}{2.33} \\
\hline & Sample J778 & $(77.4)$ & & & & \\
\hline & Sample J775 & $(14.5)$ & & & & \\
\hline & Sample J800 & $(208)$ & & & & \\
\hline Metal (Solid) & & $\mu \mathrm{g} / \mathrm{g}$ & $\mu \mathrm{g} / \mathrm{g}$ & $\mu \mathrm{g} / \mathrm{g}$ & $\mu g / g$ & $\mathrm{~kg}$ \\
\hline \multirow[t]{5}{*}{ ICP.w.AI } & Sample J691 & $(2,710)$ & \multirow{5}{*}{$\begin{array}{c}<94.8 \\
\text { to } \\
2,710\end{array}$} & \multirow[t]{5}{*}{1,150} & & \multirow[t]{19}{*}{14,900} \\
\hline & Sample J704 & $<94.8$ & & & & \\
\hline & Sample J707 & $(824)$ & & & & \\
\hline & Sample $J 711$ & $(1,110)$ & & & & \\
\hline & Sample J712 & $(1,330)$ & & & & \\
\hline \multirow{4}{*}{$\begin{array}{l}\text { ICP.a.AI } \\
\text { Segment } \\
\text { Sample }\end{array}$} & Sample J647 & $(15,800)$ & \multirow{4}{*}{$\begin{array}{c}12,100 \\
\text { to } \\
15,800\end{array}$} & & & \\
\hline & Sample J649 & $(15,300)$ & & & & \\
\hline & Sample $J 658$ & $(12,400)$ & & & & \\
\hline & Sample J656 & $(12,100)$ & & & & \\
\hline \multirow{5}{*}{$\begin{array}{r}\text { ICP.a.AI } \\
\text { Core } \\
\text { Sample }\end{array}$} & Sample J666 & $(14,100)$ & \multirow{5}{*}{$\begin{array}{c}14,000 \\
\text { to } \\
15,400\end{array}$} & \multirow[t]{5}{*}{14,500} & & \\
\hline & Sample J667 & $(14,000)$ & & & & \\
\hline & Sample J672 & $(14,100)$ & & & & \\
\hline & Sample J680 & $(15,400)$ & & & & \\
\hline & Sample J683 & $(15,200)$ & & & & \\
\hline \multirow[t]{5}{*}{ ICP.f.AI } & Sample J715 & $(13,700)$ & \multirow{5}{*}{$\begin{array}{c}13,700 \\
\text { to } \\
15,100\end{array}$} & \multirow[t]{5}{*}{14,300} & & \\
\hline & Sample $J 716$ & $(14,300)$ & & & & \\
\hline & Sample J719 & $(14,000)$ & & & & \\
\hline & Sample J723 & $(15,100)$ & & & & \\
\hline & Sample J724 & $(14,600)$ & & & & \\
\hline
\end{tabular}


Table A-1. Tank 241-C-110 Analytical Data: Antimony

\begin{tabular}{|c|c|c|c|c|c|c|}
\hline Analyte & $\begin{array}{l}\text { Laboratory } \\
\text { Sample } \\
\text { Identification }\end{array}$ & $\begin{array}{c}\text { Analytical } \\
\text { Data } \\
\text { Result }\end{array}$ & $\begin{array}{l}\text { Range } \\
\text { of } \\
\text { Values }\end{array}$ & $\begin{array}{l}\text { Weighted } \\
\text { Mean/ } \\
\text { Standard .: } \\
\text { Error }\end{array}$ & $\begin{array}{c}\text { Evaluated } \\
\text { Data } \\
\text { Result }\end{array}$ & $\begin{array}{l}\text { Projected } \\
\text { Inventory }\end{array}$ \\
\hline Metal (Liquid) & & $\mu \mathrm{g} / \mathrm{mL}$ & $\mu \mathrm{g} / \mathrm{mL}$ & $\mu \mathrm{g} / \mathrm{mL}$ & $\mu \mathrm{g} / \mathrm{mL}$ & $\mathrm{kg}$ \\
\hline \multirow[t]{4}{*}{ ICP.d.Sb } & Sample J783 & $(18.3)$ & \multirow{4}{*}{$\begin{array}{l}18.3 \\
\text { to } \\
37.0\end{array}$} & \multirow[t]{4}{*}{--} & \multirow[t]{4}{*}{23.2} & \multirow[t]{4}{*}{0.615} \\
\hline & Sample J778 & $(18.7)$ & & & & \\
\hline & Sample J775 & $(18.7)$ & & & & \\
\hline & Sample J800 & $(37.0)$ & & & & \\
\hline Metal (Solid) & & $\mu \mathrm{g} / \mathrm{g}$ & $\mu \mathrm{g} / \mathrm{g}$ & $\mu g / g$ & $\mu \mathrm{g} / \mathrm{g}$ & $\mathrm{kg}$ \\
\hline \multirow[t]{5}{*}{ ICP.w.Sb } & Sample J691 & $(37.3)$ & \multirow{5}{*}{$\begin{array}{l}18.0 \\
\text { to } \\
71.7\end{array}$} & \multirow{5}{*}{$\begin{array}{l}36.6 \\
18.3\end{array}$} & \multirow[t]{5}{*}{---} & \multirow[t]{19}{*}{309} \\
\hline & Sample J704 & $(71.7)$ & & & & \\
\hline & Sample J707 & $(18.0)$ & & & & \\
\hline & Sample $J 711$ & $(37.2)$ & & & & \\
\hline & Sample $J 712$ & $(37.2)$ & & & & \\
\hline \multirow{4}{*}{$\begin{array}{l}\text { ICP.a.Sb } \\
\text { Segment } \\
\text { Sample }\end{array}$} & Sample J647 & 29.0 & \multirow{4}{*}{$\begin{array}{l}29.0 \\
\text { to } \\
<36.6\end{array}$} & \multirow[t]{4}{*}{---} & \multirow[t]{4}{*}{---} & \\
\hline & Sample J649 & 32.3 & & & & \\
\hline & Sample J658 & $<36.6$ & & & & \\
\hline & Sample J656 & $<36.6$ & & & & \\
\hline \multirow{5}{*}{$\begin{array}{l}\text { ICP.a.Sb } \\
\text { Core } \\
\text { Sample }\end{array}$} & Sample J666 & $(<17.7)$ & \multirow{5}{*}{$\begin{array}{c}<17.7 \\
\text { to } \\
38.6\end{array}$} & \multirow[t]{5}{*}{33.0} & \multirow[t]{5}{*}{---} & \\
\hline & Sample J667 & $(<17.7)$ & & & & \\
\hline & Sample J672 & $(38.6)$ & & & & \\
\hline & Sample J680 & 25.7 & & & & \\
\hline & Sample J683 & 29.2 & & & & \\
\hline \multirow[t]{5}{*}{ ICP.f.Sb } & Sample J715 & $(219)$ & \multirow{5}{*}{$\begin{array}{c}183 \\
\text { to } \\
383\end{array}$} & \multirow[t]{5}{*}{301} & \multirow[t]{5}{*}{---} & \\
\hline & Sample J716 & (383) & & & & \\
\hline & Sample J719 & $<183$ & & & & \\
\hline & Sample J723 & $<183$ & & & & \\
\hline & Sample J724 & $<183$ & & & & \\
\hline
\end{tabular}


Table A-1. Tank 241-C-110 Analytical Data: Arsenic

\begin{tabular}{|c|c|c|c|c|c|c|}
\hline Analyte $\quad \cdots$ & $\begin{array}{l}\text { Laboratory } \\
\text { :Sample. } \\
\text { Identification }\end{array}$ & $\begin{array}{l}\text { Analytical } \\
\text {. Data } \\
\text { Result }\end{array}$ & $\begin{array}{c}\text { Range } \\
\text { of } \\
\text { Values }\end{array}$ & $\begin{array}{c}\text { Weighted } \\
\text { Mean! } \\
\text { Standard } \\
\text { Error }\end{array}$ & $\begin{array}{c}\text { Evaluated } \\
\text { Data } \\
\text { Result }\end{array}$ & $\begin{array}{l}\text { Projected } \\
\text { Inventory }\end{array}$ \\
\hline Metal (Liquid) & & $\mu \mathrm{g} / \mathrm{mL}$ & $\mu \mathrm{g} / \mathrm{mL}$ & $\mu \mathrm{g} / \mathrm{mL}$ & $\mu \mathrm{g} / \mathrm{mL}$ & $\mathrm{kg}$ \\
\hline \multirow[t]{4}{*}{ ICP.d.As } & Sample $\mathbf{} 783$ & $(1.67)$ & \multirow{4}{*}{$\begin{array}{l}1.53 \\
\text { to } \\
3.03\end{array}$} & \multirow[t]{4}{*}{--} & \multirow[t]{4}{*}{1.94} & \multirow[t]{4}{*}{0.0514} \\
\hline & Sample J778 & $(1.53)$ & & & & \\
\hline & Sample J775 & $(1.53)$ & & & & \\
\hline & Sample J800 & $(3.03)$ & & & & \\
\hline TCLP.ICP.As & Sample J723 & $(<0.151)$ & N/A & & $(<0.151)$ & \\
\hline GHAA.As & Sample J800 & $|0.00735|$ & N/A & & $(0.00735)$ & \\
\hline TCLP.GHAA.As & Sample J723 & 0.0453 & $N / A$ & & 0.0453 & \\
\hline Metal (Solid) & & $\mu \mathrm{g} / \mathrm{g}$ & $\mu g / g$ & $\mu \mathrm{g} / \mathrm{g}$ & $\mu \mathrm{g} / \mathrm{g}$ & $\mathrm{kg}$ \\
\hline \multirow[t]{5}{*}{ ICP.w.As } & Sample J691 & $(3.05)$ & \multirow{5}{*}{$\begin{array}{l}3.05 \\
\text { to } \\
6.73\end{array}$} & \multirow[t]{5}{*}{3.66} & \multirow[t]{5}{*}{--} & \multirow[t]{19}{*}{4.22} \\
\hline & Sample J704 & $(6.73)$ & & & & \\
\hline & Sample J707 & $(3.05)$ & & & & \\
\hline & Sample J711 & $(3.05)$ & & & & \\
\hline & Sample J712 & $(3.05)$ & & & & \\
\hline \multirow{4}{*}{$\begin{array}{l}\text { ICP.a.As } \\
\text { Segment } \\
\text { Sample }\end{array}$} & Sample J647 & $(3.08)$ & \multirow{4}{*}{$\begin{array}{c}<3.00 \\
\text { to } \\
3.13\end{array}$} & \multirow[t]{4}{*}{--} & \multirow[t]{4}{*}{--} & \\
\hline & Sample J649 & $<3.00$ & & & & \\
\hline & Sample J658 & $(3.13)$ & & & & \\
\hline & Sample J656 & $<3.00$ & & & & \\
\hline \multirow{5}{*}{$\begin{array}{r}\text { ICP.a.As } \\
\text { Core } \\
\text { Sample }\end{array}$} & Sample J666 & $(4.50)$ & \multirow{5}{*}{$\begin{array}{c}<2.95 \\
\text { to } \\
4.50\end{array}$} & \multirow[t]{5}{*}{4.11} & \multirow[t]{5}{*}{$\cdots$} & \\
\hline & Sample J667 & $<3.00$ & & & & \\
\hline & Sample J672 & $<3.95 *$ & & & & \\
\hline & Sample J680 & $(3.97)$ & & & & \\
\hline & Sample J683 & $(3.47)$ & & & & \\
\hline \multirow[t]{5}{*}{ ICP.f.As } & Sample J715 & $(<15.0)$ & \multirow[t]{5}{*}{ N/A } & \multirow[t]{5}{*}{--} & \multirow[t]{5}{*}{$<15.0$} & \\
\hline & Sample J716 & $<15.01$ & & & & \\
\hline & Sample J719 & $(<15.0)$ & & & & \\
\hline & Sample J723 & $<15.0$ & & & & \\
\hline & Sample J724 & $<15.01$ & & & & \\
\hline
\end{tabular}

- Blank Contamination 
Table A-1. Tank 241-C-110 Analytical Data: Arsenic (cont.)

\begin{tabular}{|c|c|c|c|c|c|c|}
\hline$\therefore$ Analyte & $\begin{array}{l}\text { Laboratory } \\
\text { Sample } \\
\text { Identification }\end{array}$ & $\begin{array}{l}\text { Analytical } \\
\text { DData } \\
\text { :Result }\end{array}$ & $\begin{array}{l}\text { Range } \\
: \quad \text { of } \\
: \text { Values }\end{array}$ & $\begin{array}{l}\text { Weighted } \\
\text { Mean/ } \\
\text { Standard: } \\
\text { Error }\end{array}$ & $\begin{array}{l}\text { Evaluated } \\
\text { Data } \\
\text { Result }\end{array}$ & $\begin{array}{l}\text { Projected } \\
\text { Inventory }\end{array}$ \\
\hline Metal (Solid) & & $\mu \mathrm{g} / \mathrm{g}$ & $\mu \mathrm{g} / \mathrm{g}$ & $\mu \mathrm{g} / \mathrm{g}$ & $\mu g / g$ & $\mathrm{~kg}$ \\
\hline \multirow[t]{5}{*}{ GHAA.As } & Sample J666 & $(0.340)$ & \multirow{5}{*}{$\begin{array}{c}<0.250 \\
\text { to } \\
0.677\end{array}$} & \multirow[t]{5}{*}{0.503} & \multirow[t]{5}{*}{-} & \multirow[t]{5}{*}{--} \\
\hline & Sample J667 & $<0.250$ & & & & \\
\hline & Sample J672 & 0.677 & & & & \\
\hline & Sample $J 680$ & $(0.446)$ & & & & \\
\hline & Sample J683 & $(0.535)$ & & & & \\
\hline
\end{tabular}


Table A-1. Tank 241-C-110 Analytical Data: Barium

\begin{tabular}{|c|c|c|c|c|c|c|}
\hline $\begin{array}{l}\text { Analyte } \\
\therefore\end{array}$ & $\begin{array}{l}\text { Laboratory } \\
\text { Sample } \\
\text { Identification }\end{array}$ & $\begin{array}{c}\text { Analytical } \\
\text { Data } \\
\text { Result }\end{array}$ & $\begin{array}{c}\text { Range } \\
\text { of } \\
\text { Values }\end{array}$ & $\begin{array}{c}\text { Weighted } \\
\text { Mean/ } \\
\text { Standard } \\
\text { Error }\end{array}$ & $\begin{array}{c}\text { Evaluated } \\
\text { Data } \\
\text { Result }\end{array}$ & $\begin{array}{l}\text { Projected } \\
\text { Inventory }\end{array}$ \\
\hline Metal (Liquid) & & $\mu \mathrm{g} / \mathrm{mL}$ & $\mu \mathrm{g} / \mathrm{mL}$ & $\mu \mathrm{g} / \mathrm{mL}$ & $\mu \mathrm{g} / \mathrm{mL}$ & $\mathrm{kg}$ \\
\hline \multirow[t]{4}{*}{ ICP.d.Ba } & Sample J783 & $(<0.150)$ & \multirow{4}{*}{$\begin{array}{l}<0.150 \\
\text { to } \\
<0.303\end{array}$} & \multirow[t]{4}{*}{---} & \multirow[t]{4}{*}{$<0.303$} & \multirow[t]{5}{*}{$<0.00803$} \\
\hline & Sample J778 & $(<0.153)$ & & & & \\
\hline & Sample J775 & $(<0.153)$ & & & & \\
\hline & Sample J800 & $(<0.303)$ & & & & \\
\hline TCLP.ICP.Ba & Sample J723 & $<0.0966$ & $N / A$ & & $<0.0966$ & \\
\hline Metal (Solid) & & $\mu \mathrm{g} / \mathrm{g}$ & $\mu \mathrm{g} / \mathrm{g}$ & $\mu \mathrm{g} / \mathrm{g}$ & $\mu g / g$ & $\mathrm{~kg}$ \\
\hline \multirow[t]{5}{*}{ ICP.w.Ba } & Sample J691 & $(2.68)$ & \multirow{5}{*}{$\begin{array}{c}<0.305 \\
\text { to } \\
2.68\end{array}$} & \multirow[t]{5}{*}{1.59} & \multirow[t]{5}{*}{$\cdots$} & \multirow[t]{19}{*}{8.75} \\
\hline & Sample $\mathrm{J} 704$ & $(<0.604)$ & & & & \\
\hline & Sample J707 & $(0.505)$ & & & & \\
\hline & Sample J711 & $(<0.305)$ & & & & \\
\hline & Sample J712 & $(<0.305)$ & & & & \\
\hline \multirow{4}{*}{$\begin{array}{l}\text { ICP.a.Ba } \\
\text { Segment } \\
\text { Sample }\end{array}$} & Sample J647 & $(8.89)$ & \multirow{4}{*}{$\begin{array}{l}4.35 \\
\text { to } \\
8.95\end{array}$} & \multirow[t]{4}{*}{$\cdots$} & \multirow[t]{4}{*}{$\cdots$} & \\
\hline & Sample J649 & $(8.95)$ & & & & \\
\hline & Sample $J 658$ & $(4.78)$ & & & & \\
\hline & Sample J656 & $(4.35)$ & & & & \\
\hline \multirow{5}{*}{$\begin{array}{r}\text { ICP.a.Ba } \\
\text { Core } \\
\text { Sample }\end{array}$} & Sample J666 & $(8.91)$ & \multirow{5}{*}{$\begin{array}{l}5.57 \\
\text { to } \\
9.00\end{array}$} & \multirow[t]{5}{*}{7.68} & \multirow[t]{5}{*}{$\cdots$} & \\
\hline & Sample J667 & $(9.00)$ & & & & \\
\hline & Sample J672 & $(8.39)$ & & & & \\
\hline & Sample J680 & $(5.57)$ & & & & \\
\hline & Sample J683 & $(5.82)$ & & & & \\
\hline \multirow[t]{5}{*}{ ICP.f.Ba } & Sample J715 & $(8.11)$ & \multirow{5}{*}{$\begin{array}{l}6.49 \\
\text { to } \\
9.46\end{array}$} & \multirow{5}{*}{0.930} & \multirow[t]{5}{*}{---} & \\
\hline & Sample J716 & $(8.89)$ & & & & \\
\hline & Sample J719 & $(9.46)$ & & & & \\
\hline & Sample J723 & $(6.49)$ & & & & \\
\hline & Sample J724 & $(8.41)$ & & & & \\
\hline
\end{tabular}


WHC-SD-WM-ER-367 REV O

Table A-1. Tank 241-C-110 Analytical Data: Beryllium

\begin{tabular}{|c|c|c|c|c|c|c|}
\hline Analyte & $\begin{array}{l}\text { Laboratory } \\
\text { Sample } \\
\text { Identification }\end{array}$ & $\begin{array}{l}\text { Analytical } \\
\text { Data } \\
\text { Result }\end{array}$ & $\begin{array}{l}\text { Range } \\
\text { of } \\
\text { Values }\end{array}$ & $\begin{array}{l}\text { Weighted } \\
\text { Mean/ } \\
\text { Standard } \\
\text { Error }\end{array}$ & $\begin{array}{c}\text { Evaluated } \\
\text { Data } \\
\text { Result }\end{array}$ & $\begin{array}{l}\text { Projected } \\
\text { Inventory } \\
\text {. }\end{array}$ \\
\hline Metal (Liquid) & & $\mu \mathrm{g} / \mathrm{mL}$ & $\mu \mathrm{g} / \mathrm{mL}$ & $\mu \mathrm{g} / \mathrm{mL}$ & $\mu \mathrm{g} / \mathrm{mL}$ & $\mathrm{kg}$ \\
\hline \multirow[t]{4}{*}{ ICP.d.Be } & Sample J783 & $(0.150)$ & \multirow{4}{*}{$\begin{array}{c}0.150 \\
\text { to } \\
0.303\end{array}$} & \multirow[t]{4}{*}{--} & \multirow[t]{4}{*}{0.190} & \multirow[t]{4}{*}{0.00504} \\
\hline & Sample J778 & $(0.153)$ & & & & \\
\hline & Sample J775 & $(0.153)$ & & & & \\
\hline & Sample J800 & $(0.303)$ & & & & \\
\hline Metal (Solid) & & $\mu \mathrm{g} / \mathrm{g}$ & $\mu \mathrm{g} / \mathrm{g}$ & $\mu \mathrm{g} / \mathrm{g}$ & $\mu \mathrm{g} / \mathrm{g}$ & $\mathrm{kg}$ \\
\hline \multirow[t]{5}{*}{ ICP.w.Be } & Sample J691 & $(0.305)$ & \multirow{5}{*}{$\begin{array}{c}0.102 \\
\text { to } \\
0.604\end{array}$} & \multirow[t]{2}{*}{0.287} & \multirow[t]{5}{*}{--} & \multirow[t]{19}{*}{0.295} \\
\hline & Sample J704 & $(0.604)$ & & & & \\
\hline & Sample J707 & $(0.102)$ & & 0.177 & & \\
\hline & Sample J711 & $(0.305)$ & & & & \\
\hline & Sample J712 & $(0.305)$ & & & & \\
\hline \multirow{4}{*}{$\begin{array}{r}\text { ICP.a.Be } \\
\text { Segment } \\
\text { Sample }\end{array}$} & Sample J647 & $<0.100$ & \multirow[t]{4}{*}{ N/A } & \multirow[t]{4}{*}{---} & \multirow[t]{4}{*}{--} & \\
\hline & Sample J649 & $<0.100)$ & & & & \\
\hline & Sample J658 & $<0.300$ & & & & \\
\hline & Sample J656 & $<0.300)$ & & & & \\
\hline \multirow{5}{*}{$\begin{array}{c}\text { ICP.a.Be } \\
\text { Core } \\
\text { Sample }\end{array}$} & Sample J666 & $1<0.100)$ & \multirow[t]{5}{*}{ N/A } & \multirow[t]{5}{*}{$\cdots$} & \multirow[t]{5}{*}{$<0.300$} & \\
\hline & Sample J667 & $<0.100$ & & & & \\
\hline & Sample J672 & $<0.300$ & & & & \\
\hline & Sample J680 & $<0.100$ & & & & \\
\hline & Sample J683 & $<0.100$ & & & & \\
\hline \multirow[t]{5}{*}{ ICP.f.Be } & Sample J715 & $1<1.50)$ & \multirow[t]{5}{*}{ N/A } & \multirow[t]{5}{*}{$-\cdots$} & \multirow[t]{5}{*}{$<1.50$} & \\
\hline & Sample J716 & $<1.50$ & & & & \\
\hline & Sample $\mathrm{J719}$ & $1<1.50)$ & & & & \\
\hline & Sample $\mathrm{J} 723$ & $<1.50$ & & & & \\
\hline & Sample J724 & $<1.50$ & & & & \\
\hline
\end{tabular}


Table A-1. Tank 241-C-110 Analytical Data: Bismuth

\begin{tabular}{|c|c|c|c|c|c|c|}
\hline Analyte & $\begin{array}{l}\text { Laboratory } \\
\text { Sample } \\
\text { Identification }\end{array}$ & $\begin{array}{l}\text { Analytical } \\
\text { Data } \\
\text { Result }\end{array}$ & $\begin{array}{l}\text { Range } \\
\text { of } \\
\text { Values }\end{array}$ & $\begin{array}{l}\text { Weighted } \\
\text { Meanl } \\
\text { Stañdard } \\
\text { Error }\end{array}$ & $\begin{array}{l}\text { Evaluated } \\
\text { Data } \\
\text { Result }\end{array}$ & $\begin{array}{l}\text { Projected } \\
\text { Inventory }\end{array}$ \\
\hline Metal (Liquid) & & $\mu \mathrm{g} / \mathrm{mL}$ & $\mu \mathrm{g} / \mathrm{mL}$ & $\mu \mathrm{g} / \mathrm{mL}$ & $\mu \mathrm{g} / \mathrm{mL}$ & $\mathrm{kg}$ \\
\hline \multirow[t]{4}{*}{ ICP.d.Bi } & Sample J783 & $(3.86)$ & \multirow{4}{*}{$\begin{array}{c}3.86 \\
\text { to } \\
192\end{array}$} & \multirow[t]{4}{*}{--} & \multirow[t]{4}{*}{63.5} & \multirow[t]{4}{*}{1.68} \\
\hline & Sample J778 & $(38.5)$ & & & & \\
\hline & Sample J775 & $(19.7)$ & & & & \\
\hline & Sample J800 & $(192)$ & & & & \\
\hline Metal (Solid) & & $\mu \mathrm{g} / \mathrm{g}$ & $\mu \mathrm{g} / \mathrm{g}$ & $\mu \mathrm{g} / \mathrm{g}$ & $\mu g / g$ & $\mathrm{~kg}$ \\
\hline \multirow[t]{5}{*}{ ICP.w.Bi } & Sample J691 & $(102)$ & \multirow{5}{*}{$\begin{array}{c}39.1 \\
\text { to } \\
102\end{array}$} & \multirow[t]{5}{*}{68.3} & \multirow[t]{5}{*}{--} & \multirow[t]{19}{*}{17,200} \\
\hline & Sample $J 704$ & $(39.1)$ & & & & \\
\hline & Sample J707 & $(56.6)$ & & & & \\
\hline & Sample J711 & $(82.8)$ & & & & \\
\hline & Sample $\mathrm{J} 712$ & $(72.9)$ & & & & \\
\hline \multirow{4}{*}{$\begin{array}{l}\text { ICP.a.Bi } \\
\text { Segment } \\
\text { Sample }\end{array}$} & Sample J647 & $(16,900)$ & \multirow{4}{*}{$\begin{array}{c}12,000 \\
\text { to } \\
18,100\end{array}$} & \multirow[t]{4}{*}{--- } & \multirow[t]{4}{*}{--} & \\
\hline & Sample J649 & $(16,800)$ & & & & \\
\hline & Sample J658 & $(12,800)$ & & & & \\
\hline & Sample J656 & $(12,000)$ & & & & \\
\hline \multirow{5}{*}{$\begin{array}{r}\text { ICP.a.Bi } \\
\text { Core } \\
\text { Sample }\end{array}$} & Sample J666 & $(17,700)$ & \multirow{5}{*}{$\begin{array}{c}14,400 \\
\text { to } \\
18,100\end{array}$} & \multirow{5}{*}{$\begin{array}{r}16,800 \\
1,180\end{array}$} & \multirow[t]{5}{*}{---} & \\
\hline & Sample J667 & $(17,900)$ & & & & \\
\hline & Sample J672 & $(18,100)$ & & & & \\
\hline & Sample J680 & $(14,400)$ & & & & \\
\hline & Sample J683 & $(14,400)$ & & & & \\
\hline \multirow[t]{5}{*}{ ICP.f.Bi } & Sample J715 & $(12,700)$ & \multirow{5}{*}{$\begin{array}{c}11,800 \\
\text { to } \\
15,400\end{array}$} & \multirow[t]{5}{*}{13,700} & \multirow[t]{5}{*}{---} & \\
\hline & Sample $\mathrm{J716}$ & $(13,100)$ & & & & \\
\hline & Sample J719 & $(15,400)$ & & & & \\
\hline & Sample J723 & $(14,000)$ & & & & \\
\hline & Sample J724 & $(11,800)$ & & & & \\
\hline
\end{tabular}


Table A-1. Tank 241-C-110 Analytical Data: Boron

\begin{tabular}{|c|c|c|c|c|c|c|}
\hline Analyte & $\begin{array}{l}\text { Laboratory } \\
\text { Sample } \\
\text { Identification }\end{array}$ & $\begin{array}{c}\text { Analytical } \\
\text { Data } \\
\text { Result }\end{array}$ & $\begin{array}{l}\text { Range } \\
\text {.of } \\
\text { Values }\end{array}$ & $\begin{array}{c}\text { Weighted } \\
\text { Mean/ } \\
\text { Standard } \\
\text { Error }\end{array}$ & $\begin{array}{c}\text { Evaluated } \\
\text { Data } \\
\text { Result }\end{array}$ & $\begin{array}{l}\text { Projected } \\
\text { Inventory }\end{array}$ \\
\hline Metal (Liquid) & & $\mu \mathrm{g} / \mathrm{mL}$ & $\mu \mathrm{g} / \mathrm{mL}$ & $\mu \mathrm{g} / \mathrm{mL}$ & $\mu \mathrm{g} / \mathrm{mL}$ & $\mathrm{kg}$ \\
\hline \multirow[t]{4}{*}{ ICP.d.B } & Sample J783 & $(5.65)$ & \multirow{4}{*}{$\begin{array}{l}5.65 \\
\text { to } \\
23.6\end{array}$} & \multirow[t]{4}{*}{--} & \multirow[t]{4}{*}{15.7} & \multirow[t]{4}{*}{0.416} \\
\hline & Sample J778 & $(23.6)$ & & & & \\
\hline & Sample J775 & $(22.8)$ & & & & \\
\hline & Sample 1800 & $(10.9)$ & & & & \\
\hline Metal (Solid) & & $\mu \mathrm{g} / \mathrm{g}$ & $\mu \mathrm{g} / \mathrm{g}$ & $\mu \mathrm{g} / \mathrm{g}$ & $\mu \mathrm{g} / \mathrm{g}$ & $\mathrm{kg}$ \\
\hline \multirow[t]{5}{*}{ ICP.w.B } & Sample J691 & 28.2 & \multirow{5}{*}{$\begin{array}{l}14.4 \\
\text { to } \\
28.6\end{array}$} & \multirow[t]{5}{*}{25.0} & \multirow[t]{5}{*}{$\cdots$} & \multirow[t]{19}{*}{25.7} \\
\hline & Sample J704 & 14.4 & & & & \\
\hline & Sampie J707 & $(25.6)$ & & & & \\
\hline & Sample J711 & 28.6 & & & & \\
\hline & Sample $J 712$ & 27.5 & & & & \\
\hline \multirow{4}{*}{$\begin{array}{l}\text { ICP.a.B } \\
\text { Segment } \\
\text { Sample }\end{array}$} & Sample J647 & 28.2 & \multirow{4}{*}{$\begin{array}{c}<28.2 \\
\text { to } \\
29.8\end{array}$} & \multirow[t]{4}{*}{--} & \multirow[t]{4}{*}{--} & \\
\hline & Sample J649 & 29.8 & & & & \\
\hline & Sample J658 & $<28.5$ & & & & \\
\hline & Sample J656 & $<28.2$ & & & & \\
\hline \multirow{5}{*}{$\begin{array}{l}\text { ICP.a.B } \\
\text { Core } \\
\text { Sample }\end{array}$} & Sample J666 & 23.9 & \multirow{5}{*}{$\begin{array}{l}17.3 \\
\text { to } \\
25.2\end{array}$} & \multirow[t]{2}{*}{21.2} & \multirow[t]{5}{*}{--} & \\
\hline & Sample J667 & 25.2 & & & & \\
\hline & Sample J672 & 17.3 & & 2.07 & & \\
\hline & Sample J680 & 20.8 & & & & \\
\hline & Sample J683 & 22.7 & & & & \\
\hline \multirow[t]{5}{*}{ ICP.f.B } & Sample $J 715$ & $(7.49)$ & \multirow{5}{*}{$\begin{array}{l}7.31 \\
\text { to } \\
22.3\end{array}$} & \multirow[t]{5}{*}{11.9} & \multirow[t]{5}{*}{$\cdots$} & \\
\hline & Sample J716 & $(7.31)$ & & & & \\
\hline & Sample $J 719$ & $(16.4)$ & & & & \\
\hline & Sample J723 & $<16.8$ & & & & \\
\hline & Sample J724 & $<22.3$ & & & & \\
\hline
\end{tabular}


Table A-1. Tank 241-C-110 Analytical Data: Cadmium

\begin{tabular}{|c|c|c|c|c|c|c|}
\hline Analyte & $\begin{array}{l}\text { Laboratory } \\
\text { Sample } \\
\text { Identification }\end{array}$ & $\begin{array}{l}\text { Analytical } \\
\text { : Data } \\
\text { Result }\end{array}$ & $\begin{array}{l}\text { Range } \\
\text { of } \\
\text { Values }\end{array}$ & $\begin{array}{l}\text { Weighted } \\
\text { Meanl } \\
\text { Standärd } \\
\text { Error }\end{array}$ & $\begin{array}{l}\text { Evaluated } \\
\text { Data } \\
\text { Result }\end{array}$ & $\begin{array}{l}\text { Projected } \\
\text { Inventory }\end{array}$ \\
\hline Metal (Liquid) & & $\mu \mathrm{g} / \mathrm{mL}$ & $\mu \mathrm{g} / \mathrm{mL}$ & $\mu \mathrm{g} / \mathrm{mL}$ & $\mu \mathrm{g} / \mathrm{mL}$ & $\mathrm{kg}$ \\
\hline \multirow[t]{4}{*}{ ICP.d.Cd } & Sample J783 & $(0.350)$ & \multirow{4}{*}{$\begin{array}{l}0.350 \\
\text { to } \\
0.707\end{array}$} & \multirow[t]{4}{*}{--} & \multirow[t]{4}{*}{0.443} & \multirow[t]{5}{*}{0.0117} \\
\hline & Sample J778 & $(0.357)$ & & & & \\
\hline & Sample J775 & $(0.357)$ & & & & \\
\hline & Sample J800 & $(0.707)$ & & & & \\
\hline TCLP.ICP.Cd & Sample J723 & $(<0.0353)$ & N/A & & $<0.0353$ & \\
\hline Metal (Solid) & & $\mu \mathrm{g} / \mathrm{g}$ & $\mu \mathrm{g} / \mathrm{g}$ & $\mu \mathrm{g} / \mathrm{g}$ & $\mu \mathrm{g} / \mathrm{g}$ & $\mathrm{kg}$ \\
\hline \multirow[t]{5}{*}{ ICP.w.Cd } & Sample J691 & $(0.750)$ & \multirow{5}{*}{$\begin{array}{l}0.711 \\
\text { to } \\
1.41\end{array}$} & \multirow[t]{2}{*}{0.756} & \multirow[t]{5}{*}{--} & \multirow[t]{19}{*}{5.50} \\
\hline & Sample J704 & $(1.41)$ & & & & \\
\hline & Sample J707 & $(0.478)$ & & \multirow[t]{3}{*}{0.304} & & \\
\hline & Sample J711 & $(0.711)$ & & & & \\
\hline & Sample J712 & $(0.711)$ & & & & \\
\hline \multirow{4}{*}{$\begin{array}{l}\text { ICP.a.Cd } \\
\text { Segment } \\
\text { Sample }\end{array}$} & Sample J647 & $(3.59)$ & \multirow{4}{*}{$\begin{array}{l}1.56 \\
\text { to } \\
3.68\end{array}$} & \multirow[t]{4}{*}{--- } & \multirow[t]{4}{*}{--} & \\
\hline & Sample J649 & $(3.68)$ & & & & \\
\hline & Sample J658 & $(1.88)$ & & & & \\
\hline & Sample J656 & $(1.56)$ & & & & \\
\hline \multirow{5}{*}{$\begin{array}{c}\text { ICP.a.Cd } \\
\text { Core } \\
\text { Sample }\end{array}$} & Sample J666 & $(2.66)$ & \multirow{5}{*}{$\begin{array}{l}1.98 \\
\text { to } \\
4.76\end{array}$} & \multirow[t]{5}{*}{3.23} & \multirow[t]{5}{*}{--} & \\
\hline & Sample J667 & $(2.78)$ & & & & \\
\hline & Sample J672 & $(4.76)$ & & & & \\
\hline & Sample J680 & $(1.98)$ & & & & \\
\hline & Sample J683 & $(2.46)$ & & & & \\
\hline \multirow[t]{5}{*}{ ICP.f.Cd } & Sample J715 & $(4.69)$ & \multirow{5}{*}{$\begin{array}{l}3.79 \\
\text { to } \\
6.16\end{array}$} & \multirow{5}{*}{0.693} & \multirow[t]{5}{*}{--} & \\
\hline & Sample J716 & $(5.22)$ & & & & \\
\hline & Sample J719 & $(6.16)$ & & & & \\
\hline & Sample J723 & $(3.79)$ & & & & \\
\hline & Sample J724 & $(6.13)$ & & & & \\
\hline
\end{tabular}


Table A-1. Tank 241-C-110 Analytical Data: Calcium

\begin{tabular}{|c|c|c|c|c|c|c|}
\hline Analyte & $\begin{array}{l}\text { Laboratory } \\
\text { Sample } \\
\text { Identification }\end{array}$ & $\begin{array}{l}\text { Analytical } \\
\text { :Data } \\
\text { Result }\end{array}$ & $\begin{array}{l}\text { Range } \\
\text {. of } \\
\text { Values }\end{array}$ & $\begin{array}{c}\text { Weighted } \\
\text { Mean/ } \\
\text { Standard } \\
\text { Error }\end{array}$ & $\begin{array}{c}\text { Evaluated } \\
\text { Data } \\
\text { Result }\end{array}$ & $\begin{array}{l}\text { Projected } \\
\text { Inventory }\end{array}$ \\
\hline Metal (Liquid) & & $\mu \mathrm{g} / \mathrm{mL}$ & $\mu \mathrm{g} / \mathrm{mL}$ & $\mu \mathrm{g} / \mathrm{mL}$ & $\mu \mathrm{g} / \mathrm{mL}$ & $\mathrm{kg}$ \\
\hline \multirow[t]{4}{*}{ ICP.d.Ca } & Sample J783 & $(13.6)$ & \multirow{4}{*}{$\begin{array}{l}13.6 \\
\text { to } \\
27.5\end{array}$} & \multirow[t]{4}{*}{$\cdots$} & \multirow[t]{4}{*}{17.2} & \multirow[t]{4}{*}{0.456} \\
\hline & Sample J778 & $(13.9)$ & & & & \\
\hline & Sample $\mathbf{J 7 7 5}$ & $(13.9)$ & & & & \\
\hline & Sample $J 800$ & $(27.5)$ & & & & \\
\hline Metal (Solid) & & $\mu \mathrm{g} / \mathrm{g}$ & $\mu \mathrm{g} / \mathrm{g}$ & $\mu \mathrm{g} / \mathrm{g}$ & $\mu g / g$ & $\mathrm{~kg}$ \\
\hline \multirow[t]{5}{*}{ ICP.w.Ca } & Sample J691 & 119 & \multirow{5}{*}{$\begin{array}{c}<35.0 \\
\text { to } \\
299\end{array}$} & \multirow[t]{5}{*}{154} & \multirow[t]{5}{*}{--} & \multirow[t]{19}{*}{1,180} \\
\hline & Sample J704 & 299 & & & & \\
\hline & Sample J707 & $(211)$ & & & & \\
\hline & Sample J711 & $\{<51.2\}$ & & & & \\
\hline & Sample J712 & $1<35.0)$ & & & & \\
\hline \multirow{4}{*}{$\begin{array}{l}\text { ICP.a.Ca } \\
\text { Segment } \\
\text { Sample }\end{array}$} & Sample J647 & $<429$ & \multirow[t]{4}{*}{$N / A^{*}$} & \multirow[t]{4}{*}{---} & \multirow[t]{4}{*}{--} & \\
\hline & Sample J649 & $<1,190$ & & & & \\
\hline & Sample J658 & $<1,910$ & & & & \\
\hline & Sample J656 & 243 & & & & \\
\hline \multirow{5}{*}{$\begin{array}{r}\text { ICP.a.Ca } \\
\text { Core } \\
\text { Sample }\end{array}$} & Sample J666 & 833 & \multirow{5}{*}{$\begin{array}{l}183 \\
\text { to } \\
833\end{array}$} & \multirow[t]{5}{*}{381} & \multirow[t]{5}{*}{--} & \\
\hline & Sample J667 & 598 & & & & \\
\hline & Sample J672 & 243 & & & & \\
\hline & Sample J680 & 186 & & & & \\
\hline & Sample $J 683$ & 183 & & & & \\
\hline \multirow[t]{5}{*}{ ICP.f.Ca } & Sample J715 & 1,250 & \multirow{5}{*}{$\begin{array}{c}<403 \\
\text { to } \\
2,600\end{array}$} & \multirow[t]{5}{*}{1,150} & \multirow[t]{5}{*}{$\cdots$} & \\
\hline & Sample J716 & 585 & & & & \\
\hline & Sample J719 & 1,020 & & & & \\
\hline & Sample J723 & $<403$ & & & & \\
\hline & Sample J724 & 2,600 & & & & \\
\hline
\end{tabular}

- Blank Contamination 
Table A-1. Tank 241-C-110 Analytical Data: Cerium

\begin{tabular}{|c|c|c|c|c|c|c|}
\hline Analyte & $\begin{array}{c}\text { Laboratory } \\
\text { Sample } \\
\text { Identification }\end{array}$ & $\begin{array}{l}\text { Analytical } \\
\text { Data } \\
\text { Result }\end{array}$ & $\begin{array}{c}\text { Range } \\
\text { of } \\
\text { Values }\end{array}$ & $\begin{array}{l}\text { Weighted } \\
\text { Mean/ } \\
\text { Standard } \\
\text { Error }\end{array}$ & $\begin{array}{c}\text { Evaluated } \\
\text { Data } \\
\text { Result }\end{array}$ & $\begin{array}{l}\text { Projected } \\
\text { Inventory }\end{array}$ \\
\hline Metal (Liquid) & & $\mu \mathrm{g} / \mathrm{mL}$ & $\mu \mathrm{g} / \mathrm{mL}$ & $\mu \mathrm{g} / \mathrm{mL}$ & $\mu \mathrm{g} / \mathrm{mL}$ & $\mathrm{kg}$ \\
\hline \multirow[t]{4}{*}{ ICP.d.Ce } & Sample J783 & $(4.90)$ & \multirow{4}{*}{$\begin{array}{l}4.90 \\
\text { to } \\
9.90\end{array}$} & \multirow[t]{4}{*}{-} & \multirow[t]{4}{*}{6.20} & \multirow[t]{4}{*}{0.164} \\
\hline & Sample J778 & $(5.00)$ & & & & \\
\hline & Sample 3775 & $(5.00)$ & & & & \\
\hline & Sample $J 800$ & $(9.90)$ & & & & \\
\hline Metal (Solid) & & $\mu \mathrm{g} / \mathrm{g}$ & $\mu \mathrm{g} / \mathrm{g}$ & $\mu \mathrm{g} / \mathrm{g}$ & $\mu \mathrm{g} / \mathrm{g}$ & $\mathrm{kg}$ \\
\hline \multirow[t]{5}{*}{ ICP.w.Ce } & Sample J691 & $(41.5)$ & \multirow{5}{*}{$\begin{array}{l}9.95 \\
\text { to } \\
41.5\end{array}$} & \multirow[t]{2}{*}{16.6} & \multirow[t]{5}{*}{$\cdots$} & \multirow[t]{19}{*}{216} \\
\hline & Sample J704 & $(17.3)$ & & & & \\
\hline & Sample $\mathrm{J} 707$ & $(10.3)$ & & 11.1 & & \\
\hline & Sample J711 & $(9.95)$ & & & & \\
\hline & Sample J712 & $(9.96)$ & & & & \\
\hline \multirow{4}{*}{$\begin{array}{l}\text { ICP.a.Ce } \\
\text { Segment } \\
\text { Sample }\end{array}$} & Sample J647 & $(215)$ & \multirow{4}{*}{$\begin{array}{c}141 \\
\text { to } \\
215\end{array}$} & \multirow[t]{4}{*}{--- } & \multirow[t]{4}{*}{--} & \\
\hline & Sample J649 & $(213)$ & & & & \\
\hline & Sample J658 & $(156)$ & & & & \\
\hline & Sample J656 & $(141)$ & & & & \\
\hline \multirow{5}{*}{$\begin{array}{r}\text { ICP.a.Ce } \\
\text { Core } \\
\text { Sample }\end{array}$} & Sample J666 & $(219)$ & \multirow{5}{*}{$\begin{array}{l}178 \\
\text { to } \\
226\end{array}$} & \multirow{5}{*}{13.4} & \multirow[t]{5}{*}{--} & \\
\hline & Sample J667 & $(220)$ & & & & \\
\hline & Sample J672 & $(226)$ & & & & \\
\hline & Sample J680 & $(178)$ & & & & \\
\hline & Sample J683 & $(188)$ & & & & \\
\hline \multirow[t]{5}{*}{ ICP.f.Ce } & Sample J715 & $(184)$ & \multirow{5}{*}{$\begin{array}{l}150 \\
\text { to } \\
214\end{array}$} & \multirow[t]{5}{*}{175} & \multirow[t]{5}{*}{---} & \\
\hline & Sample J716 & $(150)$ & & & & \\
\hline & Sample J719 & $(170)$ & & & & \\
\hline & Sample J723 & $(214)$ & & & & \\
\hline & Sample J724 & $(162)$ & & & & \\
\hline
\end{tabular}


Table A-1. Tank 241-C-110 Analytical Data: Chromium

\begin{tabular}{|c|c|c|c|c|c|c|}
\hline Analyte & $\begin{array}{l}\text { Laboratory } \\
\text { Sample } \\
\text { Identification }\end{array}$ & $\begin{array}{c}\text { Analytical } \\
\text { Data } \\
\text { Result }\end{array}$ & $\begin{array}{l}\text { Range } \\
\text { of } \\
\text { Values }\end{array}$ & $\begin{array}{c}\text { Weighted } \\
\text { Mean/ } \\
\text { Standard } \\
\text { Error }\end{array}$ & $\begin{array}{c}\text { Evaluated } \\
\text { Data } \\
\text { Result }\end{array}$ & $\begin{array}{l}\text { Projected } \\
\text { Inventory }\end{array}$ \\
\hline Metal (Liquid) & & $\mu \mathrm{g} / \mathrm{mL}$ & $\mu \mathrm{g} / \mathrm{mL}$ & $\mu \mathrm{g} / \mathrm{mL}$ & $\mu \mathrm{g} / \mathrm{mL}$ & $\mathrm{kg}$ \\
\hline \multirow[t]{4}{*}{ ICP.d.Cr } & Sample J783 & $(3 \uparrow .4)$ & \multirow{4}{*}{$\begin{array}{c}31.4 \\
\text { to } \\
393\end{array}$} & \multirow[t]{4}{*}{--} & \multirow[t]{4}{*}{173} & \multirow[t]{5}{*}{4.58} \\
\hline & Sample J778 & $(150)$ & & & & \\
\hline & Sample J775 & (393) & & & & \\
\hline & Sample J800 & $(119)$ & & & & \\
\hline TCLP.ICP.Cr & Sample J723 & $(13.3)$ & N/A & & 13.3 & \\
\hline Metal (Solid) & & $\mu \mathrm{g} / \mathrm{g}$ & $\mu g / g$ & $\mu \mathrm{g} / \mathrm{g}$ & $\mu g / g$ & $\mathrm{~kg}$ \\
\hline \multirow[t]{5}{*}{ ICP.w.Cr } & Sample J691 & $(294)$ & \multirow{5}{*}{$\begin{array}{l}27.5 \\
\text { to } \\
294\end{array}$} & \multirow{5}{*}{52.1} & \multirow[t]{5}{*}{$\cdots$} & \multirow[t]{19}{*}{483} \\
\hline & Sample J704 & $(27.5)$ & & & & \\
\hline & Sample J707 & $(185)$ & & & & \\
\hline & Sample J711 & $(275)$ & & & & \\
\hline & Sample J712 & $(269)$ & & & & \\
\hline \multirow{4}{*}{$\begin{array}{l}\text { ICP.a.Cr } \\
\text { Segment } \\
\text { Sample }\end{array}$} & Sample J647 & $(555)$ & \multirow{4}{*}{$\begin{array}{c}312 \\
\text { to } \\
559\end{array}$} & \multirow[t]{4}{*}{---} & \multirow[t]{4}{*}{-- } & \\
\hline & Sample J649 & $(559)$ & & & & \\
\hline & Sample J658 & $(321)$ & & & & \\
\hline & Sample J656 & $(312)$ & & & & \\
\hline \multirow{5}{*}{$\begin{array}{c}\text { ICP.a.Cr } \\
\text { Core } \\
\text { Sample }\end{array}$} & Sample J666 & $(492)$ & \multirow{5}{*}{$\begin{array}{c}429 \\
\text { to } \\
493\end{array}$} & \multirow[t]{5}{*}{470} & \multirow[t]{5}{*}{$\cdots$} & \\
\hline & Sample J667 & $(493)$ & & & & \\
\hline & Sample J672 & $(488)$ & & & & \\
\hline & Sample J680 & $(431)$ & & & & \\
\hline & Sample J683 & $(429)$ & & & & \\
\hline \multirow[t]{5}{*}{ ICP.f.Cr } & Sample J715 & $(478)$ & \multirow{5}{*}{$\begin{array}{l}417 \\
\text { to } \\
496\end{array}$} & \multirow[t]{5}{*}{464} & \multirow[t]{5}{*}{--} & \\
\hline & Sample J716 & (469) & & & & \\
\hline & Sample J719 & $(496)$ & & & & \\
\hline & Sample J723 & $(431)$ & & & & \\
\hline & Sample J724 & $(417)$ & & & & \\
\hline
\end{tabular}


Table A-1. Tank 241-C-110 Analytical Data: Cobalt

\begin{tabular}{|c|c|c|c|c|c|c|}
\hline Analyte $\because$ & $\begin{array}{l}\text { Laboratory } \\
\text { Sample } \\
\text { Identification }\end{array}$ & $\begin{array}{c}\text { Analytical } \\
\text { Data } \\
\text { Result }\end{array}$ & $\begin{array}{c}\text { Range } \\
\text { of } \\
\text { Values }\end{array}$ & $\begin{array}{l}\text { Weighted } \\
\text { Meant } \\
\text { Standard } \\
\text { Error }\end{array}$ & $\begin{array}{c}\text { Evaluated } \\
\text { Data } \\
\text { Result }\end{array}$ & $\begin{array}{l}\text { Projected } \\
\text { Inventory }\end{array}$ \\
\hline Metal (Liquid) & & $\mu \mathrm{g} / \mathrm{mL}$ & $\mu \mathrm{g} / \mathrm{mL}$ & $\mu \mathrm{g} / \mathrm{mL}$ & $\mu \mathrm{g} / \mathrm{mL}$ & $\mathrm{kg}$ \\
\hline \multirow[t]{4}{*}{ ICP.d.Co } & Sample J783 & $(0.500)$ & \multirow{4}{*}{$\begin{array}{l}0.500 \\
\text { to } \\
1.01\end{array}$} & \multirow[t]{4}{*}{---} & \multirow[t]{4}{*}{0.649} & \multirow[t]{4}{*}{0.0172} \\
\hline & Sample J778 & $(0.510)$ & & & & \\
\hline & Sample J775 & $(0.576)$ & & & & \\
\hline & Sample J800 & $(1.01)$ & & & & \\
\hline Metal (Solid) & & $\mu \mathrm{g} / \mathrm{g}$ & $\mu \mathrm{g} / \mathrm{g}$ & $\mu \mathrm{g} / \mathrm{g}$ & $\mu \mathrm{g} / \mathrm{g}$ & $\mathrm{kg}$ \\
\hline \multirow[t]{5}{*}{ ICP.w.Co } & Sample J691 & $(1.02)$ & \multirow{5}{*}{$\begin{array}{l}0.814 \\
\text { to } \\
2.42\end{array}$} & \multirow[t]{5}{*}{1.18} & \multirow[t]{5}{*}{$\cdots$} & \multirow[t]{19}{*}{6.77} \\
\hline & Sample J704 & $(2.42)$ & & & & \\
\hline & Sample $\mathbf{J 7 0 7}$ & $(0.814)$ & & & & \\
\hline & Sample J711 & $(1.02)$ & & & & \\
\hline & Sample J712 & $(1.02)$ & & & & \\
\hline \multirow{4}{*}{$\begin{array}{l}\text { ICP.a.Co } \\
\text { Segment } \\
\text { Sample }\end{array}$} & Sample J647 & $(1.86)$ & \multirow{4}{*}{$\begin{array}{c}1.59 \\
\text { to } \\
1.92\end{array}$} & \multirow[t]{4}{*}{---} & \multirow[t]{4}{*}{--} & \\
\hline & Sample J649 & $(1.59)$ & & & & \\
\hline & Sample J658 & $(1.92)$ & & & & \\
\hline & Sample J656 & $(1.02)$ & & & & \\
\hline \multirow{5}{*}{$\begin{array}{l}\text { ICP.a.Co } \\
\text { Core } \\
\text { Sample }\end{array}$} & Sample J666 & $(2.51)$ & \multirow{5}{*}{$\begin{array}{l}2.25 \\
\text { to } \\
2.97\end{array}$} & \multirow{5}{*}{0.264} & \multirow[t]{5}{*}{--} & \\
\hline & Sample J667 & $(2.80)$ & & & & \\
\hline & Sample $J 672$ & 2.97 & & & & \\
\hline & Sample J680 & 2.25 & & & & \\
\hline & Sample J683 & 2.64 & & & & \\
\hline \multirow[t]{5}{*}{ ICP.f.Co } & Sample J715 & $(5.08)$ & \multirow{5}{*}{$\begin{array}{c}5.00 \\
\text { to } \\
8.93\end{array}$} & \multirow[t]{5}{*}{6.59} & \multirow[t]{5}{*}{--} & \\
\hline & Sample J716 & $(5.07)$ & & & & \\
\hline & Sample J719 & $(8.93)$ & & & & \\
\hline & Sample $\mathrm{J723}$ & $(5.00)$ & & & & \\
\hline & Sample $\mathbf{J 7 2 4}$ & $(6.52)$ & & & & \\
\hline
\end{tabular}


WHC-SD-WM-ER-367 REV O

Table A-1. Tank 241-C-110 Analytical Data: Copper

\begin{tabular}{|c|c|c|c|c|c|c|}
\hline Analyte & $\begin{array}{l}\text { Laboratory } \\
\text { Sample. } \\
\text { Identification }\end{array}$ & $\begin{array}{c}\text { Analytical } \\
\text { Data } \\
\text { Result }\end{array}$ & $\begin{array}{c}\text { Range } \\
\text { of } \\
\text { Values }\end{array}$ & $\begin{array}{c}\text { Weighted } \\
\text { Mean/ } \\
\text { Standard } \\
\text { Error }\end{array}$ & $\begin{array}{c}\text { Evaluated } \\
\text { Data } \\
\text { Result }\end{array}$ & $\begin{array}{l}\text { Projected } \\
\text { Inventory }\end{array}$ \\
\hline Metal (Liquid) & & $\mu \mathrm{g} / \mathrm{mL}$ & $\mu \mathrm{g} / \mathrm{mL}$ & $\mu \mathrm{g} / \mathrm{mL}$ & $\mu \mathrm{g} / \mathrm{mL}$ & $\mathrm{kg}$ \\
\hline \multirow[t]{4}{*}{ ICP.d.Cu } & Sample $\mathbf{1 7 8 3}$ & $(0.266)$ & \multirow{4}{*}{$\begin{array}{c}0.266 \\
\text { to } \\
4.18\end{array}$} & \multirow[t]{4}{*}{---} & \multirow[t]{4}{*}{1.76} & \multirow[t]{4}{*}{0.0466} \\
\hline & Sample J778 & $(4.18)$ & & & & \\
\hline & Sample J775 & $(1.42)$ & & & & \\
\hline & Sample 1800 & $(1.10)$ & & & & \\
\hline Metal (Solid) & & $\mu \mathrm{g} / \mathrm{g}$ & $\mu \mathrm{g} / \mathrm{g}$ & $\mu \mathrm{g} / \mathrm{g}$ & $\mu g / g$ & $\mathrm{~kg}$ \\
\hline \multirow[t]{5}{*}{ ICP.w.Cu } & Sample J691 & $(8.35)$ & \multirow{5}{*}{$\begin{array}{c}0.548 \\
\text { to } \\
8.35\end{array}$} & \multirow[t]{5}{*}{2.11} & \multirow[t]{5}{*}{---} & \multirow[t]{19}{*}{102} \\
\hline & Sample J704 & $(1.21)$ & & & & \\
\hline & Sample J707 & $(0.954)$ & & & & \\
\hline & Sample J711 & $(0.626)$ & & & & \\
\hline & Sample J712 & $(0.548)$ & & & & \\
\hline \multirow{4}{*}{$\begin{array}{l}\text { ICP.a.Cu } \\
\text { Segment } \\
\text { Sample }\end{array}$} & Sample J647 & $(27.4)$ & \multirow{4}{*}{$\begin{array}{l}20.6 \\
\text { to } \\
27.4\end{array}$} & \multirow[t]{4}{*}{$\cdots$} & \multirow[t]{4}{*}{$\cdots$} & \\
\hline & Sample J649 & $(24.7)$ & & & & \\
\hline & Sample J658 & $(21.3)$ & & & & \\
\hline & Sample $J 656$ & $(20.6)$ & & & & \\
\hline \multirow{5}{*}{$\begin{array}{r}\text { ICP.a.Cu } \\
\text { Core } \\
\text { Sample }\end{array}$} & Sample J666 & $(43.4)$ & \multirow{5}{*}{$\begin{array}{l}19.2 \\
\text { to } \\
43.4\end{array}$} & \multirow[t]{5}{*}{30.0} & \multirow[t]{5}{*}{--} & \\
\hline & Sample J667 & $(43.0)$ & & & & \\
\hline & Sample J672 & $(26.3)$ & & & & \\
\hline & Sample J680 & $(19.2)$ & & & & \\
\hline & Sample J683 & $(21.7)$ & & & & \\
\hline \multirow[t]{5}{*}{ ICP.f.Cu } & Sample J715 & 55.2 & \multirow{5}{*}{$\begin{array}{c}<47.1 \\
\text { to } \\
182\end{array}$} & \multirow[t]{5}{*}{98.9} & \multirow[t]{5}{*}{--} & \\
\hline & Sample J716 & 73.9 & & & & \\
\hline & Sample J719 & 182 & & & & \\
\hline & Sample $\mathrm{J723}$ & 52.7 & & & & \\
\hline & Sample J724 & $<47.1^{*}$ & & & & \\
\hline
\end{tabular}

- Blank Contamination 
Table A-1. Tank 241-C-110 Analytical Data: Iron

\begin{tabular}{|c|c|c|c|c|c|c|}
\hline Analyte & $\begin{array}{c}\text { Laboratory } \\
\text { Sample } \\
\text { Identification }\end{array}$ & $\begin{array}{c}\text { Analytical } \\
\text { Data } \\
\text { Result }\end{array}$ & $\begin{array}{c}\text { Range } \\
\text { of } \\
\text { Values }\end{array}$ & $\begin{array}{c}\text { Weighted } \\
\text { Mean/ } \\
\text { Standard } \\
\text { Error }\end{array}$ & $\begin{array}{c}\text { Evaluated } \\
\text { Data } \\
\text { Result }\end{array}$ & $\begin{array}{l}\text { Projected } \\
\text { Inventory }\end{array}$ \\
\hline Metal (Liquid) & & $\mu \mathrm{g} / \mathrm{mL}$ & $\mu \mathrm{g} / \mathrm{mL}$ & $\mu \mathrm{g} / \mathrm{mL}$ & $\mu \mathrm{g} / \mathrm{mL}$ & $\mathrm{kg}$ \\
\hline \multirow[t]{4}{*}{ ICP.d.Fe } & Sample $\mathbf{J 7 8 3}$ & $(<0.750)$ & \multirow{4}{*}{$\begin{array}{c}<0.750 \\
\text { to } \\
140\end{array}$} & \multirow[t]{4}{*}{--} & \multirow[t]{4}{*}{47.3} & \multirow[t]{4}{*}{1.25} \\
\hline & Sample J778 & $(31.4)$ & & & & \\
\hline & Sample J775 & $(17.1)$ & & & & \\
\hline & Sample $\mathbf{J 8 0 0}$ & $(140)$ & & & & \\
\hline Metal (Solid) & . & $\mu \mathrm{g} / \mathrm{g}$ & . $\mu g / g$ & $\mu \mathrm{g} / \mathrm{g}$ & $\mu g / g$ & $\mathrm{~kg}$ \\
\hline \multirow[t]{5}{*}{ ICP.w.Fe } & Sample J691 & $(2,100)$ & \multirow{5}{*}{$\begin{array}{c}39.5 \\
\text { to } \\
2,100\end{array}$} & \multirow[t]{5}{*}{584} & \multirow[t]{5}{*}{---} & \multirow[t]{19}{*}{11,300} \\
\hline & Sample J704 & $(39.5)$ & & & & \\
\hline & Sample J707 & $(420)$ & & & & \\
\hline & Sample J711 & $(251)$ & & & & \\
\hline & Sample $\mathbf{J} 712$ & $(275)$ & & & & \\
\hline \multirow{4}{*}{$\begin{array}{l}\text { ICP.a.Fe } \\
\text { Segment } \\
\text { Sample }\end{array}$} & Sample J647 & $(10,100)$ & \multirow{4}{*}{$\begin{array}{c}8,990 \\
\text { to } \\
10,100\end{array}$} & \multirow[t]{4}{*}{--} & \multirow[t]{4}{*}{--} & \\
\hline & Sample J649 & $(10,100)$ & & & & \\
\hline & Sample J658 & $(9,160)$ & & & & \\
\hline & Sample J656 & $(8,990)$ & & & & \\
\hline \multirow{5}{*}{$\begin{array}{c}\text { ICP.a.Fe } \\
\text { Core } \\
\text { Sample }\end{array}$} & Sample J666 & $(12,000)$ & \multirow{5}{*}{$\begin{array}{c}9,400 \\
\text { to } \\
12,300\end{array}$} & \multirow[t]{5}{*}{11,000} & \multirow[t]{5}{*}{--} & \\
\hline & Sample J667 & $(12,300)$ & & & & \\
\hline & Sample J672 & $(11,400)$ & & & & \\
\hline & Sample J680 & $(9,400)$ & & & & \\
\hline & Sample J683 & $(9,660)$ & & & & \\
\hline \multirow[t]{5}{*}{ ICP.f.Fe } & Sample J715 & $(11,600)$ & \multirow{5}{*}{$\begin{array}{c}9,100 \\
\text { to } \\
11,600\end{array}$} & \multirow[t]{5}{*}{10,700} & \multirow[t]{5}{*}{---} & \\
\hline & Sample J716 & $(11,600)$ & & & & \\
\hline & Sample $J 719$ & $(11,300)$ & & & & \\
\hline & Sample J723 & $(9,540)$ & & & & \\
\hline & Sample $J 724$ & $(9,100)$ & & & & \\
\hline
\end{tabular}


Table A-1. Tank 241-C-110 Analytical Data: Lanthanum

\begin{tabular}{|c|c|c|c|c|c|c|}
\hline Analyte & $\begin{array}{l}\text { Laboratory } \\
\text { Sample } \\
\text { Identification }\end{array}$ & $\begin{array}{c}\text { Analytical } \\
\text { Data } \\
\text { Result }\end{array}$ & $\begin{array}{c}\text { Range } \\
\text { of } \\
\text { Values }\end{array}$ & $\begin{array}{c}\text { Weighted } \\
\text { Mean/ } \\
\text { Standard } \\
\text { Error }\end{array}$ & $\begin{array}{c}\text { Evaluated } \\
\text { Data } \\
\text { Result }\end{array}$ & $\begin{array}{l}\text { Projected } \\
\text { Inventory }\end{array}$ \\
\hline Metal (Liquid) & & $\mu \mathrm{g} / \mathrm{mL}$ & $\mu \mathrm{g} / \mathrm{mL}$ & $\mu \mathrm{g} / \mathrm{mL}$ & $\mu \mathrm{g} / \mathrm{mL}$ & $\mathrm{kg}$ \\
\hline \multirow[t]{4}{*}{ ICP.d.La } & Sample J783 & $(0.800)$ & \multirow{4}{*}{$\begin{array}{c}0.800 \\
\text { to } \\
1.62\end{array}$} & \multirow[t]{4}{*}{---} & \multirow[t]{4}{*}{1.01} & \multirow[t]{4}{*}{0.0268} \\
\hline & Sample $J 778$ & $(0.816)$ & & & & \\
\hline & Sample $J 775$ & $(0.816)$ & & & & \\
\hline & Sample J800 & $(1.62)$ & & & & \\
\hline Metal (Solid) & & $\mu g / g$ & $\mu \mathrm{g} / \mathrm{g}$ & $\mu \mathrm{g} / \mathrm{g}$ & $\mu \mathrm{g} / \mathrm{g}$ & $\mathrm{kg}$ \\
\hline \multirow[t]{5}{*}{ ICP.W.La } & Sample J691 & $(1.63)$ & \multirow{5}{*}{$\begin{array}{l}1.43 \\
\text { to } \\
4.23\end{array}$} & \multirow{5}{*}{0.814} & \multirow[t]{5}{*}{---} & \multirow[t]{19}{*}{2.05} \\
\hline & Sample J704 & $(4.23)$ & & & & \\
\hline & Sample J707 & $(1.43)$ & & & & \\
\hline & Sample $J 711$ & $(1.63)$ & & & & \\
\hline & Sample J712 & $(1.63)$ & & & & \\
\hline \multirow{4}{*}{$\begin{array}{l}\text { ICP.a.La } \\
\text { Segment } \\
\text { Sample }\end{array}$} & Sample J647 & $<1.40$ & \multirow[t]{4}{*}{ N/A } & \multirow[t]{4}{*}{$\cdots$} & \multirow[t]{4}{*}{---} & \\
\hline & Sample J649 & $<1.40$ & & & & \\
\hline & Sample J658 & $<1.60$ & & & & \\
\hline & Sample J656 & $<1.60$ & & & & \\
\hline \multirow{5}{*}{$\begin{array}{r}\text { Core } \\
\text { Sample }\end{array}$} & Sample J666 & $<1.40$ & \multirow[t]{5}{*}{ N/A } & \multirow[t]{5}{*}{--} & \multirow[t]{5}{*}{$<1.60$} & \\
\hline & Sample J667 & $<1.40$ & & & & \\
\hline & Sample J672 & $<1.60$ & & & & \\
\hline & Sample J680 & $<1.40$ & & & & \\
\hline & Sample J683 & $<1.40$ & & & & \\
\hline \multirow[t]{5}{*}{ ICP.f.La } & Sample J715 & $<8.00$ & \multirow[t]{5}{*}{ N/A } & \multirow[t]{5}{*}{--} & \multirow[t]{5}{*}{$<8.00$} & \\
\hline & Sample J716 & $<8.00$ & & & & \\
\hline & Sample J719 & $<8.00$ & & & & \\
\hline & Sample J723 & $<8.00$ & & & & \\
\hline & Sample J724 & $<8.00$ & & & & \\
\hline
\end{tabular}


Table A-1. Tank 241-C-110 Analytical Data: Lead

\begin{tabular}{|c|c|c|c|c|c|c|}
\hline $\begin{array}{l}\text { Analyte } \\
.\end{array}$ & $\begin{array}{l}\text { Laboratory } \\
\text { Sample } \\
\text { Identification }\end{array}$ & $\begin{array}{l}\text { Analytical } \\
\text { Data } \\
\text { Result }\end{array}$ & $\begin{array}{c}\text { Range } \\
\text { of } \\
\text { Values }\end{array}$ & $\begin{array}{c}\text { Weighted } \\
\text { Mean/ } \\
\text { Standard } \\
\text { Error }\end{array}$ & $\begin{array}{c}\text { Evaluated } \\
\text { Data } \\
\text { Result }\end{array}$ & $\begin{array}{l}\text { Projected } \\
\text { Inventory }\end{array}$ \\
\hline Metal (Liquid) & & $\mu \mathrm{g} / \mathrm{mL}$ & $\mu \mathrm{g} / \mathrm{mL}$ & $\mu \mathrm{g} / \mathrm{mL}$ & $\mu \mathrm{g} / \mathrm{mL}$ & kg \\
\hline \multirow[t]{4}{*}{ ICP.d.Pb } & Sample J783 & $(3.55)$ & \multirow{4}{*}{$\begin{array}{l}3.55 \\
\text { to } \\
7.17\end{array}$} & \multirow[t]{4}{*}{--- } & \multirow[t]{4}{*}{5.37} & \multirow[t]{5}{*}{0.142} \\
\hline & Sample J778 & $(7.14)$ & & & & \\
\hline & Sample J775 & $(3.62)$ & & & & \\
\hline & Sample J800 & $(7.17)$ & & & & \\
\hline TCLP.ICP.Pb & Sample $J 723$ & $(1.23)$ & N/A & & 1.23 & \\
\hline Metal (Solid) & & $\mu \mathrm{g} / \mathrm{g}$ & $\mu g / g$ & $\mu \mathrm{g} / \mathrm{g}$ & $\mu g / g$ & $\mathrm{~kg}$ \\
\hline \multirow[t]{5}{*}{ ICP.w.Pb } & Sample J691 & $(61.3)$ & \multirow{5}{*}{$\begin{array}{l}6.31 \\
\text { to } \\
61.3\end{array}$} & \multirow[t]{5}{*}{17.6} & \multirow[t]{5}{*}{$\cdots$} & \multirow[t]{19}{*}{265} \\
\hline & Sample J704 & $(17.1)$ & & & & \\
\hline & Sample J707 & $(6.31)$ & & & & \\
\hline & Sample J711 & $(7.21)$ & & & & \\
\hline & Sample J712 & $(7.22)$ & & & & \\
\hline \multirow{4}{*}{$\begin{array}{l}\text { ICP.a.Pb } \\
\text { Segment } \\
\text { Sample }\end{array}$} & Sample J647 & $(134)$ & \multirow{4}{*}{$\begin{array}{l}68.0 \\
\text { to } \\
134\end{array}$} & \multirow[t]{4}{*}{---} & \multirow[t]{4}{*}{--} & \\
\hline & Sample J649 & $(132)$ & & & & \\
\hline & Sample J658 & $(77.2)$ & & & & \\
\hline & Sample J656 & $(68.0)$ & & & & \\
\hline \multirow{5}{*}{$\begin{array}{r}\text { ICP.a.Pb } \\
\text { Core } \\
\text { Sample }\end{array}$} & Sample J666 & $(424)$ & \multirow{5}{*}{$\begin{array}{l}103 \\
\text { to } \\
426\end{array}$} & \multirow[t]{5}{*}{232} & \multirow[t]{5}{*}{--} & \\
\hline & Sample J667 & $(426)$ & & & & \\
\hline & Sample J672 & $(167)$ & & & & \\
\hline & Sample J680 & $(103)$ & & & & \\
\hline & Sample $\mathrm{J} 683$ & $(107)$ & & & & \\
\hline \multirow[t]{5}{*}{ ICP.f.Pb } & Sample J715 & (449) & \multirow{5}{*}{$\begin{array}{l}114 \\
\text { to } \\
449\end{array}$} & \multirow[t]{5}{*}{258} & \multirow[t]{5}{*}{$\cdots$} & \\
\hline & Sample J716 & $(434)$ & & & & \\
\hline & Sample J719 & $(212)$ & & & & \\
\hline & Sample J723 & $(114)$ & & & & \\
\hline & Sample J724 & $(127)$ & & & & \\
\hline
\end{tabular}


WHC-SD-WM-ER-367 REV O

Table A-1. Tank 241-C-110 Analytical Data: Magnesium

\begin{tabular}{|c|c|c|c|c|c|c|}
\hline Analyte & $\begin{array}{l}\text { Laboratory } \\
\text { Sample } \\
\text { Identification }\end{array}$ & $\begin{array}{c}\text { Analytical } \\
\text { Data } \\
\text { Result }\end{array}$ & $\begin{array}{c}\text { Range } \\
\text { of } \\
\text { Values }\end{array}$ & $\begin{array}{l}\text { Weighted } \\
\text { Mean/ } \\
\text { Standard } \\
\text { Error }\end{array}$ & $\begin{array}{c}\text { Evaluated } \\
\text { Data } \\
\text { Result }\end{array}$ & $\begin{array}{l}\text { Projected } \\
\text { Inventory }\end{array}$ \\
\hline Metal (Liquid) & & $\mu \mathrm{g} / \mathrm{mL}$ & $\mu \mathrm{g} / \mathrm{mL}$ & $\mu \mathrm{g} / \mathrm{mL}$ & $\mu \mathrm{g} / \mathrm{mL}$ & $\mathrm{kg}$ \\
\hline \multirow[t]{4}{*}{ ICP.d.Mg } & Sample J783 & $(0.427)$ & \multirow{4}{*}{$\begin{array}{c}0.427 \\
\text { to } \\
3.02\end{array}$} & \multirow[t]{4}{*}{--} & \multirow[t]{4}{*}{1.39} & \multirow[t]{4}{*}{0.0368} \\
\hline & Sample J778 & $(1.22)$ & & & & \\
\hline & Sample J775 & $(0.903)$ & & & & \\
\hline & Sample J800 & $(3.02)$ & & & & \\
\hline Metal (Solid) & & $\mu \mathrm{g} / \mathrm{g}$ & $\mu \mathrm{g} / \mathrm{g}$ & $\mu \mathrm{g} / \mathrm{g}$ & $\mu \mathrm{g} / \mathrm{g}$ & $\mathrm{kg}$ \\
\hline \multirow[t]{5}{*}{ ICP.w.Mg } & Sample J691 & $(19.4)$ & \multirow{5}{*}{$\begin{array}{l}5.49 \\
\text { to } \\
28.2\end{array}$} & \multirow[t]{5}{*}{16.5} & \multirow[t]{5}{*}{--} & \multirow[t]{19}{*}{157} \\
\hline & Sample J704 & 12.0 & & & & \\
\hline & Sample J707 & $(28.2)$ & & & & \\
\hline & Sample J711 & 5.74 & & & & \\
\hline & Sample J712 & 5.49 & & & & \\
\hline \multirow{4}{*}{$\begin{array}{l}\text { ICP.a.Mg } \\
\text { Segment } \\
\text { Sample }\end{array}$} & Sample J647 & 150 & \multirow{4}{*}{$\begin{array}{c}121 \\
\text { to } \\
<256\end{array}$} & \multirow[t]{4}{*}{--- } & \multirow[t]{4}{*}{--} & \\
\hline & Sample J649 & 243 & & & & \\
\hline & Sample J658 & $<256^{*}$ & & & & \\
\hline & Sample J656 & $(121)$ & & & & \\
\hline \multirow{5}{*}{$\begin{array}{r}\text { ICP.a.Mg } \\
\text { Core } \\
\text { Sample }\end{array}$} & Sample J666 & $(198)$ & \multirow{5}{*}{$\begin{array}{l}114 \\
\text { to } \\
198\end{array}$} & \multirow{5}{*}{20.5} & \multirow[t]{5}{*}{$--\cdot$} & \\
\hline & Sample J667 & $(170)$ & & & & \\
\hline & Sample J672 & $(148)$ & & & & \\
\hline & Sample J680 & $(114)$ & & & & \\
\hline & Sample J683 & $(115)$ & & & & \\
\hline \multirow[t]{5}{*}{ ICP.f.Mg } & Sample J715 & $(166)$ & \multirow{5}{*}{$\begin{array}{l}117 \\
\text { to } \\
167\end{array}$} & \multirow[t]{5}{*}{153} & \multirow[t]{5}{*}{.-} & \\
\hline & Sample J716 & $(145)$ & & & & \\
\hline & Sample J719 & $(161)$ & & & & \\
\hline & Sample J723 & $(117)$ & & & & \\
\hline & Sample J724 & $(167)$ & & & & \\
\hline
\end{tabular}

- Blank Contamination 
Table A-1. Tank 241-C-110 Analytical Data: Manganese

\begin{tabular}{|c|c|c|c|c|c|c|}
\hline Analyte : & $\begin{array}{c}\text { Laboratory } \\
\text { Sample } \\
\text { Identification }\end{array}$ & $\begin{array}{c}\text { Analytical } \\
\text { Data } \\
\text {-Result }\end{array}$ & $\begin{array}{l}\text { Range } \\
\text { of } \\
\text { Values }\end{array}$ & $\begin{array}{c}\text { Weighted } \\
\text { Mean/ } \\
\text { Standard } \\
\text { Error }\end{array}$ & $\begin{array}{c}\text { Evaluated } \\
\text { Data } \\
\text { Result }\end{array}$ & $\begin{array}{l}\text { Projected } \\
\text { Inventory }\end{array}$ \\
\hline Metal (Liquid) & & $\mu \mathrm{g} / \mathrm{mL}$ & $\mu g / \mathrm{mL}$ & $\mu \mathrm{g} / \mathrm{mL}$ & $\mu g / m L$ & $\mathrm{~kg}$ \\
\hline \multirow[t]{4}{*}{ ICP.d.Mn } & Sample J783 & $(0.150)$ & \multirow{4}{*}{$\begin{array}{c}0.150 \\
\text { to } \\
0.533\end{array}$} & \multirow[t]{4}{*}{$\cdots$} & \multirow[t]{4}{*}{0.287} & \multirow[t]{4}{*}{0.00761} \\
\hline & Sample J778 & $(0.228)$ & & & & \\
\hline & Sample $J 775$ & $(0.238)$ & & & & \\
\hline & Sample J800 & $(0.533)$ & & & & \\
\hline Metal (Solid) & & $\mu \mathrm{g} / \mathrm{g}$ & $\mu \mathrm{g} / \mathrm{g}$ & $\mu \mathrm{g} / \mathrm{g}$ & $\mu \mathrm{g} / \mathrm{g}$ & $\mathrm{kg}$ \\
\hline \multirow[t]{5}{*}{ ICP.w.Mn } & Sample J691 & $(6.93)$ & \multirow{5}{*}{$\begin{array}{c}0.604 \\
\text { to } \\
6.93\end{array}$} & \multirow[t]{2}{*}{1.99} & \multirow[t]{5}{*}{--} & \multirow[t]{19}{*}{57.8} \\
\hline & Sample J704 & $(0.604)$ & & & & \\
\hline & Sample J707 & $(1.52)$ & & 1.29 & & \\
\hline & Sample J711 & $(0.675)$ & & & & \\
\hline & Sample J712 & $(0.661)$ & & & & \\
\hline \multirow{4}{*}{$\begin{array}{l}\text { ICP.a.Mn } \\
\text { Segment } \\
\text { Sample }\end{array}$} & Sample J647 & $(32.7)$ & \multirow{4}{*}{$\begin{array}{c}29.5 \\
\text { to } \\
33.9\end{array}$} & \multirow[t]{4}{*}{---} & \multirow[t]{4}{*}{--} & \\
\hline & Sample J649 & $(33.9)$ & & & & \\
\hline & Sample J658 & 32.8 & & & & \\
\hline & Sample J656 & $(29.5)$ & & & & \\
\hline \multirow{5}{*}{$\begin{array}{r}\text { ICP.a.Mn } \\
\text { Core } \\
\text { Sample }\end{array}$} & Sample J666 & $(41.1)$ & \multirow{5}{*}{$\begin{array}{c}28.3 \\
\text { to } \\
41.6\end{array}$} & \multirow[t]{5}{*}{35.8} & \multirow[t]{5}{*}{--} & \\
\hline & Sample J667 & $(41.6)$ & & & & \\
\hline & Sample J672 & $(37.0)$ & & & & \\
\hline & Sample J680 & $(28.3)$ & & & & \\
\hline & Sample J683 & $(29.6)$ & & & & \\
\hline \multirow[t]{5}{*}{ ICP.f.Mn } & Sample J715 & 52.1 & \multirow{5}{*}{$\begin{array}{c}31.9 \\
\text { to } \\
72.8\end{array}$} & \multirow[t]{5}{*}{56.3} & \multirow[t]{5}{*}{--} & \\
\hline & Sample J716 & 48.3 & & & & \\
\hline & Sample $\mathbf{J 7 1 9}$ & $(72.8)$ & & & & \\
\hline & Sample J723 & $(31.9)$ & & & & \\
\hline & Sample J724 & $(59.8)$ & & & & \\
\hline
\end{tabular}


Table A-1. Tank 241-C-110 Analytical Data: Mercury

\begin{tabular}{|c|c|c|c|c|c|c|}
\hline $\begin{array}{ll}\text { Analyte } \\
\ddots\end{array}$ & $\begin{array}{l}\text { Laboratory } \\
\text { Sample } \\
\text { Identification }\end{array}$ & $\begin{array}{l}\text { Analytical } \\
\therefore \text { Data } . . \\
\therefore \text { Result }\end{array}$ & $\begin{array}{l}\text { Range } \\
\text { Vaf of } \\
\text { Values }\end{array}$ & $\begin{array}{c}\text { Weighted } \\
\text { Mean/ } \\
\text { Standard } \\
\text { Error }\end{array}$ & $\begin{array}{c}\text { Evaluated } \\
\text { Data -. } \\
\text { Result }\end{array}$ & $\begin{array}{l}\text { Projected } \\
\text { Inventory }\end{array}$ \\
\hline Metal (Liquid) & & $\mu \mathrm{g} / \mathrm{mL}$ & $\mu \mathrm{g} / \mathrm{mL}$ & $\mu \mathrm{g} / \mathrm{mL}$ & $\mu \mathrm{g} / \mathrm{mL}$ & $\mathrm{kg}$ \\
\hline CVAA.Hg & Sample J800 & 0.106 & N/A & $\cdots$ & 0.106 & \multirow[t]{2}{*}{0.00281} \\
\hline TCLP.CVAA.Hg & Sample J723 & 0.111 & N/A & & 0.111 & \\
\hline Metal (Solid) & & $\mu \mathrm{g} / \mathrm{g}$ & $\mu \mathrm{g} / \mathrm{g}$ & $\mu \mathrm{g} / \mathrm{g}$ & $\mu g / g$ & $\mathrm{~kg}$ \\
\hline \multirow[t]{5}{*}{ CVAA.Hg } & Sample J651 & 0.449 & \multirow{5}{*}{$\begin{array}{c}0.327 \\
\text { to } \\
0.619\end{array}$} & \multirow[t]{5}{*}{0.450} & \multirow[t]{5}{*}{--} & \multirow[t]{5}{*}{0.462} \\
\hline & Sample J653 & $(0.619)$ & & & & \\
\hline & Sample J657 & 0.482 & & & & \\
\hline & Sample J662 & 0.327 & & & & \\
\hline & Sample J663 & 0.338 & & & & \\
\hline
\end{tabular}


WHC-SD-WM-ER-367 REV O

Table A-1. Tank 241-C-110 Analytical Data: Nickel

\begin{tabular}{|c|c|c|c|c|c|c|}
\hline Analyte & $\begin{array}{l}\text { Laboratory } \\
\text { Sample } \\
\text { Identification }\end{array}$ & $\begin{array}{c}\text { Analytical } \\
\text { Data } \\
\text { Result. }\end{array}$ & $\begin{array}{l}\text { Range } \\
\text { of } \\
\text { Values }\end{array}$ & $\begin{array}{l}\text { Weighted } \\
\text { Mean/ } \\
\text { Standard } \\
\text { Error }\end{array}$ & $\begin{array}{c}\text { Evaluated } \\
\text { Data } \\
\text { Result }\end{array}$ & $\begin{array}{l}\text { Projected } \\
\text { Inventory }\end{array}$ \\
\hline Metal (Liquid) & & $\mu \mathrm{g} / \mathrm{mL}$ & $\mu \mathrm{g} / \mathrm{mL}$ & $\mu \mathrm{g} / \mathrm{mL}$ & $\mu \mathrm{g} / \mathrm{mL}$ & $\mathrm{kg}$ \\
\hline \multirow[t]{4}{*}{ ICP.d.Ni } & Sample J783 & $(0.700)$ & \multirow{4}{*}{$\begin{array}{l}0.700 \\
\text { to } \\
1.80\end{array}$} & \multirow[t]{4}{*}{---} & \multirow[t]{4}{*}{1.16} & \multirow[t]{4}{*}{0.0307} \\
\hline & Sample $\mathbf{J 7 7 8}$ & $(1.80)$ & & & & \\
\hline & Sample J775 & $(0.714)$ & & & & \\
\hline & Sample J800 & $(1.41)$ & & & & \\
\hline Metal (Solid) & & $\mu \mathrm{g} / \mathrm{g}$ & $\mu \mathrm{g} / \mathrm{g}$ & $\mu \mathrm{g} / \mathrm{g}$ & $\mu \mathrm{g} / \mathrm{g}$ & $\mathrm{kg}$ \\
\hline \multirow[t]{5}{*}{ ICP.w.Ni } & Sample J691 & $(6.21)$ & \multirow{5}{*}{$\begin{array}{l}1.42 \\
\text { to } \\
6.21\end{array}$} & \multirow[t]{5}{*}{2.76} & \multirow[t]{5}{*}{$\ldots$} & \multirow[t]{14}{*}{24.5} \\
\hline & Sample J704 & $(3.63)$ & & & & \\
\hline & Sample $\mathrm{J} 707$ & $(1.95)$ & & & & \\
\hline & Sample J711 & $(1.42)$ & & & & \\
\hline & Sample J712 & $(1.42)$ & & & & \\
\hline \multirow{4}{*}{$\begin{array}{l}\text { ICP.a.Ni } \\
\text { Segment } \\
\text { Sample }\end{array}$} & Sample J647 & $(21.8)$ & \multirow{4}{*}{$\begin{array}{l}16.0 \\
\text { to } \\
21.8\end{array}$} & \multirow[t]{4}{*}{--} & \multirow[t]{4}{*}{--} & \\
\hline & Sample J649 & $(18.8)$ & & & & \\
\hline & Sample J658 & 16.0 & & & & \\
\hline & Sample J656 & $(16.1)$ & & & & \\
\hline \multirow{5}{*}{$\begin{array}{r}\text { ICP.a.Ni } \\
\text { Core } \\
\text { Sample }\end{array}$} & Sample J666 & $(25.9)$ & \multirow{5}{*}{$\begin{array}{l}10.2 \\
\text { to } \\
25.9\end{array}$} & \multirow[t]{5}{*}{23.9} & \multirow[t]{5}{*}{---} & \\
\hline & Sample J667 & $(25.2)$ & & & & \\
\hline & Sample J672 & $(22.8)$ & & & & \\
\hline & Sample J680 & 10.2 & & & & \\
\hline & Sample J683 & 36.8 & & & & \\
\hline
\end{tabular}


Table A-1. Tank 241-C-110 Analytical Data: Phosphorus

\begin{tabular}{|c|c|c|c|c|c|c|}
\hline Analyte & $\begin{array}{l}\text { Laboratory } \\
\text { Sample } \\
\text { Identification }\end{array}$ & $\begin{array}{c}\text { Analytical } \\
\text { Data } \\
\text { Result }\end{array}$ & $\begin{array}{c}\text { Range } \\
\text { of } \\
\text { Values }\end{array}$ & $\begin{array}{c}\text { Weighted } \\
\text { Mean/ } \\
\text { Standard } \\
\text { Error }\end{array}$ & $\begin{array}{c}\text { Evaluated } \\
\text { Data } \\
\text { Result }\end{array}$ & $\begin{array}{l}\text { Projected } \\
\text { Inventory }\end{array}$ \\
\hline Metal (Liquid) & & $\mu \mathrm{g} / \mathrm{mL}$ & $\mu \mathrm{g} / \mathrm{mL}$ & $\mu \mathrm{g} / \mathrm{mL}$ & $\mu \mathrm{g} / \mathrm{mL}$ & $\mathrm{kg}$ \\
\hline \multirow[t]{4}{*}{ ICP.d.P } & Sample J783 & $(661)$ & \multirow{4}{*}{$\begin{array}{c}661 \\
\text { to } \\
3,110\end{array}$} & \multirow[t]{4}{*}{$\cdots$} & \multirow[t]{4}{*}{2,050} & \multirow[t]{4}{*}{54.3} \\
\hline & Sample J778 & $(2,750)$ & & & & \\
\hline & Sample $J 775$ & $(3,110)$ & & & & \\
\hline & Sample 1800 & $(1,660)$ & & & & \\
\hline Metal (Solid) & & $\mu \mathrm{g} / \mathrm{g}$ & $\mu \mathrm{g} / \mathrm{g}$ & $\mu \mathrm{g} / \mathrm{g}$ & $\mu \mathrm{g} / \mathrm{g}$ & $\mathrm{kg}$ \\
\hline \multirow[t]{5}{*}{ ICP.w.P } & Sample J691 & $(17,800)$ & \multirow{5}{*}{$\begin{array}{c}549 \\
\text { to } \\
17,800\end{array}$} & \multirow[t]{2}{*}{7,660} & \multirow[t]{5}{*}{---} & \multirow[t]{19}{*}{20,800} \\
\hline & Sample $J 704$ & $(549)$ & & & & \\
\hline & Sample J707 & $(6,190)$ & & \multirow[t]{3}{*}{3,000} & & \\
\hline & Sample J711 & $(5,720)$ & & & & \\
\hline & Sample $J 712$ & $(9,510)$ & & & & \\
\hline \multirow{4}{*}{$\begin{array}{l}\text { ICP.a.P } \\
\text { Segment } \\
\text { Sample }\end{array}$} & Sample J647 & $(18,000)$ & \multirow{4}{*}{$\begin{array}{c}18,000 \\
\text { to } \\
36,000\end{array}$} & \multirow[t]{4}{*}{--} & \multirow[t]{4}{*}{--} & \\
\hline & Sample J649 & $(18,400)$ & & & & \\
\hline & Sample J658 & $(31,400)$ & & & & \\
\hline & Sample J656 & $(36,000)$ & & & & \\
\hline \multirow{5}{*}{$\begin{array}{r}\text { ICP.a.P } \\
\text { Core } \\
\text { Sample }\end{array}$} & Sample J666 & $(21,400)$ & \multirow{5}{*}{$\begin{array}{c}16,100 \\
\text { to } \\
21,400\end{array}$} & \multirow[t]{5}{*}{18,500} & \multirow[t]{5}{*}{--} & \\
\hline & Sample J667 & $(21,300)$ & & & & \\
\hline & Sample J672 & $(16,100)$ & & & & \\
\hline & Sample J680 & $(18,500)$ & & & & \\
\hline & Sample J683 & $(17,700)$ & & & & \\
\hline \multirow[t]{5}{*}{ ICP.f.P } & Sample $J 715$ & $(21,100)$ & \multirow{5}{*}{$\begin{array}{c}18,600 \\
\text { to } \\
23,600\end{array}$} & \multirow[t]{5}{*}{20,300} & \multirow[t]{5}{*}{--} & \\
\hline & Sample J716 & $(23,600)$ & & & & \\
\hline & Sample $J 719$ & $(18,600)$ & & & & \\
\hline & Sample J723 & $(20,300)$ & & & & \\
\hline & Sample J724 & $(19,500)$ & & & & \\
\hline
\end{tabular}


WHC-SD-WM-ER-367 REV 0

Table A-1. Tank 241-C-110 Analytical Data: Potassium

\begin{tabular}{|c|c|c|c|c|c|c|}
\hline Analyte & $\begin{array}{l}\text { Laboratory } \\
\text { Sample } \\
\text { Identification }\end{array}$ & $\begin{array}{c}\text { Analytical } \\
\text { Data } \\
\text { Result }\end{array}$ & $\begin{array}{c}\text { Range } \\
\text { of } \\
\text { Values }\end{array}$ & $\begin{array}{c}\text { Weighted } \\
\text { Mean/ } \\
\text { Standard } \\
\text { Error }\end{array}$ & $\begin{array}{c}\text { Evaluated } \\
\text { Data } \\
\text { Result }\end{array}$ & $\begin{array}{l}\text { Projected } \\
\text { Inventory }\end{array}$ \\
\hline Metal (Liquid) & & $\mu \mathrm{g} / \mathrm{mL}$ & $\mu \mathrm{g} / \mathrm{mL}$ & $\mu \mathrm{g} / \mathrm{mL}$ & $\mu \mathrm{g} / \mathrm{mL}$ & $\mathrm{kg}$ \\
\hline \multirow[t]{4}{*}{ ICP.d.K } & Sample J783 & $(77.0)$ & \multirow{4}{*}{$\begin{array}{l}77.0 \\
\text { to } \\
986\end{array}$} & \multirow[t]{4}{*}{--} & \multirow[t]{4}{*}{436} & \multirow[t]{4}{*}{11.6} \\
\hline & Sample J778 & $(391)$ & & & & \\
\hline & Sample J775 & (986) & & & & \\
\hline & Sample 1800 & $(290)$ & & & & \\
\hline Metal (Solid) & & $\mu g / g$ & $\mu \mathrm{g} / \mathrm{g}$ & $\mu g / g$ & $\mu g / g$ & $\mathrm{~kg}$ \\
\hline \multirow[t]{5}{*}{ ICP.W.K } & Sample J691 & $(557)$ & \multirow{5}{*}{$\begin{array}{l}111 \\
\text { to } \\
557\end{array}$} & \multirow[t]{5}{*}{411} & \multirow[t]{5}{*}{--} & \multirow[t]{14}{*}{572} \\
\hline & Sample J704 & $(111)$ & & & & \\
\hline & Sample J707 & (375) & & & & \\
\hline & Sample J71 1 & $(510)$ & & & & \\
\hline & Sample $J 712$ & $(538)$ & & & & \\
\hline \multirow{4}{*}{$\begin{array}{l}\text { ICP.a.K } \\
\text { Segment } \\
\text { Sample }\end{array}$} & Sample J647 & $(412)$ & \multirow{4}{*}{$\begin{array}{l}412 \\
\text { to } \\
622\end{array}$} & \multirow[t]{4}{*}{$\cdots$} & \multirow[t]{4}{*}{--} & \\
\hline & Sample J649 & $(416)$ & & & & \\
\hline & Sample J658 & $(606)$ & & & & \\
\hline & Sample J656 & $(622)$ & & & & \\
\hline \multirow{5}{*}{$\begin{array}{c}\text { ICP.a.K } \\
\text { Core } \\
\text { Sample }\end{array}$} & Sample J666 & $(566)$ & \multirow{5}{*}{$\begin{array}{l}503 \\
\text { to } \\
624\end{array}$} & \multirow[t]{5}{*}{557} & \multirow[t]{5}{*}{--} & \\
\hline & Sample J667 & $(563)$ & & & & \\
\hline & Sample J672 & $(503)$ & & & & \\
\hline & Sample $J 680$ & $(581)$ & & & & \\
\hline & Sample J683 & $(624)$ & & & & \\
\hline
\end{tabular}


Table A-1. Tank 241-C-110 Analytical Data: Selenium

\begin{tabular}{|c|c|c|c|c|c|c|}
\hline Analyte & $\begin{array}{l}\text { Laboratory } \\
\text { Sample } \\
\text { Identification }\end{array}$ & $\begin{array}{c}\text { Analytical } \\
\text { Data } \\
\text { Result }\end{array}$ & $\begin{array}{c}\text { Range } \\
\text { of } \\
\text { Values }\end{array}$ & $\begin{array}{c}\text { Weighted } \\
\text { Mean/ } \\
\text { Standard } \\
\text { Error }\end{array}$ & $\begin{array}{c}\text { Evaluated } \\
\text { Data } \\
\text { Result }\end{array}$ & $\begin{array}{l}\text { Projected } \\
\text { Inventory }\end{array}$ \\
\hline Metal (Liquid) & & $\mu \mathrm{g} / \mathrm{mL}$ & $\mu \mathrm{g} / \mathrm{mL}$ & $\mu \mathrm{g} / \mathrm{mL}$ & $\mu \mathrm{g} / \mathrm{mL}$ & kg \\
\hline \multirow[t]{4}{*}{ ICP.d.Se } & Sample J783 & $(4.62)$ & \multirow{4}{*}{$\begin{array}{l}4.62 \\
\text { to } \\
79.7\end{array}$} & \multirow[t]{4}{*}{--- } & \multirow[t]{4}{*}{32.4} & \multirow[t]{7}{*}{0.859} \\
\hline & Sample 1778 & $(27.8)$ & & & & \\
\hline & Sample J775 & $(79.7)$ & & & & \\
\hline & Sample J800 & $(17.3)$ & & & & \\
\hline TCLP.ICP.Se & Sample J723 & $(5.35)$ & N/A & & 5.35 & \\
\hline GHAA.Se & Sample J800 & $(0.0690)$ & N/A & & 0.0690 & \\
\hline TCLP.GHAA.Se & Sample J723 & $<0.0125$ & N/A & & $<0.0125$ & \\
\hline Metal (Solid) & & $\mu \mathrm{g} / \mathrm{g}$ & $\mu \mathrm{g} / \mathrm{g}$ & $\mu g / g$ & $\mu g / g$ & $\mathrm{~kg}$ \\
\hline \multirow[t]{5}{*}{ ICP.w.Se } & Sample J691 & 114 & \multirow{5}{*}{$\begin{array}{l}18.4 \\
\text { to } \\
114\end{array}$} & \multirow[t]{5}{*}{49.2} & \multirow[t]{5}{*}{---} & \multirow[t]{24}{*}{110} \\
\hline & Sample J704 & $(26.4)$ & & & & \\
\hline & Sample $\mathrm{J707}$ & 18.4 & & & & \\
\hline & Sample $\mathrm{J} 711$ & $(62.2)$ & & & & \\
\hline & Sample J712 & $(55.8)$ & & & & \\
\hline \multirow{4}{*}{$\begin{array}{l}\text { ICP.a.Se } \\
\text { Segment } \\
\text { Sample }\end{array}$} & Sample J647 & $<7.60$ & \multirow{4}{*}{$\begin{array}{c}<7.60 \\
\text { to } \\
76.4\end{array}$} & \multirow[t]{4}{*}{--} & \multirow[t]{4}{*}{$\cdots$} & \\
\hline & Sample J649 & $<7.60$ & & & & \\
\hline & Sample J658 & $(76.4)$ & & & & \\
\hline & Sample J656 & $<8.30$ & & & & \\
\hline \multirow{5}{*}{$\begin{array}{r}\text { ICP.a.Se } \\
\text { Core } \\
\text { Sample }\end{array}$} & Sample $J 666$ & 28.6 & \multirow{5}{*}{$\begin{array}{c}<7.60 \\
\text { to } \\
112\end{array}$} & \multirow[t]{5}{*}{70.0} & \multirow[t]{5}{*}{--} & \\
\hline & Sample J667 & 26.3 & & & & \\
\hline & Sample J672 & $(112)$ & & & & \\
\hline & Sample J680 & $<7.60$ & & & & \\
\hline & Sample J683 & $<7.60$ & & & & \\
\hline \multirow[t]{5}{*}{ ICP.f.Se } & Sample J715 & $(181)$ & \multirow{5}{*}{$\begin{array}{c}<41.5 \\
\text { to } \\
181\end{array}$} & \multirow{5}{*}{80.0} & \multirow[t]{5}{*}{---} & \\
\hline & Sample J716 & $(147)$ & & & & \\
\hline & Sample J719 & $(50.9)$ & & & & \\
\hline & Sample $\mathrm{J} 723$ & $(<41.5)$ & & & & \\
\hline & Sample J724 & $(<41.5)$ & & & & \\
\hline \multirow[t]{5}{*}{ GHAA.Se } & Sample J666 & $(0.653)$ & \multirow{5}{*}{$\begin{array}{c}0.609 \\
\text { to } \\
1.71\end{array}$} & \multirow[t]{5}{*}{0.928} & \multirow[t]{5}{*}{--} & \\
\hline & Sample J667 & 0.756 & & & & \\
\hline & Sample J672 & 0.609 & & & & \\
\hline & Sample J680 & 1.22 & & & & \\
\hline & Sample J683 & 1.71 & & & & \\
\hline
\end{tabular}


Table A-1. Tank 241-C-110 Analytical Data: Silicon

\begin{tabular}{|c|c|c|c|c|c|c|}
\hline Analyte & $\begin{array}{c}\text { Laboratory } \\
\text { Sample } \\
\text { Identification }\end{array}$ & $\begin{array}{c}\text { Analytical } \\
\text { Data } \\
\text { Result }\end{array}$ & $\begin{array}{c}\text { Range } \\
\text { of } \\
\text { Values }\end{array}$ & $\begin{array}{c}\text { Weighted } \\
\text { Mean/ } \\
\text { Standard } \\
\text { Error }\end{array}$ & $\begin{array}{c}\text { Evaluated } \\
\text { Data } \\
\text { Result }\end{array}$ & $\begin{array}{l}\text { Projected } \\
\text { Inventory }\end{array}$ \\
\hline Metal (Liquid) & & $\mu \mathrm{g} / \mathrm{mL}$ & $\mu \mathrm{g} / \mathrm{mL}$ & $\mu \mathrm{g} / \mathrm{mL}$ & $\mu \mathrm{g} / \mathrm{mL}$ & $\mathrm{kg}$ \\
\hline \multirow[t]{4}{*}{ ICP.d.Si } & Sample J783 & $(10.6)$ & \multirow{4}{*}{$\begin{array}{c}10.6 \\
\text { to } \\
144\end{array}$} & \multirow[t]{4}{*}{--} & \multirow[t]{4}{*}{65.5} & \multirow[t]{4}{*}{1.74} \\
\hline & Sample J778 & $(74.5)$ & & & & \\
\hline & Sample J775 & $(32.7)$ & & & & \\
\hline & Sample J800 & $(144)$ & & & & \\
\hline Metal (Solid) & & $\mu \mathrm{g} / \mathrm{g}$ & $\mu \mathrm{g} / \mathrm{g}$ & $\mu \mathrm{g} / \mathrm{g}$ & $\mu \mathrm{g} / \mathrm{g}$ & $\mathrm{kg}$ \\
\hline \multirow[t]{5}{*}{ ICP.w.Si } & Sample J691 & $(491)$ & \multirow{5}{*}{$\begin{array}{l}25.4 \\
\text { to } \\
491\end{array}$} & \multirow{5}{*}{79.7} & \multirow[t]{5}{*}{$\cdots$} & \multirow[t]{19}{*}{7,350} \\
\hline & Sample $J 704$ & 25.4 & & & & \\
\hline & Sample J707 & $(217)$ & & & & \\
\hline & Sample $\mathrm{J711}$ & $(282)$ & & & & \\
\hline & Sample J712 & $(186)$ & & & & \\
\hline \multirow{4}{*}{$\begin{array}{l}\text { ICP.a.Si } \\
\text { Segment } \\
\text { Sample }\end{array}$} & Sample J647 & $(357)$ & \multirow{4}{*}{$\begin{array}{l}357 \\
\text { to } \\
812\end{array}$} & \multirow[t]{4}{*}{---} & \multirow[t]{4}{*}{--} & \\
\hline & Sample J649 & $(381)$ & & & & \\
\hline & Sample J658 & (639) & & & & \\
\hline & Sample J656 & $(812)$ & & & & \\
\hline \multirow{5}{*}{$\begin{array}{r}\text { ICP.a.Si } \\
\text { Core } \\
\text { Sample }\end{array}$} & Sample J666 & $(907)$ & \multirow{5}{*}{$\begin{array}{l}340 \\
\text { to } \\
990\end{array}$} & \multirow[t]{5}{*}{726} & \multirow[t]{5}{*}{$\cdots$} & \\
\hline & Sample J667 & $(731)$ & & & & \\
\hline & Sample J672 & $(990)$ & & & & \\
\hline & Sample J680 & 397 & & & & \\
\hline & Sample J683 & 340 & & & & \\
\hline \multirow[t]{5}{*}{ ICP.t.Si } & Sample J715 & $(7,500)$ & \multirow{5}{*}{$\begin{array}{c}6,270 \\
\text { to } \\
7,720\end{array}$} & \multirow[t]{5}{*}{7,160} & \multirow[t]{5}{*}{--} & \\
\hline & Sample J716 & $(7,380)$ & & & & \\
\hline & Sample J719 & $(7,720)$ & & & & \\
\hline & Sample $\mathrm{J} 723$ & $(6,400)$ & & & & \\
\hline & Sample J724 & $(6,270)$ & & & & \\
\hline
\end{tabular}


Table A-1. Tank 241-C-110 Analytical Data: Silver

\begin{tabular}{|c|c|c|c|c|c|c|}
\hline Analyte & $\begin{array}{l}\text { Laboratory } \\
\text { Sample } \\
\text { Identification }\end{array}$ & $\begin{array}{c}\text { Analytical } \\
\text { Data } \\
\text { Result }\end{array}$ & $\begin{array}{l}\text { Range } \\
\text { of } \\
\text { Values }\end{array}$ & $\begin{array}{c}\text { Weighted } \\
\text { Mean/ } \\
\text { Standard } \\
\text { Error }\end{array}$ & $\begin{array}{c}\text { Evaluated } \\
\text { Data } \\
\text { Result }\end{array}$ & $\begin{array}{l}\text { Projected } \\
\text { Inventory }\end{array}$ \\
\hline Metal (Liquid) & & $\mu \mathrm{g} / \mathrm{mL}$ & $\mu \mathrm{g} / \mathrm{mL}$ & $\mu \mathrm{g} / \mathrm{mL}$ & $\mu \mathrm{g} / \mathrm{mL}$ & $\mathrm{kg}$ \\
\hline \multirow[t]{4}{*}{ ICP.d.Ag } & Sample $J 783$ & $(0.500)$ & \multirow{4}{*}{$\begin{array}{l}0.500^{\circ} \\
\text { to } \\
1.17\end{array}$} & \multirow[t]{4}{*}{--} & \multirow[t]{4}{*}{0.798} & \multirow[t]{5}{*}{0.0211} \\
\hline & Sample J778 & $(0.510)$ & & & & \\
\hline & Sample $\mathrm{J} 775$ & $(1.17)$ & & & & \\
\hline & Sample J800 & $(1.01)$ & & & & \\
\hline TCLP.ICP.Ag & Sample J723 & $<0.0504$ & N/A & & $<0.0504$ & \\
\hline Metal (Solid) & & $\mu \mathrm{g} / \mathrm{g}$ & $\mu \mathrm{g} / \mathrm{g}$ & $\mu \mathrm{g} / \mathrm{g}$ & $\mu \mathrm{g} / \mathrm{g}$ & $\mathrm{kg}$ \\
\hline \multirow[t]{5}{*}{ ICP.w.Ag } & Sample J691 & $(1.02)$ & \multirow{5}{*}{$\begin{array}{l}0.550 \\
\text { to } \\
2.13\end{array}$} & \multirow{5}{*}{0.516} & \multirow[t]{5}{*}{--} & \multirow[t]{19}{*}{1.08} \\
\hline & Sample J704 & 2.13 & & & & \\
\hline & Sample J707 & 0.550 & & & & \\
\hline & Sample J711 & $(1.02)$ & & & & \\
\hline & Sample J712 & $(1.02)$ & & & & \\
\hline \multirow{4}{*}{$\begin{array}{l}\text { ICP.a.Ag } \\
\text { Segment } \\
\text { Sample }\end{array}$} & Sample J647 & $(<0.490)$ & \multirow{4}{*}{$\begin{array}{l}<0.476 \\
\text { to } \\
<0.985\end{array}$} & \multirow[t]{4}{*}{$\cdots$} & \multirow[t]{4}{*}{$\cdots$} & \\
\hline & Sample J649 & $(<0.476)$ & & & & \\
\hline & Sample J658 & $(<0.951)$ & & & & \\
\hline & Sample J656 & $1<0.985)$ & & & & \\
\hline \multirow[t]{5}{*}{ ICP.a.Ag } & Sample J666 & $(0.503)$ & \multirow[t]{5}{*}{ N/A } & \multirow[t]{5}{*}{0.733} & \multirow[t]{5}{*}{--} & \\
\hline & Sample J667 & $<0.500$ & & & & \\
\hline & Sample J672 & $<1.00$ & & & & \\
\hline & Sample J680 & $1<0.500)$ & & & & \\
\hline & Sample J683 & $(0.963)$ & & & & \\
\hline \multirow[t]{5}{*}{ ICP.f.Ag } & Sample $J 715$ & $(<5.00)$ & \multirow[t]{5}{*}{$N / A$} & \multirow[t]{5}{*}{---} & \multirow[t]{5}{*}{$<5.00$} & \\
\hline & Sample J716 & $(<5.00)$ & & & & \\
\hline & Sample J719 & $(<5.00)$ & & & & \\
\hline & Sample J723 & $(<5.00)$ & & & & \\
\hline & Sample J724 & $(<5.00)$ & & & & \\
\hline
\end{tabular}


Table A-1. Tank 241-C-110 Analytical Data: Sodium

\begin{tabular}{|c|c|c|c|c|c|c|}
\hline $\begin{array}{c}\text { Analyte } \\
\ldots\end{array}$ & $\begin{array}{l}\text { Laboratory } \\
\text { Sample } \\
\text { Identification }\end{array}$ & $\begin{array}{c}\text { Analytical } \\
\text { Data } \\
\text { Result }\end{array}$ & $\begin{array}{c}\text { Range } \\
\text { of } \\
\text { Values }\end{array}$ & $\begin{array}{c}\text { Weighted } \\
\text { Mean/ } \\
\text { Standard } \\
\text { Error }\end{array}$ & $\begin{array}{c}\text { Evaluated } \\
\text { Data } \\
\text { Result }\end{array}$ & $\begin{array}{l}\text { Projected } \\
\text { Inventory }\end{array}$ \\
\hline Metal (Liquid) & & $\mu \mathrm{g} / \mathrm{mL}$ & $\mu \mathrm{g} / \mathrm{mL}$ & $\mu \mathrm{g} / \mathrm{mL}$ & $\mu \mathrm{g} / \mathrm{mL}$ & $\mathrm{kg}$ \\
\hline \multirow[t]{4}{*}{ ICP.d.Na } & Sample J783 & $(8,970)$ & \multirow{4}{*}{$\begin{array}{c}8,970 \\
\text { to } \\
92,600\end{array}$} & \multirow[t]{4}{*}{--} & \multirow[t]{4}{*}{44,700} & \multirow[t]{4}{*}{1,190} \\
\hline & Sample J778 & $(46,900)$ & & & & \\
\hline & Sample J775 & $(92,600)$ & & & & \\
\hline & Sample 1800 & $(30,400)$ & & & & \\
\hline Metal (Solid) & & $\mu \mathrm{g} / \mathrm{g}$ & $\mu \mathrm{g} / \mathrm{g}$ & $\mu \mathrm{g} / \mathrm{g}$ & $\mu \mathrm{g} / \mathrm{g}$ & $\mathrm{kg}$ \\
\hline \multirow[t]{5}{*}{ ICP.W.Na } & Sample J691 & $(94,900)$ & \multirow{5}{*}{$\begin{array}{c}9,740 \\
\text { to } \\
94,900\end{array}$} & \multirow[t]{5}{*}{66,300} & \multirow[t]{5}{*}{$\cdots$} & \multirow[t]{19}{*}{84,800} \\
\hline & Sample J704 & $(9,740)$ & & & & \\
\hline & Sample J707 & $(66,700)$ & & & & \\
\hline & Sample $J 711$ & $(77,000)$ & & & & \\
\hline & Sample J712 & $(82,500)$ & & & & \\
\hline \multirow{4}{*}{$\begin{array}{l}\text { ICP.a.Na } \\
\text { Segment } \\
\text { Sample }\end{array}$} & Sample J647 & $(79,000)$ & \multirow{4}{*}{$\begin{array}{c}77,300 \\
\text { to } \\
121,000\end{array}$} & \multirow[t]{4}{*}{--} & \multirow[t]{4}{*}{--} & \\
\hline & Sample J649 & $(79,500)$ & & & & \\
\hline & Sample J658 & $(77,300)$ & & & & \\
\hline & Sample J656 & $(121,000)$ & & & & \\
\hline \multirow{5}{*}{$\begin{array}{r}\text { ICP.a.Na } \\
\text { Core } \\
\text { Sample }\end{array}$} & Sample J666 & $(84,800)$ & \multirow{5}{*}{$\begin{array}{c}59,700 \\
\text { to } \\
84,800\end{array}$} & \multirow[t]{5}{*}{77,000} & \multirow[t]{5}{*}{---} & \\
\hline & Sample J667 & $(83,800)$ & & & & \\
\hline & Sample J672 & $(79,900)$ & & & & \\
\hline & Sample J680 & $(74,000)$ & & & & \\
\hline & Sample J683 & $(59,700)$ & & & & \\
\hline \multirow[t]{5}{*}{ ICP.f.Na } & Sample J715 & $(80,600)$ & \multirow{5}{*}{$\begin{array}{c}77,300 \\
\text { to } \\
88,500\end{array}$} & \multirow[t]{5}{*}{82,600} & \multirow[t]{5}{*}{--} & \\
\hline & Sample J716 & $(85,300)$ & & & & \\
\hline & Sample J719 & $(77,300)$ & & & & \\
\hline & Sample J723 & $(88,500)$ & & & & \\
\hline & Sample $J 724$ & $(86,800)$ & & & & \\
\hline
\end{tabular}


WHC-SD-WM-ER-367 REV O

Table A-1. Tank 241-C-110 Analytical Data: Strontium

\begin{tabular}{|c|c|c|c|c|c|c|}
\hline Analyte & $\begin{array}{c}\text { Laboratory } \\
\text { Sample } \\
\text { Identification }\end{array}$ & $\begin{array}{c}\text { Analytical } \\
\text { Data } \\
\text { Result }\end{array}$ & $\begin{array}{c}\text { Range } \\
\text { of } \\
\text { Values }\end{array}$ & $\begin{array}{c}\text { Weighted } \\
\text { Mean/ } \\
\text { Standard } \\
\text { Error }\end{array}$ & $\begin{array}{c}\text { Evaluated } \\
\text { Data } \\
\text { Result }\end{array}$ & $\begin{array}{l}\text { Projected } \\
\text { Inventory }\end{array}$ \\
\hline Metal (Liquid) & & $\mu \mathrm{g} / \mathrm{mL}$ & $\mu \mathrm{g} / \mathrm{mL}$ & $\mu \mathrm{g} / \mathrm{ml}$ & $\mu \mathrm{g} / \mathrm{mL}$ & $\mathrm{kg}$ \\
\hline \multirow[t]{4}{*}{ ICP.d.Sr } & Sample $\mathbf{J 7 8 3}$ & $(0.200)$ & \multirow{4}{*}{$\begin{array}{l}0.200 \\
\text { to } \\
1.59\end{array}$} & \multirow[t]{4}{*}{---} & \multirow[t]{4}{*}{0.807} & \multirow[t]{4}{*}{0.0214} \\
\hline & Sample $J 778$ & $(1.14)$ & & & & \\
\hline & Sample $J 775$ & $(0.298)$ & & & & \\
\hline & Sample $\mathrm{J} 800$ & $(1.59)$ & & & & \\
\hline Metal (Solid) & & $\mu \mathrm{g} / \mathrm{g}$ & $\mu \mathrm{g} / \mathrm{g}$ & $\mu \mathrm{g} / \mathrm{g}$ & $\mu \mathrm{g} / \mathrm{g}$ & $\mathrm{kg}$ \\
\hline \multirow[t]{5}{*}{ ICP.w.Sr } & Sample J691 & $(19.0)$ & \multirow{5}{*}{$\begin{array}{l}1.58 \\
\text { to } \\
19.0\end{array}$} & \multirow[t]{5}{*}{5.25} & \multirow[t]{5}{*}{$-\cdots$} & \multirow[t]{19}{*}{134} \\
\hline & Sample J704 & $(17.0)$ & & & & \\
\hline & Sample J707 & $(3.80)$ & & & & \\
\hline & Sample J711 & $(1.59)$ & & & & \\
\hline & Sample $\mathrm{J} 712$ & $(1.58)$ & & & & \\
\hline \multirow{4}{*}{$\begin{array}{l}\text { ICP.a.Sr } \\
\text { Segment } \\
\text { Sample }\end{array}$} & Sample J647 & $(174)$ & \multirow{4}{*}{$\begin{array}{l}73.3 \\
\text { to } \\
174\end{array}$} & \multirow[t]{4}{*}{--} & \multirow[t]{4}{*}{--- } & \\
\hline & Sample J649 & $(172)$ & & & & \\
\hline & Sample J658 & $(102)$ & & & & \\
\hline & Sample J656 & $(73.3)$ & & & & \\
\hline \multirow{5}{*}{$\begin{array}{c}\text { ICP.a.Sr } \\
\text { Core } \\
\text { Sample }\end{array}$} & Sample J666 & $(150)$ & \multirow{5}{*}{$\begin{array}{l}80.5 \\
\text { to } \\
152\end{array}$} & \multirow[t]{5}{*}{128} & \multirow[t]{5}{*}{--} & \\
\hline & Sample J667 & $(152)$ & & & & \\
\hline & Sample J672 & $(149)$ & & & & \\
\hline & Sample J680 & $(80.5)$ & & & & \\
\hline & Sample J683 & $(90.1)$ & & & & \\
\hline \multirow[t]{5}{*}{ ICP.f.Sr } & Sample J715 & $(140)$ & \multirow{5}{*}{$\begin{array}{c}84.3 \\
\text { to } \\
162\end{array}$} & \multirow[t]{5}{*}{131} & \multirow[t]{5}{*}{$\cdots$} & \\
\hline & Sample J716 & $(162)$ & & & & \\
\hline & Sample J719 & $(156)$ & & & & \\
\hline & Sample $\mathrm{J} 723$ & $(86.8)$ & & & & \\
\hline & Sample J724 & $(84.3)$ & & & & \\
\hline
\end{tabular}


Table A-1. Tank 241-C-110 Analytical Data: Sulfur

\begin{tabular}{|c|c|c|c|c|c|c|}
\hline Analyte & $\begin{array}{l}\text { Laboratory } \\
\text { Sample } \\
\text { Identification }\end{array}$ & $\begin{array}{c}\text { Analytical } \\
\text { Data } \\
\text { Result }\end{array}$ & $\begin{array}{c}\text { Range } \\
\text { of } \\
\text { Values }\end{array}$ & $\begin{array}{c}\text { Weighted } \\
\text { Mean/ } \\
\text { Standard } \\
\text { Error }\end{array}$ & $\begin{array}{c}\text { Evaluated } \\
\text { Data } \\
\text { Result }\end{array}$ & $\begin{array}{l}\text { Projected } \\
\text { Inventory }\end{array}$ \\
\hline Metal (Liquid) & & $\mu \mathrm{g} / \mathrm{mL}$ & $\mu \mathrm{g} / \mathrm{mL}$ & $\mu \mathrm{g} / \mathrm{mL}$ & $\mu \mathrm{g} / \mathrm{mL}$ & $\mathrm{kg}$ \\
\hline \multirow[t]{4}{*}{ ICP.d.S } & Sample J783 & $(534)$ & \multirow{4}{*}{$\begin{array}{c}534 \\
\text { to } \\
6,210\end{array}$} & \multirow[t]{4}{*}{--} & \multirow[t]{4}{*}{2,950} & \multirow[t]{4}{*}{78.2} \\
\hline & Sample J778 & $(3,110)$ & & & & \\
\hline & Sample $J 775$ & $(6,210)$ & & & & \\
\hline & Sample J800 & $(1,950)$ & & & & \\
\hline Metal (Solid) & & $\mu \mathrm{g} / \mathrm{g}$ & $\mu g / g$ & $\mu \mathrm{g} / \mathrm{g}$ & $\mu g / g$ & $\mathrm{~kg}$ \\
\hline \multirow[t]{5}{*}{ ICP.w.S } & Sample J691 & $(4,340)$ & \multirow{5}{*}{$\begin{array}{c}423 \\
\text { to } \\
4,760\end{array}$} & \multirow[t]{2}{*}{3,650} & \multirow[t]{5}{*}{--} & \multirow[t]{19}{*}{4,190} \\
\hline & Sample J704 & $(423)$ & & & & \\
\hline & Sample J707 & $(3,880)$ & & \multirow[t]{3}{*}{858} & & \\
\hline & Sample J711 & $(4,760)$ & & & & \\
\hline & Sample J712 & $(4,610)$ & & & & \\
\hline \multirow{4}{*}{$\begin{array}{l}\text { ICP.a.S } \\
\text { Segment } \\
\text { Sample }\end{array}$} & Sample J647 & $(4,270)$ & \multirow{4}{*}{$\begin{array}{l}3,540 \\
\text { to } \\
4,300\end{array}$} & \multirow[t]{4}{*}{--- } & \multirow[t]{4}{*}{--} & \\
\hline & Sample J649 & $(4,300)$ & & & & \\
\hline & Sample J658 & $(3,580)$ & & & & \\
\hline & Sample J656 & $(3,540)$ & & & & \\
\hline \multirow{5}{*}{$\begin{array}{r}\text { ICP.a.S } \\
\text { Core } \\
\text { Sample }\end{array}$} & Sample J666 & $(3,610)$ & \multirow{5}{*}{$\begin{array}{c}3,580 \\
\text { to } \\
4,790\end{array}$} & \multirow[t]{5}{*}{4,080} & \multirow[t]{5}{*}{$\cdots$} & \\
\hline & Sample J667 & $(3,580)$ & & & & \\
\hline & Sample J672 & $(3,900)$ & & & & \\
\hline & Sample J680 & $(4,790)$ & & & & \\
\hline & Sample J683 & $(4,690)$ & & & & \\
\hline \multirow[t]{5}{*}{ ICP.f.S } & Sample J715 & $(3,390)$ & \multirow{5}{*}{$\begin{array}{l}3,310 \\
\text { to } \\
4,820\end{array}$} & \multirow[t]{5}{*}{3,960} & \multirow[t]{5}{*}{---} & \\
\hline & Sample J716 & $(3,310)$ & & & & \\
\hline & Sample J719 & $(3,760)$ & & & & \\
\hline & Sample J723 & $(4,820)$ & & & & \\
\hline & Sample J724 & $(4,710)$ & & & & \\
\hline
\end{tabular}


Table A-1. Tank 241-C-110 Analytical Data: Tin

\begin{tabular}{|c|c|c|c|c|c|c|}
\hline Analyte & $\begin{array}{l}\text { Laboratory } \\
\text { Sample } \\
\text { Identification }\end{array}$ & $\begin{array}{c}\text { Analytical } \\
\text { Data } \\
\text { Result }\end{array}$ & $\begin{array}{l}\text { Range } \\
\text { of } \\
\text { Values }\end{array}$ & $\begin{array}{l}\text { Weighted } \\
\text { Mean/ } \\
\text { Standard } \\
\text { Error }\end{array}$ & $\begin{array}{c}\text { Evaluated } \\
\text { Data } \\
\text { Result }\end{array}$ & $\begin{array}{l}\text { Projected } \\
\text { Inventory }\end{array}$ \\
\hline Metal (Liquid) & & $\mu \mathrm{g} / \mathrm{mL}$ & $\mu \mathrm{g} / \mathrm{mL}$ & $\mu \mathrm{g} / \mathrm{mL}$ & $\mu \mathrm{g} / \mathrm{mL}$ & $\mathrm{kg}$ \\
\hline \multirow[t]{4}{*}{ ICP.d.Sn } & Sample J783 & $(1.15)$ & \multirow{4}{*}{$\begin{array}{l}1.15 \\
\text { to } \\
2.32\end{array}$} & & \multirow[t]{4}{*}{1.45} & \multirow[t]{4}{*}{0.0384} \\
\hline & Sample $J 778$ & $(1.17)$ & & & & \\
\hline & Sample $\mathrm{J775}$ & $(1.17)$ & & & & \\
\hline & Sample J800 & $(2.32)$ & & & & \\
\hline Metal (Solid) & & $\mu \mathrm{g} / \mathrm{g}$ & $\mu \mathrm{g} / \mathrm{g}$ & $\mu \mathrm{g} / \mathrm{g}$ & $\mu \mathrm{g} / \mathrm{g}$ & $\mathrm{kg}$ \\
\hline \multirow[t]{5}{*}{ ICP.w.Sn } & Sample J691 & $(2.34)$ & \multirow{5}{*}{$\begin{array}{l}1.63 \\
\text { to } \\
3.22\end{array}$} & \multirow{5}{*}{0.580} & \multirow[t]{5}{*}{---} & \multirow[t]{19}{*}{13.1} \\
\hline & Sample J704 & $(3.22)$ & & & & \\
\hline & Sample J707 & $(1.63)$ & & & & \\
\hline & Sample J711 & $(2.34)$ & & & & \\
\hline & Sample $\mathrm{J} 712$ & $(2.34)$ & & & & \\
\hline \multirow{4}{*}{$\begin{array}{l}\text { ICP.a.Sn } \\
\text { Segment } \\
\text { Sample }\end{array}$} & Sample J647 & $(7.90)$ & \multirow{4}{*}{$\begin{array}{l}7.90 \\
\text { to } \\
11.3\end{array}$} & \multirow[t]{4}{*}{--} & \multirow[t]{4}{*}{---} & \\
\hline & Sample J649 & $(9.12)$ & & & & \\
\hline & Sample J658 & $(11.3)$ & & & & \\
\hline & Sample J656 & $(9.26)$ & & & & \\
\hline \multirow{5}{*}{$\begin{array}{r}\text { ICP.a.Sn } \\
\text { Core } \\
\text { Sample }\end{array}$} & Sample J666 & $(7.73)$ & \multirow{5}{*}{$\begin{array}{l}6.72 \\
\text { to } \\
9.37\end{array}$} & \multirow[t]{5}{*}{8.02} & \multirow[t]{5}{*}{--} & \\
\hline & Sample J667 & $(6.72)$ & & & & \\
\hline & Sample J672 & $(9.37)$ & & & & \\
\hline & Sample J680 & $(6.94)$ & & & & \\
\hline & Sample J683 & $(8.00)$ & & & & \\
\hline \multirow[t]{5}{*}{ ICP.f.Sn } & Sample J715 & $(11.5)$ & \multirow{5}{*}{$\begin{array}{c}11.4 \\
\text { to } \\
18.2\end{array}$} & \multirow[t]{5}{*}{12.8} & \multirow[t]{5}{*}{--} & \\
\hline & Sample $J 716$ & $(11.4)$ & & & & \\
\hline & Sample J719 & $(11.5)$ & & & & \\
\hline & Sample J723 & $(12.3)$ & & & & \\
\hline & Sample J724 & $(18.2)$ & & & & \\
\hline
\end{tabular}


WHC-SD-WM-ER-367 REV O

Table A-1. Tank 241-C-110 Analytical Data: Titanium

\begin{tabular}{|c|c|c|c|c|c|c|}
\hline Analyte & $\begin{array}{l}\text { Laboratory } \\
\text { Sample } \\
\text { Identification }\end{array}$ & $\begin{array}{l}\text { Analytical } \\
\text { Data } \\
\text { Result }\end{array}$ & $\begin{array}{c}\text { Range } \\
\text { of } \\
\text { Values }\end{array}$ & $\begin{array}{l}\text { Weighted } \\
\text { Mean/ } \\
\text { Standard } \\
\text { Error }\end{array}$ & $\begin{array}{c}\text { Evaluated } \\
\text { Data } \\
\text { Result }\end{array}$ & $\begin{array}{l}\text { Projected } \\
\text { Inventory }\end{array}$ \\
\hline Metal (Liquid) & & $\mu \mathrm{g} / \mathrm{mL}$ & $\mu \mathrm{g} / \mathrm{mL}$ & $\mu \mathrm{g} / \mathrm{mL}$ & $\mu \mathrm{g} / \mathrm{mL}$ & $\mathrm{kg}$ \\
\hline \multirow[t]{4}{*}{ ICP.d.Ti } & Sample J783 & $(0.200)$ & \multirow{4}{*}{$\begin{array}{l}0.200 \\
\text { to } \\
0.404\end{array}$} & \multirow[t]{4}{*}{--} & \multirow[t]{4}{*}{0.253} & \multirow[t]{4}{*}{0.00670} \\
\hline & Sample $J 778$ & $(0.204)$ & & & & \\
\hline & Sample J775 & $(0.204)$ & & & & \\
\hline & Sample J800 & $(0.404)$ & & & & \\
\hline Metal (Solid) & & $\mu \mathrm{g} / \mathrm{g}$ & $\mu \mathrm{g} / \mathrm{g}$ & $\mu \mathrm{g} / \mathrm{g}$ & $\mu \mathrm{g} / \mathrm{g}$ & $\mathrm{kg}$ \\
\hline \multirow[t]{5}{*}{ ICP.w.Ti } & Sample J691 & $(1.15)$ & \multirow{5}{*}{$\begin{array}{l}0.406 \\
\text { to } \\
1.15\end{array}$} & \multirow[t]{5}{*}{0.631} & \multirow[t]{5}{*}{--} & \multirow[t]{19}{*}{10.8} \\
\hline & Sample J704 & $(1.01)$ & & & & \\
\hline & Sample J707 & $(0.407)$ & & & & \\
\hline & Sample $J 711$ & $(0.406)$ & & & & \\
\hline & Sample J712 & $(0.407)$ & & & & \\
\hline \multirow{4}{*}{$\begin{array}{c}\text { ICP.a.Ti } \\
\text { Segment } \\
\text { Sample }\end{array}$} & Sample J647 & $(4.41)$ & \multirow{4}{*}{$\begin{array}{l}4.40 \\
\text { to } \\
5.38\end{array}$} & \multirow[t]{4}{*}{$\cdots$} & \multirow[t]{4}{*}{$\cdots$} & \\
\hline & Sample J649 & $(4.40)$ & & & & \\
\hline & Sample J658 & $(5.38)$ & & & & \\
\hline & Sample J656 & $(5.17)$ & & & & \\
\hline \multirow{5}{*}{$\begin{array}{r}\text { ICP.a.Ti } \\
\text { Core } \\
\text { Sample }\end{array}$} & Sample J666 & $(5.46)$ & \multirow{5}{*}{$\begin{array}{l}4.03 \\
\text { to } \\
5.50\end{array}$} & \multirow{5}{*}{0.336} & \multirow[t]{5}{*}{--} & \\
\hline & Sample J667 & $(5.16)$ & & & & \\
\hline & Sample J672 & $(5.50)$ & & & & \\
\hline & Sample J680 & $(4.03)$ & & & & \\
\hline & Sample $J 683$ & $(4.85)$ & & & & \\
\hline \multirow[t]{5}{*}{ ICP.f.Ti } & Sample J715 & $(6.45)$ & \multirow{5}{*}{$\begin{array}{c}6.45 \\
\text { to } \\
14.3\end{array}$} & \multirow[t]{5}{*}{10.5} & \multirow[t]{5}{*}{$-\cdots$} & \\
\hline & Sample J716 & $(9.22)$ & & & & \\
\hline & Sample J719 & $(14.3)$ & & & & \\
\hline & Sample J723 & $(6.95)$ & & & & \\
\hline & Sample J724 & $(11.9)$ & & & & \\
\hline
\end{tabular}


Table A-1. Tank 241-C-110 Analytical Data: Uranium

\begin{tabular}{|c|c|c|c|c|c|c|}
\hline Analyte & $\begin{array}{l}\text { Laboratory } \\
\text { Sample } \\
\text { Identification }\end{array}$ & $\begin{array}{l}\text { Analytical } \\
\text { Daita } \\
\text { Result }\end{array}$ & $\begin{array}{l}\text { Range } \\
\text { of } \\
\text { Values }\end{array}$ & $\begin{array}{l}\text { Weighted } \\
\text { Mean/ } \\
\because \text { Standard } \\
\text { Error }\end{array}$ & $\begin{array}{c}\text { Evaluated } \\
\text { Data } \\
\text { Resuilt }\end{array}$ & $\begin{array}{l}\text { Projected } \\
\text { Inventory }\end{array}$ \\
\hline Metal (Liquid) & & $\mu \mathrm{g} / \mathrm{mL}$ & $\mu \mathrm{g} / \mathrm{mL}$ & $\mu \mathrm{g} / \mathrm{mL}$ & $\mu \mathrm{g} / \mathrm{mL}$ & $\mathrm{kg}$ \\
\hline LF.Total U & Sample J800 & $(322)$ & $N / A$ & -- & 322 & 8.53 \\
\hline Metal (Solid) & & $\mu \mathrm{g} / \mathrm{g}$ & $\mu \mathrm{g} / \mathrm{g}$ & $\mu \mathrm{g} / \mathrm{g}$ & $\mu \mathrm{g} / \mathrm{g}$ & $\mathrm{kg}$ \\
\hline \multirow[t]{5}{*}{ LF.Total U } & Sample J715 & $(2,020)$ & \multirow{5}{*}{$\begin{array}{l}1,010 \\
\text { to } \\
2,020\end{array}$} & \multirow[t]{5}{*}{1,480} & \multirow[t]{5}{*}{--} & \multirow[t]{5}{*}{1,520} \\
\hline & Sample $\mathrm{J} 716$ & $(2,010)$ & & & & \\
\hline & Sample J719 & $(1,390)$ & & & & \\
\hline & Sample J723 & $(1,010)$ & & & & \\
\hline & Sample J724 & $(1,110)$ & & & & \\
\hline
\end{tabular}


WHC-SD-WM-ER-367 REV O

Table A-1. Tank 241-C-110 Analytical Data: Vanadium

\begin{tabular}{|c|c|c|c|c|c|c|}
\hline Analyte & $\begin{array}{l}\text { Laboratory } \\
\text { Sample } \\
\text { Identification }\end{array}$ & $\begin{array}{c}\text { Analytical } \\
\text { Data } \\
\text { Result }\end{array}$ & $\begin{array}{c}\text { Range } \\
\text { of } \\
\text { Values }\end{array}$ & $\begin{array}{c}\text { Weighted } \\
\text { Mean/ } \\
\text { Standard } \\
\text { Error }\end{array}$ & $\begin{array}{c}\text { Evaluated } \\
\text { Data } \\
\text { Result }\end{array}$ & $\begin{array}{l}\text { Projected } \\
\text { Inventory }\end{array}$ \\
\hline Metal (Liquid) & & $\mu \mathrm{g} / \mathrm{mL}$ & $\mu \mathrm{g} / \mathrm{mL}$ & $\mu \mathrm{g} / \mathrm{mL}$ & $\mu \mathrm{g} / \mathbf{m L}$ & $\mathrm{kg}$ \\
\hline \multirow[t]{4}{*}{ ICP.d.V } & Sample $\mathbf{j 7 8 3}$ & $(0.400)$ & \multirow{4}{*}{$\begin{array}{l}0.400 \\
\text { to } \\
4.02\end{array}$} & \multirow[t]{4}{*}{--} & \multirow[t]{4}{*}{1.61} & \multirow[t]{4}{*}{0.0427} \\
\hline & Sample J778 & $(0.824)$ & & & & \\
\hline & Sample $\mathbf{J 7 7 5}$ & $(4.02)$ & & & & \\
\hline & Sample $J 800$ & $(1.19)$ & & & & \\
\hline Metal (Solid) & & $\mu \mathrm{g} / \mathrm{g}$ & $\mu \mathrm{g} / \mathrm{g}$ & $\mu \mathrm{g} / \mathrm{g}$ & $\mu g / g$ & $\mathrm{~kg}$ \\
\hline \multirow[t]{5}{*}{ ICP.w.V } & Sample J691 & $(1.02)$ & \multirow{5}{*}{$\begin{array}{l}0.509 \\
\text { to } \\
2.22\end{array}$} & \multirow{5}{*}{0.563} & \multirow[t]{5}{*}{$\cdots$} & \multirow[t]{19}{*}{6.33} \\
\hline & Sample J704 & $(2.22)$ & & & & \\
\hline & Sample J707 & $(0.509)$ & & & & \\
\hline & Sample J711 & $(0.820)$ & & & & \\
\hline & Sample J712 & $(1.00)$ & & & & \\
\hline \multirow{4}{*}{$\begin{array}{r}\text { ICP.a.V } \\
\text { Segment } \\
\text { Sample }\end{array}$} & Sample J647 & $(5.26)$ & \multirow{4}{*}{$\begin{array}{l}4.89 \\
\text { to } \\
6.73\end{array}$} & \multirow[t]{4}{*}{--} & \multirow[t]{4}{*}{--} & \\
\hline & Sample J649 & $(5.49)$ & & & & \\
\hline & Sample J658 & $(4.89)$ & & & & \\
\hline & Sample J656 & $(6.73)$ & & & & \\
\hline \multirow{5}{*}{$\begin{array}{r}\text { ICP.a.V } \\
\text { Core } \\
\text { Sample }\end{array}$} & Sample $J 666$ & $(8.15)$ & \multirow{5}{*}{$\begin{array}{l}3.96 \\
\text { to } \\
8.53\end{array}$} & \multirow[t]{5}{*}{6.17} & \multirow[t]{5}{*}{--} & \\
\hline & Sample J667 & $(8.53)$ & & & & \\
\hline & Sample J672 & $(3.96)$ & & & & \\
\hline & Sample J680 & $(5.96)$ & & & & \\
\hline & Sample J683 & $(6.43)$ & & & & \\
\hline \multirow[t]{5}{*}{ ICP.f.V } & Sample J715 & $(<4.00)$ & \multirow{5}{*}{$\begin{array}{c}<4.00 \\
\text { to } \\
6.69\end{array}$} & \multirow{5}{*}{0.877} & \multirow[t]{5}{*}{---} & \\
\hline & Sample $J 716$ & $(5.45)$ & & & & \\
\hline & Sample J719 & $(6.69)$ & & & & \\
\hline & Sample J723 & $(<4.00)$ & & & & \\
\hline & Sample J724 & $(<4.00)$ & & & & \\
\hline
\end{tabular}


WHC-SD-WM-ER-367 REV O

Table A-1. Tank 241-C-110 Analytical Data: Zinc

\begin{tabular}{|c|c|c|c|c|c|c|}
\hline Analyte & $\begin{array}{l}\text { Laboratory } \\
\text { Sample } \\
\text { Identification }\end{array}$ & $\begin{array}{c}\text { Analytical } \\
\text { Data } \\
\text { Result }\end{array}$ & $\begin{array}{l}\text { Range } \\
\text { of } \\
\text { Values }\end{array}$ & $\begin{array}{l}\text { Weighted } \\
\text { Mean/ } \\
\text { Standard } \\
\text { Error }\end{array}$ & $\begin{array}{c}\text { Evaluated } \\
\text { Data } \\
\text { Result }\end{array}$ & $\begin{array}{l}\text { Projected } \\
\text { Inventory }\end{array}$ \\
\hline Metal (Liquid) & & $\mu \mathrm{g} / \mathrm{mL}$ & $\mu \mathrm{g} / \mathrm{mL}$ & $\mu \mathrm{g} / \mathrm{mL}$ & $\mu \mathrm{g} / \mathrm{mL}$ & $\mathrm{kg}$ \\
\hline \multirow[t]{4}{*}{ ICP.d.Zn } & Sample J783 & $(1.25)$ & \multirow{4}{*}{$\begin{array}{l}1.25 \\
\text { to } \\
2.52\end{array}$} & \multirow[t]{4}{*}{--} & \multirow[t]{4}{*}{1.58} & \multirow[t]{4}{*}{0.0419} \\
\hline & Sample J778 & $(1.28)$ & & & & \\
\hline & Sample J775 & $(1.28)$ & & & & \\
\hline & Sample J800 & $(2.52)$ & & & & \\
\hline Metal (Solid) & & $\mu \mathrm{g} / \mathrm{g}$ & $\mu \mathrm{g} / \mathrm{g}$ & $\mu \mathrm{g} / \mathrm{g}$ & $\mu \mathrm{g} / \mathrm{g}$ & $\mathrm{kg}$ \\
\hline \multirow[t]{5}{*}{ ICP.w.Zn } & Sample J691 & $(31.5)$ & \multirow{5}{*}{$\begin{array}{l}3.73 \\
\text { to } \\
31.5\end{array}$} & \multirow[t]{2}{*}{11.3} & \multirow[t]{5}{*}{$-\cdots$} & \multirow[t]{19}{*}{230} \\
\hline & Sample J704 & $(5.03)$ & & & & \\
\hline & Sample J707 & $(11.7)$ & & 5.55 & & \\
\hline & Sample J711 & $(4.32)$ & & & & \\
\hline & Sample J712 & $(3.73)$ & & & & \\
\hline \multirow{4}{*}{$\begin{array}{l}\text { ICP.a.Zn } \\
\text { Segment } \\
\text { Sample }\end{array}$} & Sample J647 & 105 & \multirow{4}{*}{$\begin{array}{l}78.9 \\
\text { to } \\
156\end{array}$} & \multirow[t]{4}{*}{---} & \multirow[t]{4}{*}{--} & \\
\hline & Sample J649 & 145 & & & & \\
\hline & Sample J658 & 156 & & & & \\
\hline & Sample J656 & $(78.9)$ & & & & \\
\hline \multirow{5}{*}{$\begin{array}{r}\text { ICP.a.Zn } \\
\text { Core } \\
\text { Sample }\end{array}$} & Sample J666 & $(227)$ & \multirow{5}{*}{$\begin{array}{l}97.0 \\
\text { to } \\
227\end{array}$} & \multirow[t]{5}{*}{139} & \multirow[t]{5}{*}{---} & \\
\hline & Sample J667 & $(216)$ & & & & \\
\hline & Sample J672 & $(97.6)$ & & & & \\
\hline & Sample J680 & $(101)$ & & & & \\
\hline & Sample J683 & 97.0 & & & & \\
\hline \multirow[t]{5}{*}{ ICP.f.Zn } & Sample $J 715$ & 261 & \multirow{5}{*}{$\begin{array}{c}132 \\
\text { to } \\
<\quad 261\end{array}$} & \multirow[t]{5}{*}{224} & \multirow[t]{5}{*}{$\cdots$} & \\
\hline & Sample J716 & 243 & & & & \\
\hline & Sample J719 & $(248)$ & & & & \\
\hline & Sample J723 & $(132)$ & & & & \\
\hline & Sample J724 & $(210)$ & & & & \\
\hline
\end{tabular}


Table A-1. Tank 241-C-110 Analytical Data: Zirconium

\begin{tabular}{|c|c|c|c|c|c|c|}
\hline \begin{tabular}{lll} 
& \\
$A n a l y t e$ & $\ddots$ \\
\hdashline & $\cdots$
\end{tabular} & $\begin{array}{c}\text { Laboratory } \\
\text { Sample } \\
\text { Adentification } \\
\end{array}$ & $\begin{array}{l}\text { Analytical } \\
\therefore \text { Data } \\
\text { Result }\end{array}$ & $\begin{array}{l}\text { Range } \\
\text { of } \\
\text { Vạlues }\end{array}$ & $\begin{array}{l}\text { Weighted } \\
\text { Mean/ } \\
\text { Standard } \\
\text { Error }\end{array}$ & $\begin{array}{l}\text { Evaluated } \\
\text { Data } \\
\text { Reșuit }\end{array}$ & $\begin{array}{l}\text { Projected } \\
\text { Inventory }\end{array}$ \\
\hline Metal (Liquid) & & $\mu \mathrm{g} / \mathrm{mL}$ & $\mu \mathrm{g} / \mathrm{mL}$ & $\mu \mathrm{g} / \mathrm{mL}$ & $\mu \mathrm{g} / \mathrm{mL}$ & $\mathrm{kg}$ \\
\hline \multirow[t]{4}{*}{ ICP.d.Zr } & Sample $J 783$ & $(0.425)$ & \multirow{4}{*}{$\begin{array}{l}0.182 \\
\text { to } \\
0.876\end{array}$} & \multirow[t]{4}{*}{$\cdots$} & \multirow[t]{4}{*}{0.575} & \multirow[t]{4}{*}{0.0152} \\
\hline & Sample J778 & $(0.818)$ & & & & \\
\hline & Sample J775 & $(0.876)$ & & & & \\
\hline & Sample 1800 & $(0.182)$ & & & & \\
\hline Metal (Solid) & & $\mu \mathrm{g} / \mathrm{g}$ & $\mu \mathrm{g} / \mathrm{g}$ & $\mu g / g$ & $\mu g / g$ & $\mathrm{~kg}$ \\
\hline \multirow[t]{5}{*}{ ICP.W.Zr } & Sample J691 & $(40.4)$ & \multirow{5}{*}{$\begin{array}{l}2.22 \\
\text { to } \\
40.4\end{array}$} & \multirow[t]{5}{*}{11.8} & \multirow[t]{5}{*}{$-\cdots$} & \multirow[t]{19}{*}{177} \\
\hline & Sample J704 & $(2.22)$ & & & & \\
\hline & Sample $J 707$ & $(8.69)$ & & & & \\
\hline & Sample J711 & $(5.14)$ & & & & \\
\hline & Sample $\mathbf{J 1 1 2}$ & $(5.76)$ & & & & \\
\hline \multirow{4}{*}{$\begin{array}{l}\text { ICP.a.Zr } \\
\text { Segment } \\
\text { Sample }\end{array}$} & Sample J647 & $(32.2)$ & \multirow{4}{*}{$\begin{array}{l}29.7 \\
\text { to } \\
33.7\end{array}$} & \multirow[t]{4}{*}{$--\cdot$} & \multirow[t]{4}{*}{--} & \\
\hline & Sample J649 & $(33.7)$ & & & & \\
\hline & Sample J658 & $(30.0)$ & & & & \\
\hline & Sample J656 & $(29.7)$ & & & & \\
\hline \multirow{5}{*}{$\begin{array}{r}\text { ICP.a.Zr } \\
\text { Core } \\
\text { Sample }\end{array}$} & Sample J666 & $(46.6)$ & \multirow{5}{*}{$\begin{array}{c}26.3 \\
\text { to } \\
54.4\end{array}$} & \multirow[t]{2}{*}{41.6} & \multirow[t]{5}{*}{--} & \\
\hline & Sample J667 & $(41.6)$ & & & & \\
\hline & Sample J672 & $(54.4)$ & & 8.20 & & \\
\hline & Sample J680 & $(26.3)$ & & & & \\
\hline & Sample J683 & $(26.3)$ & & & & \\
\hline \multirow[t]{5}{*}{ ICP.f.Zr } & Sample J715 & $(170)$ & \multirow{5}{*}{$\begin{array}{l}135 \\
\text { to } \\
199\end{array}$} & \multirow[t]{5}{*}{172} & \multirow[t]{5}{*}{$\cdots$} & \\
\hline & Sample J716 & $(178)$ & & & & \\
\hline & Sample J719 & $(199)$ & & & & \\
\hline & Sample $\mathbf{J 7 2 3}$ & $(153)$ & & & & \\
\hline & Sample J724 & $(135)$ & & & & \\
\hline
\end{tabular}


Table A-2. Tank 241-C-110 Analytical Data: Ammonium

\begin{tabular}{|c|c|c|c|c|c|c|}
\hline $\begin{array}{cc}\text { Analyte } \\
\cdots\end{array}$ & $\begin{array}{l}\text { Laboratory } \\
\text { "Sample } \\
\text { fdentification }\end{array}$ & $\begin{array}{l}\text { Analytical . } \\
\text { Data } \\
\text { Result : .... }\end{array}$ & $\begin{array}{l}\text { Range } \\
\text { of } . \\
\text { Values }\end{array}$ & $\begin{array}{c}\text { Weighted } \\
\text { Mean/ } \\
\text { Standard } \\
\text { Error }\end{array}$ & $\begin{array}{l}\text { Evaluated } \\
\therefore \text { Data } \\
\text { Result }\end{array}$ & $\begin{array}{c}\text { Projected } \\
\text { Inveñtory } \\
\vdots \\
\therefore\end{array}$ \\
\hline Cation (Liquid) & & $\mu \mathrm{g} / \mathrm{mL}$ & $\mu \mathrm{g} / \mathrm{mL}$ & $\mu \mathrm{g} / \mathrm{mL}$ & $\mu \mathrm{g} / \mathrm{mL}$ & $\mathrm{kg}$ \\
\hline Dist/Tit. $\mathrm{NH}_{4}{ }^{+}$ & Sample J800 & $(86.4)$ & N/A & -- & 86.4 & 2.29 \\
\hline Cation (Solid) & & $\mu g / g$ & $\mu \mathrm{g} / \mathrm{g}$ & $\mu \mathrm{g} / \mathrm{g}$ & $\mu g / g$ & $\mathrm{~kg}$ \\
\hline \multirow[t]{5}{*}{ Dist/Tit. $\mathrm{NH}_{4}{ }^{+}$} & Sample J691 & $<4,500$ & \multirow[t]{5}{*}{ N/A } & \multirow[t]{5}{*}{$\cdots$} & \multirow[t]{5}{*}{$<4,500$} & \multirow[t]{5}{*}{$<4,620$} \\
\hline & Sample 1704 & $<4,500$ & & & & \\
\hline & Sample J707 & $<4,500$ & & & & \\
\hline & Sample J711 & $<4,500$ & & & & \\
\hline & Sample $J 712$ & $<4,500$ & & & & \\
\hline
\end{tabular}

Table A-2. Tank 241-C-110 Analytical Data: Chloride

\begin{tabular}{|c|c|c|c|c|c|c|}
\hline Analyte & $\begin{array}{c}\text { Laboratory } \\
\text { Sample } \\
\text { Identification }\end{array}$ & $\begin{array}{c}\text { Analytical } \\
\text { Data } \\
\text { Result }\end{array}$ & $\begin{array}{c}\text { Range } \\
\text { of } \\
\text { Values }\end{array}$ & $\begin{array}{c}\text { Weighted } \\
\text { Mean/ } \\
\text { Standard } \\
\text { Error }\end{array}$ & $\begin{array}{c}\text { Evaluated } \\
\text { Data } \\
\text { Result }\end{array}$ & $\begin{array}{l}\text { Projected } \\
\text { Inventory }\end{array}$ \\
\hline Anion (Liquid) & & $\mu \mathrm{g} / \mathrm{mL}$ & $\mu \mathrm{g} / \mathrm{mL}$ & $\mu \mathrm{g} / \mathrm{mL}$ & $\mu \mathrm{g} / \mathrm{mL}$ & $\mathrm{kg}$ \\
\hline \multirow[t]{4}{*}{ IC.d.Cl' } & Sample J800 & 729 & \multirow{4}{*}{$\begin{array}{c}365 \\
\text { to } \\
1,910\end{array}$} & \multirow[t]{4}{*}{---} & \multirow[t]{4}{*}{996} & \multirow[t]{4}{*}{26.4} \\
\hline & Sample J783 & 365 & & & & \\
\hline & Sample J778 & 979 & & & & \\
\hline & Sample J775 & 1,910 & & & & \\
\hline Anion (Solid) & & $\mu \mathrm{g} / \mathrm{g}$ & $\mu \mathrm{g} / \mathrm{g}$ & $\mu \mathrm{g} / \mathrm{g}$ & $\mu g / g$ & $\mathrm{~kg}$ \\
\hline \multirow[t]{5}{*}{ IC.w.Cl- } & Sample J694 & 794 & \multirow{5}{*}{$\begin{array}{c}698 \\
\text { to } \\
2,020\end{array}$} & \multirow[t]{5}{*}{1,060} & & \multirow[t]{5}{*}{1,090} \\
\hline & Sample J695 & 698 & & & & \\
\hline & Sample J698 & 883 & & & & \\
\hline & Sample $\mathrm{J} 702$ & 2,020 & & & & \\
\hline & Sample $\mathrm{J} 703$ & 1,110 & & & & \\
\hline
\end{tabular}


Table A-2. Tank 241-C-110 Analytical Data: Cyanide

\begin{tabular}{|c|c|c|c|c|c|c|}
\hline $\begin{array}{c}\text { Arialyte } \\
\therefore\end{array}$ & $\begin{array}{c}\text { Laboratory } \\
\text { Sample } \\
\text { Idetntification }\end{array}$ & $\begin{array}{l}\text { Analytical } \\
\because \text { Data } \\
\because \text { Result }\end{array}$ & $\begin{array}{c}\text { Range : } \\
\text { of }: \\
\text { Values : }\end{array}$ & $\begin{array}{l}\text { Weighted } \\
\text { Meant } \\
\text { Standard } \\
\text { Error }\end{array}$ & $\begin{array}{c}\text { Evaluated } \\
\text { Data } \\
\text { Result }\end{array}$ & $\begin{array}{l}\text { Projected } \\
\text { Invientory } \\
\end{array}$ \\
\hline Anion (Liquid) & & $\mu \mathrm{g} / \mathrm{mL}$ & $\mu \mathrm{g} / \mathrm{mL}$ & $\mu \mathrm{g} / \mathrm{mL}$ & $\mu \mathrm{g} / \mathrm{mL}$ & $\mathrm{kg}$ \\
\hline $\begin{array}{r}\text { Spectrophot. } \\
\text { CN }^{-}\end{array}$ & Sample $J 799$ & 2.62 & N/A & - & 2.62 & 0.0694 \\
\hline Anion (Solid) & & $\mu \mathrm{g} / \mathrm{g}$ & $\mu \mathrm{g} / \mathrm{g}$ & $\mu g / g$ & $\mu g / g$ & $\mathrm{~kg}$ \\
\hline \multirow{5}{*}{$\begin{array}{r}\text { Spectrophot. } \\
\mathrm{CN}^{-}\end{array}$} & Sample J674 & $<5.00$ & \multirow[t]{5}{*}{ N/A } & \multirow[t]{5}{*}{--} & \multirow[t]{5}{*}{$<5.00$} & \multirow[t]{5}{*}{$<5.13$} \\
\hline & Sample J678 & $<5.00$ & & & & \\
\hline & Sample J682 & $<5.00$ & & & & \\
\hline & Sample J687 & $<3.23$ & & & & \\
\hline & Sample J688 & $<3.23$ & & & & \\
\hline
\end{tabular}

Table A-2. Tank 241-C-110 Analytical Data: Fluoride

\begin{tabular}{|c|c|c|c|c|c|c|}
\hline Analyte & $\begin{array}{l}\text { Laboratory } \\
\text { Sample } \\
\text { Identification }\end{array}$ & $\begin{array}{c}\text { Analytical } \\
\text { Data } \\
\text { Result }\end{array}$ & $\begin{array}{c}\text { Range } \\
\text { of } \\
\text { Values }\end{array}$ & $\begin{array}{l}\text { Weighted } \\
\text { Mean/ } \\
\text { Standard } \\
\text { Error }\end{array}$ & $\begin{array}{c}\text { Evaluated } \\
\text { Data } \\
\text { Result }\end{array}$ & $\begin{array}{l}\text { Projected } \\
\text { Inventory }\end{array}$ \\
\hline Anion (Liquid) & & $\mu \mathrm{g} / \mathrm{mL}$ & $\mu \mathrm{g} / \mathrm{mL}$ & $\mu \mathrm{g} / \mathrm{mL}$ & $\mu \mathrm{g} / \mathrm{mL}$ & $\mathrm{kg}$ \\
\hline \multirow[t]{4}{*}{ IC.d.F- } & Sample J800 & 809 & \multirow{4}{*}{$\begin{array}{l}214 \\
\text { to } \\
809\end{array}$} & \multirow[t]{4}{*}{--} & \multirow[t]{4}{*}{516} & \multirow[t]{4}{*}{13.7} \\
\hline & Sample J783 & 214 & & & & \\
\hline & Sample J778 & $(609)$ & & & & \\
\hline & Sample $J 775$ & 431 & & & & \\
\hline Anion (Solid) & & $\mu \mathrm{g} / \mathrm{g}$ & $\mu g / g$ & $\mu \mathrm{g} / \mathrm{g}$ & $\mu \mathrm{g} / \mathrm{g}$ & $\mathrm{kg}$ \\
\hline \multirow[t]{5}{*}{ IC.W.F* } & Sample J694 & 8,640 & \multirow{5}{*}{$\begin{array}{l}4,600 \\
\text { to } \\
9,260\end{array}$} & \multirow[t]{5}{*}{7.630} & & \multirow[t]{5}{*}{7,830} \\
\hline & Sample J695 & 9,260 & & & & \\
\hline & Sample J698 & 8,200 & & & & \\
\hline & Sample J702 & 6,900 & & & & \\
\hline & Sample J703 & 4,600 & & & & \\
\hline
\end{tabular}


Table A-2. Tank 241-C-110 Analytical Data: Nitrate

\begin{tabular}{|c|c|c|c|c|c|c|}
\hline Analyte & $\begin{array}{l}\text { Laboratory } \\
\text { Sample } \\
\text { Identification }\end{array}$ & $\begin{array}{c}\text { Analytical } \\
\text { Data } \\
\text { Result }\end{array}$ & $\begin{array}{c}\text { Range } \\
\text { of } \\
\text { Values }\end{array}$ & $\begin{array}{c}\text { Weighted } \\
\text { Mean/ } \\
\text { Standard } \\
\text { Error }\end{array}$ & $\begin{array}{c}\text { Evaluated } \\
\text { Data } \\
\text { Result }\end{array}$ & $\begin{array}{l}\text { Projected } \\
\text { Inventory }\end{array}$ \\
\hline Anion (Liquid) & & $\mu \mathrm{g} / \mathrm{mL}$ & $\mu \mathrm{g} / \mathrm{mL}$ & $\mu \mathrm{g} / \mathrm{mL}$ & $\mu \mathrm{g} / \mathrm{mL}$ & $\mathrm{kg}$ \\
\hline \multirow[t]{4}{*}{ IC.d. $\mathrm{NO}_{3}^{-}$} & Sample J800 & 60,300 & \multirow{4}{*}{$\begin{array}{c}21,000 \\
\text { to } \\
182,000\end{array}$} & \multirow[t]{4}{*}{---} & \multirow[t]{4}{*}{90,800} & \multirow[t]{4}{*}{2,410} \\
\hline & Sample $J 783$ & 21,000 & & & & \\
\hline & Sample J788 & 100,000 & & & & \\
\hline & Sample $J 775$ & 182,000 & & & & \\
\hline Anion (Solid) & & $\mu \mathrm{g} / \mathrm{g}$ & $\mu \mathrm{g} / \mathrm{g}$ & $\mu \mathrm{g} / \mathrm{g}$ & $\mu \mathrm{g} / \mathrm{g}$ & $\mathrm{kg}$ \\
\hline \multirow[t]{5}{*}{ IC.W. $\mathrm{NO}_{3}^{-}$} & Sample $J 694$ & 96,400 & \multirow{5}{*}{$\begin{array}{c}94,000 \\
\text { to } \\
121,000\end{array}$} & \multirow[t]{2}{*}{110,000} & & \multirow[t]{5}{*}{114,000} \\
\hline & Sample J695 & 94,000 & & & & \\
\hline & Sample J698 & 116,000 & & \multirow[t]{3}{*}{7,530} & & \\
\hline & Sample J702 & 121,000 & & & & \\
\hline & Sample J703 & 118,000 & & & . & \\
\hline
\end{tabular}

Table A-2. Tank 241-C-110 Analytical Data: Nitrite

\begin{tabular}{|c|c|c|c|c|c|c|}
\hline Analyte & $\begin{array}{c}\text { Laboratory } \\
\text { Sample } \\
\text { Identification }\end{array}$ & $\begin{array}{c}\text { Analytical } \\
\text { Data } \\
\text { Result }\end{array}$ & $\begin{array}{c}\text { Range } \\
\text { of } \\
\text { Values }\end{array}$ & $\begin{array}{c}\text { Weighted } \\
\text { Mean/ } \\
\text { Standard } \\
\text { Error }\end{array}$ & $\begin{array}{c}\text { Evaluated } \\
\text { Data } \\
\text { Result }\end{array}$ & $\begin{array}{l}\text { Projected } \\
\text { Inventory }\end{array}$ \\
\hline Anion (Liquid) & & $\mu \mathrm{g} / \mathrm{mL}$ & $\mu \mathrm{g} / \mathrm{mL}$ & $\mu \mathrm{g} / \mathrm{mL}$ & $\mu \mathrm{g} / \mathrm{mL}$ & $\mathrm{kg}$ \\
\hline \multirow[t]{4}{*}{ IC.d. $\mathrm{NO}_{2}^{-}$} & Sample J800 & 4,600 & \multirow{4}{*}{$\begin{array}{c}1,680 \\
\text { to } \\
18,700\end{array}$} & \multirow[t]{4}{*}{---} & \multirow[t]{4}{*}{7,850} & \multirow[t]{4}{*}{208} \\
\hline & Sample J783 & 1,680 & & & & \\
\hline & Sample $J 778$ & 6,430 & & & & \\
\hline & Sample $J 775$ & 18,700 & & & & \\
\hline Anion (Solid) & & $\mu \mathrm{g} / \mathrm{g}$ & $\mu \mathrm{g} / \mathrm{g}$ & $\mu \mathrm{g} / \mathrm{g}$ & $\mu g / g$ & $\mathrm{~kg}$ \\
\hline \multirow[t]{5}{*}{ IC.w. $\mathrm{NO}_{2}$} & Sample J694 & 2,710 & \multirow{5}{*}{$\begin{array}{c}2,710 \\
\text { to } \\
12,900\end{array}$} & \multirow[t]{2}{*}{6,890} & & \multirow[t]{5}{*}{7,070} \\
\hline & Sample J695 & 2,820 & & & & \\
\hline & Sample J698 & 5,090 & & \multirow[t]{3}{*}{3,040} & & \\
\hline & Sample J702 & 12,900 & & & & \\
\hline & Sample J703 & 12,800 & & & & \\
\hline
\end{tabular}


Table A-2. Tank 241-C-110 Analytical Data: Phosphate

\begin{tabular}{|c|c|c|c|c|c|c|}
\hline Analyte & $\begin{array}{l}\text { Laboratory } \\
\text { Sample } \\
\text { Identification }\end{array}$ & $\begin{array}{c}\text { Analytical } \\
\text { Data } \\
\text { Result }\end{array}$ & $\begin{array}{l}\text { Range } \\
\text { of } \\
\text { Values }\end{array}$ & $\begin{array}{c}\text { Weighted } \\
\text { Mean/ } \\
\text { Standard } \\
\text { Error }\end{array}$ & $\begin{array}{c}\text { Evaluated } \\
\text { Data } \\
\text { Result }\end{array}$ & $\begin{array}{l}\text { Projected } \\
\text { Inventory }\end{array}$ \\
\hline Anion (Liquid) & & $\mu \mathrm{g} / \mathrm{mL}$ & $\mu \mathrm{g} / \mathrm{mL}$ & $\mu \mathrm{g} / \mathrm{mL}$ & $\mu \mathrm{g} / \mathrm{mL}$ & $\mathrm{kg}$ \\
\hline \multirow[t]{4}{*}{ Ic.d. $\mathrm{PO}_{4}^{-3}$} & Sample J800 & 4,610 & \multirow{4}{*}{$\begin{array}{c}2,030 \\
\text { to } \\
7,970\end{array}$} & \multirow[t]{4}{*}{--} & \multirow[t]{4}{*}{5,530} & \multirow[t]{4}{*}{147} \\
\hline & Sample J783 & 2,030 & & & & \\
\hline & Sample J778 & 7,520 & & & & \\
\hline & Sample J775 & 7,970 & & & & \\
\hline Anion (Solid) & & $\mu \mathrm{g} / \mathrm{g}$ & $\mu \mathrm{g} / \mathrm{g}$ & $\mu \mathrm{g} / \mathrm{g}$ & $\mu \mathrm{g} / \mathrm{g}$ & $\mathrm{kg}$ \\
\hline \multirow[t]{5}{*}{ IC. W. $\mathrm{PO}_{4}^{-3}$} & Sample J694 & 37,600 & \multirow{5}{*}{$\begin{array}{c}15,800 \\
\text { to } \\
37,600\end{array}$} & \multirow[t]{2}{*}{28,100} & & \multirow[t]{5}{*}{28,800} \\
\hline & Sample J695 & 45,400 & & & & \\
\hline & Sample J698 & 25,500 & & \multirow[t]{3}{*}{7,200} & & \\
\hline & Sample $J 702$ & 15,800 & & & & \\
\hline & Sample $\mathrm{J} 703$ & 19,200 & & & & \\
\hline
\end{tabular}

Table A-2. Tank 241-C-110 Analytical Data: Sulfate

\begin{tabular}{|c|c|c|c|c|c|c|}
\hline Analyte & $\begin{array}{l}\text { Laboratory } \\
\text { Sample } \\
\text { Identification }\end{array}$ & $\begin{array}{c}\text { Analytical } \\
\text { Data } \\
\text { Result }\end{array}$ & $\begin{array}{l}\text { Range } \\
\text { of } \\
\text { Values }\end{array}$ & $\begin{array}{l}\text { Weighted } \\
\text { Mean/ } \\
\text { Standard } \\
\text { Error }\end{array}$ & $\begin{array}{c}\text { Evaluated } \\
\text { Data } \\
\text { Result }\end{array}$ & $\begin{array}{l}\text { Projected } \\
\text { Inventory }\end{array}$ \\
\hline Anion (Liquid) & & $\mu \mathrm{g} / \mathrm{mL}$ & $\mu \mathrm{g} / \mathrm{mL}$ & $\mu \mathrm{g} / \mathrm{mL}$ & $\mu \mathrm{g} / \mathrm{mL}$ & $\mathrm{kg}$ \\
\hline \multirow[t]{4}{*}{ IC.d. $\mathrm{SO}_{4}^{-2}$} & Sample J800 & 7,320 & \multirow{4}{*}{$\begin{array}{c}4,810 \\
\text { to } \\
22,000\end{array}$} & \multirow[t]{4}{*}{---} & \multirow[t]{4}{*}{11,100} & \multirow[t]{4}{*}{294} \\
\hline & Sample J783 & 4,810 & & & & \\
\hline & Sample J778 & 10,200 & & & & \\
\hline & Sample J775 & 22,000 & & & & \\
\hline Anion (Solid) & & $\mu \mathrm{g} / \mathrm{g}$ & $\mu \mathrm{g} / \mathrm{g}$ & $\mu \mathrm{g} / \mathrm{g}$ & $\mu g / g$ & $\mathrm{~kg}$ \\
\hline \multirow[t]{5}{*}{ IC.w. $\mathrm{SO}_{4}^{-2}$} & Sample J694 & 11,100 & \multirow{5}{*}{$\begin{array}{c}10,800 \\
\text { to } \\
22,300\end{array}$} & \multirow[t]{2}{*}{14,800} & & \multirow[t]{5}{*}{15,200} \\
\hline & Sample J695 & 10,800 & & & & \\
\hline & Sample J698 & 12,900 & & \multirow[t]{3}{*}{2,990} & & \\
\hline & Sample J702 & 19,100 & & & & \\
\hline & Sample J703 & 22,300 & & & & \\
\hline
\end{tabular}


WHC-SD-WM-ER-367 REV 0

Table A-3. Tank 241-C-110 Analytical Data: Americium-241

\begin{tabular}{|c|c|c|c|c|c|c|}
\hline Analyte & $\begin{array}{l}\text { Laboratory } \\
\text { Sample } \\
\text { Identification }\end{array}$ & $\begin{array}{c}\text { Analytical } \\
\text { Data } \\
\text { Result }\end{array}$ & $\begin{array}{c}\text { Range } \\
\text { of } \\
\text { Values }\end{array}$ & $\begin{array}{l}\text { Weighted } \\
\text { Mean/ } \\
\text { Standard } \\
\text { Error }\end{array}$ & $\begin{array}{c}\text { Evaluated } \\
\text { Data } \\
\text { Result }\end{array}$ & $\begin{array}{l}\text { Projected } \\
\text { Inventory }\end{array}$ \\
\hline $\begin{array}{l}\text { Radionuclide } \\
\text { (Liquid) }\end{array}$ & & $\mu \mathrm{Ci} / \mathrm{mL}$ & $\mu \mathrm{Ci} / \mathrm{mL}$ & $\mu \mathrm{Ci} / \mathrm{mL}$ & $\mu \mathrm{Ci} / \mathrm{mL}$ & $\mathrm{Ci}$ \\
\hline \multirow[t]{4}{*}{ GEA. ${ }^{241} \mathrm{Am}$} & Sample J783 & $(<0.0344)$ & \multirow{4}{*}{$\begin{array}{c}<0.0116 \\
\text { to } \\
<0.0516\end{array}$} & \multirow[t]{4}{*}{---} & \multirow[t]{4}{*}{$<0.0516$} & \multirow[t]{4}{*}{$<1.37$} \\
\hline & Sample $J 778$ & $(<0.0286)$ & & & & \\
\hline & Sample J775 & $(<0.0516)$ & & & & \\
\hline & Sample J800 & $<0.0116$ & & & & \\
\hline $\begin{array}{r}\text { Alpha Spec. } \\
{ }^{241} \text { Am }\end{array}$ & Sample J800 & (1.57E-05) & N/A & --- & $\cdots$ & --- \\
\hline $\begin{array}{l}\text { Radionuclide } \\
\text { (Solid) }\end{array}$ & & $\mu \mathrm{Ci} / \mathrm{g}$ & $\mu \mathrm{Ci} / \mathrm{g}$ & $\mu \mathrm{Ci} / \mathrm{g}$ & $\mu \mathrm{Ci} / \mathrm{g}$ & $\mathrm{Ci}$ \\
\hline \multirow[t]{5}{*}{ GEA. ${ }^{241} \mathrm{Am}$} & Sample J715 & $1<0.2801$ & \multirow[t]{5}{*}{ N/A } & \multirow[t]{5}{*}{$\cdots$} & \multirow[t]{5}{*}{$<0.280$} & \multirow[t]{14}{*}{$<287$} \\
\hline & Sample J716 & $(<0.266)$ & & & & \\
\hline & Sample J719 & $<0.203$ & & & & \\
\hline & Sample J723 & $<0.220$ & & & & \\
\hline & Sample J724 & $<0.216$ & & & & \\
\hline \multirow{4}{*}{$\begin{array}{r}\text { GEA. }{ }^{241} \text { Am } \\
\text { Segment } \\
\text { Sample }\end{array}$} & Sample J647 & $(<0.260)$ & \multirow[t]{4}{*}{ N/A } & \multirow[t]{4}{*}{$\cdots$} & \multirow[t]{4}{*}{$\cdots$} & \\
\hline & Sample J649 & $1<0.250)$ & & & & \\
\hline & Sample J658 & $(<0.175)$ & & & & \\
\hline & Sample J656 & $(<0.176)$ & & & & \\
\hline \multirow{5}{*}{$\begin{array}{r}\text { Alpha Spec. } \\
{ }^{241} \mathrm{Am}\end{array}$} & Sample $J 715$ & $(0.00522)$ & \multirow{5}{*}{$\begin{array}{l}0.00454 \\
\text { to } \\
0.00522\end{array}$} & \multirow[t]{5}{*}{0.0050} & \multirow[t]{5}{*}{$\cdots$} & \\
\hline & Sample $J 716$ & $(0.00454)$ & & & & \\
\hline & Sample J719 & $<0.00563$ & & & & \\
\hline & Sample J723 & $<0.00755$ & & & & \\
\hline & Sample J724 & $<0.00801$ & & & & \\
\hline
\end{tabular}


Table A-3. Tank 241-C-110 Analytical Data: Carbon-14

\begin{tabular}{|c|c|c|c|c|c|c|}
\hline Analyte & $\begin{array}{r}\text { Laboratiory } \\
\text { Sample } \\
\text { Identification }\end{array}$ & $\begin{array}{c}\because \text { Analytical } \\
\therefore \text { Data } \\
\therefore \text { Result }\end{array}$ & $\begin{array}{c}\text { Range } \\
\text { of } \\
\text { Values }\end{array}$ & $\begin{array}{l}\text { Weighted } \\
\text { Meanl } \\
\text { Standard } \\
\therefore \text { Errö }\end{array}$ & $\begin{array}{c}\text { Evaluated } \\
\text { Data } \\
\text { Result }\end{array}$ & $\begin{array}{l}\text { Projected } \\
\text { Inventory }\end{array}$ \\
\hline Radionuclide & & $\mu \mathrm{Ci} / \mathrm{mL}$ & $\mu \mathrm{Ci} / \mathrm{mL}$ & $\mu \mathrm{Ci} / \mathrm{mL}$ & $\mu \mathrm{Ci} / \mathrm{mL}$ & $\mathrm{Ci}$ \\
\hline $\begin{array}{l}\text { LSC. }{ }^{14} \mathrm{C} \\
\text { (Liquid) }\end{array}$ & Sample J800 & $(1.99 E-04)$ & N/A & -- & 1.99E-04 & 0.00527 \\
\hline Radionuclide & & $\mu \mathrm{Ci} / \mathrm{g}$ & $\mu \mathrm{Ci} / \mathrm{g}$ & $\mu \mathrm{Ci} / \mathrm{g}$ & $\mu \mathrm{Ci} / \mathrm{g}$ & $\mathrm{Ci}$ \\
\hline \multirow{5}{*}{$\begin{array}{r}\text { LSC. }{ }^{14} \mathrm{C} \\
\text { (Solid) }\end{array}$} & Sample $\mathrm{J702}$ & (6.02E-04) & \multirow{5}{*}{$\begin{array}{c}<6.14 \mathrm{E}-05 \\
\text { to } \\
6.63 \mathrm{E}-04 \\
.\end{array}$} & \multirow[t]{5}{*}{$4.59 E-04$} & \multirow[t]{5}{*}{$\cdots$} & \multirow[t]{5}{*}{0.471} \\
\hline & Sample J694 & (2.39E-04) & & & & \\
\hline & Sample J695 & (2.87E-04) & & & & \\
\hline & Sample J698 & $(<6.14 \mathrm{E}-05)$ & & & & \\
\hline & Sample J703 & (6.63E-04) & & & & \\
\hline
\end{tabular}

Table A-3. Tank 241-C-110 Analytical Data: Cesium-137

\begin{tabular}{|c|c|c|c|c|c|c|}
\hline Analyte & $\begin{array}{l}\text { Laboratory } \\
\text { Sample } \\
\text { Identification }\end{array}$ & $\begin{array}{c}\text { Analytical } \\
\text { Data } \\
\text { Result }\end{array}$ & $\begin{array}{c}\text { Range } \\
\text { of } \\
\text { Values }\end{array}$ & $\begin{array}{l}\text { Weighted } \\
\text { Mean/ } \\
\text { Standard } \\
\text { Error }\end{array}$ & $\begin{array}{c}\text { Evaluated } \\
\text { Data } \\
\text { Result }\end{array}$ & $\begin{array}{l}\text { Projected } \\
\text { Inventory }\end{array}$ \\
\hline $\begin{array}{l}\text { Radionuclide } \\
\text { (Liquid) }\end{array}$ & & $\mu \mathrm{Ci} / \mathrm{mL}$ & $\mu \mathrm{Ci} / \mathrm{mL}$ & $\mu \mathrm{Ci} / \mathrm{mL}$ & $\mu \mathrm{Ci} / \mathrm{mL}$ & $\mathrm{Ci}$ \\
\hline \multirow[t]{4}{*}{ GEA. ${ }^{137} \mathrm{Cs}$} & Sample J783 & $(0.841)$ & \multirow{4}{*}{$\begin{array}{c}0.841 \\
\text { to } \\
20.3\end{array}$} & \multirow[t]{4}{*}{---} & \multirow[t]{4}{*}{7.98} & \multirow[t]{4}{*}{211} \\
\hline & Sample J778 & $(5.94)$ & & & & \\
\hline & Sample J775 & $(20.3)$ & & & & \\
\hline & Sample J800 & 4.85 & & & & \\
\hline $\begin{array}{l}\text { Radionuclide } \\
\text { (Solid) }\end{array}$ & & $\mu \mathrm{Ci} / \mathrm{g}$ & $\mu \mathrm{Ci} / \mathrm{g}$ & $\mu \mathrm{Ci} / \mathrm{g}$ & $\mu \mathrm{Ci} / \mathrm{g}$ & $\mathrm{Ci}$ \\
\hline \multirow[t]{5}{*}{ GEA. ${ }^{137} \mathrm{Cs}$} & Sample J715 & $(15.3)$ & \multirow{5}{*}{$\begin{array}{l}14.6 \\
\text { to } \\
24.1\end{array}$} & \multirow[t]{5}{*}{19.5} & \multirow[t]{5}{*}{--} & \multirow[t]{9}{*}{20,000} \\
\hline & Sample J716 & $(14.6)$ & & & & \\
\hline & Sample J719 & 19.8 & & & & \\
\hline & Sample J723 & 23.4 & & & & \\
\hline & Sample $J 724$ & 24.1 & & & & \\
\hline \multirow{4}{*}{$\begin{array}{r}\text { GEA. }{ }^{137} \mathrm{Cs} \\
\text { Segment } \\
\text { Sample }\end{array}$} & Sample J647 & $(14.2)$ & \multirow[t]{4}{*}{$\cdots$} & \multirow[t]{4}{*}{--} & \multirow[t]{4}{*}{--} & \\
\hline & Sample J649 & $(14.1)$ & & & & \\
\hline & Sample J658 & $(21.3)$ & & & & \\
\hline & Sample J656 & $(20.5)$ & & & & \\
\hline
\end{tabular}


Table A-3. Tank 241-C-110 Analytical Data: Cobalt-60

\begin{tabular}{|c|c|c|c|c|c|c|}
\hline Analyte & $\begin{array}{l}\text { Laboratory } \\
\text { Sample } \\
\text { Identification }\end{array}$ & $\begin{array}{c}\text { Analytical } \\
\text { Data } \\
\text { - Result }\end{array}$ & $\begin{array}{c}\text { Range } \\
\text { of } \\
\text { Vatues }\end{array}$ & $\begin{array}{l}\text { Weighted } \\
\text { Mean/ } \\
\text { Standard } \\
\text { Error }\end{array}$ & $\begin{array}{c}\text { Evaluated } \\
\text { Data } \\
\text { Result }\end{array}$ & $\begin{array}{l}\text { Projected } \\
\text { Inventory }\end{array}$ \\
\hline Radionuclide & & $\mu \mathrm{Ci} / \mathrm{mL}$ & $\mu \mathrm{Ci} / \mathrm{mL}$ & $\mu \mathrm{Ci} / \mathrm{mL}$ & $\mu \mathrm{Ci} / \mathrm{mL}$ & $\mathrm{Ci}$ \\
\hline \multirow{4}{*}{$\begin{array}{r}\text { GEA. }{ }^{60} \text { Co } \\
\text { (Liquid) }\end{array}$} & Sample J783 & $(<0.00720)$ & \multirow{4}{*}{$\begin{array}{c}<8.31 \mathrm{E}-04 \\
\text { to } \\
<0.00720\end{array}$} & \multirow[t]{4}{*}{--} & \multirow[t]{4}{*}{$<0.00720$} & \multirow[t]{4}{*}{$<0.191$} \\
\hline & Sample J778 & $|<0.00142|$ & & & & \\
\hline & Sample J775 & $\mid<0.00180)$ & & & & \\
\hline & Sample J800 & $<8.31 \mathrm{E}-04$ & & & & \\
\hline Radionuclide & & $\mu \mathrm{Ci} / \mathrm{g}$ & $\mu \mathrm{Ci} / \mathrm{g}$ & $\mu \mathrm{Ci} / \mathrm{g}$ & $\mu \mathrm{Ci} / \mathrm{g}$ & $\mathrm{Ci}$ \\
\hline \multirow{5}{*}{$\begin{array}{r}\text { GEA. }{ }^{60} \text { Co } \\
\text { (Solid) }\end{array}$} & Sample J715 & $1<0.0310)$ & \multirow{5}{*}{$\begin{array}{c}<0.0276 \\
\text { to } \\
<0.0433\end{array}$} & \multirow[t]{5}{*}{$\cdots$} & \multirow[t]{5}{*}{$<0.0433$} & \multirow[t]{9}{*}{$<44.5$} \\
\hline & Sample J716 & $1<0.02761$ & & & & \\
\hline & Sample J719 & $<0.0416$ & & & & \\
\hline & Sample J723 & $<0.0433$ & & & & \\
\hline & Sample J724 & $<0.0415$ & & & & \\
\hline \multirow[t]{4}{*}{ GEA $\cdot{ }^{60} \mathrm{Co}$} & Sample J647 & $1<0.03001$ & \multirow{4}{*}{$\begin{array}{c}<0.00760 \\
\text { to } \\
<0.0300\end{array}$} & \multirow[t]{4}{*}{---} & \multirow[t]{4}{*}{--} & \\
\hline & Sample J649 & $1<0.02001$ & & & & \\
\hline & Sample J658 & $(<0.00760)$ & & & & \\
\hline & Sample J656 & $1<0.01001$ & & & & \\
\hline
\end{tabular}


Table A-3. Tank 241-C-110 Analytical Data: Europium-154

\begin{tabular}{|c|c|c|c|c|c|c|}
\hline Analyte & $\begin{array}{c}\text { Laboratory } \\
\text { Sample } \\
\text { Identification. }\end{array}$ & $\begin{array}{c}\text { Analytical } \\
\text { Data } \\
\text { Result }\end{array}$ & $\begin{array}{c}\text { Range } \\
\text { of } \\
\text { Values }\end{array}$ & $\begin{array}{c}\text { Weighted } \\
\text { Mean/ } \\
\text { Standard } \\
\text { Error }\end{array}$ & $\begin{array}{c}\text { Evaluated } \\
\text { Data } \\
\text { Result }\end{array}$ & $\begin{array}{l}\text { Projected } \\
\text { Inventory }\end{array}$ \\
\hline Radionuclide & & $\mu \mathrm{Ci} / \mathrm{mL}$ & $\mu \mathrm{Ci} / \mathrm{mL}$ & $\mu \mathrm{Ci} / \mathrm{mL}$ & $\mu \mathrm{Ci} / \mathrm{ml}$ & $\mathrm{Ci}$ \\
\hline \multirow{4}{*}{$\begin{array}{r}\text { GEA. }{ }^{154} \text { Eu } \\
\text { (Liquid) }\end{array}$} & Sample J783 & $(<0.0192)$ & \multirow{4}{*}{$\begin{array}{c}<0.00229 \\
\text { to } \\
<0.0192\end{array}$} & \multirow[t]{4}{*}{--} & \multirow[t]{4}{*}{$<0.0192$} & \multirow[t]{4}{*}{$<0.509$} \\
\hline & Sample J778 & $(<0.00551)$ & & & & \\
\hline & Sample J775 & $(<0.00607)$ & & & & \\
\hline & Sample J800 & $(<0.00229)$ & & & & \\
\hline Radionuclide & & $\mu \mathrm{Ci} / \mathrm{g}$ & $\mu \mathrm{Ci} / \mathrm{g}$ & $\mu \mathrm{Ci} / \mathrm{g}$ & $\mu \mathrm{Ci} / \mathrm{g}$ & $\mathrm{Ci}$ \\
\hline \multirow{5}{*}{$\begin{array}{r}\text { GEA. }{ }^{154} \mathrm{Eu} \\
\text { (Solid) }\end{array}$} & Sample $J 715$ & $(<0.0678)$ & \multirow{5}{*}{$\begin{array}{c}<0.00678 \\
\text { to } \\
<0.120\end{array}$} & \multirow[t]{5}{*}{--} & \multirow[t]{5}{*}{$<0.120$} & \multirow[t]{9}{*}{$<123$} \\
\hline & Sample $\mathbf{J 7 1 6}$ & $(<0.0720)$ & & & & \\
\hline & Sample J719 & $<0.113$ & & & & \\
\hline & Sample J723 & $<0.119$ & & & & \\
\hline & Sample J724 & $<0.120$ & & & & \\
\hline \multirow{4}{*}{$\begin{array}{r}\text { GEA. }{ }^{154} \text { Eu } \\
\text { Segment } \\
\text { Sample }\end{array}$} & Sample J647 & $(<0.0900)$ & \multirow[t]{4}{*}{$\cdots$} & \multirow[t]{4}{*}{---} & \multirow[t]{4}{*}{--} & \\
\hline & Sample J649 & $(<0.0700)$ & & & & \\
\hline & Sample J658 & $(<0.0290)$ & & & & \\
\hline & Sample J656 & $(<0.0350)$ & & & & \\
\hline
\end{tabular}


Table A-3. Tank 241-C-110 Analytical Data: Europium-155

\begin{tabular}{|c|c|c|c|c|c|c|}
\hline Analyte & $\begin{array}{l}\text { Laboratory } \\
\text { Sample } \\
\text { Identification }\end{array}$ & $\begin{array}{c}\text { Analytical } \\
\text { Data } \\
\text { Result }\end{array}$ & $\begin{array}{c}\text { Range } \\
\text { of } \\
\text { Values }\end{array}$ & $\begin{array}{c}\text { Weighted } \\
\text { Mean/ } \\
\text { Standard } \\
\text { Error }\end{array}$ & $\begin{array}{c}\text { Evaluated } \\
\text { Data } \\
\text { Result }\end{array}$ & $\begin{array}{l}\text { Projected } \\
\text { Inventory }\end{array}$ \\
\hline Radionuclide & & $\mu \mathrm{Ci} / \mathrm{mL}$ & $\mu \mathrm{Ci} / \mathrm{mL}$ & $\mu \mathrm{Ci} / \mathrm{mL}$ & $\mu \mathrm{Ci} / \mathrm{ml}$ & $\mathrm{Ci}$ \\
\hline \multirow{4}{*}{$\begin{array}{l}\text { GEA. }{ }^{155} \text { Eu } \\
\text { (Liquid) }\end{array}$} & Sample J783 & $(<0.0146)$ & \multirow{4}{*}{$\begin{array}{c}<0.00576 \\
\text { to } \\
<0.0216\end{array}$} & \multirow[t]{4}{*}{-} & \multirow[t]{4}{*}{$<0.0216$} & \multirow[t]{4}{*}{$<0.572$} \\
\hline & Sample J778 & $(<0.0118)$ & & & & \\
\hline & Sample $\mathrm{J} 775$ & $(<0.0216)$ & & & & \\
\hline & Sample J800 & $<0.00576$ & & & & \\
\hline Radionuclide & & $\mu \mathrm{Ci} / \mathrm{g}$ & $\mu \mathrm{Ci} / \mathrm{g}$ & $\mu \mathrm{Ci} / \mathrm{g}$ & $\mu \mathrm{Ci} / \mathrm{g}$ & $\mathrm{Ci}$ \\
\hline \multirow{5}{*}{$\begin{array}{r}\text { GEA. }{ }^{155} \mathrm{Eu} \\
\text { (Solid) }\end{array}$} & Sample J715 & $(<0.122)$ & \multirow{5}{*}{$\begin{array}{l}<0.103 \\
\text { to } \\
<0.122\end{array}$} & \multirow[t]{5}{*}{---} & \multirow[t]{5}{*}{$<0.122$} & \multirow[t]{9}{*}{$<125$} \\
\hline & Sample J716 & $(<0.122)$ & & & & \\
\hline & Sample J719 & $<0.103$ & & & & \\
\hline & Sample $J 723$ & $<0.108$ & & & & \\
\hline & Sample J724 & $<0.109$ & & & & \\
\hline \multirow{4}{*}{$\begin{array}{r}\text { GEA. }{ }^{155} \text { Eu } \\
\text { Segment } \\
\text { Sample }\end{array}$} & Sample J647 & $1<0.120\}$ & \multirow{4}{*}{$\begin{array}{c}<0.0780 \\
\text { to } \\
<0.120\end{array}$} & \multirow[t]{4}{*}{--} & \multirow[t]{4}{*}{--} & \\
\hline & Sample J649 & $(<0.110)$ & & & & \\
\hline & Sample J658 & $(<0.0780)$ & & & & \\
\hline & Sample J656 & $1<0.08001$ & & & & \\
\hline
\end{tabular}


Table A-3. Tank 241-C-110 Analytical Data: lodine-129

\begin{tabular}{|c|c|c|c|c|c|c|}
\hline $\begin{array}{cc} & \\
& \\
& \text { Analyte } \\
\because & \cdots\end{array}$ & $\begin{array}{c}\because \text { Laboratory } \\
\text { Sample } \\
\text { Identification }\end{array}$ & $\begin{array}{c}\text { Analytical } \\
\text { Data } \\
\therefore \text { Result }\end{array}$ & $\begin{array}{c}\text { Range } \\
\text { of } \\
\text { Values }\end{array}$ & $\begin{array}{l}\text { Weighted } \\
\text { Meanl } \\
\text { Standard } \\
\therefore \text { Errör }\end{array}$ & $\begin{array}{c}\text { Evaluated } \\
\text { Data } \\
\text { Restult }\end{array}$ & $\begin{array}{l}\text { Projected } \\
\text { Inventory }\end{array}$ \\
\hline $\begin{array}{l}\text { Radionuclide } \\
\text { (Liquid) }\end{array}$ & & $\mu \mathrm{Ci} / \mathrm{mL}$ & $\mu \mathrm{Ci} / \mathrm{mL}$ & $\mu \mathrm{Ci} / \mathrm{mL}$ & $\mu \mathrm{Ci} / \mathrm{mL}$ & $\mathrm{Ci}$ \\
\hline $\begin{array}{l}\text { Low Energy } \\
\text { Gamma. }^{129}\end{array}$ & Sample J800 & $(<2.38 \mathrm{E}-05)$ & N/A & - & $<2.38 E-05$ & $<0.0211$ \\
\hline $\begin{array}{l}\text { Radionuclide } \\
\text { (Soild) }\end{array}$ & & $\mu \mathrm{Ci} / \mathrm{g}$ & $\mu \mathrm{Ci} / \mathrm{g}$ & $\mu \mathrm{Ci} / \mathrm{g}$ & $\mu \mathrm{Ci} / \mathrm{g}$ & $\mathrm{Ci}$ \\
\hline \multirow[t]{5}{*}{ GEA. ${ }^{129} 1$} & Sample J715 & $(<0.0154)$ & \multirow[t]{5}{*}{ N/A } & \multirow[t]{5}{*}{--} & \multirow[t]{5}{*}{$<0.0250$} & \multirow[t]{5}{*}{$<25.7$} \\
\hline & Sample $J 716$ & $(<0.0186)$ & & & & \\
\hline & Sample J719 & $1<0.0191)$ & & & & \\
\hline & Sample J723 & $(<0.0130)$ & & & & \\
\hline & Sample J724 & $|<0.0250|$ & & & & \\
\hline
\end{tabular}


Table A-3. Tank 241-C-110 Analytical Data: Neptunium-237

\begin{tabular}{|c|c|c|c|c|c|c|}
\hline Analyte & $\begin{array}{l}\text { Laboratory } \\
\text { Sample } \\
\text { Identification }\end{array}$ & $\begin{array}{c}\text { Analytical } \\
\text { Data } \\
\text { Result }\end{array}$ & $\begin{array}{l}\text { Range } \\
\text { Values }\end{array}$ & $\begin{array}{l}\text { Weighted } \\
\text { Meanl. } \\
\text { Standard } \\
\text { Error }\end{array}$ & $\begin{array}{l}\text { Evaluated } \\
\text { Data } \\
\text { Result }\end{array}$ & $\begin{array}{l}\text { Projected } \\
\text { Inventory }\end{array}$ \\
\hline $\begin{array}{l}\text { Radionuclide } \\
\text { (Liquid) }\end{array}$ & & $\mu \mathrm{Ci} / \mathrm{mL}$ & $\mu \mathrm{Ci} / \mathrm{mL}$ & $\mu \mathrm{Ci} / \mathrm{mL}$ & $\mu \mathrm{Ci} / \mathrm{mL}$ & $\mathrm{Ci}$ \\
\hline APC. ${ }^{237} \mathrm{~Np}$ & Sample 3800 & $(<6.49 E-05)$ & N/A & $\cdots$ & $<6.49 E-05$ & 0.0574 \\
\hline \multirow[t]{6}{*}{$\begin{array}{l}\text { Radionuclide } \\
\text { (Solid) }\end{array}$} & & $\mu \mathrm{Ci} / \mathrm{g}$ & $\mu \mathrm{Ci} / \mathrm{g}$ & $\mu \mathrm{Ci} / \mathrm{g}$ & $\mu \mathrm{Ci} / \mathrm{g}$ & $\mathrm{Ci}$ \\
\hline & Sample J715 & $1<0.03241$ & \multirow{5}{*}{$\begin{array}{c}<0.0323 \\
\text { to } \\
<0.0541\end{array}$} & \multirow[t]{5}{*}{---} & \multirow[t]{5}{*}{$<0.0541$} & \multirow[t]{5}{*}{$<55.6$} \\
\hline & Sample J716 & $1<0.03231$ & & & & \\
\hline & Sample J719 & $1<0.0541)$ & & & & \\
\hline & Sample $\mathrm{J} 723$ & $(<0.0323)$ & & & & \\
\hline & Sample J724 & $(<0.0324)$ & & & & \\
\hline
\end{tabular}

Table A-3. Tank 241-C-110 Analytical Data: Plutonium-238

\begin{tabular}{|c|c|c|c|c|c|c|}
\hline Analyte & $\begin{array}{l}\text { Laboratory } \\
\text { Sample } \\
\text { Identification }\end{array}$ & $\begin{array}{c}\text { Analytical } \\
\text { Data } \\
\text { Result }\end{array}$ & $\begin{array}{c}\text { Range } \\
\text { of } \\
\text { Values }\end{array}$ & $\begin{array}{l}\text { Weighted } \\
\text { Mean/ } \\
\text { Standard } \\
\text { Error }\end{array}$ & $\begin{array}{c}\text { Evaluated } \\
\text { Data } \\
\text { Result }\end{array}$ & $\begin{array}{l}\text { Projected } \\
\text { Inventory }\end{array}$ \\
\hline Radionuclide & & $\mu \mathrm{Ci} / \mathrm{mL}$ & $\mu \mathrm{Ci} / \mathrm{mL}$ & $\mu \mathrm{Ci} / \mathrm{mL}$ & $\mu \mathrm{Ci} / \mathrm{mL}$ & $\mathrm{Ci}$ \\
\hline $\begin{array}{r}\text { GEA. }{ }^{238} \mathrm{Pu} \\
\text { (Liquid) }\end{array}$ & Sample J800 & $(<9.00 \mathrm{E}-06)$ & N/A & --- & $<9.00$ E-06 & $<1.59 \mathrm{E}-04$ \\
\hline Radionuclide & & $\mu \mathrm{Ci} / \mathrm{g}$ & $\mu \mathrm{Ci} / \mathrm{g}$ & $\mu \mathrm{Ci} / \mathrm{g}$ & $\mu \mathrm{Ci} / \mathrm{g}$ & $\mathrm{Ci}$ \\
\hline \multirow{5}{*}{$\begin{array}{r}\text { GEA. }{ }^{238} \mathrm{Pu} \\
\text { (Solid) }\end{array}$} & Sample J715 & $<0.00450$ & \multirow[t]{5}{*}{ N/A } & \multirow[t]{5}{*}{---} & \multirow[t]{5}{*}{$<0.00498$} & \multirow[t]{5}{*}{$<51.1$} \\
\hline & Sample J716 & $(<0.00448)$ & & & & \\
\hline & Sample J719 & $(<0.00225)$ & & & & \\
\hline & Sample J723 & $(<0.00498)$ & & & & \\
\hline & Sample J724 & $(<0.00450)$ & & & & \\
\hline
\end{tabular}


Table A-3. Tank 241-C-110 Analytical Data: Plutonium-239/240

\begin{tabular}{|c|c|c|c|c|c|c|}
\hline $\begin{array}{c}\text { Analyte } \because \\
\therefore \quad \therefore \quad \therefore\end{array}$ & $\begin{array}{l}\text { Laboratory } \\
\therefore \text { Sample } \\
\text { Identification }\end{array}$ & $\begin{array}{c}\text { Analytical } \\
\text { Data } \\
\text { Result }\end{array}$ & $\begin{array}{l}\text { Range } \\
\text { of } \\
\text { Values }\end{array}$ & $\begin{array}{l}\text { Weighted } \\
\text { Mean/ } \\
\text { Standard } \\
\text { Error }\end{array}$ & $\begin{array}{c}\text { Evaluated } \\
\text { Data } \\
\text { Result }\end{array}$ & $\begin{array}{c}\text { Projected } \\
\text { Inventory } \\
\vdots \\
\vdots\end{array}$ \\
\hline Radionuclide & & $\mu \mathrm{Ci} / \mathrm{mL}$ & $\mu \mathrm{Ci} / \mathrm{mL}$ & $\mu \mathrm{Ci} / \mathrm{mL}$ & $\mu \mathrm{Ci} / \mathrm{mL}$ & $\mathrm{Ci}$ \\
\hline $\begin{array}{r}\text { Alpha Spec. } \\
239 / 240 \mathrm{Pu} \\
\text { (Liquid) }\end{array}$ & Sample J800 & $(0.00176)$ & N/A & $\cdots$ & 0.00176 & 0.0466 \\
\hline Radionuclide & & $\mu \mathrm{Ci} / \mathrm{g}$ & $\mu \mathrm{Ci} / \mathrm{g}$ & $\mu \mathrm{Ci} / \mathrm{g}$ & $\mu \mathrm{Ci} / \mathrm{g}$ & $\mathrm{Ci}$ \\
\hline \multirow{5}{*}{$\begin{array}{r}\text { Alpha Spec. } \\
239 / 240 \mathrm{Pu} \\
\text { (Solid) }\end{array}$} & Sample J715 & $(0.00450)$ & \multirow{5}{*}{$\begin{array}{c}0.00450 \\
\text { to } \\
0.144\end{array}$} & \multirow[t]{5}{*}{0.0802} & \multirow[t]{5}{*}{--} & \multirow[t]{5}{*}{82.4} \\
\hline & Sample J716 & $(0.0634)$ & & & & \\
\hline & Sample J719 & $(0.0825)$ & & & & \\
\hline & Sample J723 & $(0.144)$ & & & & \\
\hline & Sample J724 & $(0.0531)$ & & & & \\
\hline
\end{tabular}

Table A-3. Tank 241-C-110 Analytical Data: Strontium-90

\begin{tabular}{|c|c|c|c|c|c|c|}
\hline Analyte & $\begin{array}{l}\text { Laboratory } \\
\text { Sample } \\
\text { Identification }\end{array}$ & $\begin{array}{c}\text { Analytical } \\
\text { Data } \\
\text { Result }\end{array}$ & $\begin{array}{c}\text { Range } \\
\text { of } \\
\text { Values }\end{array}$ & $\begin{array}{l}\text { Weighted } \\
\text { Mean/ } \\
\text { Standard } \\
\text { Error }\end{array}$ & $\begin{array}{c}\text { Evaluated } \\
\text { Data } \\
\text { Result }\end{array}$ & $\begin{array}{l}\text { Projected } \\
\text { Inventory }\end{array}$ \\
\hline Radionuclide & & $\mu \mathrm{Ci} / \mathrm{mL}$ & $\mu \mathrm{Ci} / \mathrm{mL}$ & $\mu \mathrm{Ci} / \mathrm{mL}$ & $\mu \mathrm{Ci} / \mathrm{mL}$ & $\mathrm{Ci}$ \\
\hline $\begin{array}{r}\mathrm{BPC} .{ }^{90} \mathrm{Sr} \\
\text { (Liquid) }\end{array}$ & Sample $\mathbf{J} 800$ & $(0.0278)$ & N/A & $\cdots$ & 0.0278 & 0.737 \\
\hline Radionuclide & & $\mu \mathrm{Ci} / \mathrm{g}$ & $\mu \mathrm{Ci} / \mathrm{g}$ & $\mu \mathrm{Ci} / \mathrm{g}$ & $\mu \mathrm{Ci} / \mathrm{g}$ & $\mathrm{Ci}$ \\
\hline \multirow{5}{*}{$\begin{array}{r}\text { BPC. }{ }^{90} \mathrm{Sr} \\
\text { (Solid) }\end{array}$} & Sample J715 & $(7.17)$ & \multirow{5}{*}{$\begin{array}{l}3.61 \\
\text { to } \\
7.17\end{array}$} & \multirow[t]{5}{*}{5.00} & \multirow[t]{5}{*}{-} & \multirow[t]{5}{*}{5,140} \\
\hline & Sample $J 716$ & $(6.38)$ & & & & \\
\hline & Sample J719 & $(4.32)$ & & & & \\
\hline & Sample J723 & $(3.61)$ & & & & \\
\hline & Sample J724 & $(3.75)$ & & & & \\
\hline
\end{tabular}


Table A-3. Tank 241-C-110 Analytical Data: Selenium-79

\begin{tabular}{|c|c|c|c|c|c|c|}
\hline $\begin{array}{c}\text { Analyte } \\
:\end{array}$ & $\begin{array}{l}\text { Laboratory } \\
\text { Sample } \\
\text { Identification }\end{array}$ & $\begin{array}{c}\text { Analytical } \\
\text { Data } \\
\therefore \quad \text { Result } \\
\end{array}$ & $\begin{array}{cc}\text { Range } \\
\text { of } \\
\text { Values }\end{array}$ & $\begin{array}{c}\text { Weighted } \\
\text { Mean/ } \\
\text { Standard } \\
\text { Error }\end{array}$ & $\begin{array}{c}\text { Evaluated } \\
\text { Data } \\
\text { Result }\end{array}$ & $\begin{array}{c}\text { Projected } \\
\text { Inventory } \\
\ldots .\end{array}$ \\
\hline Radionuclide & & $\mu \mathrm{Ci} / \mathrm{mL}$ & $\mu \mathrm{Ci} / \mathrm{mL}$ & $\mu \mathrm{Ci} / \mathrm{mL}$ & $\mu \mathrm{Ci} / \mathrm{mL}$ & $\mathrm{Ci}$ \\
\hline $\begin{array}{r}\text { LSC. }^{79} \mathrm{Se} \\
\text { (Liquid) }\end{array}$ & Sample J800 & (6.17E-05) & $N / A$ & - & 6.17E-05 & 0.00163 \\
\hline Radionuclide & & $\mu \mathrm{Ci} / \mathrm{g}$ & $\mu \mathrm{Ci} / \mathrm{g}$ & $\mu \mathrm{Ci} / \mathrm{g}$ & $\mu \mathrm{Ci} / \mathrm{g}$ & $\mathrm{Ci}$ \\
\hline \multirow{5}{*}{$\begin{array}{r}\text { LSC. }^{79} \mathrm{Se} \\
\text { (Solid) }\end{array}$} & Sample J715 & (2.72E-04) & \multirow[t]{5}{*}{$N / A$} & \multirow[t]{5}{*}{0.00130} & \multirow[t]{5}{*}{$\cdots$} & \multirow[t]{5}{*}{1.34} \\
\hline & Sample $J 716$ & (2.88E-04) & & & & \\
\hline & Sample J719 & $(0.00368)$ & & & & \\
\hline & Sample J723 & $(<0.00259)$ & & & & \\
\hline & Sample J724 & $(<0.00250)$ & & & & \\
\hline
\end{tabular}

Table A-3. Tank 241-C-110 Analytical Data: Technicium-99

\begin{tabular}{|c|c|c|c|c|c|c|}
\hline Analyte & $\begin{array}{l}\text { Laboratory } \\
\text { Sample } \\
\text { Identification }\end{array}$ & $\begin{array}{c}\text { Analytical } \\
\text { Data } \\
\text { Result }\end{array}$ & $\begin{array}{c}\text { Range } \\
\text { of } \\
\text { Values }\end{array}$ & $\begin{array}{l}\text { Weighted } \\
\text { Mean/ } \\
\text { Standard } \\
\text { Error }\end{array}$ & $\begin{array}{c}\text { Evaluated } \\
\text { Data } \\
\text { Result }\end{array}$ & $\begin{array}{l}\text { Projected } \\
\text { Inventory }\end{array}$ \\
\hline $\begin{array}{l}\text { Radionuclide } \\
\text { (Liquid) }\end{array}$ & & $\mu \mathrm{Ci} / \mathrm{mL}$ & $\mu \mathrm{Ci} / \mathrm{mL}$ & $\mu \mathrm{Ci} / \mathrm{mL}$ & $\mu \mathrm{Ci} / \mathrm{mL}$ & $\mathrm{Ci}$ \\
\hline LSC. ${ }^{99} \mathrm{Tc}$ & Sample J800 & $(0.0162)$ & N/A & -- & 0.0162 & 0.429 \\
\hline $\begin{array}{l}\text { Radionuclide } \\
\text { (Solid) }\end{array}$ & & $\mu \mathrm{Ci} / \mathrm{g}$ & $\mu \mathrm{Ci} / \mathrm{g}$ & $\mu \mathrm{Ci} / \mathrm{g}$ & $\mu \mathrm{Ci} / \mathrm{g}$ & $\mathrm{Ci}$ \\
\hline \multirow[t]{5}{*}{ LSC. ${ }^{99} \mathrm{Tc}$} & Sample J715 & $(0.0463)$ & \multirow{5}{*}{$\begin{array}{c}0.0198 \\
\text { to } \\
0.0463\end{array}$} & \multirow[t]{5}{*}{0.0328} & \multirow[t]{5}{*}{$\cdots$} & \multirow[t]{5}{*}{33.7} \\
\hline & Sample J716 & $(0.0394)$ & & & & \\
\hline & Sample J719 & $(0.0198)$ & & & & \\
\hline & Sample J723 & $(0.0353)$ & & & & \\
\hline & Sample J724 & $(0.0362)$ & & & & \\
\hline
\end{tabular}


Table A-3. Tank 241-C-110 Analytical Data: Tritium

\begin{tabular}{|c|c|c|c|c|c|c|}
\hline $\begin{array}{lll} & \\
\because & \\
\because & \text { Analyte } \\
\because & \ddots & \vdots\end{array}$ & $\begin{array}{l}\text { Laboratory } \\
\text { Sample } \\
\text { Odentiticattiont }\end{array}$ & $\begin{array}{c}\text { Analytical } \\
\text { Data } \\
\text { Result } \\
\text { Res }\end{array}$ & $\begin{array}{c}\text { Range } \\
\text { of } \because \\
\text { Values }\end{array}$ & $\begin{array}{l}\text { Weighted } \\
\text { Neari/ } \\
\text { Standard } \\
\text { Error }\end{array}$ & $\begin{array}{l}\text { Evaluated } \\
\text { Data } \\
\text { Result } \\
\text { a }\end{array}$ & $\begin{array}{l}\text { Projected } \\
\text { Inventory }\end{array}$ \\
\hline Radionuclide & & $\mu \mathrm{Ci} / \mathrm{mL}$ & $\mu \mathrm{Ci} / \mathrm{mL}$ & $\mu \mathrm{Ci} / \mathrm{mL}$ & $\mu \mathrm{Ci} / \mathrm{mL}$ & $\mathrm{Ci}$ \\
\hline $\begin{array}{l}\text { LSC. }{ }^{3} \mathrm{H} \\
\text { (Liquid) }\end{array}$ & Sample J800 & $(7.18 E-04)$ & N/A & - & 7.18E-04 & 0.0190 \\
\hline Radionuclide & & $\mu \mathrm{Ci} / \mathrm{g}$ & $\mu \mathrm{Ci} / \mathrm{g}$ & $\mu \mathrm{Ci} / \mathrm{g}$ & $\mu \mathrm{Ci} / \mathrm{g}$ & $\mathrm{Ci}$ \\
\hline \multirow{5}{*}{$\begin{array}{l}\text { LSC. }^{3} \mathrm{H} \\
\text { (Solid) }\end{array}$} & Sample J694 & (8.20E-04) & \multirow{5}{*}{$\begin{array}{c}8.20 E-04 \\
\text { to } \\
0.00164 \\
.\end{array}$} & \multirow[t]{5}{*}{0.00118} & \multirow[t]{5}{*}{-} & \multirow[t]{5}{*}{1.21} \\
\hline & Sample J695 & (9.07E-04) & & & & \\
\hline & Sample J698 & $(0.00115)$ & & & & \\
\hline & Sample J702 & $(0.00145)$ & & & & \\
\hline & Sample J703 & $(0.00164)$ & & & & \\
\hline
\end{tabular}

Table A-3. Tank 241-C-110 Analytical Data: Uranium-238

\begin{tabular}{|c|c|c|c|c|c|c|}
\hline Analyte & $\begin{array}{l}\text { Laboratory } \\
\text { Sample } \\
\text { Identification }\end{array}$ & $\begin{array}{c}\text { Analytical } \\
\text { Data } \\
\text { Result }\end{array}$ & $\begin{array}{c}\text { Range } \\
\text { of } \\
\text { Values }\end{array}$ & $\begin{array}{l}\text { Weighted } \\
\text { Mean/ } \\
\text { Standard } \\
\text { Error }\end{array}$ & $\begin{array}{c}\text { Evaluated } \\
\text { Data } \\
\text { Result }\end{array}$ & $\begin{array}{l}\text { Projected } \\
\text { Inventory }\end{array}$ \\
\hline $\begin{array}{l}\text { Radionuclide } \\
\text { (Liquid) }\end{array}$ & & $\mu \mathrm{Ci} / \mathrm{mL}$ & $\mu \mathrm{Ci} / \mathrm{gmL}$ & $\mu \mathrm{Ci} / \mathrm{mL}$ & $\mu \mathrm{Ci} / \mathrm{mL}$ & $\mathrm{Ci}$ \\
\hline$L F .{ }^{238} \mathrm{U}$ & Sample J800 & 2.59E-06 & N/A & --- & 2.59E-06 & $6.86 \mathrm{E}-05$ \\
\hline $\begin{array}{l}\text { Radionuclide } \\
\text { (Solid) }\end{array}$ & & $\mu \mathrm{Ci} / \mathrm{g}$ & $\mu \mathrm{Ci} / \mathrm{g}$ & $\mu \mathrm{Cl} / \mathrm{g}$ & $\mu \mathrm{Ci} / \mathrm{g}$ & $\mathrm{Ci}$ \\
\hline \multirow[t]{6}{*}{ LF. ${ }^{238} \mathrm{U}$} & Sample J800 & 2.59E-06 & \multirow{6}{*}{$\begin{array}{c}3.37 E-04 \\
\text { to } \\
6.71 E-04\end{array}$} & \multirow[t]{6}{*}{ 4.95E-04 } & \multirow[t]{6}{*}{-} & \multirow[t]{6}{*}{0.508} \\
\hline & Sample J715 & 6.71E-04 & & & & \\
\hline & Sample $\mathbf{J 1 1 6}$ & 6.67E-04 & & & & \\
\hline & Sample J719 & 4.63E-04 & & & & \\
\hline & Sample J723 & 3.37E-04 & & & & \\
\hline & Sample J724 & 3.70E-04 & & & & \\
\hline
\end{tabular}


Table A-3. Tank 241-C-110 Analytical Data: Total Alpha

\begin{tabular}{|c|c|c|c|c|c|c|}
\hline Analyte & $\begin{array}{l}\text { Laboratory } \\
\text { Sample } \\
\text { Identification }\end{array}$ & $\begin{array}{c}\text { Analytical } \\
\text { Data } \\
\text { Result }\end{array}$ & $\begin{array}{c}\text { Range } \\
\text { of } \\
\text { Values }\end{array}$ & $\begin{array}{l}\text { Weighted } \\
\text { Mean/ } \\
\text { Standard } \\
\text { Error }\end{array}$ & $\begin{array}{c}\text { Evaluated } \\
\text { Data } \\
\text { Result }\end{array}$ & $\begin{array}{l}\text { Projected } \\
\text { Inventory }\end{array}$ \\
\hline Radionuclide & & $\mu \mathrm{Ci} / \mathrm{mL}$ & $\mu \mathrm{Ci} / \mathrm{mL}$ & $\mu \mathrm{Ci} / \mathrm{mL}$ & $\mu \mathrm{Ci} / \mathrm{mL}$ & $\mathrm{Ci}$ \\
\hline \multirow{5}{*}{$\begin{array}{l}\text { APC.Total } \\
\text { Alpha (Liquid) }\end{array}$} & Sample J775 & 0.00436 & \multirow{5}{*}{$\begin{array}{c}<3.69 E-07 \\
\text { to } \\
0.00436\end{array}$} & \multirow[t]{5}{*}{$\cdots$} & \multirow[t]{5}{*}{ 7.02E-04 } & \multirow[t]{5}{*}{0.186} \\
\hline & Sample J761 & $(<3.69 E-07)$ & & & & \\
\hline & Sample J800 & 0.00207 & & & & \\
\hline & Sample J783 & $<7.34 \mathrm{E}-04$ & & & & \\
\hline & Sample $J 778$ & $<0.02 E-04$ & & & & \\
\hline Radionuclide & & $\mu \mathrm{Ci} / \mathrm{g}$ & $\mu \mathrm{Ci} / \mathrm{g}$ & $\mu \mathrm{Ci} / \mathrm{g}$ & $\mu \mathrm{Ci} / \mathrm{g}$ & $\mathrm{Ci}$ \\
\hline \multirow{5}{*}{$\begin{array}{r}\text { APC.Total } \\
\text { Alpha } \\
\text { (Solid) }\end{array}$} & Sample J715 & 0.136 & \multirow{5}{*}{$\begin{array}{c}0.00436 \\
\text { to } \\
0.140\end{array}$} & \multirow{5}{*}{$\begin{array}{c}0.125 \\
0.00744\end{array}$} & \multirow[t]{5}{*}{--} & \multirow[t]{9}{*}{128} \\
\hline & Sample $\mathrm{J716}$ & 0.140 & & & & \\
\hline & Sample J719 & 0.126 & & & & \\
\hline & Sample J723 & 0.113 & & & & \\
\hline & Sample J724 & 0.113 & & & & \\
\hline \multirow{4}{*}{$\begin{array}{l}\text { Total Alpha } \\
\text { Homogenized } \\
\text { Sample }\end{array}$} & Sample J647 & 0.132 & \multirow{4}{*}{$\begin{array}{c}0.111 \\
\text { to } \\
0.133\end{array}$} & \multirow[t]{4}{*}{---} & \multirow[t]{4}{*}{$\cdots$} & \\
\hline & Sample J649 & 0.133 & & & & \\
\hline & Sample J658 & 0.120 & & & & \\
\hline & Sample J656 & 0.111 & & & & \\
\hline
\end{tabular}




\section{WHC-SD-WM-ER-367 REV O}

Table A-3. Tank 241-C-110 Analytical Data: Total Beta

\begin{tabular}{|c|c|c|c|c|c|c|}
\hline Analyte & $\begin{array}{l}\text { Laboratory } \\
\text { Sample } \\
\text { Identification }\end{array}$ & $\begin{array}{c}\text { Analytical } \\
\text { Data } \\
\text { Result }\end{array}$ & $\begin{array}{c}\text { Range } \\
\text { of } \\
\text { Values }\end{array}$ & $\begin{array}{l}\text { Weighted } \\
\text { Mean/ } \\
\text { Standard } \\
\text { Error }\end{array}$ & $\begin{array}{c}\text { Evaluated } \\
\text { Data } \\
\text { Result }\end{array}$ & $\begin{array}{l}\text { Projected } \\
\text { Inventory }\end{array}$ \\
\hline Radionuclide & & $\mu \mathrm{Ci} / \mathrm{mL}$ & $\mu \mathrm{Ci} / \mathrm{mL}$ & $\mu \mathrm{Ci} / \mathrm{mL}$ & $\mu \mathrm{Ci} / \mathrm{mL}$ & $\mathrm{Ci}$ \\
\hline \multirow{5}{*}{$\begin{array}{r}\text { BPC.Total } \\
\text { Beta } \\
\text { (Liquid) }\end{array}$} & Sample J761 & 3.93E-04 & \multirow{5}{*}{$\begin{array}{c}3.93 E-04 \\
\text { to } \\
8.15\end{array}$} & \multirow[t]{5}{*}{---} & \multirow[t]{5}{*}{3.76} & \multirow[t]{5}{*}{99.6} \\
\hline & Sample J800 & 5.68 & & & & \\
\hline & Sample $J 783$ & 1.20 & & & & \\
\hline & Sample J775 & 27.6 & & & & \\
\hline & Sample J778 & 8.15 & & & & \\
\hline Radionuclide & & $\mu \mathrm{Ci} / \mathrm{g}$ & $\mu \mathrm{Ci} / \mathrm{g}$ & $\mu \mathrm{Ci} / \mathrm{g}$ & $\mu \mathrm{Ci} / \mathrm{g}$ & $\mathrm{Ci}$ \\
\hline \multirow{5}{*}{$\begin{array}{r}\text { BPC.Total } \\
\text { Beta } \\
\text { (Solid) }\end{array}$} & Sample J715 & 41.6 & \multirow{5}{*}{$\begin{array}{l}27.6 \\
\text { to } \\
45.8\end{array}$} & \multirow[t]{5}{*}{42.4} & \multirow[t]{5}{*}{--} & \multirow[t]{5}{*}{43,500} \\
\hline & Sample $J 716$ & 40.1 & & & & \\
\hline & Sample J719 & 40.9 & & & & \\
\hline & Sample J723 & $(45.7)$ & & & & \\
\hline & Sample J724 & $(45.8)$ & & & & \\
\hline
\end{tabular}


WHC-SD-WM-ER-367 REV O

Table A-4. Tank 241-C-110 Analytical Data: Percent Water

\begin{tabular}{|c|c|c|c|c|c|c|}
\hline Analyte & $\begin{array}{l}\text { Laboratory } \\
\text { Sample } \\
\text { Identification }\end{array}$ & $\begin{array}{c}\text { Analytical } \\
\text { Data } \\
\text { Result }\end{array}$ & $\begin{array}{c}\text { Range } \\
\text { of } \\
\text { Values }\end{array}$ & $\begin{array}{l}\text { Weighted } \\
\text { Mean/ } \\
\text { Standard } \\
\text { Error }\end{array}$ & $\begin{array}{c}\text { Evaluated } \\
\text { Data } \\
\text { Result }\end{array}$ & $\begin{array}{l}\text { Projected } \\
\text { Inventory }\end{array}$ \\
\hline $\begin{array}{l}\text { Physical } \\
\text { Propeties }\end{array}$ & & $\%$ & $\%$ & $\%$ & $\%$ & \\
\hline \multirow{3}{*}{$\begin{array}{l}\text { \% Water } \\
\text { Core Sample }\end{array}$} & Sample $\mathbf{J 7 8 6}$ & 57.88 & \multirow{3}{*}{$\begin{array}{c}57.88 \\
\text { to } \\
63.50\end{array}$} & \multirow[t]{3}{*}{59.8} & \multirow[t]{3}{*}{$\cdots$} & \multirow[t]{10}{*}{$\cdots$} \\
\hline & Sample $J 789$ & 61.71 & & & & \\
\hline & Sample $J 791$ & 61.8 & & & & \\
\hline \multirow{7}{*}{$\begin{array}{l}\% \text { Water } \\
\text { Segment } \\
\text { Sample }\end{array}$} & Sample J583 & 60.4 & \multirow{7}{*}{$\cdots$} & \multirow[t]{7}{*}{--} & \multirow[t]{7}{*}{--} & \\
\hline & Sample J587 & 58.6 & & & & \\
\hline & Sample J614 & 61.15 & & & & \\
\hline & Sample J620 & 63.50 & & & & \\
\hline & Sample J625 & 59.25 & & & & \\
\hline & Sample J627 & 60.6 & & & & \\
\hline & Sample J629 & 60.4 & & & & \\
\hline
\end{tabular}

Table A-4. Tank 241-C-110 Analytical Data: pH

\begin{tabular}{|c|c|c|c|c|c|c|}
\hline Analyte & $\begin{array}{l}\text { Laboratory } \\
\text { Sample } \\
\text { Identification }\end{array}$ & $\begin{array}{c}\text { Analytical } \\
\text { Data } \\
\text { Result }\end{array}$ & $\begin{array}{c}\text { Range } \\
\text { of } \\
\text { Values }\end{array}$ & $\begin{array}{l}\text { Weighted } \\
\text { Mean/ } \\
\text { Standard } \\
\text { Error }\end{array}$ & $\begin{array}{c}\text { Evaluated } \\
\text { Data } \\
\text { Result }\end{array}$ & $\begin{array}{l}\text { Projected } \\
\text { Inventory }\end{array}$ \\
\hline \multicolumn{7}{|l|}{$\begin{array}{l}\text { Physical } \\
\text { Propeties }\end{array}$} \\
\hline $\mathrm{pH}$ & Sample J800 & 10.43 & 10.43 & --- & $\cdots$ & \multirow[t]{6}{*}{--} \\
\hline & Sample J694 & 11.04 & \multirow{5}{*}{$\begin{array}{c}10.78 \\
\text { to } \\
11.31\end{array}$} & \multirow[t]{2}{*}{11.0} & \multirow[t]{5}{*}{--} & \\
\hline & Sample J695 & 11.31 & & & & \\
\hline & Sample J698 & 10.78 & & \multirow[t]{3}{*}{0.104} & & \\
\hline & Sample $\mathrm{J} 702$ & 10.88 & & & & \\
\hline & Sample $J 703$ & 11.12 & & & & \\
\hline
\end{tabular}


Table A-4. Tank 241-C-110 Analytical Data: Total Inorganic Carbon

\begin{tabular}{|c|c|c|c|c|c|c|}
\hline \begin{tabular}{cc} 
& \\
Analyte & $\vdots$ \\
\hdashline & $\vdots$
\end{tabular} & $\begin{array}{c}\text { Laboratory } \\
\text { Sample } \\
\text { Sdentification }\end{array}$ & $\begin{array}{c}\text { Analytical } \\
\text { Data } \\
\therefore \text { Result }\end{array}$ & $\begin{array}{c}\text { Range } \\
\text { of } \\
\text { Values } \\
\because \text {. }\end{array}$ & $\begin{array}{l}\text { Weighted } \\
\text { Mean/ } \\
\text { Standard } \\
\text { Error }\end{array}$ & $\begin{array}{c}\text { Evaluated } \\
\text { Data } \\
\text { Result }\end{array}$ & $\begin{array}{l}\text { Projected } \\
\text { Inventory }\end{array}$ \\
\hline $\begin{array}{l}\text { Physical } \\
\text { Propeties }\end{array}$ & & $\mu \mathrm{g} / \mathrm{mL}$ & $\mu \mathrm{g} / \mathrm{mL}$ & $\mu \mathrm{g} / \mathrm{mL}$ & $\mu g / m L$ & kg \\
\hline TIC (Liquid) & Sample J800 & $(<543)$ & N/A & $\cdots$ & $<543$ & \multirow[t]{6}{*}{1,440} \\
\hline \multirow{5}{*}{ Core Sample } & Sample J694 & $(2,990)$ & \multirow{5}{*}{$\begin{array}{l}1,590 \\
\text { to } \\
2,990\end{array}$} & \multirow[t]{5}{*}{2,030} & \multirow[t]{5}{*}{-} & \\
\hline & Sample J695 & $(1,590)$ & & & & \\
\hline & Sample J698 & 1,660 & & & & \\
\hline & Sample J702 & 1,710 & & & & \\
\hline & Sample J703 & $(2,540)$ & & & & \\
\hline
\end{tabular}

Table A-4. Tank 241-C-110 Analytical Data: Total Organic Carbon

\begin{tabular}{|c|c|c|c|c|c|c|}
\hline Analyte & $\begin{array}{l}\text { Laboratory } \\
\text { Sample } \\
\text { Identification }\end{array}$ & $\begin{array}{c}\text { Analytical } \\
\text { Data } \\
\text { Result }\end{array}$ & $\begin{array}{c}\text { Range } \\
\text { of } \\
\text { Values }\end{array}$ & $\begin{array}{l}\text { Weighted } \\
\text { Mean/ } \\
\text { Standard } \\
\text { Error }\end{array}$ & $\begin{array}{c}\text { Evaluated } \\
\text { Data } \\
\text { Result }\end{array}$ & $\begin{array}{l}\text { Projected } \\
\text { Inventory }\end{array}$ \\
\hline $\begin{array}{l}\text { Physical } \\
\text { Propeties }\end{array}$ & & $\mu \mathrm{g} / \mathrm{mL}$ & $\mu \mathrm{g} / \mathrm{mL}$ & $\mu \mathrm{g} / \mathrm{mL}$ & $\mu \mathrm{g} / \mathrm{mL}$ & $\mathrm{kg}$ \\
\hline \multirow[t]{4}{*}{ TOC (Liquid) } & Sample J800 & $(580)$ & \multirow{4}{*}{$\begin{array}{l}410 \\
\text { to } \\
580\end{array}$} & & \multirow[t]{4}{*}{592} & \multirow[t]{4}{*}{15.7} \\
\hline & Sample $J 783$ & 410 & & & & \\
\hline & Sample J778 & 603 & & & & \\
\hline & Sample $J 775$ & 775 & & & & \\
\hline $\begin{array}{l}\text { Physical } \\
\text { Properties }\end{array}$ & & $\mu g / g$ & $\mu \mathrm{g} / \mathrm{g}$ & & $\mu g / g$ & $\mathrm{Kg}$ \\
\hline \multirow[t]{5}{*}{ TOC (Solid) } & Sample J694 & $(<1,050)$ & \multirow{5}{*}{$\begin{array}{c}<500 \\
\text { to } \\
1,090\end{array}$} & \multirow[t]{5}{*}{802} & \multirow[t]{5}{*}{--} & \multirow[t]{5}{*}{823} \\
\hline & Sample J695 & 1,090 & & & & \\
\hline & Sample J698 & $<500$ & & & & \\
\hline & Sample J702 & 514 & & & & \\
\hline & Sample $\mathrm{J} 703$ & $<500$ & & & & \\
\hline
\end{tabular}


WHC-SD-WM-ER-367 REV 0

Table A-4. Tank 241-C-110 Analytical Data: Thermogravimetric Analysis

\begin{tabular}{|c|c|c|c|c|c|c|}
\hline Analyte & $\begin{array}{l}\text { Laboratory } \\
\text { Sample } \\
\text { Identification }\end{array}$ & $\begin{array}{c}\text { Analytical } \\
\text { Data } \\
\text { Result }\end{array}$ & $\begin{array}{c}\text { Range } \\
\text { of } \\
\text { Values }\end{array}$ & $\begin{array}{l}\text { Weighted } \\
\text { Mean/ } \\
\text { Standard } \\
\text { Error }\end{array}$ & $\begin{array}{c}\text { Evaluated } \\
\text { Data } \\
\text { Result }\end{array}$ & $\begin{array}{l}\text { Projected } \\
\text { Inventory }\end{array}$ \\
\hline $\begin{array}{l}\text { Physical } \\
\text { Propeties }\end{array}$ & & $\%$ & $\%$ & $\%$ & $\%$ & \\
\hline \multirow[t]{5}{*}{ TGA } & Sample J634 & 58.7 & \multirow{5}{*}{$\begin{array}{c}52.0 \\
\text { to } \\
62.0\end{array}$} & \multirow[t]{2}{*}{57.5} & \multirow[t]{5}{*}{--} & \\
\hline & Sample J635 & 54.1 & & & & \\
\hline & Sample J636 & 62.0 & & \multirow[t]{3}{*}{2.07} & & \\
\hline & Sample J639 & 56.3 & & & & \\
\hline & Sample J640 & 52.0 & & & & \\
\hline $\begin{array}{l}\text { Physical } \\
\text { Properties }\end{array}$ & & $\%$ & $\%$ & $\%$ & $\%$ & \\
\hline \multirow[t]{5}{*}{ TGA } & Sample J591 & 50.6 & \multirow{5}{*}{$\begin{array}{l}50.1 \\
\text { to } \\
54.2\end{array}$} & \multirow[t]{5}{*}{--- } & \multirow[t]{5}{*}{--} & \\
\hline & Sample J593 & 54.2 & & & & \\
\hline & Sample J596 & 53.8 & & & & \\
\hline & Sample J598 & 50.1 & & & & \\
\hline & Sample J599 & 53.2 & & & & \\
\hline
\end{tabular}

Table A-4. Tank 241-C-110 Analytical Data: Specific Gravity

\begin{tabular}{|c|c|c|c|c|c|c|}
\hline Analyte & $\begin{array}{l}\text { Laboratory } \\
\text { Sample } \\
\text { Identification }\end{array}$ & $\begin{array}{c}\text { Analytical } \\
\text { Data } \\
\text { Result }\end{array}$ & $\begin{array}{c}\text { Range } \\
\text { of } \\
\text { Values }\end{array}$ & $\begin{array}{l}\text { Weighted } \\
\text { Mean/ } \\
\text { Standard } \\
\text { Error }\end{array}$ & $\begin{array}{c}\text { Evaluated } \\
\text { Data } \\
\text { Result }\end{array}$ & $\begin{array}{l}\text { Projected } \\
\text { Inventory }\end{array}$ \\
\hline $\begin{array}{l}\text { Physical } \\
\text { Propeties }\end{array}$ & & & & & & $\mathrm{kg}$ \\
\hline \multirow[t]{3}{*}{ SpG } & Sample J783 & 1.00 & \multirow{3}{*}{$\begin{array}{l}1.00 \\
\text { to } \\
1.18\end{array}$} & \multirow[t]{3}{*}{---} & \multirow[t]{3}{*}{1.09} & \multirow[t]{3}{*}{---} \\
\hline & Sample J778 & 1.10 & & & & \\
\hline & Sample J635 & 1.18 & & & & \\
\hline
\end{tabular}


Table A-5. Tank 241-C-110 Analytical Data: Volatile Organics

\begin{tabular}{|c|c|c|c|}
\hline Analyte & $\begin{array}{c}\text { Result } \\
\text { ug/L }\end{array}$ & Analyte & $\begin{array}{c}\text { Result } \\
\text { ug/L }\end{array}$ \\
\hline Chloromethane & ND & 1,2-Dichloropropane & ND \\
\hline Bromomethane & ND & Tetrachloroethene & ND \\
\hline Vinyl Chloride & ND & Trichloroethene & ND \\
\hline Chloroethane & ND & Dibromochloromethane & ND \\
\hline Methylene Chloride & ND & 1,1,2-Trichloroethane & ND \\
\hline Acetone & ND & Benzene & ND \\
\hline Carbon Disulfide & ND & 2-Hexanone & ND \\
\hline 1,1-Dichloroethene & ND & Bromoform & ND \\
\hline 1,1-Dichloroethane & ND & 4-Methyl-2-Pentanone & ND \\
\hline trans-1,2-Dichloroethene & ND & trans-1,3-Dichloropropene & ND \\
\hline cis-1,2-Dichloroethene & ND & cis-1,3-Dichloropropene & ND \\
\hline Chloroform & ND & $1,1,2,2$-Tetrachloroethane & ND \\
\hline 1,2-Dichloroethane & ND & Toluene & ND \\
\hline 2-Butanone & ND & Chlorobenzene & ND \\
\hline 1,1,1-Trichloroethane & ND & Ethylbenzene & ND \\
\hline Carbon Tetrachloride & ND & Styrene & ND \\
\hline Vinyl Acetate & ND & Xylene (total) & ND \\
\hline Bromodichloromethane & ND & & \\
\hline
\end{tabular}


Table A-5. Tank 241-C-110 Analytical Data: Decane

\begin{tabular}{|c|c|c|c|c|c|c|}
\hline Analyte $\ldots$ & $\begin{array}{c}\text { Laboratory } \\
\text { Sample } \\
\text { ldentitification }\end{array}$ & $\begin{array}{lc} & \text { Analytical : } \\
\therefore \quad \text { Data } & \text { Result } \\
\therefore \quad & \cdots \\
\end{array}$ & $\begin{array}{c}\text { Range } \\
\text { of } \\
\text { Values }\end{array}$ & $\begin{array}{l}\text { Weighted } \\
\text { Mean/ } \\
\text { Stäriard } \\
\text { Error }\end{array}$ & $\begin{array}{l}\text { Evaluated } \\
\text { Data } \\
\text { Result } \\
\quad \therefore\end{array}$ & $\begin{array}{l}\text { Projected } \\
\text { inventory } \\
\therefore \quad\end{array}$ \\
\hline VOA & & $\mu g / \mathrm{kg}$ & $\mu \mathrm{g} / \mathrm{kg}$ & $\mu \mathrm{g} / \mathrm{kg}$ & $\mu \mathrm{g} / \mathbf{k g}$ & $\mathrm{kg}$ \\
\hline \multirow[t]{5}{*}{ GC/MS.Decane } & Sample J742 & $(4,850)$ & \multirow{5}{*}{$\begin{array}{c}2,050 \\
\text { to } \\
5,600\end{array}$} & \multirow[t]{5}{*}{3,470} & \multirow[t]{5}{*}{$\cdots$} & \multirow[t]{5}{*}{3.57} \\
\hline & Sample J745 & $(3,600)$ & & & & \\
\hline & Sample J747 & $(2,350)$ & & & & \\
\hline & Sample J748 & $(5,600)$ & & & & \\
\hline & Sample J749 & $(2,050)$ & & & & \\
\hline
\end{tabular}

Table A-5. Tank 241-C-110 Analytical Data: Undecane

\begin{tabular}{|c|c|c|c|c|c|c|}
\hline Analyte & $\begin{array}{l}\text { Laboratory } \\
\text { Sample } \\
\text { Identification }\end{array}$ & $\begin{array}{c}\text { Analytical } \\
\text { Data } \\
\text { Result }\end{array}$ & $\begin{array}{c}\text { Range } \\
\text { of } \\
\text { Values }\end{array}$ & $\begin{array}{l}\text { Weighted } \\
\text { Mean/ } \\
\text { Standard } \\
\text { Error }\end{array}$ & $\begin{array}{c}\text { Evaluated } \\
\text { Data } \\
\text { Result }\end{array}$ & $\begin{array}{l}\text { Projected } \\
\text { Inventory }\end{array}$ \\
\hline VOA & & $\mu \mathrm{g} / \mathrm{kg}$ & $\mu \mathrm{g} / \mathrm{kg}$ & $\mu \mathrm{g} / \mathrm{kg}$ & $\mu \mathrm{g} / \mathrm{kg}$ & $\mathrm{kg}$ \\
\hline \multirow{5}{*}{$\begin{array}{r}\text { GC/MS. } \\
\text { Undecane }\end{array}$} & Sample J742 & $(4,900)$ & \multirow{5}{*}{$\begin{array}{l}2,650 \\
\text { to } \\
5,050\end{array}$} & \multirow[t]{5}{*}{3,540} & \multirow[t]{5}{*}{--} & \multirow[t]{5}{*}{3.65} \\
\hline & Sample J745 & $(3,150)$ & & & & \\
\hline & Sample J747 & $(2,650)$ & & & & \\
\hline & Sample J748 & $(5,050)$ & & & & \\
\hline & Sample J749 & $(2,850)$ & & & & \\
\hline
\end{tabular}


Table A-5. Tank 241-C-110 Analytical Data: Dodecane

\begin{tabular}{|c|c|c|c|c|c|c|}
\hline 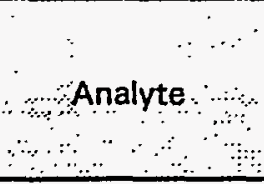 & $\begin{array}{l}\text { Laboratory } \\
\text { Sample. } \\
\text { Tdentification }\end{array}$ & $\begin{array}{c}\text { Analytical } \\
\text { Data } \\
\text { Result } \\
\text { Result } \\
\end{array}$ & $\begin{array}{r}\text { Range } \\
\text { of } \\
\text { Values }\end{array}$ & $\begin{array}{l}\text { Weighted } \\
\text { Mëanl } \\
\text { Stañdard } \\
\text { Error }\end{array}$ & $\begin{array}{l}\text { Evaluated } \\
\text { Data } \\
\text { Result }\end{array}$ & $\begin{array}{l}\text { Projected } \\
\text { Inveritory } \\
\cdots\end{array}$ \\
\hline VOA & & $\mu \mathrm{g} / \mathrm{kg}$ & $\mu \mathrm{g} / \mathrm{kg}$ & $\mu \mathrm{g} / \mathrm{kg}$ & $\mu \mathrm{g} / \mathrm{kg}$ & $\mathrm{kg}$ \\
\hline \multirow{5}{*}{$\begin{array}{r}\text { GC/MS. } \\
\text { Dodecane }\end{array}$} & Sample J742 & $(44,500)$ & \multirow{5}{*}{$\begin{array}{l}26,500 \\
\text { to } \\
44,500\end{array}$} & \multirow[t]{5}{*}{33,800} & \multirow[t]{5}{*}{-} & \multirow[t]{5}{*}{3.48} \\
\hline & Sample J745 & $(33,000)$ & & & & \\
\hline & Sample J747 & $(26,500)$ & & & & \\
\hline & Sample J748 & $(34,500)$ & & & & \\
\hline & Sample $\mathbf{J 7 4 9}$ & $(37,500)$ & & & & \\
\hline
\end{tabular}

Table A-5. Tank 241-C-110 Analytical Data: Tridecane

\begin{tabular}{|c|c|c|c|c|c|c|}
\hline Analyte & $\begin{array}{l}\text { Laboratory } \\
\text { Sample } \\
\text { Identification }\end{array}$ & $\begin{array}{c}\text { Analytical } \\
\text { Data } \\
\text { Result }\end{array}$ & $\begin{array}{c}\text { Range } \\
\text { of } \\
\text { Values }\end{array}$ & $\begin{array}{c}\text { Weighted } \\
\text { Mean/ } \\
\text { Standard } \\
\text { Error }\end{array}$ & $\begin{array}{c}\text { Evaluated } \\
\text { Data } \\
\text { Result }\end{array}$ & $\begin{array}{l}\text { Projected } \\
\text { Inventory }\end{array}$ \\
\hline VOA & & $\mu \mathrm{g} / \mathrm{kg}$ & $\mu \mathrm{g} / \mathrm{kg}$ & $\mu \mathrm{g} / \mathrm{kg}$ & $\mu \mathrm{g} / \mathrm{kg}$ & kg \\
\hline \multirow{5}{*}{$\begin{array}{l}\text { GC/MS. } \\
\text { Tridecane }\end{array}$} & Sample J742 & $(19,000)$ & \multirow{5}{*}{$\begin{array}{c}10,400 \\
\text { to } \\
19,000\end{array}$} & \multirow[t]{5}{*}{15,300} & \multirow[t]{5}{*}{$\cdots$} & \multirow[t]{5}{*}{15.8} \\
\hline & Sample J745 & $(15,500)$ & & & & \\
\hline & Sample $\mathrm{J747}$ & $(10,400)$ & & & & \\
\hline & Sample J748 & $(17,500)$ & & & & \\
\hline & Sample $J 749$ & $(19,000)$ & & & & \\
\hline
\end{tabular}


WHC-SD-WM-ER-367 REV O

Table A-5. Tank 241-C-110 Analytical Data: Tetradecane

\begin{tabular}{|c|c|c|c|c|c|c|}
\hline $\begin{array}{c}\text { Analyte } \ldots \\
\ldots\end{array}$ & $\begin{array}{c}\text { Laboratory } \\
\text { Sample } \\
\text { Idêntitication }\end{array}$ & $\begin{array}{c}\text { Analytical } \\
\quad \text { Data } \\
\because \text { Result } \\
\end{array}$ & $\begin{array}{c}\text { Range } \\
\text { of } \\
\text { Values } \\
\therefore\end{array}$ & $\begin{array}{l}\text { Weighted } \\
\text { Mean/ } \\
\text { Standard } \\
\text { Error }\end{array}$ & $\begin{array}{c}\text { Evaluated } \\
\text { Data } \\
\text { Result }\end{array}$ & $\begin{array}{l}\text { Projected } \\
\text { Inventory }\end{array}$ \\
\hline VOA & & $\mu \mathrm{g} / \mathrm{kg}$ & $\mu \mathrm{g} / \mathrm{kg}$ & $\mu \mathrm{g} / \mathrm{kg}$ & $\mu \mathrm{g} / \mathrm{kg}$ & $\mathrm{kg}$ \\
\hline \multirow{5}{*}{$\begin{array}{l}\text { GC/MS. } \\
\text { Tetradecane }\end{array}$} & Sample J742 & $(3,750)$ & \multirow{5}{*}{$\begin{array}{l}2,050 \\
\text { to } \\
4,650\end{array}$} & \multirow[t]{2}{*}{3,080} & \multirow[t]{5}{*}{--} & \multirow[t]{5}{*}{3.17} \\
\hline & Sample J745 & $(2,500)$ & & & & \\
\hline & Sample J747 & $(2,050)$ & & \multirow[t]{3}{*}{1,010} & & \\
\hline & Sample J748 & $(4,650)$ & & & & \\
\hline & Sample J749 & $(3,500)$ & & & & \\
\hline
\end{tabular}


Table A-6. Tank 241-C-110 Analytical Data: Semivolatile Organic

\begin{tabular}{|c|c|c|c|}
\hline Analyte & $\begin{array}{c}\text { Result } \\
\text { ug/L }\end{array}$ & Analyte & $\begin{array}{c}\text { Result } \\
\text { ug/L }\end{array}$ \\
\hline Phenol & ND & 3-Nitroaniline & ND \\
\hline bis (2-Chloroethyl)ether & ND & Acenaphthene & ND \\
\hline 2-Chlorophenol & ND & 2,4-Dinitrophenol & ND \\
\hline 1,3-Dichlorobenzene & ND & 4-Nitrophenol & ND \\
\hline 1,4-Dichlorobenzene & ND & Dibenzofuran & ND \\
\hline Benzyl alcohol & ND & 2,4-Dinitrotoluene & ND \\
\hline 1,2-Dichlorobenzene & ND & Diethylphthalate & ND \\
\hline 2-Methylphenol & ND & Fluorene & ND \\
\hline bis(2-Chloroisopropyl)ether & ND & 4-Chlorophenyl-phenylether & ND \\
\hline 4-Methylphenol & ND & 4-Nitroaniline & ND \\
\hline N-Nitroso-di-n-propylamine & ND & 4,6-Dinitro-2-methylphenol & ND \\
\hline Hexachloroethane & ND & 4-Bromophenyl-phenylether & ND \\
\hline Nitrobenzene & ND & N-Nitrosodiphenylamine (1) & ND \\
\hline Isophorone & ND & Hexachlorobenzene & ND \\
\hline 2-Nitrophenol & ND & Dibenz(a,h)anthracene & ND \\
\hline 2,4-Dimethylphenol & ND & Benzolg,h,ilperylene & ND \\
\hline Benzoic acid & ND & Pentachlorophenol & ND \\
\hline bis(2-Chloroethoxy)methane & ND & Phenanthrene & ND \\
\hline 2,4-Dichlorophenol & ND & Anthracene & ND \\
\hline 1,2,4-Trichlorobenzene & ND & Di-n-butylphthalate & ND \\
\hline Naphthalene & ND & Fluoranthene & ND \\
\hline 4-Chloroaniline & ND & Pyrene & ND \\
\hline Hexachlorobutadiene & ND & Butylbenzylphthalate & ND \\
\hline 4-Chloro-3-methylphenol & ND & 3,3'-Dichlorobenzidine & ND \\
\hline 2-Methylnaphthalene & ND & Benzola)anthracene & ND \\
\hline Hexachlorocyclopentadiene & ND & Chrysene & ND \\
\hline 2,4,6-Trichlorophenol & ND & bis-(2-Ethylexyl)phthalate & ND \\
\hline 2,4,5-Trichlorophenol & ND & Di-n-octylphthalate & ND \\
\hline 2-Chloronaphthalene & ND & Benzo(b)fluoranthene & ND \\
\hline 2-Nitroaniline & ND & Benzo(k)fluoranthene & ND \\
\hline Dimethylphthalate & ND & Benzo(a)pyrene & ND \\
\hline Acenaphthalate & ND & Indeno(1,2,3-cd)pyrene & ND \\
\hline 2,6-Dinitrotoluene & ND & & \\
\hline
\end{tabular}


Table A-6. Tank 241-C-110 Analytical Data: Decane

\begin{tabular}{|c|c|c|c|c|c|c|}
\hline Analyte & $\begin{array}{l}\text { Laboratory } \\
\text { Sample } \\
\text { Identification }\end{array}$ & $\begin{array}{c}\text { Analytical } \\
\text { Data } \\
\text { Result }\end{array}$ & $\begin{array}{c}\text { Range } \\
\text { of } \\
\text { Values }\end{array}$ & $\begin{array}{l}\text { Weighted } \\
\text { Mean/ } \\
\text { Standard } \\
\text { Error }\end{array}$ & $\begin{array}{c}\text { Evaluated } \\
\text { Data } \\
\text { Result }\end{array}$ & $\begin{array}{l}\text { Projected } \\
\text { Inventory }\end{array}$ \\
\hline SVOA & & $\mu \mathrm{g} / \mathrm{kg}$ & $\mu \mathrm{g} / \mathrm{kg}$ & $\mu \mathrm{g} / \mathrm{kg}$ & $\mu \mathrm{g} / \mathrm{kg}$ & $\mathrm{kg}$ \\
\hline \multirow[t]{2}{*}{ GC/MS.Decane } & Sample 92-08309 & $(8,700)$ & \multirow{2}{*}{$\begin{array}{c}8,600 \\
\text { to } \\
8,700\end{array}$} & 8,650 & \multirow[t]{2}{*}{--} & \multirow[t]{2}{*}{8.91} \\
\hline & Sample 92-08311 & $(8,600)$ & & 70.7 & & \\
\hline
\end{tabular}

Table A-6. Tank 241-C-110 Analytical Data: Undecane

\begin{tabular}{|c|c|c|c|c|c|c|}
\hline Analyte & $\begin{array}{l}\text { Laboratory } \\
\text { Sample } \\
\text { Identification }\end{array}$ & $\begin{array}{c}\text { Analytical } \\
\text { Data } \\
\text { Result }\end{array}$ & $\begin{array}{c}\text { Range } \\
\text { of } \\
\text { Values }\end{array}$ & $\begin{array}{l}\text { Weighted } \\
\text { Mean/ } \\
\text { Standard } \\
\text { Error }\end{array}$ & $\begin{array}{c}\text { Evaluated } \\
\text { Data } \\
\text { Result }\end{array}$ & $\begin{array}{l}\text { Projected } \\
\text { Inventory }\end{array}$ \\
\hline SVOA & & $\mu \mathrm{g} / \mathrm{kg}$ & $\mu \mathrm{g} / \mathrm{kg}$ & $\mu \mathrm{g} / \mathrm{kg}$ & $\mu \mathrm{g} / \mathrm{kg}$ & $\mathrm{kg}$ \\
\hline \multirow{3}{*}{$\begin{array}{r}\text { GC/MS. } \\
\text { Undecane }\end{array}$} & Sample 92-08307 & $(19,000)$ & \multirow{3}{*}{$\begin{array}{c}15,000 \\
\text { to } \\
19,000\end{array}$} & \multirow[t]{3}{*}{17,800} & \multirow[t]{3}{*}{--} & \multirow[t]{3}{*}{18.3} \\
\hline & Sample 92-08309 & $(15,000)$ & & & & \\
\hline & Sample 92-08311 & $(18,000)$ & & & & \\
\hline
\end{tabular}

Table A-6. Tank 241-C-110 Analytical Data: Dodecane

\begin{tabular}{|c|c|c|c|c|c|c|}
\hline Analyte & $\begin{array}{l}\text { Laboratory } \\
\text { Sample } \\
\text { Identification }\end{array}$ & $\begin{array}{c}\text { Analytical } \\
\text { Data } \\
\text { Result }\end{array}$ & $\begin{array}{c}\text { Range } \\
\text { of } \\
\text { Values }\end{array}$ & $\begin{array}{l}\text { Weight } \\
\text { Mean/ } \\
\text { Standard } \\
\text { Error }\end{array}$ & $\begin{array}{c}\text { Evaluated } \\
\text { Data } \\
\text { Result }\end{array}$ & $\begin{array}{l}\text { Projected } \\
\text { Inventory }\end{array}$ \\
\hline SVOA & & $\mu \mathrm{g} / \mathrm{kg}$ & $\mu \mathrm{g} / \mathrm{kg}$ & $\mu \mathrm{g} / \mathrm{kg}$ & $\mu \mathrm{g} / \mathrm{kg}$ & $\mathrm{kg}$ \\
\hline \multirow{3}{*}{$\begin{array}{c}\text { GC/MS. } \\
\text { Dodecane }\end{array}$} & Sample 92-08307 & $(8.60 E+05)$ & \multirow{3}{*}{$\begin{array}{c}6.40 E+05 \\
\text { to } \\
8.60 E+05\end{array}$} & \multirow[t]{3}{*}{$7.69 E+05$} & \multirow[t]{3}{*}{--} & \multirow[t]{3}{*}{792} \\
\hline & Sample 92-08309 & $(6.40 E+05)$ & & & & \\
\hline & Sample 92-08311 & $(7.15 E+05)$ & & & & \\
\hline
\end{tabular}


Table A-6. Tank 241-C-110 Analytical Data: Tridecane

\begin{tabular}{|c|c|c|c|c|c|c|}
\hline $\begin{array}{cc} & \text { Analyte } \\
& \ddots \\
\cdots & \therefore \\
\end{array}$ & $\begin{array}{c}\text { Laboratory } \\
\text { Sample } \\
\text { Adentification }\end{array}$ & \begin{tabular}{l} 
Analytical \\
Data \\
\hdashline Result \\
\hdashline$\quad$ Re \\
\end{tabular} & $\begin{array}{l}\text { Range } \\
\because \text { of } \\
\text { Values } \\
\therefore\end{array}$ & $\begin{array}{l}\text { Weighted } \\
\text { Mean/ } \\
\text { Standard } \\
\therefore \text { Error }\end{array}$ & $\begin{array}{c}\text { Evaluated } \\
\text { Data } \\
\text { Result }\end{array}$ & $\begin{array}{c}\text { Projected } \\
\text { Inventory } \\
\ldots \quad \\
\end{array}$ \\
\hline SVOA (Liquid) & & $\mu \mathrm{g} / \mathrm{kg}$ & $\mu \mathrm{g} / \mathrm{kg}$ & $\mu \mathrm{g} / \mathrm{kg}$ & $\mu \mathrm{g} / \mathrm{kg}$ & $\mathrm{kg}$ \\
\hline $\begin{array}{l}\text { GC/MS. } \\
\text { Tridecane }\end{array}$ & Sample 92-09437 & $(9,500)$ & N/A & - & 9.500 & 0.275 \\
\hline SVOA (Solid) & & $\mu \mathrm{g} / \mathrm{kg}$ & $\mu \mathrm{g} / \mathrm{kg}$ & $\mu \mathrm{g} / \mathrm{kg}$ & $\mu \mathbf{g} / \mathbf{k g}$ & kg \\
\hline \multirow{5}{*}{$\begin{array}{l}\text { GC/MS. } \\
\text { Tridecane }\end{array}$} & Sample 92-08303 & $(8,400)$ & \multirow{5}{*}{$\begin{array}{c}8,400 \\
\text { to } \\
1.95 E+06\end{array}$} & \multirow[t]{5}{*}{$1.15 E+06$} & \multirow[t]{5}{*}{-} & \multirow[t]{5}{*}{1,180} \\
\hline & Sample 92-08305 & $(9,350)$ & & & & \\
\hline & Sample 92-08307 & $(1.95 E+06)$ & & & & \\
\hline & Sample 92-08309 & $(1.40 E+06)$ & & & & \\
\hline & Sample 92-08311 & $(1.55 E+06)$ & & & & \\
\hline
\end{tabular}

Table A-6. Tank 241-C-110 Analytical Data: Tetradecane

\begin{tabular}{|c|c|c|c|c|c|c|}
\hline Analyte & $\begin{array}{l}\text { Laboratory } \\
\text { Sample } \\
\text { Identification }\end{array}$ & $\begin{array}{c}\text { Analytical } \\
\text { Data } \\
\text { Result }\end{array}$ & $\begin{array}{c}\text { Range } \\
\text { of } \\
\text { Values }\end{array}$ & $\begin{array}{c}\text { Weighted } \\
\text { Mean/ } \\
\text { Standard } \\
\text { Error }\end{array}$ & $\begin{array}{c}\text { Evaluated } \\
\text { Data } \\
\text { Result }\end{array}$ & $\begin{array}{l}\text { Projected } \\
\text { Inventory }\end{array}$ \\
\hline SVOA (Liquid) & & $\mu \mathrm{g} / \mathrm{kg}$ & $\mu \mathrm{g} / \mathrm{kg}$ & $\mu \mathrm{g} / \mathrm{kg}$ & $\mu \mathrm{g} / \mathrm{kg}$ & $\mathrm{kg}$ \\
\hline $\begin{array}{l}\text { GC/MS. } \\
\text { Tetradecane }\end{array}$ & Sample 92-09437 & $(11,000)$ & N/A & - & 11,000 & 0.318 \\
\hline SVOA (Solid) & & $\mu \mathrm{g} / \mathrm{kg}$ & $\mu \mathrm{g} / \mathrm{kg}$ & $\mu \mathrm{g} / \mathrm{kg}$ & $\mu \mathrm{g} / \mathrm{kg}$ & $\mathrm{kg}$ \\
\hline \multirow{4}{*}{$\begin{array}{l}\text { GC/MS. } \\
\text { Tetradecane }\end{array}$} & Sample 92-08305 & $(9,000)$ & \multirow{4}{*}{$\begin{array}{c}9,000 \\
\text { to } \\
1.45 E+06\end{array}$} & \multirow[t]{4}{*}{$7.28 E+05$} & \multirow[t]{4}{*}{-} & \multirow[t]{4}{*}{750} \\
\hline & Sample 92-08307 & $(1.45 E+06)$ & & & & \\
\hline & Sample 92-08309 & $(1.04 E+06)$ & & & & \\
\hline & Sample $92-08311$ & $(1.15 E+06)$ & & & & \\
\hline
\end{tabular}


Table A-6. Tank 241-C-110 Analytical Data: Pentadecane

\begin{tabular}{|c|c|c|c|c|c|c|}
\hline Analyte & $\begin{array}{c}\text { Laboratory } \\
\text { Sample } \\
\text { Identification }\end{array}$ & $\begin{array}{cc}\text { Analytical } \\
\text { Data } \\
\text { Result }\end{array}$ & $\begin{array}{l}\text { Range } \\
\text { of } \\
\text { Values }\end{array}$ & $\begin{array}{l}\text { Weighted } \\
\text { Mean/ } \\
\text { Standard } \\
\text { Error }\end{array}$ & $\begin{array}{c}\text { Evaluated } \\
\text { Data } \\
\text { Result }\end{array}$ & $\begin{array}{l}\text { Projected } \\
\text { Inventory }\end{array}$ \\
\hline SVOA & & $\mu \mathrm{g} / \mathrm{kg}$ & $\mu \mathrm{g} / \mathrm{kg}$ & $\mu \mathrm{g} / \mathrm{kg}$ & $\mu \mathrm{g} / \mathrm{kg}$ & $\mathrm{kg}$ \\
\hline \multirow{3}{*}{$\begin{array}{r}\text { GC/MS. } \\
\text { Pentadecane }\end{array}$} & Sample 92-08307 & $(62,500)$ & \multirow{3}{*}{$\begin{array}{c}47,500 \\
\text { to } \\
62,500\end{array}$} & \multirow[t]{3}{*}{51,500} & \multirow[t]{3}{*}{$\ldots$} & \multirow[t]{3}{*}{53.0} \\
\hline & Sample 92-08309 & $(47,500)$ & & & & \\
\hline & Sample 92-08311 & $(55,500)$ & & & & \\
\hline
\end{tabular}

Table A-6. Tank 241-C-110 Analytical Data: Phosphoric acid tributyl ester

\begin{tabular}{|c|c|c|c|c|c|c|}
\hline Analyte & $\begin{array}{l}\text { Laboratory Sample } \\
\text { Identification }\end{array}$ & $\begin{array}{c}\text { Analytical Data } \\
\text { Result }\end{array}$ & $\begin{array}{c}\text { Range } \\
\text { of } \\
\text { Values }\end{array}$ & $\begin{array}{l}\text { Weighted } \\
\text { Mean/ } \\
\text { Standard } \\
\text { Error }\end{array}$ & $\begin{array}{c}\text { Evaluated } \\
\text { Data } \\
\text { Result }\end{array}$ & $\begin{array}{l}\text { Projected } \\
\text { Inventory }\end{array}$ \\
\hline SVOA & & $\mu \mathrm{g} / \mathrm{kg}$ & $\mu \mathrm{g} / \mathrm{kg}$ & $\mu \mathrm{g} / \mathrm{kg}$ & $\mu \mathbf{g} / \mathbf{k g}$ & $\mathrm{kg}$ \\
\hline \multirow{5}{*}{$\begin{array}{l}\text { GC/MS. } \\
\text { Phosphoric acid } \\
\text { tributyl ester }\end{array}$} & Sample 92-08303 & $(8,100)$ & \multirow{5}{*}{$\begin{array}{c}8,100 \\
\text { to } \\
39,500\end{array}$} & \multirow[t]{2}{*}{14,400} & \multirow[t]{5}{*}{--} & \multirow[t]{5}{*}{14.8} \\
\hline & Sample 92-08305 & $(39,500)$ & & & & \\
\hline & Sample $92-08307$ & $(8,350)$ & & \multirow[t]{3}{*}{8,260} & & \\
\hline & Sample 92-08309 & $(12,000)$ & & & & \\
\hline & Sample 92-08311 & $(10,000)$ & & & & \\
\hline
\end{tabular}


WHC-SD-WM-ER-367 REV O

APPENDIX B

HISTORICAL INVENTORY ESTIMATES COMPARISON 


\section{B.1 TRAC Model Estimates}

The Track Radioactive Constituents (TRAC) computer program was developed to estimate the composition of the wastes in single-shell tanks (SSTs). The TRAC program estimates waste inventories based on nuclear fuels production models, reprocessing and waste management flowsheets, tank transfers, and radioactive decay calculations. The output consists of the approximate inventories of 65 radionuclides and 30 nonradioactive chemical constituents in each of the 149 SSTs. Validation of the codes used in the TRAC Model has not been performed. For this reason, the conclusions and model outputs should be regarded as approximations at best, and only used for informational purposes. A detailed description of the TRAC system can be found in TRAC: Preliminary Estimation of the Waste Inventories in Hanford Tanks Through 1980 (Jungfleisch, 1984).

The TRAC Model estimates for Tank 241:C-110 are presented in Table B-1. Although TRAC includes the concentrations of almost 100 waste constituents, Table B-1 contains only those radionuclides for which analyses are performed regularly or those with an activity greater than $1.0 \mu \mathrm{Ci} / \mathrm{L}$. The TRAC estimates are for 1980; the shorter lived radionuclides will have decayed significantly, if not completely, from the TRAC estimates; the volume of waste in the tank has also changed. In the absence of more conclusive or higher quality data, the results and estimates of the TRAC model are used as a preliminary approximation for expected tank contents and inventory.

Table B-1. TRAC Model Estimates (Jungfleisch, 1984).

TRAC Waste Volume (Total): 211,000 gallons

Estimated Waste Density: $1.8 \mathrm{~g} / \mathrm{L}$

\begin{tabular}{|c|c|c|c|c|c|}
\hline \multirow{2}{*}{$\begin{array}{l}\text { Element/ } \\
\text { Isotope }\end{array}$} & \multicolumn{2}{|c|}{ Inventory } & \multicolumn{3}{|c|}{ Concentration } \\
\hline & Moles & Curies & $g / L$ & $\mu \mathrm{Ci} / \mathrm{L}$ & ppm \\
\hline Am-241 & 2.OE-O2 & $2.0 E+01$ & & $2.50 E+01$ & \\
\hline Cs-137 & 1.OE-10 & 2.OE-06 & & 2.50E-06 & \\
\hline Pu-238 & 3.OE-03 & $1 . \mathrm{OE}+01$ & & $1.25 E+01$ & \\
\hline Pu-239 & $8.0 E+00$ & $1.0 E+02$ & & $1.25 E+02$ & \\
\hline $\mathrm{Pu}-240$ & 5.0E-01 & $3.0 E+01$ & & $3.75 E+01$ & \\
\hline Pu-241 & 1.OE-O2 & $3.0 E+02$ & & $3.75 E+02$ & \\
\hline $\mathrm{Sm}-151$ & 9.0E-O2 & $3.0 E+02$ & & $3.75 E+02$ & \\
\hline Sr-90 & $1.0 E+O 0$ & $1.0 E+04$ & & $1.25 E+04$ & \\
\hline Tc-99 & $2.0 E-10$ & $3.0 E-10$ & & $3.75 \mathrm{E}-10$ & \\
\hline$U-233$ & 8.OE-09 & 2.0E-08 & & 2.50E-08 & \\
\hline $\mathrm{U}-234$ & 4.OE-04 & 5.0E-04 & & $6.26 \mathrm{E}-04$ & \\
\hline U-235 & $1.0 E+01$ & $6.0 \mathrm{E}-03$ & & 7.51E-03 & \\
\hline U-238 & $2.0 E+03$ & 1.OE-01 & & $1.25 \mathrm{E}-01$ & \\
\hline
\end{tabular}


Table B-1. TRAC Model Estimates (Jungfleisch, 1984).

TRAC Waste Volume (Total): 211,000 gallons

Estimated Waste Density: $1.8 \mathrm{~g} / \mathrm{L}$

\begin{tabular}{|c|c|c|c|c|c|}
\hline \multirow{2}{*}{$\begin{array}{l}\text { Element/ } \\
\text { Isotope }\end{array}$} & \multicolumn{2}{|c|}{ Inventory } & \multicolumn{3}{|c|}{ Concentration } \\
\hline & Moles & Curies & $g / L$ & $\mu \mathrm{Ci} / \mathrm{L}$ & ppm \\
\hline Y-90 & $3.0 \mathrm{E}-04$ & $2.0 E+04$ & & $2.50 E+04$ & \\
\hline$Z r-93$ & $3.0 E+00$ & $8.0 \mathrm{E}-01$ & & $1.00 E+00$ & \\
\hline $\mathrm{Ag}$ & $3.0 E-17$ & & $4.05 \mathrm{E}-21$ & & $2.25 E-18$ \\
\hline $\mathrm{Al}$ & $8.0 E+02$ & & $2.70 \mathrm{E}-02$ & & $1.50 E+01$ \\
\hline $\mathrm{Ba}$ & $6.0 \mathrm{E}-01$ & & $1.03 \mathrm{E}-04$ & & $2.72 \mathrm{E}-02$ \\
\hline $\mathrm{Bi}$ & $7.0 E+04$ & & $1.83 E+01$ & & $1.02 E+04$ \\
\hline $\mathrm{C}_{2} \mathrm{H}_{3} \mathrm{O}_{3}$ & $0.0 E+00$ & & $0.00 E+00$ & & $0.00 E+00$ \\
\hline $\mathrm{C}_{6} \mathrm{H}_{5} \mathrm{O}_{7}$ & $0.0 E+00$ & & $0.00 E+00$ & & $0.00 E+00$ \\
\hline $\mathrm{CO}_{3}$ & 4.0E-05 & & 3.00E-09 & & $1.67 \mathrm{E}-06$ \\
\hline $\mathrm{Ca}$ & $4.0 \mathrm{E}-14$ & & $2.01 E-18$ & & $1.17 \mathrm{E}-15$ \\
\hline $\mathrm{Ce}$ & $1.0 \mathrm{E}-08$ & & $1.75 \mathrm{E}-12$ & & $9.72 \mathrm{E}-10$ \\
\hline $\mathrm{Cl}$ & $1.0 \mathrm{E}-14$ & & 4.44E-19 & & $2.47 \mathrm{E}-16$ \\
\hline $\mathrm{Cr}$ & $1.0 E+04$ & & $6.51 \mathrm{E}-01$ & & $3.62 E+02$ \\
\hline EDTA & $0.0 \mathrm{E}+00$ & & $0.00 E+00$ & & $0.00 E+00$ \\
\hline$F$ & $4.0 E-05$ & & $9.51 E-10$ & & $5.28 \mathrm{E}-07$ \\
\hline $\mathrm{Fe}$ & $2.0 E+05$ & & $1.40 E+01$ & & $7.78 E+03$ \\
\hline $\mathrm{Fe}(\mathrm{CN})_{6}$ & 1.0E-08 & & 2.65E-12 & & $1.47 \mathrm{E}-09$ \\
\hline HEDTA & $0.0 E+00$ & & $0.00 E+00$ & & $0.00 E+00$ \\
\hline$K$ & 2.0E-08 & & $9.79 E-13$ & & $5.44 \mathrm{E}-10$ \\
\hline La & $0.0 E+00$ & & $0.00 E+00$ & & $0.00 E+00$ \\
\hline $\mathrm{Mn}$ & $0.0 E+00$ & & $0.00 E+00$ & & $0.00 E+00$ \\
\hline $\mathrm{NO}_{2}$ & $1.0 \mathrm{E}-05$ & & $5.76 \mathrm{E}-10$ & & $3.20 \mathrm{E}-07$ \\
\hline $\mathrm{NO}_{3}$ & $2.0 \mathrm{E}-04$ & & $1.55 \mathrm{E}-08$ & & $8.61 \mathrm{E}-06$ \\
\hline $\mathrm{Na}$ & $8.0 E+01$ & & 2.30E-03 & & $1.28 \mathrm{E}+00$ \\
\hline $\mathrm{Ni}$ & $2.0 \mathrm{E}-11$ & & $1.47 \mathrm{E}-15$ & & $8.17 E-13$ \\
\hline $\mathrm{OH}$ & $6.0 E+05$ & & $1.28 \mathrm{E}+01$ & & $7.11 E+03$ \\
\hline $\mathrm{PO}_{4}$ & $7.0 E+04$ & & $8.32 E+00$ & & $4.62 E+03$ \\
\hline $\mathrm{Pb}$ & $3.0 \mathrm{E}-11$ & & $7.78 \mathrm{E}-15$ & & 4. $32 \mathrm{E}-12$ \\
\hline
\end{tabular}


Table B-1. TRAC Model Estimates (Jungfleisch, 1984).

TRAC Waste Volume (Total): 211,000 gallons

Estimated Waste Density: $1.8 \mathrm{~g} / \mathrm{L}$

\begin{tabular}{||l|l|l|l|c|c|}
\hline \multirow{2}{*}{$\begin{array}{c}\text { Element/ } \\
\text { Isotope }\end{array}$} & \multicolumn{2}{c|}{ Inventory } & \multicolumn{3}{c|}{ Concentration } \\
\cline { 2 - 6 } & Mules & Curies & g/L & $\mu \mathrm{Ci} / \mathrm{L}$ & ppm \\
\hline $\mathrm{Pu}$ & $8.0 \mathrm{E}+00$ & & $2.39 \mathrm{E}-03$ & & $1.33 \mathrm{E}+00$ \\
\hline $\mathrm{SiO}_{3}$ & $1.0 \mathrm{E}-06$ & & $9.52 \mathrm{E}-11$ & & $5.29 \mathrm{E}-08$ \\
\hline $\mathrm{SO}_{4}$ & $6.0 \mathrm{E}-01$ & & $7.22 \mathrm{E}-05$ & & $4.01 \mathrm{E}-02$ \\
\hline $\mathrm{Sr}$ & $8.0 \mathrm{E}-08$ & & $8.77 \mathrm{E}-12$ & & $4.87 \mathrm{E}-09$ \\
\hline $\mathrm{U}$ (total) & $2.0 \mathrm{E}+03$ & & $5.96 \mathrm{E}-01$ & & $3.31 \mathrm{E}+02$ \\
\hline $\mathrm{ZrO}$ & $2.0 \mathrm{E}+04$ & & $2.68 \mathrm{E}+00$ & & $1.49 \mathrm{E}+03$ \\
\hline
\end{tabular}

\section{B-2. Previous Sampling Results}

The contents of Tank $241-\mathrm{C}-110$ have been sampled in the past to support different characterization needs. The resulting analytical results are summarized in Table B-2. Two of the samples analyzed were tank liquids; the third sample was from the tank sludge. The level of validation, if any, that these results have received is not known, so this data is presented for informational purposes only.

Liquid samples, T-5491 (from 1975) and R8087 (from 1990), contain high concentrations of the soluble waste constituents. Both liquid samples were between $75 \%$ and $85 \%$ water, which indicated that quantities of suspended solids were also analyzed. As is to be expected from the liquid samples, R8087 contained substantial amounts of the soluble anions, including nitrates, nitrites, phosphates, sulfates, and carbonates. The majority of the activity from both liquid samples came from ${ }^{137} \mathrm{Cs}$.

Tank sludge sample \#9501, collected in 1977, was primarily analyzed for metals. The predominant constituent from these analyses was aluminum; silicon and iron were also represented. According to these results, plutonium is present in Tank 241-C-110 waste at a level of approximately five to 10 parts per million (ppm), and uranium is present at approximately $1 \mathrm{ppm}$. 
Table B-2. Analytical Results of Single-Shell Tank 241-C-110 Samples. (2 pages)

\begin{tabular}{|c|c|c|c|}
\hline Sample Number & $T-5491$ & 9501 - JS-17 & $\mathrm{R} 8087$ \\
\hline $\begin{array}{l}\text { Sample Information } \\
\text { Source }\end{array}$ & Wheeler, 1975 & Starr, 1977 & Edrington, 1991 \\
\hline Sampling Date & June 19, 1975 & August 31,1977 & November 1990 \\
\hline Type of Sample & Liquid & Sludge & Supernatant \\
\hline Sample Preparation & N/A & $\mathrm{KOH}$ Fusion & N/A \\
\hline ANALYSIS & \multicolumn{3}{|c|}{ SAMPLE RESULTS } \\
\hline$\%$ Water & $83.36 \%$ & & $75 \%$ \\
\hline $\mathrm{pH}$ & 11.8 & & 10.2 \\
\hline Specific Gravity & 1.134 & & 1.20 \\
\hline $\begin{array}{l}\text { Total Organic } \\
\text { Carbon }\end{array}$ & & & $0.632 \mathrm{~g} / \mathrm{L}$ \\
\hline D.T.A & $\begin{array}{l}\text { No exotherm below } \\
200 \circ \mathrm{C}\end{array}$ & & \\
\hline \multicolumn{4}{|c|}{ ANIONS } \\
\hline $\mathrm{OH}-$ & $0.831 \mathrm{~mol} / \mathrm{L}$ & & $0.489 \mathrm{~mol} / \mathrm{L}$ \\
\hline $\mathrm{NO}_{2}$ & $32,700 \mathrm{p}[\mathrm{pm}$ & NR & $22,620 \mathrm{ppm}$ \\
\hline $\mathrm{NO}_{3}$ & $29,600 \mathrm{ppm}$ & NR & $135,400 \mathrm{ppm}$ \\
\hline $\mathrm{CO}_{3}$ & & & $0.252 \mathrm{~mol} / \mathrm{L}$ \\
\hline $\mathrm{SO}_{4}$ & & NR & $20,960 \mathrm{ppm}$ \\
\hline $\mathrm{PO}_{4}$ & & NR & $8,822 \mathrm{ppm}$ \\
\hline \multicolumn{4}{|c|}{ CATIONS* } \\
\hline $\mathrm{Ag}$ & & & $6 \mathrm{ppm}$ \\
\hline $\mathrm{Al}$ & $911 \mathrm{ppm}$ & $164,000 \mathrm{ppm}$ & $36 \mathrm{ppm}$ \\
\hline As & & & $0.4 \mathrm{ppm}$ \\
\hline B & & & $21 \mathrm{ppm}$ \\
\hline $\mathrm{Ba}$ & & 800 ppm & \\
\hline $\mathrm{Bi}$ & & & $21 \mathrm{ppm}$ \\
\hline $\mathrm{Ca}$ & & $2,000 \mathrm{ppm}$ & $2 \mathrm{ppm}$ \\
\hline $\mathrm{Cd}$ & & $<260 \mathrm{ppm}$ & \\
\hline $\mathrm{Ce}$ & & & $35 \mathrm{ppm}$ \\
\hline $\mathrm{Cr}$ & & 867 ppm & $369 \mathrm{ppm}$ \\
\hline $\mathrm{Fe}$ & & $21,000 \mathrm{ppm}$ & $3 \mathrm{ppm}$ \\
\hline
\end{tabular}


Table B-2. Analytical Results of Single-Shell Tank 241-C-110 Samples. (2 pages)

\begin{tabular}{|c|c|c|c|c|}
\hline \multicolumn{5}{|c|}{ CATIONS ${ }^{*}$ (cont.) } \\
\hline \multicolumn{2}{|l|}{$\mathrm{Hg}$} & & $14,000 \mathrm{ppm}$ & $0.875 \mathrm{ppm}$ \\
\hline \multicolumn{2}{|l|}{ K } & & & $1,140 \mathrm{ppm}$ \\
\hline \multicolumn{2}{|l|}{$\mathrm{Mg}$} & & $810 \mathrm{ppm}$ & $2 \mathrm{ppm}$ \\
\hline \multicolumn{2}{|l|}{$\mathrm{Mn}$} & & $610 \mathrm{ppm}$ & $0.4 \mathrm{ppm}$ \\
\hline \multicolumn{2}{|l|}{ Mo } & & & 25 ppm \\
\hline \multicolumn{2}{|l|}{$\mathrm{Na}$} & & & $83,900 \mathrm{ppm}$ \\
\hline \multicolumn{2}{|l|}{$\mathrm{Ni}$} & & $2,000 \mathrm{ppm}$ & \\
\hline \multicolumn{2}{|l|}{$\mathrm{Se}$} & & & $0.2 \mathrm{ppm}$ \\
\hline \multicolumn{2}{|l|}{ Si } & & $15,000 \mathrm{ppm}$ & $30 \mathrm{ppm}$ \\
\hline \multicolumn{2}{|l|}{$\mathrm{Sr}$} & & & $1 \mathrm{ppm}$ \\
\hline \multicolumn{2}{|l|}{$\mathrm{Zr}$} & & & $6 \mathrm{ppm}$ \\
\hline \multicolumn{2}{|l|}{$\mathrm{Pu}$} & & $0.69 \mathrm{ppm}$ & \\
\hline \multicolumn{2}{|l|}{ U } & & $0.075 \mathrm{ppm}$ & \\
\hline \multicolumn{5}{|c|}{ RADIOCHEMISTRY } \\
\hline \multicolumn{2}{|c|}{ Total Alpha } & & NR & $55.6 \mu \mathrm{Ci} / \mathrm{L}$ \\
\hline \multicolumn{2}{|c|}{ Total Beta } & & & $35,550 \mu \mathrm{Ci} / \mathrm{L}$ \\
\hline GEA & $\begin{array}{l}\text { Cs-134 } \\
\text { Cs-137 }\end{array}$ & $\begin{array}{l}14.99 \mu \mathrm{Ci} / \mathrm{L} \\
84,500 \mu \mathrm{Ci} / \mathrm{L}\end{array}$ & $140,000 \mu \mathrm{Ci} / \mathrm{L}$ & $24,300 \mu \mathrm{Ci} / \mathrm{L}$ \\
\hline \multicolumn{2}{|c|}{ Sr-89/90 } & $8.7 \mu \mathrm{Ci} / \mathrm{L}$ & $49,000 \mu \mathrm{Ci} / \mathrm{L}$ & $8.38 \mu \mathrm{Ci} / \mathrm{L}$ \\
\hline \multicolumn{2}{|c|}{ Tc-99 } & & & $70.13 \mu \mathrm{Ci} / \mathrm{L}$ \\
\hline \multicolumn{2}{|c|}{$\mathrm{Pu} 239 / 240$} & & & $44 \mu \mathrm{Ci} / \mathrm{L}$ \\
\hline \multicolumn{2}{|c|}{ Am-241 } & & & ND \\
\hline $\begin{array}{l}\text { N/A } \\
\text { ppm } \\
\text { NR } \\
\text { GEA } \\
\text { ND }\end{array}$ & $\begin{array}{l}\text { Sludge d } \\
\text { (Jungfleis } \\
\text { Not Appl } \\
\text { parts per } \\
\text { Not Relia } \\
\text { Gamma } \\
\text { Not Dete }\end{array}$ & $\begin{array}{l}\text { f } 1.8 \mathrm{~g} / \mathrm{ml} \text { used } \\
\text { 4) Not Available } \\
\text { Analysis }\end{array}$ & nsistency with TR & Model \\
\hline
\end{tabular}


WHC-SD-WM-ER-367 REV O

\section{APPENDIX C}

THE ANOVA MODEL

(Remund and Jensen, 1984) 
C.1 The ANOVA Model (Remund and Jensen, 1984)

This appendix contains a description of the statistical model that describes the structure of the data from supernate samples taken from Tank 241-102-AP. Equations are also presented for estimates of the mean concentration, the variance for the mean concentration, and the confidence intervals on the mean concentration.

The statistical model that describes the structure of the data is

$$
y_{i j k}=\mu+L_{i}+B_{i j}+A_{i j k} ; i=1, \ldots a, j=1, \ldots b_{i}, k=1, \ldots n_{i j},
$$

Where

$$
\begin{aligned}
& y_{i j k}=\text { laboratory results from the } k^{\text {th }} \text { duplicate of the } j^{\text {th }} \text { bottle } \\
& \text { of the } j^{\text {th }} \text { location in the tank, } \\
& \mu \quad=\quad \text { the grand mean of all the data, } \\
& L_{i}=\text { the effect of the } i^{\text {th }} \text { location (measuring spatial } \\
& \text { variability), } \\
& B_{i j}=\text { the effect of the } j^{\text {th }} \text { bottle at the } i^{\text {th }} \text { location (measuring } \\
& \text { local sampling variability), and } \\
& A_{i j k}=\text { the analytical error associated with the } k^{\text {th }} \text { duplicate in } \\
& \text { the } j^{\text {th }} \text { bottle in the } i^{\text {th }} \text { location. }
\end{aligned}
$$

For the inorganic and radiological analytes, there are generally only three tank locations that have duplicate bottles and all others locations have one bottle (i.e., $b_{j}=1$ or 2 ). Reruns of the samples and duplicates (within each bottle) were obtained for some of the locations (i.e., $n_{i j}=2,4$ or 6 ).

$L_{i}$ and $B_{i j}$ are treated as random effects. It is assumed that $L_{i}, B_{i j}$ and $A_{i j k}$ are each distributed normally with mean zero and a variances $\sigma_{L}^{2}, \sigma_{B}^{2}$, and $\sigma_{A}^{2}$, respectively. Estimates of $\sigma_{L}^{2}, \sigma_{B}^{2}$, and $\sigma_{A}^{2}$ were obtained using Restricted Maximum Likelihood Estimation (REML). This method applied to variance component estimation is described by Harville (1977).

The mean concentration of each analyte of interest in the tank was calculated using the following equation:

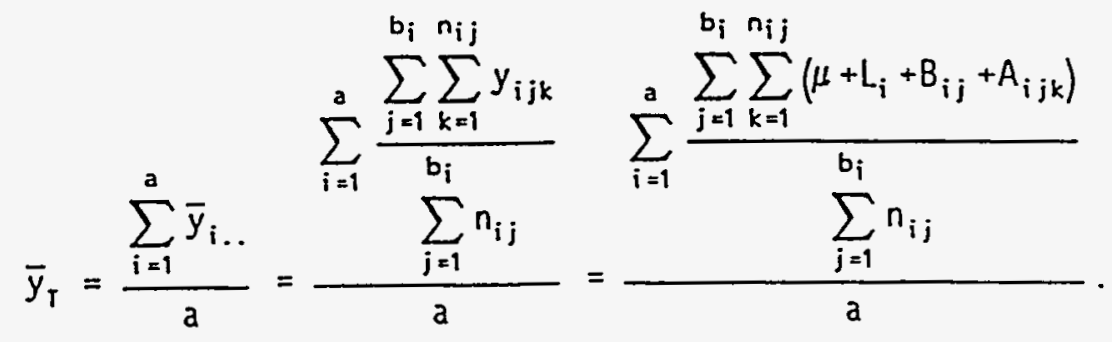


The ANOVA Model (con't)

The variance of $\bar{y}_{\mathrm{T}}$ is

$$
V\left(\bar{y}_{T}\right)=C_{1} \sigma_{L}^{2}+C_{2} \sigma_{B}^{2}+C_{3} \sigma_{A}^{2}
$$

where

$$
\left.c_{1}=\frac{1}{a}, \quad c_{2}=\sum_{i=1}^{a} \frac{\left[\sum_{j=1}^{b_{i}} n_{i j}^{2}\right.}{\left[\sum_{j=1}^{b_{i}} n_{i j}\right]^{2}}\right]^{2}, \quad c_{3}=\sum_{i=1}^{a} \frac{\left(\left[\sum_{j=1}^{b_{i}} n_{i j} n_{i j}\right]^{2}\right.}{a^{2}}
$$

Using $\hat{\sigma}_{L}^{2}, \hat{\sigma}_{B}^{2}$, and $\hat{\sigma}_{A}^{2}$ (REML variance component estimates), an estimated variance of $\bar{y}_{T}$ is

$$
\dot{\sigma}^{2}\left(\vec{y}_{T}\right)=C_{1} \dot{\sigma}_{L}^{2}+C_{2} \hat{\sigma}_{B}^{2}+C_{3} \dot{\sigma}_{A}^{2}
$$

The approximate degrees of freedom used for $\hat{\sigma}^{2}\left(\bar{y}_{T}\right)$ is the number of locations sampled minus one (which varies for each analyte).

A $95 \%$. two-sided confidence interval on the mean concentration $\left(\bar{y}_{T}\right)$ for a given analyte is

$$
\bar{y}_{T} \pm t_{.975} \sqrt{\hat{\sigma}^{2}\left(\bar{y}_{T}\right)}
$$

where $t .975$ is the .975 quantile from a Student's t-distribution with the approximate degrees of freedom associated with $\hat{\sigma}^{2}\left(\bar{y}_{T}\right)$.

A $95 \%$ upper-tailed confidence interval on $\bar{y}_{T}$ is

$$
\bar{y}_{T}+t_{.95} \sqrt{\tilde{\sigma}^{2}\left(\bar{y}_{T}\right)}
$$

where $t_{.95}$ is the .95 quantile from a Student's $t$-distribution with the approximate degrees of freedom associated with $\hat{\sigma}^{2}\left(\bar{y}_{T}\right)$. 